Tomasz KRZYżowski

(D) https://orcid.org/0000-0001-7193-5661

Ośrodek Badań nad Kulturą Ormiańską w Polsce

Polska Akademia Umiejętności, Kraków

\title{
KORESPONDENCJA ARCYBISKUPA \\ ORMIAŃSKOKATOLICKIEGO JÓZEFA TEODOROWICZA Z PRYMASEM POLSKI KARDYNAŁEM AUGUSTEM HLONDEM Z LAT 1924-1938
}

Kardynał August Hlond (1881-1948) oraz arcybiskup Józef Teodorowicz (18641938) należą do wybitnych przedstawicieli polskiego episkopatu pierwszej połowy XX stulecia. Obdarzeni nieprzeciętnymi zdolnościami, walorami duchowymi i intelektualnymi oraz talentem organizacyjnym, brali aktywny udział w życiu publicznym, jako gorliwi pasterze i patrioci. Nawiązanie kontaktu i współpracy między obu duchownymi można datować na okres pełnienia przez ks. Augusta Hlonda funkcji administratora Górnego Śląska, choć kontakty te zintensyfikowały się z chwilą objęcia przez niego stolicy prymasowskiej w Gnieźnie.

Dobrą ilustracją wszechstronnej i wielowątkowej działalności obu hierarchów na gruncie kościelnym i państwowym, jak również intensywnej współpracy jest prezentowana niżej korespondencja. Zanim jednak przejdziemy do edycji źródła, warto przypomnieć najistotniejsze fakty z życia obu duchownych.

August Hlond urodził się 5 lipca 1881 roku w Brzęczkowicach koło Mysłowic, w rodzinie Jana i Marii z Imielów. W wieku 12 lat wyjechał do Włoch, gdzie wspólnie z bratem Ignacym rozpoczął naukę w zakładzie wychowawczym salezjanów w Turynie. W 1896 roku wstąpił do zgromadzenia św. Franciszka Salezego (salezjanów), odbył roczny nowicjat i złożył śluby wieczyste. Następnie kontynuował naukę na Uniwersytecie Gregoriańskim w Rzymie, co zostało uwieńczone w 1900 roku doktoratem z filozofii. Po powrocie z Włoch pracował jako nauczyciel i wychowawca w Zakładzie Salezjańskim w Oświęcimiu. 
Dnia 23 września 1905 roku przyjął święcenia kapłańskie z rąk biskupa Anatola Nowaka. Kontynuował pracę z młodzieżą, pełniąc funkcję kapelana Schroniska im. Księcia Aleksandra Lubomirskiego w Krakowie, a następnie przełożonego Zakładu Salezjańskiego w Przemyślu (1907-1909) i Wiedniu (1909-1916). W 1916 roku został radcą inspektoralnym rozległej salezjańskiej prowincji austro-węgierskiej, a po trzech latach objął stanowisko inspektora.

W listopadzie 1922 roku został administratorem apostolskim Górnego Śląska. Od podstaw organizował centralne struktury diecezjalne, rozpoczął budowę katedry pw. Chrystusa Króla w Katowicach oraz gmachu śląskiego seminarium duchownego w Krakowie. Dał się poznać jako gorliwy duszpasterz, animator życia religijnego, dbający o integrację powierzonych mu wiernych narodowości polskiej i niemieckiej. Organizował tzw. Śląskie Zjazdy Katolickie, których celem było rozwiązywanie aktualnych problemów lokalnego Kościoła oraz odrodzenie duchowe i moralne wiernych; powołał do życia Ligę Katolicką, Wydawnictwo św. Jacka, tygodnik „Gość Niedzielny” oraz organizacje charytatywne: Sekretariat Dobroczynności Diecezjalnej i Śląski Komitet Ratunkowy. Po erygowaniu w 1925 roku diecezji katowickiej został mianowany jej ordynariuszem. Sakrę biskupią przyjął 3 stycznia 1926 roku w Katowicach z rąk kardynała Aleksandra Kakowskiego. Jednak 24 czerwca 1926 roku został mianowany arcybiskupem gnieźnieńskim i poznańskim, a 20 czerwca 1927 roku otrzymał kapelusz kardynalski. Głównym motywem wyboru biskupa Hlonda na najwyższy urząd Kościoła w Polsce były nie tylko jego wybitne zdolności organizacyjne, ale wyraźnie odmienny - w przeciwieństwie do innych hierarchów w polskim episkopacie stosunek do polityki. Cechował go znaczący dystans, gdyż uważał, że Kościół nie powinien się identyfikować z żadną frakcją polityczną.

$\mathrm{Na}$ polu pracy administracyjnej i duszpasterskiej dokonał szeregu zmian w obu archidiecezjach, między innymi zreformował sądownictwo i studia seminaryjne oraz powołał nowe katolickie instytucje oświatowe. Jako podstawowy program swojej prymasowskiej posługi głosił hasło Polski katolickiej, w której zarówno życie prywatne obywateli, jak i państwowe miało się opierać na zasadach wiary katolickiej. Katolikom w Polsce zarzucał powierzchowność oraz brak zdolności do obrony katolickich wartości. W celu zdynamizowania życia katolickiego powołał w 1929 roku Akcję Katolicką, wspierał także rozwój badań naukowych w zakresie katolickiej nauki społecznej. W tym celu erygował Radę Społeczną (1933). Opieką duszpasterską otoczył również polskich emigrantów, powołując w tym celu w roku 1932 nowe zgromadzenie Towarzystwa Chrystusowego. Jako przywódca polskiego Episkopatu dążył do jego integracji i wspólnego działania - uważał, że najlepszym gwarantem obrony interesów Kościoła jest spójne działanie wszystkich hierarchów; w myśl zaleceń Piusa XI dążył do odpolitycznienia Kościoła.

Okres drugiej wojny światowej spędził na emigracji w Rzymie i we Francji, zabiegając o sprawy Polski. Do Poznania wrócił 20 lipca 1945 roku. Na mocy 
nadanych mu przez Piusa XII przywilejów zajął się organizacją katolickiej administracji zachodnich i północnych ziem Polski. Po połączeniu archidiecezji gnieźnieńskiej i warszawskiej w 1946 roku unią personalną stanął na czele nowej jednostki administracyjnej Kościoła. Doniosłym wydarzeniem w powojennej posłudze prymasa było uroczyste poświęcenie narodu polskiego Niepokalanemu Sercu Maryi 8 września 1946 roku na Jasnej Górze. Kardynał August Hlond zmarł 22 października 1948 roku. Został pochowany w podziemiach archikatedry pw. św. Jana w Warszawie. W 1992 roku rozpoczął się jego proces beatyfikacyjny ${ }^{1}$.

Józef Teofil Teodorowicz urodził się 25 lipca 1864 roku w Żywaczowie na Pokuciu w rodzinie Grzegorza i Gertrudy z Ohanowiczów. Po śmierci ojca rodzina przeniosła się do Stanisławowa, gdzie Józef Teodorowicz ukończył szkołę powszechną i gimnazjum. Po złożeniu egzaminu dojrzałości rozpoczął studia prawnicze w Czerniowcach na Bukowinie (1882), które przerwał po roku, wstępując na Wydział Teologiczny Uniwersytetu Lwowskiego, podejmując jednocześnie formację duchowo-ascetyczną w lwowskim seminarium duchownym (18831887). Dnia 9 stycznia 1887 roku przyjął święcenia kapłańskie z rąk ówczesnego arcybiskupa lwowskiego obrządku ormiańskiego Izaaka Isakowicza. Po święceniach kapłańskich rozpoczął pracę duszpasterską w katedrze ormiańskiej we Lwowie, następnie jako wikariusz parafii ormiańskiej w Stanisławowie i ponownie w katedrze lwowskiej. Dnia 1 maja 1890 roku został administratorem, a kilka lat później - proboszczem parafii ormiańskiej w Brzeżanach. W 1897 roku otrzymał nominację na kanonika gremialnego kapituły ormiańskiej we Lwowie. Już wtedy był postacią wybijającą się i wyróżniającą wśród duchowieństwa archidiecezji. Zasłynął jako wytrawny mówca i kaznodzieja. Obok obowiązków kapłańskich dał się poznać jako doskonały organizator i inicjator życia społeczno-kulturalnego, charytatywnego i politycznego. Był między innymi współzałożycielem i redaktorem naczelnym „Ruchu Katolickiego”, „Przedświtu” oraz Bractwa Wydawniczego św. Józefa.

Dnia 30 maja 1901 roku został wybrany przez duchowieństwo na arcybiskupa lwowskiego obrządku ormiańskiego, 2 lutego 1902 roku otrzymał sakrę biskupią z rąk kardynała Jana Puzyny oraz odbył uroczysty ingres do katedry. Rządy arcybiskupa Teodorowicza to czas rozwoju wielu inicjatyw kulturalno-oświatowych, społecznych i religijnych wśród społeczności polskich Ormian, między innymi powstanie Archidiecezjalnego Związku Ormian, Muzeum Archidiecezjalnego, Kongregacji Ziemianek w Kochawinie, druk czasopisma „Posłaniec św. Grzegorza", koronacja cudownego wizerunku Matki Bożej Łaskawej w Stanisławowie,

1 A. Słomka, Rys biograficzny kardynała A. Hlonda, w: August kardynat Hlond na straży sumienia Narodu. Wybór pism i przemówień, Warszawa 1999, s. IX-XV; K. Krasowski, Biskupi katoliccy II Rzeczypospolitej. Słownik biograficzny, Poznań 1996, s. 78-98; Kardynat August Hlond (1881-1948). Pasterz - nauczyciel - świadek, red. M. Grygiel, Poznań 2010. 
opieka nad Zakładem im. Józefa Torosiewicza we Lwowie, troska o należytą formację duchowo-intelektualną kleryków itd.

Arcybiskup Teodorowicz należał do grona najwybitniejszych i najbardziej energicznych działaczy w polskim episkopacie. Był również członkiem różnych komisji działających w jego ramach - Komisji Prawnej (od 1928), przewodniczącym Komisji Prasowej (1921-1930) i Komisji Duszpasterskiej, którą kierował (od 1928). Aktywnie włączył się również w prace Komisji Konkordatowej (19231925). Swoją działalność rozwinął także na polu życia publicznego. W schyłkowym okresie zaborów zasiadał w austriackiej Izbie Panów (1902-1918) oraz Sejmie Krajowym galicyjskim (1902-1914). Po odzyskaniu przez Polskę niepodległości piastował mandat poselski do Sejmu Ustawodawczego (1919-1922), a w następnej kadencji parlamentarnej - senatorski z listy Chrześcijańskiego Związku Jedności Narodowej (1922-1923). W działalności politycznej ormiański hierarcha związał się z Narodową Demokracją i ugrupowaniami chadeckimi. Popierał zreformowany przez Romana Dmowskiego Obóz Wielkiej Polski i działał na rzecz zjednoczenia ruchu narodowego. Był zdecydowanym przeciwnikiem Józefa Piłsudskiego i rządów sanacji.

W 1912 roku otrzymał doktorat honoris causa Wydziału Teologicznego Uniwersytetu Lwowskiego, a w 1924 roku - Order Odrodzenia Polski. Zmarł we Lwowie 4 grudnia 1938 roku i został pochowany na cmentarzu Orląt ${ }^{2}$.

Zarówno kardynał Hlond, jak i arcybiskup Teodorowicz pozostawili bogatą spuściznę pisarską, zawierającą szereg dokumentów: listów, homilii, notatek i innego rodzaju cennych materiałów. W przypadku prymasa zostały one zebrane, opracowane i zamieszczone przez ks. Stanisława Kosińskiego w wielotomowym zbiorze źródeł zatytułowanym Acta Hlondiana ${ }^{3}$ (dalej: AH). Zbiór ten jest dostępny w formie maszynopisu w kilku instytucjach, między innymi w Archiwum Salezjańskim Inspektorii Krakowskiej w Krakowie (dalej: ASIK). Z kolei materiały archiwalne po arcybiskupie Teodorowiczu zdeponowano w Archiwum Fundacji Kultury i Dziedzictwa Ormian Polskich w Warszawie (dalej: FKiDOP). Obydwie kolekcje są imponujące zarówno pod względem zasobu zgromadzonego materiału źródłowego, ale przede wszystkim ciężaru gatunkowego, dokumentując działalność tych wybitnych arcypasterzy i mężów stanu.

2 T. Krzyżowski, Archidiecezja lwowska obrządku ormiańskokatolickiego w latach 1902-1938, Kraków 2018, rozprawa doktorska napisana pod kierunkiem ks. prof. dr. hab. J. Wołczańskiego na Uniwersytecie Papieskim Jana Pawła II w Krakowie, mszps, s. 111-146; S. Gawlik, Życie i działalność ks. arcybpa Józefa T. Teodorowicza, Kraków-Warszawa-Struga 1988; R. Król-Mazur, Działalność polityczna arcybiskupa Józefa Teofila Teodorowicza w latach 1888-1923, Kraków 2013, s. 13-22.

3 Archiwum Salezjańskie Inspektorii Krakowskiej w Krakowie (dalej: ASIK), Acta Hlondiana. Materiały do życia i działalności kardynała Augusta Hlonda Prymasa Polski, oprac. S. Kosiński, Ląd nad Wartą 1966, mszps. 
Prezentowana niżej korespondencja stanowi fragment wspomnianych spuścizn archiwalnych. Listy z ASIK zostały przygotowane do druku na podstawie kopii ze zbioru Acta Hlondiana, dlatego nie dokonano weryfikacji ich treści z oryginałami, przechowywanymi w Archiwum Archidiecezji Gnieźnieńskiej w Gnieźnie. Natomiast listy z Archiwum FKiDOP zostały odczytane z oryginałów lub kopii w zespole „Spuścizna arcybpa Józefa Teodorowicza”.

Dotychczas drukiem ukazała się jedynie korespondencja arcybiskupa Teodorowicza adresowana do arcybiskupa Józefa Bilczewskiego, metropolity lwowskiego obrządku łacińskiego ${ }^{4}$. W przypadku niniejszej edycji dysponujemy listami obu hierarchów. W kolekcji zachowało się 87 listów, w tym 63 arcybiskupa Teodorowicza oraz 24 kardynała Hlonda. Z całą pewnością zbiór ten nie jest kompletny, zawiera jednak wszystkie listy przechowywane we wspomnianych instytucjach. W edycji uwzględniono również załączniki do listów, jeśli takowe się zachowały. Korespondencję zamieszczono w kolejności chronologicznej. Powstała ona na przestrzeni 14 lat; pierwszy list pochodzi z okresu, kiedy ks. Hlond pełnił funkcję administratora apostolskiego Górnego Śląska, pozostałe natomiast z okresu jego posługi prymasowskiej. Publikacja zawiera prywatną korespondencję hierarchów. Nie zostały uwzględnione listy rozsyłane przez prymasa Hlonda do wszystkich członków episkopatu.

Korespondenci poruszali wiele zagadnień. Dominują aktualne problemy Kościoła w Polsce: utworzenie Katolickiej Agencji Prasowej, prace nad organizacją zaplecza i działalność Akcji Katolickiej, prasa katolicka, uroczystości religijne, reforma szkolnictwa oraz katechizacja, problemy zgromadzenia sióstr niepokalanek, plany powrotu starokatolików do Kościoła katolickiego, a także rutynowe prace episkopatu: programy obrad, listy pasterskie, działalność poszczególnych komisji itd.

Korespondencja dostarcza również informacji o stanowiskach obu hierarchów wobec wyborów parlamentarnych oraz sytuacji politycznej w kraju. Zasadniczą cechą odróżniającą ich był bowiem stosunek do polityki. Arcybiskup Teodorowicz popierał program Narodowej Demokracji, żądał także wyrazistego stanowiska i reakcji episkopatu potępiającej niewłaściwe - jego zdaniem - posunięcia władz państwowych, zwłaszcza po roku 1926. Prymas z kolei nie identyfikował się z żadnym ugrupowaniem politycznym, dlatego do aktywności politycznej ormiańskiego hierarchy podchodził z dużą rezerwą. Zarzucał mu „ciasny horyzont polityczny", który nie pozwala na szersze spojrzenie i wyważoną ocenę, a niektóre działania uznawał za szkodliwe. Wspomniane różnice i napięcia, co zrozumiałe, utrudniały pracę episkopatu, gdyż część biskupów podzielała zdanie

4 J. Wołczański, Listy arcybiskupa Józefa Teodorowicza do arcybiskupa Józefa Bilczewskiego z lat 1900-1923, cz. 1, 1900-1901, „Przegląd Wschodni”, 8, 2003, 4, s. 977-1019; cz. 2, 1902-1913, ibidem, 9, 2004, 2, s. 379-429; cz. 3, 1914-1923, ibidem, 9, 2006, 4, s. 803-838. 
arcybiskupa Teodorowicza, a część opowiadała się za zachowawczą taktyką prymasa. Napięcia nasiliły się w 1930 roku po tzw. procesie brzeskim, kiedy arcybiskup Teodorowicz apelował do prymasa o zdecydowaną i szybką reakcję episkopatu oraz stanowcze potępienie nadużyć władzy.

Ciekawy wątek, acz bardzo bolesny dla arcybiskupa Teodorowicza, stanowi zamieszanie wywołane wydaniem jego książki pt. Zjawiska mistyczne $i$ ich ttumaczenia (Konnersreuth) ${ }^{5}$, zwłaszcza jej niemieckie tłumaczenie wydane w 1936 roku. Publikacja odbiła się szerokim echem nie tylko w Polsce, ale także w krajach Europy Zachodniej, zwłaszcza w Niemczach i Włoszech. Arcybiskup spotkał się z zarzutami niekompetencji w podejściu do badania tego typu zagadnień oraz oskarżeniami o herezję. Spowodowało to intensywną polemikę arcybiskupa z o. Pawłem Siwkiem SJ, a także wywołało reakcję Świętego Oficjum. Dzięki między innymi interwencji prymasa Hlonda u Piusa XI udało się zakończyć sprawę pomyślnym dla Teodorowicza werdyktem.

Podczas prac edytorskich zastosowano aparat naukowy właściwy publikacjom źródeł epistolograficznych. Nie ingerowano w stylistykę oraz interpunkcję, uwspółcześniono jedynie archaizmy, podając je w obecnym brzmieniu.

\section{Listy}

1.

FKiDOP, t. 140, sygn. 18/231 [7], s. 1-2, ks. August Hlond do arcybpa Józefa Teodorowicza ${ }^{6}$.

Ekscelencjo!

Najprzewielebniejszy Księże Arcybiskupie!

Proszę mi darować, że przyłączając się do prośby Komitetu przygotowującego III. Śląski Zjazd Katolicki ${ }^{7}$, śmiem i ja najuniżeniej prosić Waszą Ekscelencję o łaskawe zaszczycenie Zjazdu swą obecnością i o łaskawe wygłoszenie referatu. Jeśli kiedy, to dziś Śląsk potrzebuje ze strony Arcypasterzy polskich gorącej za-

5 Poznań 1933.

${ }^{6}$ List napisany na podwójnej nieliniowanej kartce formatu zeszytowego. Dołączono list nieznanej z nazwiska kobiety do syna, który nie został uwzględniony w niniejszej edycji.

7 Trzeci Śląski Zjazd Katolicki odbywał się w dniach od 6 do 8 września 1924 roku w Katowicach $\mathrm{z}$ inicjatywy administratora apostolskiego Augusta Hlonda. Poruszono na nim wiele aktualnych problemów Kościoła w Polsce i na Śląsku, między innymi takie, jak: ruchy sekciarskie, działalność masonerii, odrodzenie moralne katolików, działalność dobroczynna, integracja środowiska niemieckich i polskich katolików itd. A. Hlond, Odezwa w sprawie III Śląskiego Zjazdu Katolickiego, Katowice 20 VIII 1924, w: idem, Dzieła. Nauczanie 18971948, t. 1, red. J. Konieczny, Toruń 2003, s. 113-114. 
chęty, aby się nie poddawał wrażeniu, że spotkało go rozczarowanie na punkcie zdolności Monomicznej Polski, a nawet co do jej katolickości. Pan Bóg Ekscelencji tę ofiarę poniesioną dla Śląska wynagrodzi.

Z czcią najgłębszą jestem Waszej Ekscelencji powolny sługa w Chrystusie ks. August Hlond Adm[inistrator] Apost[olski]

\section{2.}

ASIK, $A H$, t. V, cz. 5, s. 64, arcybp J. Teodorowicz do arcybpa A. Hlonda ${ }^{8}$.

Najczcigodniejszy Księże Prymasie!

Jakkolwiek wiedziałem już o tym że Wasza Ekscelencja ma zostać Arcybiskupem Gnieźnieńskim, to jednak będąc za granicą nie wiedziałem długo o tym, czy też formalnie nominacja nastąpiła ${ }^{9}$. Dziś skoro wiem już, pośpieszam złożyć Księdzu Prymasowi z głębi serca najgorętsze życzenia nie tylko w interesie jednej diecezji, ale Kościoła w Polsce. Tak nam dziś potrzeba sternika i wodza, więc dzięki Bogu za to że Go nam dał w Osobie Waszej Dostojności. Będę się modlił, by Duch św. wspierał kroki Waszej Ekscelencji, nieraz z pewnością cierniste i trudne. Ale nie wątpię na chwilę o tym, że ta sympatia i to zaufanie, jakie sobie umiał zdobyć i zaskarbić Wasza Ekscelencja, dzisiaj się tylko wszerz pogłębi i wszelkie przedsięwzięcie choćby najtrudniejsze uczyni łatwym i słodkim.

Łączę z życzeniami zapewnienie o mych najoddańszych zawsze uczuciach sługa Waszej Dostojności

+ Teodorowicz

Czechy Joachimstal ${ }^{10}$ - Palasthotel 4/VII [1]926

3.

ASIK, $A H$, t. V, cz. 28, s. 7, arcybp J. Teodorowicz do arcybpa A. Hlonda ${ }^{11}$.

Wasza Ekscelencjo!

Najprzewielebniejszy Księże Prymasie!

Zaproszenie otrzymałem i na niedzielę $17 \mathrm{go}$ przybędę do Poznania. Prawdopodobnie po mowie w Krakowie w piątek udam się do Poznania zaraz w pią-

${ }^{8}$ Mszps pisany na 1 stronie formatu A4.

9 Nominację papieską na arcybiskupa gnieźnieńskiego i poznańskiego biskup August Hlond otrzymał 24 czerwca 1926 roku.

10 Jachymov (niem. Joachimsthal) - miejscowość turystyczno-wypoczynkowa w północno-zachodnich Czechach (wtedy: Czechosłowacji).

${ }_{11}$ Mszps pisany na 1 stronie formatu A4. 
tek wieczór. Wobec tego, że jak mi to mówił biskup Krakowski ${ }^{12}$ życzeniem jest Waszej Ekscelencji byśmy podali tematy do narad, proponuję z mej strony następujące:

1. Co należy czynić wobec dotychczasowej metody rządu o uiszczaniu wypłat poręczonych konkordatem?

2. Dyskusja z okazji wiecu katolickiego w Warszawie, w szczególności jego postulatów co do dziennika katolickiego i organizacji ligi.

3. Agencja Katolicka ${ }^{13}$ (uchwała Konferencji ostatniej episkopatu).

4. Plany obecne masonerii i stanowisko wobec nich ${ }^{14}$.

5. Stanowisko ep[iskopatu] wobec przyszłych wyborów ${ }^{15}$.

Łączę dla Waszej Ekscelencji najoddańsze wyrazy czci głębokiej i szacunku

+ Teodorowicz

Lwów d[nia] 4/9 [1]926

[Załącznik $^{16}$ - memoriał załączony do listu bpa Anatola Nowaka ${ }^{17}$ ]

Pro memoria

Naród nasz przeżywa bardzo ciężką wewnętrzną kryzys ${ }^{18}$. Chorą jest dusza narodu.

Życie rodzinne ${ }^{19}$ rozprzęga się przez rozwody coraz liczniejsze okupywane zdradą i odstąpieniem od Boga, łamaniem wszelkich przysiąg i zobowiązań za-

12 Adam Stefan Sapieha (1867-1951) - święcenia kapłańskie otrzymał w 1893 roku we Lwowie, doktor prawa kanonicznego, wychowawca i wicerektor lwowskiego Seminarium Duchownego (1897-1901), kanonik kapituły metropolitalnej we Lwowie (1902-1911), osobisty sekretarz Piusa X w Rzymie (1906-1911), 24 listopada 1911 roku mianowany ordynariuszem diecezji krakowskiej, 14 grudnia 1925 roku - arcybiskupem metropolitą, 18 lutego 1946 roku - kreowany kardynałem. R. Prokop, Poczet biskupów krakowskich, Kraków 1999, s. 239-246.

13 Właściwie: Katolicka Agencja Prasowa - działała w latach 1927-1939, założona i kierowana przez ks. Józefa Gawlinę, a od 1929 roku przez ks. Zygmunta Kaczyńskiego. Przekazywała i popularyzowała informacje dotyczące bieżącej sytuacji Kościoła w Polsce i na świecie. Współpracowała z wieloma redakcjami w Europie, posiadała własnych korespondentów. K. Klauza, Z. Skwierczyński, Katolicka Agencja Prasowa, w: Encyklopedia katolicka (dalej: EK), 8, Lublin 2000, kol. 1082-1083.

${ }_{14}$ Zdanie podkreślone.

$15 \mathrm{JW}$.

16 ASIK, AH, t. V, cz. 28, s. 8-11. Mszps pisany na 4 stronach formatu A4.

17 Anatol Nowak (1862-1933) - święcenia kapłańskie otrzymał w 1885 roku w Krakowie, urzędnik konsystorza biskupiego tamże, kanonik kapituły katedralnej, bliski współpracownik kardynała Albina Dunajewskiego i kardynała Jana Puzyny, biskup pomocniczy krakowski (1900-1924), ordynariusz przemyski (1924-1933). K. Krasowski, Biskupi katoliccy II Rzeczypospolitej, s. 177-179.

18 Pisownia zgodna z oryginałem.

19 Wyrazy podkreślone. 
ciągniętych przez rozprzężenie życia rodzinnego rozluźniają się i węzły państwowe i zmysłowość - z nią chęć użycia podkopują obyczaj publiczny.

$\mathrm{W}$ życiu społecznym ${ }^{20}$ mamy najsmutniejsze i najboleśniejsze przejawy, które sięgają aż do wstrząśnienia samych podstaw sumienia narodowego. Poczucie odpowiedzialności za losy narodu, za zdrowie moralne ustroju społecznego słabnie, a nieraz się wprost rozluźnia, natomiast partyjność mająca przede wszystkim prywatne cele na oku, ta rośnie i ze szkodą [dla] dobra publicznego potęguje się.

Prawdziwa zasługa, która się opiera o rzetelną pracę i cnotę, i miłość ojczyzny jest nieraz pomiatana, deptana, a zaś o wartości prawdziwej nie rozstrzyga wiedza ni talent, ni cnota, tylko raczej przynależność do tego czy owego obozu.

Nie ma ni jednego elementu składowego, który by w ustroju publicznym i prawodawstwie naszym był tak uwzględnionym, jak tego istotna wymaga potrzeba.

Stąd autorytet $\mathrm{w}$ życiu publicznym słabnie albo załamuje się, praca nie odpowiada potrzebom budującego się państwa i nie wytrzymuje konkurencji ekonomicznej z państwami sąsiednimi, własność prywatna nie jest jak należy poręczona. Życie rodzinne nie jest w owej spoistości dosyć obronione, karność publiczna rozluźnia się. Następstwem tego jest, że jak w chorym organizmie chorobie towarzyszą objawy ociężałości rozdrażnienia, niesmaku, brak apetytu, tak w chorym organizmie narodowym budzi się zniechęcenie, niewiara w siły narodu, apatia w życiu publicznym, opieszałość i obojętność.

Życie religijne jest u nas zagrożone przez różne prądy tzw. teozofii, spirytyzm. Godzą one niewątpliwie w Kościół: ale godzą one nieraz wprost w państwo i są nieraz na usługach wielkiej międzynarodowej organizacji, która sypiąc znacznie pieniądzem pragnie rozstrojem naszym życie religijne zniszczyć, a przynajmniej ubić nasze życie państwowe.

Jest jeszcze inna organizacja międzynarodowa, której wielka Polska w planach jej stoi w drodze - masoneria. Działa ona w tajnych związkach do których werbuje samych polaków ${ }^{21}$ to widokami kariery, to innymi obietnicami. Nie odkrywa atoli przed nimi właściwych swoich celów, natomiast żąda od członków swoich ślepego i kategorycznego oddania się i posłuszeństwa. Działalność jej zwrócona jest przeciw Kościołowi i religii, ale także i przeciw państwu, albowiem o jego losach nie ma rozstrzygać narodowa własna myśl, ale rozum obcy, dla którego Polska i jej rozwój nie jest bynajmniej celem, rozum który się z[e] swoich planów nie potrzebuje tłumaczyć, ani ich objawiać i dlatego dzięki ukryciu działa na zgubę Polski posługując się jej synami jako niebacznymi narzędziami.

Skutki ${ }^{22}$

Wszystko to razem są objawy wysoce niepokojące, które zdradzają wewnętrzną niemoc i chorobę. Następstwem tego stanu jest, że jak w chorym organizmie

\footnotetext{
$20 \mathrm{JW}$.

21 Pisownia zgodna $z$ oryginałem.

22 Wyraz podkreślony.
} 
towarzyszą chorobie objawy rozstroju, ociężałości, braku apetytu, niesmaku, podobnie i w chorym organizmie narodowym powstaje rozstrój, apatia w życiu publicznym, załamanie się kierunków narodowych myśli, opieszałość i obojętność obok ogólnego zaniepokojenia.

Nadto, gdy w jednym choćby punkcie zostaje bezkarnie nadwyrężona jaka zasada ustroju społecznego, to się rozluźnia on cały. Gdy jedno miejsce jest chore, choruje całe ciało, cały organizm narodowy i państwowy. Niech tylko w jednym miejscu pokaże się bezprawie, a ujdzie bezkarnie, to obaczycie, że skorzystają z tego najgorsze męty społeczne, które powiedzą sobie: w Polsce wszystko wolno i za jedną bezprawnością powinie się ich tysiące, w orszaku zbrodni, morderstw, skrytobójczych zamachów, ale i na zewnątrz przedostaje się rozstrój wewnętrzny.

Choroby epidemiczne tam się przede wszystkim szerzą, gdzie organizmy ludzkie są osłabione i na wpływy zarodków choroby podatne. A sąsiadujemy przecież z ogniskiem zarazy moralnej i duchowej. Więc propaganda komunizmu skoro dopatrzy w nas miejsce w naszym organizmie państwowym nadwyrężone czy chore, zaraz z nich skorzysta dla swoich celów, zapuści w ranę wewnętrzną niezabliźnioną swój jad i pocznie coraz to bezkarniej, coraz to śmielej, a niestety coraz to skuteczniej swoje wywrotowe dzieło. Natomiast inne państwa, które by rade $\mathrm{w}$ Polsce widzieć w interesie swoim własnym ostoję porządku i ładu, to patrząc na nasz rozstrój będą się od nas odsuwać.

$\mathrm{Z}$ iluż to wrogami dzisiaj walkę stoczyć musimy! Tu komunizm, tu wpływy bolszewizmu, to obce organizacje dybiące na naszą całość i siłę, tu znowu sekty przeróżne. Wszyscy ci wrogowie umieją się łączyć z sobą i sprzymierzyć jeżeli idzie tylko o spisek na nas. Ale czy zdołamy skuteczną z nimi stoczyć walkę jeżeli sami wewnątrz zaród ciężkiej choroby mieć będziemy? Nie, przenigdy. Dlatego uleczmy wprzód samych siebie, byśmy zdrowi pod zdrowymi hasłami, na zdrowych oparci zasadach za naszą ojczyznę zastawiać się mogli. Wiedzmy i o tym, że sami sobie nie starczymy: ze siebie bowiem ani potrzebnego światła nie mamy, aby się w ciemnościach rozejrzeć, ani też potrzebnej nie posiadamy siły, ażeby złu moralnemu skutecznie się przeciwstawić.

Nie tylko dla nas, ale dla całego zagrożonego dzisiaj świata deską ratunku jest Królestwo Chrystusowe, jest Kościół i w nim rządzący Król Chrystus Jezus.

Dlatego jest to tak opatrznościowe, że dzisiejszy papież, jako ratunek światu wskazał nabożeństwo nowe do Chrystusa Króla. W Nim to i w jego Kościele jest światło świata. On drogą jest na bezdrożach on żywotem w śmierci powszechnej. W nim, w jego zasadach znajdziemy dla siebie zasady ustroju społecznego, w jego łasce znajdziemy uzdrowienie wewnętrzne, w jego Kościele ster dla naszego skołatanego i rozbitego narodowego, i państwowego życia.

Ratunek w Kościele ${ }^{23}$ : rozwinąć to.

${ }^{23}$ Wyrazy podkreślone. 
Gdy zejdziemy do szczegółów to zobaczymy, że w nierozerwalności węzła małżeńskiego, w karności moralnej, której Kościół uczy mamy sobie poręczone zasadnicze podstawy i warunki dla zdrowej rodziny, i czystych obyczajów.

Wszelki autorytet ziemski jest okolony autorytetem nadziemskim Jezusa Chrystusa. W Nim i przez Niego przysięgi państwowe żołnierza czy urzędnika, najwyższych stopni hierarchicznych jak i najniższych obowiązują nie tylko przed państwem ale i przed Bogiem w sumieniu. Gdy zachwiany zostaje wszelki autorytet w dzisiejszym świecie, ostaje się tylko jedynie ten jeden autorytet jaki jest w Chrystusie i Kościele. W zasadach Chrystusowych o własności, rodzinie, pracy są poręczone nieprzemienne wartości zdrowego ustroju społecznego.

Służba w Królestwie Bożym w Chrystusie i Kościele, i duch tej służby, jaki tkwi w wyrzeczeniu się i poświęceniu, jest zarazem antidotum na toczący nasze społeczeństwo egoizm i chęć używania. Życie nadprzyrodzone w Kościele gdy oczyszcza dusze, gdy słabych w dobrym utwierdza, daje prawdziwe oparcie dla zdrowej cywilizacji i kultury, w czystej i świętej duszy.

Nie z programów zagranicznych poddawanych nam nieszczerze przez obcych, ale w programie Chrystusa i w posterunku jaki Polska z jego woli pośród narodów zajmuje tkwi jej przewodnia myśl i program wszelkich programów. $\mathrm{Na}$ zasadzie Kościoła dokonacie jedynie zjednoczenia naszego rozbitego społeczeństwa i zespolenia ludzi dobrej woli, którzy bez względu na przynależność partyjną, bez względu na poglądy i zapatrywania połączą się w jedno.

Wezwanie do łączności i skupienia ${ }^{24}$

Ton ufności ${ }^{25}$

FKiDOP, t. 7, sygn. 1945/367 [4], s. 2, arcybp A. Hlond do arcybpa J. Teodorowicza ${ }^{26}$.

Ekscelencjo!

Poznań, dn[ia] 28.12.1926

Różne względy przemawiają za tym, żeby Episkopat uczcił godnym darem $\mathrm{J}$ [ego] Em[inencję] Ks. Pronuncjusza Lauriego ${ }^{27} \mathrm{z}$ okazji jego wyniesienia do

${ }^{24} \mathrm{JW}$.

${ }^{25} \mathrm{JW}$.

${ }^{26}$ Mszps pisany na podwójnej nieliniowanej kartce formatu A4. W lewym górnym rogu: „Prymas Polski”.

${ }^{27}$ Lorenzo Lauri (1864-1941) - święcenia kapłańskie otrzymał w 1887 roku w Rzymie, w 1917 roku mianowany arcybiskupem tytularnym Efezu, dyplomata watykański, internuncjusz i nuncjusz apostolski w Peru (1917-1921), a następnie w Polsce (1921-1926), w 1926 roku kreowany kardynałem, penitencjarz większy (1927-1941). J. Wołc zański, Listy biskupa Józefa Sebastiana Pelczara do arcybiskupa Józefa Bilczewskiego z lat 1889-1923, w: 
godności kardynalskiej. Kilku Księży Biskupów zwróciło się już do mnie z propozycją, bym się tą sprawą zajął. Takim podarunkiem mógłby być moim zdaniem pierścień, dostosowany do kosztownego pektorału, który Jego Eminencji złożył w darze w zeszłym roku Rząd Polski. Koszta tego prezentu rozłożone na wszystkich Księży Biskupów Ordynariuszów wynosiłyby mniej więcej 250 złotych na każdego.

Przewidując zgodę Waszej Ekscelencji na sprawienie takiego upominku zasłużonemu około Kościoła w Polsce Ks. Kardynałowi, poprosiłem J[ego] Em[inencję] Ks. Kardynała Kakowskiego ${ }^{28}$, by w Rzymie pierścień tej wartości nabył. Ekscelencję Waszą zaś najuprzejmiej proszę o zgodę na to kupno i o przekazanie mi podanej powyżej kwoty.

Wręczenie pierścienia odbędzie się po powrocie J[ego] Em[inencji] Ks. Kardynała Kakowskiego z Rzymu.

$\mathrm{Z}$ wyrazami najgłębszej czci

+ August Hlond ${ }^{29}$

Prymas

5.

ASIK, $A H$, t. V, cz. 5, s. 65, arcybp J. Teodorowicz do arcybpa A. Hlonda ${ }^{30}$.

Wasza Ekscelencjo!

Lwów d[nia] 15/I [1]927

W odpowiedzi na list Waszej Ekscelencji z wezwaniem mnie do składki na pierścień dla Kardynała Lauri, z przykrością wielką przychodzi mi zaznaczyć, iż z zasadniczych powodów przyłączyć się do składki nie mogę. Z listu Waszej Ekscelencji wypływa, że dar ten miałby być wyrazem zasług wielkich Nuncjusza Lauri dla Polski. W niejednym uznaję zasługi obecnego nuncjusza. $\mathrm{Z}$ wielkim też uznaniem jestem dla niego jako człowieka pracy i najlepszy intenzii ${ }^{31}$, ale o jego roli w Polsce mam wręcz odmienne zapatrywanie. Jego niechęć do rządu

Święty Józef Sebastian Pelczar (1842-1924). Rektor Uniwersytetu Jagiellońskiego i biskup przemyski, red. A. Kubiś, J. Wołczański, Kraków 2005, s. 339, przyp. 438.

28 Aleksander Kakowski (1862-1938) - święcenia kapłańskie otrzymał w 1886 roku w Warszawie, doktor prawa kanonicznego Uniwersytetu Gregoriańskiego (1885), urzędnik warszawskiego konsystorza biskupiego, wykładowca prawa kanonicznego i homiletyki w seminarium duchownym w Warszawie (1887-1898), a następnie rektor tejże uczelni (18991910), rektor Akademii Duchownej w Petersburgu (1910-1913), arcybiskup metropolita warszawski (1913-1938), kardynał prezbiter (od 1919), członek Rady Regencyjnej i Rady Stanu (1917-1918). K. Krasow ski, Biskupi katoliccy II Rzeczypospolitej, s. 112-118.

29 Własnoręczny podpis autora listu.

${ }^{30}$ Mszps pisany na 1 stronie formatu A4.

31 Pisownia zgodna $\mathrm{z}$ oryginałem; powinno być: intencji. 
obozu narodowego, która o mały włos nie spowodowała usunięcia go z Polski, jego interwiew znany w lewicowym dzienniku, jego ostatnie wmieszanie się tak niefortunne w sprawę Komunikatu biskupów na rzecz rządu par excellence masońskiego, jego ustawiczne mieszanie się w sprawy wewnętrzne diecezji, jak w sprawę Związku Kapłanów w Krakowie ${ }^{32}$, jak Gazety Kościelnej ${ }^{33}$ we Lwowie itp. jego znany list wprost impertynencki do śp. biskupa Pelczara ${ }^{34}$, jego skargi na tego biskupa u rządu, jego ustawiczne oskarżanie biskupów w Rzymie, a skargi tak niesłuszne, że sam Gaspar[r] $\mathrm{i}^{35}$ dać musiał satysfakcję niesłusznie obwinionemu biskupowi Sapieże; wszystko to razem są fakty, które moje stanowisko usprawiedliwiają. On sam by musiał mnie pomówić o nieszczerość, gdyby się dowiedział, że ja po jego oskarżeniach na mnie wynoszę jego zasługi. Ponadto podobne wyszczególnienie nuncjusza musiałoby wprost zaboleć papieża ${ }^{36}$, który po dziś dzień to pamięta, iż opuszczony przez biskupów wyjeżdżał z Pol-

32 Związek Kapłanów (Archi)Diecezji Krakowskiej „Unitas” - wydawca dziennika „Głos Narodu”, w 1926 roku protestował przeciw niektórym zapisom konkordatu, jako niekorzystnym dla Kościoła.

33 „Gazeta Kościelna” - tygodnik poświęcony tematyce religijno-społecznej, organ wydawniczy Towarzystwa Wzajemnej Pomocy Kapłanów Archidiecezji Lwowskiej obrządku łacińskiego pw. Najświętszej Marii Panny Śnieżnej, ukazywał się w latach 1893-1939 we Lwowie. Bibliografia katolickich czasopism religijnych w Polsce 1918-1944, red. Z. Zieliński, Lublin 1981, s. 106-107.

34 Józef Sebastian Pelczar (1842-1924) - święcenia kapłańskie otrzymał w 1864 roku w Przemyślu, doktor teologii i prawa kanonicznego, wikariusz w Samborze i Wojutyczach, wykładowca teologii pastoralnej i prawa kanonicznego w Instytucie Teologicznym w Przemyślu (1870-1877), profesor historii Kościoła i prawa kanonicznego na Wydziale Teologicznym Uniwersytetu Jagiellońskiego, rektor Uniwersytetu Jagiellońskiego (1882-1883), kanonik akademicki kapituły katedralnej na Wawelu (od 1880), biskup pomocniczy diecezji przemyskiej (1899-1900), ordynariusz tejże diecezji (1900-1924), beatyfikowany w 1991 roku, kanonizowany w 2003 roku. C. Niezgoda, Wierny ideałom. Życie, działalność i duchowość Józefa Sebastiana Pelczara (1842-1924), Kraków 1988.

35 Pietro Gasparri (1852-1934) - święcenia kapłańskie otrzymał w 1877 roku w Rzymie, doktor obojga praw, wykładowca prawa kanonicznego w Instytucie Katolickim w Paryżu (1880-1898), w 1898 roku otrzymał sakrę biskupią, delegat Stolicy Apostolskiej w Boliwii, Peru i Ekwadorze (1898-1901), uczestniczył w reformie Kurii Rzymskiej oraz w pracach nad Kodeksem prawa kanonicznego (1917), sekretarz stanu Stolicy Apostolskiej (1914-1930), kardynał (1907). J. Grzywacz, Gasparri Pietro, w: EK, 5, Lublin 1989, kol. 878.

${ }^{36}$ Achilles Ratti (1857-1939) - święcenia kapłańskie otrzymał w 1879 roku, profesor dogmatyki i homiletyki w seminarium duchownym w Mediolanie (1882-1888), pracownik, a następnie prefekt Biblioteki Ambrozjańskiej tamże (1888-1911), prefekt Biblioteki Watykańskiej (1914-1918), w 1918 roku został wizytatorem apostolskim w Polsce i na Litwie, 3 czerwca 1919 roku mianowany arcybiskupem tytularnym Nafpaktos, od 6 czerwca 1919 do 4 czerwca 1921 roku nuncjusz apostolski w Polsce, od 20 kwietnia 1920 roku pełnił także obowiązki komisarza kościelnego na Górnym Śląsku, 13 czerwca 1921 roku mianowany arcybiskupem Mediolanu, a następnie kardynałem; 6 lutego 1922 roku wybrany papieżem jako Pius XI. E. Gigilewicz, S. Wilk, Pius XI, Achille Ratti, w: EK, 15, Lublin 2011, kol. 758-763. 
ski. Sądzę, że byłaby to co najmniej niedelikatność z naszej strony. Wobec braku jedności w Episkopacie na ten plan, bez której trudno by było zaofiarować częścią odmówiony, częścią prawie wymuszony dar. Przyłączam się do wniosku Arcyb[iskupa] Sapiehy, by skoro to inaczej już niemożliwe, Wasza Ekscelencja pierścień ten ofiarował od siebie.

Najoddańsze wyrazy łączę dla Waszej Ekscelencji

+ Teodorowicz

6.

ASIK, $A H$, t. V, cz. 6, s. 301, kard. August Hlond do arcybpa J. Teodorowicza ${ }^{37}$.

Telegram do arcybpa Józefa Teodorowicza z okazji 25-lecia sakry biskupiej

Imieniem obu archidiecezji ${ }^{38}$ i swoim ponawiam najczulsze życzenia $\mathrm{z}$ okazji jubileuszu biskupiego ${ }^{39}$, łącząc się z odruchowym hołdem całej Polski i życząc długich lat dalszej światłej pracy w pełnym zdrowiu i wśród uwielbienia ze strony wdzięcznego Narodu.

August Kard. Hlond

Prymas Polski

7.

ASIK, $A H$, t. V, cz. 28, s. 18-19, arcybp J. Teodorowicz do kard. A. Hlonda ${ }^{40}$.

Wasza Eminencjo!

Wobec tego, że marszałek Trąmpczyński ${ }^{41}$ już pisał do Ameryki w sprawie pieniędzy przed dwoma tygodniami, uznano w bloku na razie za stosowne nie wysyłać nikogo, a tylko ograniczyć się do wysłania listów. Mówiłem tym panom o stanowisku Waszej Eminencji i gotowości napisania listu ogólnie popierające-

${ }^{37}$ Mszps pisany na 1 stronie formatu A4.

$38 \mathrm{Tj}$. gnieźnieńskiej i poznańskiej, które w tym czasie były połączone unią personalną.

39 Arcybiskup Teodorowicz sakrę biskupią otrzymał 2 lutego 1902 roku w katedrze ormiańskiej we Lwowie z rąk kardynała Jana Puzyny. Dnia 16 października 1927 roku we Lwowie celebrowano uroczystości dwudziestopięciolecia sakry i ingresu arcybiskupa Teodorowicza.

${ }^{40}$ Mszps pisany na 2 stronach formatu A4.

${ }^{41}$ Wojciech Trąbczyński (1860-1953) - prawnik, radny miasta Poznania (1901-1911), poseł do sejmu pruskiego (1910-1918), w 1918 roku został naczelnym prezesem Regencji Księstwa Poznańskiego, poseł na Sejm Ustawodawczy (od 14 lutego 1919 pełnił też funkcję marszałka), marszałek senatu I kadencji wybrany z listy Chrześcijańskiego Związku Jedności Narodowej, następnie poseł na sejm II i III kadencji wybrany z listy Narodowej Demokracji. W 1935 roku wycofał się z życia politycznego. J. Łaptos, A. Mania, Trąbczyński Wojciech, w: Kto byt kim w Drugiej Rzeczypospolitej, red. J. Majchrowski, Warszawa 1994, s. 555. 
go ich akcję; otóż wdzięczni bardzo za to, proszą Waszą Eminencję o dwa listy: jeden do biskupa Rhodego ${ }^{42}$ jako prezesa związku polskich księży, a drugi do księdza Wojtalewicza ${ }^{43}$. Ksiądz Wojtalewicz jest to kapłan liczący 65 lat życia, bardzo majętny - liczą go na pół miliona dolarów - a przy tym hojny, zwłaszcza dla spraw w Polsce. On jeden mógłby dać sumę znaczną, a będzie się czuł bardzo zaszczycony listem Waszej Eminencji. Wobec tego, że Wasza Eminencja bardzo ogólnie napisze, proszą panowie bym wysłał list od siebie bardziej konkretny. Prócz tego napisze od siebie marszałek Trąmpczyński jako inicjator i prezes Zjednoczonych stronnictw ${ }^{44}$. Jeśliby się dało jeszcze wyrobić księdzu Wojtalewiczowi jaką szambelanię w Rzymie, oczywiście nie wiem, czy to jest możliwe, to byłoby to już das Höchste der Gesuche ${ }^{45}$.

Listy moje i marszałka Trąmpczyńskiego dołączam z prośbą ${ }^{46}$, by je Wasza Eminencja raczył nadać we Wiedniu, byłoby też bardzo pożądane, by od Siebie listy Wasza Eminencja wysłał równocześnie.

Pieniądze mają być nadesłane na ręce marsz[ałka] Trąmpczyńskiego jako prezesa. Przy tej sposobności donoszę Waszej Eminencji, że do Rzymu przyjedzie X. Biskup Przeździecki ${ }^{47}$. Wpadł on tu do Warszawy, ażeby się wywiedzieć co Piłsudski ${ }^{48}$ mówił z Waszą Eminencją. Miał on wprawdzie już przedtem zamiar

42 Paweł Piotr Rhode (1871-1945) - święcenia kapłańskie otrzymał w 1894 roku, biskup pomocniczy diecezji Chicago (1908-1915), ordynariusz diecezji Green Bay (1915-1945), polski patriota, w 1919 roku odwiedził Polskę, przekazując 30 tys. dolarów jako dar Polonii amerykańskiej na cele dobroczynne, aktywnie wspierał stowarzyszenia polonijne, angażował się w działalność społeczno-charytatywną. R. Nir, Rhode Paweł Piotr, w: Polski słownik biograficzny, 31, Wrocław-Warszawa-Kraków 1988-1989, s. 264-265.

43 Franciszek Wojtalewicz (1861-1942) - święcenia kapłańskie otrzymał w 1889 roku w diecezji chicagowskiej, proboszcz parafii Niepokalanego Poczęcia Najświętszej Marii Panny w Chicago (1895-1942). J. Iwicki, Charyzmat Zmartwychwstańców. Historia Zgromadzenia Zmartwychwstania Pańskiego, 2, 1887-1932, Kraków-Kielce 2007, s. 272, przyp. 28.

${ }^{44}$ Chodzi o Chrześcijański Związek Jedności Narodowej powstały 16 sierpnia 1922 roku z kilku ugrupowań narodowych i chadeckich.

${ }^{45}$ Niem.: najbardziej pożądane.

46 Załącznik do listu nie zachował się.

47 Henryk Przeździecki (1873-1939) - święcenia kapłańskie otrzymał w 1895 roku w Warszawie, od 1903 roku był wykładowcą w Seminarium Duchownym w Warszawie, potem proboszczem parafii pw. św. Józefa w Łodzi (1910-1912), pełnił nieformalną misję informatora Stolicy Apostolskiej o sytuacji Kościoła w Królestwie Polskim (1912-1913); ordynariuszem reaktywowanej diecezji podlaskiej (potem siedleckiej) został w roku 1918, w latach 1919-1924 był sekretarzem Konferencji Episkopatu Polski. K. Kras ow ski, Biskupi katoliccy II Rzeczypospolitej, s. 196-200.

48 Józef Piłsudski (1867-1935) - od lat dziewięćdziesiątych XIX wieku działacz socjalistyczny na Wileńszczyźnie, wydawca „Robotnika” oraz członek Centralnego Komitetu Robotniczego PPS, po roku 1902 aktywny na obszarze Galicji, był współtwórcą Związku Strzeleckiego i Związku Walki Czynnej; podczas pierwszej wojny światowej twórca Polskich Sił Zbrojnych, komendant I Brygady Legionów Polskich, w 1916 roku wszedł w skład tzw. Tym- 
jechać do Rzymu ale się wahał jeszcze. Już bowiem przedtem się dowiedział, że Piłsudski posłał kogoś do Rzymu. Dowiedziawszy się jednak, że była mowa o Konkordacie i komisji papieskiej, zaraz zawołał: „W takim razie jutro każę wyrobić sobie paszport". W ogóle był trochę wystraszony jakąś niepochwytną moim zdaniem zupełnie nieprawdziwą wiadomością, kolportowaną przez jakiegoś księdza, który miał wrócić z Rzymu i mieć z Ojcem św. rozmowę na temat listu biskupów ${ }^{49}$. Wobec tego i wobec zwierzeń się księdza biskupa Przeździeckiego przed Chiarlem ${ }^{50}$ o liście, a nawet autorze listu, poleciłem Księdzu Gawlinie $^{51}$ zaraz list ogłosić. Sądzę jednak, że byłoby dobrze, żeby Wasza Eminencja list wzięła ${ }^{52}$ ze sobą do Rzymu. Wytknąłem to Księdzu Przeździeckiemu, że jednak niepotrzebnie wtajemnicza Chiarla w rzeczy nic go nie obchodzące, ale zdaje mi się, że biskup P[rzeździecki] chciał mieć kryty odwrót w razie, gdyby istotnie Ojciec św. był z listu niezadowolony. Ale podobne paplanie jest fatalne. List wywarł powszechnie bardzo silne wrażenie, a nawet prasa lewicowa nie ma się czego uczepić i prawie, że milczy.

Łączę dla Waszej Eminencji najoddańsze wyrazy czci głębokiej

+ Teodorowicz

Warszawa, d[nia] 7/XII [1]927

czasowej Rady Stanu, od lipca 1917 do listopada 1918 roku więziony przez władze niemieckie, przejął następnie od Rady Regencyjnej Królestwa Polskiego władzę cywilną i wojskową; Naczelnik Państwa (1919-1922) i marszałek Polski (od 1920), po przewrocie majowym (1926) piastował dożywotnio urząd ministra spraw wojskowych i generalnego inspektora sił zbrojnych, premier RP (1926-1928, 1930). J. M. Majchrowski, Pitsudski Józef Klemens, w: Kto byt kim, s. 16.

49 Prawdopodobnie chodzi o List pasterski biskupów polskich w sprawie wyborów, wystosowany 6 grudnia 1927 roku. Zob.: „Miesięcznik Kościelny dla Archidiecezji Gnieźnieńskiej i Poznańskiej” (dalej „MK”), 42, 1927, 11-12, s. 63-65.

${ }^{50}$ Carlo Chiarlo (1881-1964) - sekretarz i audytor Nuncjatury Apostolskiej w Peru (19171922), a następnie Nuncjatury Apostolskiej w Polsce, po wyjeździe z Polski nuncjusza Lorenza Lauriego pełnił obowiązki zastępcy nuncjusza, w 1958 roku mianowany kardynałem. S. Wilk, Nuncjatura Warszawska w II Rzeczypospolitej, w: Nuncjatura Apostolska w Rzeczypospolitej, red. T. Chynczewska-Hennel, K. Wiszowata-Walczak, Białystok 2012, s. 454.

51 Józef Gawlina (1892-1964) - święcenia kapłańskie otrzymał w 1921 roku we Wrocławiu, sekretarz generalny Ligi Katolickiej w Administracji Apostolskiej Górnego Śląska, od 1926 roku kierownik Biura Prasowego Episkopatu, założyciel i pierwszy dyrektor Katolickiej Agencji Prasowej (1927-1929), w 1933 roku mianowany biskupem polowym Wojska Polskiego, członek Rady Narodowej w Londynie (1940-1941), od 1944 roku kierował duszpasterstwem Polaków na emigracji, w 1952 roku został arcybiskupem tytularnym Medytus, brał udział w obradach Soboru Watykańskiego II. K. Krasow ski, Biskupi katoliccy II Rzeczypospolitej, s. 70-73.

52 Pisownia zgodna $z$ oryginałem. 
8.

FKiDOP, t. 140, sygn. 846/262 [7], s. 5-6, kard. A. Hlond do arcybpa J. Teodorowicza ${ }^{53}$.

Ekscelencjo!

Poznań, dnia 24 kwietnia 1928

Pismem z dnia 16 listopada z[eszłego] r[oku] zwróciła się św. Kongregacja Konsystorialna [do] Jego Ekscelencji Ks. Metropolity Sapiehy wskazując na to, że różni księża polscy przybywający do Rzymu na studia mieszkają poza kolegium polskim ${ }^{54}$ i poza papieskim Instytutem na via Pietro Cavallini ${ }^{55}$, usuwając się spod kontroli Wikariatu Rzymskiego i co za tym idzie, swym zachowaniem nieodpowiednim dają niekiedy powód do słusznych skarg. Będąc w Rzymie zbadałem źródło tych żalów i skonstatowałem, że zarówno św. Kongregacja Konsystorialna, jak i Jego Eminencja Ks. Kard. Wikariusz ${ }^{56}$ nie chcą w żaden sposób tolerować dalej zwyczaju, by polscy księża mieszkali w Rzymie u św. Stanisława $^{57}$ lub gdzieindziej bez każdorazowej zgody tegoż Kardynała, który dla zrozumiałych względów chce mieć naszych księży w ewidencji i kontroli, tak jak księży innych narodowości. W tym duchu wystosował Jego Eminencja Ks. Kard. Pompili dnia 3 lutego b.r. do Jego Ekscelencji Ks. Metropolity Sapiehy pismo, w którym raz jeszcze kategorycznie to żądanie stawia, oświadczając, że nie dopuści do ołtarza tych księży, którzy poza Kolegium Polskim i poza Instytutem obiorą sobie mieszkanie bez uprzedniej i wyraźnej zgody Wikariatu.

Wobec tego proszę najuprzejmiej Ich Ekscelencje, aby wysyłając księży do Rzymu, albo ulokowali ich w papieskich Instytutach, albo poprzednio ${ }^{58}$ uzyskali zgodę Wikariatu na inne dla nich mieszkanie.

Sprawa nabrała od jakiegoś czasu bardzo poważnego charakteru i stała się poniekąd kwestią honoru duchowieństwa polskiego w Rzymie. Wiem, że gdyby się w przyszłym roku akademickim ponowiły wypadki wyłamywania się księży

${ }^{53}$ Mszps pisany na podwójnej nieliniowanej kartce formatu A4. W lewym górnym roku: „Prymas Polski”.

${ }^{54}$ Papieskie Kolegium Polskie w Rzymie, erygowane w 1866 roku z inicjatywy ks. Piotra Semenenki CR.

${ }^{55}$ Papieski Instytut Polski w Rzymie, założony w 1909 roku z inicjatywy biskupa Józefa Sebastiana Pelczara.

${ }^{56}$ Basilio Pompilj (1858-1931) - wikariusz generalny Rzymu (1913-1931). Hierarchia Catholica medii et recentioris aevi, sive Summorum pontificum - S. R. E. cardinalum ecclesiarum antistitum series: e documentis tabularii praesertim Vaticani collecta, digesta, edita, 9, a pontificatu Pii PP. X (1903) usque ad pontificatum Benedicti PP. XV (1922), wyd. Z. Pięta, Patavii 2002, s. 11.

${ }^{57}$ Hospicjum Polskie św. Stanisława w Rzymie, założone z inicjatywy kardynała Stanisława Hozjusza w 1575 roku.

58 Wyraz podkreślony. 
polskich spod nadzoru Wikariatu, mogłyby nas spotkać bolesne i upokarzające upomnienie samego Ojca św. I nic w tym dziwnego, bo i my słusznie wymagamy, aby obcy księża w naszych diecezjach stosowali się do przepisów Kurii naszych i nie uchylali się od naszego nadzoru.

Pozwalam sobie dołączyć odpisy listu Jego Eminencji Ks. Kardynała Pompiliego i pisma św. Kongregacji Konsystorialnej.

Raczy Wasza Ekscelencja przyjąć wyrazy najgłębszej czci z jakimi jestem Waszej Ekscelencji powolny i oddany sługa i brat w Chrystusie

+ August Kard. Hlond ${ }^{59}$

Prymas Polski

9.

ASIK, $A H$, t. IV, cz. 3, s. 77, kard. A. Hlond do arcybpa J. Teodorowicza ${ }^{60}$.

Ekscelencjo!

$\mathrm{J}$ [ego] E[kscelencja] Ks. Metropolita Twardowski ${ }^{61}$ wręczył mi pismo W[aszej] E[kscelencji] skierowane do Komisji Prawnej62. Odczytałem je na posiedzeniu. Księża Arcybiskupi byli zdania, że należy skupić wszystko w jednym sekretariacie, który postanowiono powołać do życia jak najrychlej. W tej sprawie rozsyłam do Księży Biskupów załączone pismo z załącznikiem.

Jakże zdrowie Waszej Ekscelencji? Łączę serdeczne pozdrowienie i wyrazy czci najgłębszej.

Waszej Ekscelencji powolny i oddany sługa w Chr[ystusie]

$\mathrm{H} 1[\mathrm{ond}]$ 29/I [19]29

${ }^{59}$ Własnoręczny podpis autora listu.

${ }^{60}$ Mszps pisany na 1 stronie formatu A4.

${ }^{61}$ Bolesław Twardowski (1864-1944) - święcenia kapłańskie otrzymał w 1886 roku we Lwowie, doktor prawa kanonicznego, kanclerz konsystorza metropolitalnego, proboszcz parafii pw. Matki Bożej Nieustającej Pomocy w Tarnopolu (1902-1918), biskup pomocniczy archidiecezji lwowskiej (1918-1923), arcybiskup metropolita lwowski ob. łac. (1923-1944). G. Chajko, Arcybiskup Bolesław Twardowski (1864-1944). Metropolita lwowski obrzadku tacińskiego, Rzeszów 2010.

${ }^{62}$ Komisja Prawna Episkopatu została powołana na zjeździe Episkopatu w Gnieźnie w 1928 roku, w jej skład weszli metropolici, członkowie Komisji Papieskiej oraz sekretarz episkopatu. Do jej zadań należało między innymi przygotowywanie obrad konferencji plenarnych, załatwianie spraw pilnych bądź zleconych przez Konferencję Biskupów. S. Wilk, Episkopat Kościoła katolickiego w Polsce w latach 1918-1939, Warszawa 1992, s. 81-82. 
10.

ASIK, $A H$, t. V, cz. 3, s. 120, arcybp J. Teodorowicz do kard. A. Hlonda ${ }^{63}$.

Wasza Eminencjo!

Dziękuję za otrzymane listy i przepraszam zarazem za opóźnienie moje w odpowiedzi spowodowane brakiem dojrzenia kwestii, które chciałem Waszej Eminencji przedstawić.

Dziękuję też serdecznie za troskę o me zdrowie. Mam się na ogół dobrze i tylko po dwakroć miałem grypę z gorączką i bólem gardła.

Bardzo mi odpowiada myśl zwołania Konferencji do Katowic na maj. Najpierw już obecne zebranie w Warszawie Komisji wskazuje, jak różne kwestie nie cierpią zwłoki i konferencja powinna być co najrychlejsza; a po wtóre Katowice są bardzo miłym, a nawet politycznie rzecz biorąc pożądanym miejscem zbornym. Bądź co bądź będzie to także zamanifestowanie przynależności Śląska do Polski.

Bardzo się ucieszyłem informacją protokółu, że Wasza Eminencja gotów by dać do sekretariatu Księdza Dymka ${ }^{64}$. Daje on i tylko on pełną rękojmię, że sekretariat pójdzie naprawdę; jest jedna jeszcze stąd korzyść, iż on potrafi rozdzielić agendy między Poznań a Warszawę i dwa te ogniska odpowiednio połączyć. A to jest dla Akcji Katolickiej ${ }^{65}$ konieczne. Mnie chodziło w moim wniosku głównie o to, by taki sekretariat w ogóle powstał, a dla siebie tylko o tyle zastrzegłem prowizoryczny udział, o ile chciałem wpłynąć na dobór ludzi. Skoro ksiądz Dymek wchodzi, to i o to nie ma obawy, więc się zupełnie beze mnie obejść może.

A teraz przystępuję do sprawy $\mathrm{Kapa}^{66}$. Uzbierałem wiadomości niestety smutne. Był doskonały kandydat, którego gotów był oddać biskup Łódzki,

${ }^{63}$ Mszps pisany na 1 stronie formatu A4.

${ }^{64}$ Walenty Dymek (1888-1956) - święcenia kapłańskie otrzymał w 1912 roku, wykładowca socjologii w Seminarium Duchownym w Poznaniu, aktywny działacz chrześcijańsko-społeczny, w 1924 roku został sekretarzem generalnym Caritas, biskup pomocniczy archidiecezji poznańskiej (1929-1946), arcybiskup metropolita poznański (1946-1956). P. Nitecki, Biskupi Kościoła w Polsce w latach 965-1999. Stownik biograficzny, Warszawa 2000, s. 86-87.

${ }^{65}$ Akcja Katolicka - organizacja kościelna powołana na początku XX wieku. Jej celem było zaangażowanie osób świeckich w życie Kościoła, działalność ewangelizacyjna, obrona wiary katolickiej i budowanie Królestwa Bożego na ziemi. Formacja członków miała na celu kształtowanie dojrzałych postaw katolików wrażliwych na kwestie społeczne. Statut Akcji Katolickiej w Polsce zatwierdzono w 1930 roku. Wtedy też powstał Naczelny Instytut Akcji Katolickiej z siedzibą w Poznaniu. W struktury Akcji Katolickiej wchodziło szereg organizacji, między innymi Katolickie Stowarzyszenie Kobiet, Katolickie Stowarzyszenie Mężów, Katolickie Stowarzyszenie Młodzieży Męskiej itd. W formacji członków pomagało wydawanie prasy katolickiej oraz literatury. R. Niparko, Akcja Katolicka, w: EK, 1, Lublin 1985, kol. 227-233.

${ }^{66}$ Katolicka Agencja Prasowa. 
z zastrzeżeniem paru dni pobytu $\mathrm{w}$ tygodniu $-\mathrm{X}$. Roszkowski ${ }^{67}$. Skorzystano z mej nieobecności ażeby dzięki nieznajomości terenu ks. Biskupa Lisieckie$\mathrm{go}^{68} \mathrm{i}$ Jałbrzykowskiego ${ }^{69}$ przeforsować kandydaturę zupełnie niemożliwą X. Kaczyńskiego $^{70}$. Jest to człowiek b[ardzo] sprytny, ale umysł bardzo mały; jest pod względem moralnym źle w opinii kwalifikowany; jest nadto prononsowanym partyjnym człowiekiem, który już przez to samo uniemożliwi przeze mnie rozpoczętą konsolidację prasy narodowej i katolickiej. Mnie nie pozostaje wobec tego nic innego jak zrezygnować z[e] złożonej na mnie misji. Dowiaduję się też, że tu w sobotę przyjeżdża biskup Przeździecki, patron tej akcji, ażeby mnie nakłonić do oddania dużego 5 pokojowego mieszkania dla Kapa ${ }^{71}$. Ale mieszkanie raz dla Kapa dawałem, a wtedy uważano, że ono mimo usunięcia się mego z polityki jest zapowietrzone przeze mnie. Użyto nawet nuncjusza za parawan. Niezależnie od tego chciałbym to mieszkanie raczej oddać dla sekretariatu.

Przedstawiam te kwestie Waszej Eminencji i łączę najoddańsze wyrazy czci najgłębszej

$\mathrm{x}$ Teodorowicz

Lwów, d[nia] 5/II [1]929

67 Antoni Roszkowski (1894-1939) - święcenia kapłańskie otrzymał w 1916 roku, pracował w diecezji łódzkiej, profesor ekonomii i nauk politycznych, prawnik, redaktor tygodnika „Słowo Katolickie”, interesował się ruchami społeczno-ekonomicznymi w Europie, duszpasterz robotników. K. M. Pospieszalski, Roszkowski Antoni, w: Polski słownik biograficzny, 32, Wrocław-Warszawa-Kraków 1989-1991, s. 260-261.

${ }^{68}$ Arkadiusz Lisiecki (1880-1930) - święcenia kapłańskie otrzymał w 1904 roku, aktywny działacz społeczny, członek Towarzystwa Czytelni Ludowych, redaktor kwartalnika „Czytelnia Ludowa”, organu Związku Katolickich Towarzystw Robotników Polskich „Robotnik”; zaangażowany w działalność polityczną w Poznaniu, wykładowca seminarium duchownego w Gnieźnie, ordynariusz katowicki (1926-1930). J. Jachowski, Lisiecki Arkadiusz Marian, w: Polski słownik biograficzny, 17, Wrocław-Warszawa-Kraków 1972, s. 453-454.

69 Romuald Jałbrzykowski (1876-1955) - święcenia kapłańskie otrzymał w 1901 roku w Petersburgu, wykładowca w Seminarium Duchownym w Sejnach, działacz społeczny, biskup pomocniczy diecezji augustowskiej (1918-1925), ordynariusz łomżyński (1926), metropolita wileński (1926-1955), sekretarz generalny Konferencji Episkopatu Polski (1925-1926). K. Krasows ki, Biskupi katoliccy II Rzeczypospolitej, s. 99-102.

${ }^{70}$ Zygmunt Kaczyński (1894-1953) - absolwent Akademii Duchownej w Petersburgu (1918), działacz organizacji charytatywnych i oświatowych, poseł na Sejm Ustawodawczy (1919), członek Związku Ludowo-Narodowego, uczestniczył w powstaniu Chrześcijańsko-Narodowego Stronnictwa Pracy (1920), kapelan w wojnie polsko-bolszewickiej (1920), publicysta czasopism: „Pracownik Polski”, „Nowe Życie”, „Rzeczpospolita”, dyrektor Katolickiej Agencji Prasowej (1929-1939), zamordowany przez funkcjonariuszy Urzędu Bezpieczeństwa w 1953 roku. J. Żaryn, Kaczyński Zygmunt, w: Leksykon duchowieństwa represjonowanego w PRL w latach 1945-1989, 1, red. J. My szor, Warszawa 2002, s. 104-106.

${ }_{71}$ Arcybiskup Teodorowicz posiadał w Warszawie przy ulicy Miodowej mieszkanie do własnej dyspozycji. 
11.

ASIK, $A H$, t. V, cz. 4, s. 89, arcybp J. Teodorowicz do kard. A. Hlonda ${ }^{72}$.

Wasza Eminencjo!

Dziękuję Waszej Eminencji za list i łaskawe zaproszenie mnie do Poznania i zaofiarowanie mi gościny, za co serdeczną podziękę składam Waszej Eminencji.

Chciałbym za wszelką cenę być w Poznaniu, by stworzyć jakiś fakt dokonany chociażby w rezolucji dla ustalenia samego zawiązku, a i dla przeszkodzenia partactwu, które już niestety w Warszawie się zaczyna. Tak np. był tu u mnie Przeźdz[iecki], bym dał mieszkanie dla Kaczyńskiego. Oczywiście nie przystałem na to, ale potrzeba co rychlej kwestię np. tę ustalić w związku z całym planem. Dostaję listy księży biskupów z protestem co do Kaczyńskiego. Tymczasem Przeź[dziecki] wychodzi z założenia, że nie można szkodzić Kaczyńskiemu. Sam jednak przyznaje, że X. K[aczyński] ma procesy o obrazę czci. Stąd można wnosić, jaką on się cieszy opinią. Ale to jest jedna tylko kwestia. Gorzej jest, że Ks. P[rzeździecki] już się zajął sam poza mną ustalaniem kandydatów księży do biura centralnego prasowego. Na moje zastrzeżenia, że przecie ludzi już angażowałem cofnął się, ale i tu jest wzgląd, by sprawę szybko przygotować. Dlatego koniecznie mi potrzeba widzieć się z Waszą Eminencją. Niestety, teraz jest komunikacja niemożliwą i nie wiedzieć czy się ustali do soboty. Gdyby się ustaliła, zawiadomię Waszą Eminencję telefonicznie.

Tymczasem łączę dla Waszej Eminencji najoddańsze wyrazy czci głębokiej i szacunku

+ Teodorowicz

Lwów, 12/II [1]929

12.

ASIK, $A H$, t. V, cz. 28, s. 41-42, arcybp J. Teodorowicz do kard. A. Hlonda ${ }^{73}$.

Wasza Eminencjo!

Lwów, d[nia] 17/V [1]929

Podczas pobytu mojego w Warszawie, dowiedziałem się szczegółów, z którymi chcę się podzielić z Waszą Eminencją. Opowiadał mi prałat Godlewski ${ }^{74}$, od

${ }^{72}$ Mszps pisany na 1 stronie formatu A4.

${ }_{73}$ Mszps pisany na 2 stronach formatu A4.

${ }^{74}$ Marceli Godlewski (1865-1945) - święcenia kapłańskie otrzymał w 1888 roku, jeden z prekursorów katolicyzmu społecznego, działał na rzecz poprawy bytu robotników, zakładając między innymi Stowarzyszenie Robotników Chrześcijańskich (1905), członek Ligi Narodowej, Komitetu Narodowego Polskiego (1914-1917), proboszcz parafii pw. Wszystkich Świętych w Warszawie (1915-1945), publicysta i wydawca prasy katolickiej, związany z ruchem narodowym. K. Madaj, M. Żuławnik, Proboszcz getta, Warszawa 2010. 
którego nabywa O. Pawelski ${ }^{75}$ księgarnię, że mu Pawelski wspominał o planach co do księdza Dymka ale dodał, że z tej kandydatury nic nie będzie. Natknąłem się też na ustny komplet ludzi pracujących pod wodzą O. Pawelskiego, rzekomo wysuwających prymat Kard. Kak[owskiego], a w istocie pragnących zawładnąć wszystkim. Przychodzi mi na myśl, którą poddaję rozwadze Księdza Prymasa, czy by nie należało w tej sprawie rozmówić się Waszej Eminencji z O. Ledóchowskim $?^{76}$ Ledóchowski zna wybornie Pawelskiego i w czasie wojny na przedstawienie przez Sapiehę jego intryg w episkopacie usunął go z prowadzenia redakcji Przeglądu Powszechnego ${ }^{77}$, a dał go w odstawkę do domu rekolekcyjnego we Lwowie. Dziś on intrygą swoją niby to tylko na tle 2 kardynałów, w gruncie rzeczy uniemożliwia całą akcję episkopatu. Względy więc są aż nadto poważne, by nie oglądając się na Kard. Kak[owskiego], przeniósł go.

Co do domu to jeszcze raz atakował mnie biskup Przeździecki, który w tej sprawie miał pisać do Waszej Eminencji, ale oparłem się mówiąc, że całą sprawę zdałem w ręce Waszej Eminencji.

Z mej strony przy wynajmie zastrzegam sobie termin zapisu dwuletni, który jak przypuszczam będzie więcej formalnością, potrzebne mi to jednak zastrzeżenie w związku z planami moimi co do mej diecezji, które jednak są jeszcze w dalszym polu. Co do terminu wynajmu i płacy, to pozostawiam to osądzeniu Waszej Eminencji, prosiłbym tylko, by data płacy czynszu odpowiadała terminowi wynajmu i z nim się schodziła, a to ze względu na przedstawione mi przez księdza zarządzającego domem trudności finansowe spowodowane dwuletnim już oczekiwaniem próżnego mieszkania na sekretariat. Za próżne mieszkanie musi jednak mimo to opłacać podatki i inne prostacje, tak że się ustawicznie do tego lokalu dokłada i to w chwili gdy wielka restauracja dachu jest konieczną. Kaczyński robi co może, ażeby się zadomowić i utrwalić. Oczywiście, chodzi około mnie i mowę moją przeznaczoną dla Polski wydrukował w Kapie.

75 Jan Pawelski (1868-1944) - święcenia kapłańskie otrzymał w 1894 roku w Krakowie w zakonie jezuitów, współpracownik „Przeglądu Powszechnego”, a następnie jego redaktor naczelny (1902-1918), duszpasterz i organizator katolickich stowarzyszeń w Warszawie (1919-1926), opiekun Towarzystwa im. Piotra Skargi w Warszawie (1927-1944), pisarz społeczno-kulturalny. Encyklopedia wiedzy o jezuitach na ziemiach Polski i Litwy 1564-1995, oprac. L. Grzebień, Kraków 1995, s. 494.

${ }^{76}$ Włodzimierz Ledóchowski (1866-1942) - święcenia kapłańskie otrzymał w 1894 roku w Krakowie w zakonie jezuitów, ich prowincjał galicyjski (1902-1906), asystent Asystencji Niemieckiej w Rzymie (1906-1915), wreszcie - generał (1915-1942); przyczynił się do odnowy duchowej zakonu oraz powstania wielu nowych placówek, także misyjnych, w czasie drugiej wojny światowej zabiegał o sprawy polskie w Stolicy Apostolskiej. Encyklopedia wiedzy o jezuitach, s. 357-358.

77 „Przegląd Powszechny” - jezuicki miesięcznik społeczno-kulturalny i religijny założony przez o. Mariana Morawskiego w Krakowie w 1884 roku, zawierał artykuły z zakresu literatury, historii, filozofii, teologii, religioznawstwa, kultury itp. Ukazywał się z przerwami do 2012 roku. Encyklopedia wiedzy o jezuitach, s. 547. 
Przy tej sposobności pozwolę sobie przesłać Waszej Eminencji bardzo spóźnione życzenia przeoczonych przeze mnie Imienin Waszej Eminencji, które w tym przede wszystkim się schodzą obecnie, by się Wasza Eminencja nie dał zabrać do Rzymu mimo, iż wielu dostojników Kościoła u nas się wyraziło, że to byłaby najlepsza kandydatura dla Rzymu ${ }^{78}$.

Całując pierścień zasyłam najoddańsze wyrazy czci najgłębszej

+ Teodorowicz

Polecam pamięci Waszej Eminencji sprawę Ks. Węglewicza ${ }^{79}$.

13.

ASIK, $A H$, t. V, cz. 3, s. 121, arcybp J. Teodorowicz do kard. A. Hlonda ${ }^{80}$.

\section{Wasza Eminencjo!}

Odbyłem w Warszawie konferencję z B. B ${ }^{81}$. w sprawie postulatów naszych. Niestety przekonałem się, że oni nic nie mogą zrobić, a tylko im zależy, by uzyskać pozoru, iż Kościół do nich się udaje. Chcieli koniecznie, bym im dał coś na piśmie. Ale właśnie dlatego nie dałem im nic.

Co do ks. Badeniego ${ }^{82}$, to on nie pójdzie na tę konferencję, swego udziału w akcji katolickiej ${ }^{83}$. Szkoda, bo trzeba by koniecznie kogoś. Jakoś do księdza Adamskiego ${ }^{84}$ jak to z różnych stron słyszę księża zaufania nie mają.

${ }_{78}$ Aluzja do rzekomej planowanej nominacji kardynała A. Hlonda na prefekta Kongregacji Rozkrzewiania Wiary w Rzymie. Takie informacje krążyły wówczas wśród duchowieństwa, kulisy sprawy nie są jednak znane. Wiadomo, że kardynał Hlond nigdy takiej funkcji nie objął.

${ }^{79}$ Mieczysław Węglewicz (1889-1943) - święcenia kapłańskie otrzymał w 1915 roku, pedagog, wychowawca młodzieży, metodyk nauczania religii, redaktor naukowy „Miesięcznika Katechetycznego i Wychowawczego", profesor Seminarium Duchownego w Warszawie (1919-1927), kanonik tamtejszej kapituły metropolitalnej, członek komisji ministerialnej z zakresu podręczników do nauczania religii, autor publikacji naukowych z dziedziny dydaktyki, psychologii i pedagogiki katolickiej. J. Kostkiewicz, Kierunki i koncepcje pedagogiki katolickiej w Polsce 1918-1939, Kraków 2013, s. 611-612, przyp. 287.

${ }^{80}$ Mszps pisany na 1 stronie formatu A4.

${ }^{81}$ Prawdopodobnie chodzi o Bezpartyjny Blok Współpracy z Rządem, znany powszechnie pod nazwą BBWR - organizację polityczną działającą w latach 1927-1935, skupiającą środowiska związane z sanacją.

${ }^{82}$ Henryk Badeni (1884-1943) - święcenia kapłańskie otrzymał w 1908 roku we Lwowie, doktor teologii, kanonik gremialny kapituły metropolitalnej we Lwowie (1914-1943), oficjał sądu biskupiego tamże, protonotariusz apostolski. J. Wołczański, Listy biskupa Józefa Sebastiana Pelczara, s. 351, przyp. 487.

83 Pisownia zgodna z oryginałem.

${ }^{44}$ Stanisław Adamski (1875-1967) - święcenia kapłańskie otrzymał w 1899 roku w Gnieźnie, działał w różnych organizacjach społeczno-oświatowych, poseł na Sejm Ustawodawczy (1919-1922), senator (1922-1927), dyrektor Księgarni św. Wojciecha w Poznaniu, koordynator 
Dowiaduję się z różnych stron, między innymi od p[ana] Dąbrowskiego ${ }^{85}$, że wielki jest ferment z powodu ustąpienia O. Jacka ${ }^{86}$. Z nim samym ani mówiłem, ani korespondowałem. Wiem o tym jednak, że on sam głęboko jest przekonany o niechęci do niego polskiego episkopatu i uważa swoje powołanie do Rzymu za ścisłe następstwo tej niechęci. Twierdzi on, że sam podał plan reorganizacji studium w Lublinie, a dziś to się przeprowadza jakoby przeciw niemu. Mówił o tym do kogoś bardzo zaufanego, który mnie o tym powiedział.

Bardzo mi odpowiada ten plan, który mi przedstawił $\mathrm{p}$ [an] Dąbrowski dotyczący bractwa: bo utwierdza on z jednej strony władzę i rolę prymasa w Polsce, a z drugiej wytwarza obóz katolickiego apostolstwa.

Bardzo dobrze zrobił Wasza Eminencja, że pojechał do Paryża na obchód pogrzebowy ${ }^{87}$.

Kończę oświadczeniem, że jestem na usługi Waszej Eminencji w kwestii bractwa, gdyż wspominał mi pan Dąbrowski po rozmowie z Waszą Eminencją, że mógłbym się może w czym przydać.

Całuję pierścień Waszej Eminencji i łączę najoddańsze wyrazy czci najgłębszej

+ Teodorowicz

Lwów, d[nia] 4/X [1]929

działań Akcji Katolickiej, ordynariusz katowicki (1930-1967). K. Krasowski, Biskupi katoliccy II Rzeczypospolitej, s. 16-22.

${ }^{85}$ Stefan Dąbrowski (1877-1947) - od 1913 roku profesor Wydziału Lekarskiego Uniwersytetu Lwowskiego, uczestnik obrony Lwowa w 1918 roku, delegat rządu Ignacego Paderewskiego przy misji koalicyjnej gen. Barthélemy’ego ds. Małopolski Wschodniej, poseł na sejm z ramienia Związku Ludowo-Narodowego (1922-1935), wiceprezes Stronnictwa Narodowego (1928-1935), rektor Uniwersytetu Poznańskiego (1945-1947). G. Mazur, Dąbrowski Stefan Tytus, w: Kto byt kim, s. 92.

86 Jacek Woroniecki (1878-1949) - święcenia kapłańskie otrzymał w 1906 roku w Lublinie, w 1909 roku obronił doktorat z socjologii na Uniwersytecie we Fryburgu Szwajcarskim i wstąpił do dominikanów. Wykładowca teologii moralnej i etyki na KUL (1919-1929), rektor KUL (1922-1924), wykładowca na Uniwersytecie Angelicum w Rzymie (1929-1933). Po powrocie do kraju rektor dominikańskiego Studium Filozoficzno-Teologicznego we Lwowie, w Warszawie i w Krakowie. Pozostawił bogaty dorobek naukowy. Z. Mazur, Woroniecki Jacek Adam, w: Słownik polskich teologów katolickich 1918-1981 (dalej: SPTK), 7, red. L. Grzebień, Warszawa 1983, s. 431-443.

87 Prawdopodobnie chodzi o pogrzeb Louisa-Ernesta Duboisa (1856-1929), arcybiskupa metropolity Paryża (1920-1929), kawalera Orderu Orła Białego (1926). 
14.

ASIK, $A H$, t. IV, cz. 3, s. 78, kard. A. Hlond do arcybpa J. Teodorowicza ${ }^{88}$.

Ekscelencjo!

Dziękuję za pismo z dnia 4 bm. Centrala A[kcji] K[atolickiej] rusza w tych dniach z miejsca. Dobrze, że w ogóle mamy sposób na zorganizowanie i uruchomienie tej ważnej placówki. Życie i czas naprowadzą na właściwe metody i na właściwych ludzi.

Mam wrażenie, że idea BSP $^{89}$ krystalizuje się należycie. Prawdopodobnie jeszcze w bieżącym roku zaczniemy pracować na chwałę Bożą.

Alia alias ${ }^{90}$. Tymczasem serdecznie W[aszą] E[kscelencję] pozdrawiam i z czcią najgłębszą jestem W[aszej] E[kscelencji] oddany w Chr[ystusie] sługa i brat.

$\mathrm{Hl}[$ ond]

\section{5.}

ASIK, $A H$, t. V, cz. 3, s. 122, arcybp J. Teodorowicz do kard. A. Hlonda ${ }^{91}$.

Wasza Eminencjo!

Proszę darować opóźnienie w mej odpowiedzi, lecz list Waszej Eminencji krążył, zanim mnie tu w Marienbadzie ${ }^{92}$ dopadł. Prawdę powiedziawszy nie bardzo wiem o co idzie, bo nie mam przed oczami szkicu statutu, ale zdaję się w tej sprawie na Waszą Eminencję. Zasadniczo jak Wasza Eminencja i my wszyscy jestem za tym, ażeby statut był jak najbardziej ogólnikowy, jak najmniej zawierał niepotrzebnych szczegółów, które dopiero eksperyment sam uzupełniać i poprawiać będzie.

Całując pierścień Waszej Eminencji łączę najoddańsze wyrazy czci najgłębszej

+ Teodorowicz

Marienbad, 27/VII [1]930

Notre Dame

${ }^{88}$ Mszps pisany na 1 stronie formatu A4.

${ }^{89}$ Nie udało się rozszyfrować skrótu.

90 Łac.: o innym kiedy indziej.

91 Mszps pisany na 1 stronie formatu A4.

${ }_{92}$ Mariańskie Łaźnie (niem. Marienbad) - miejscowość wypoczynkowa w zachodnich Czechach. 
ASIK, $A H$, t. V, cz. 18, s. 150-151, arcybp J. Teodorowicz do kard. A. Hlonda ${ }^{93}$.

\section{Wasza Eminencjo!}

Pani Korfantowa ${ }^{94}$ przybyła do Warszawy, i instancjonowała [się] u Kardynała Kakowskiego, prosząc go o interwencję u prezydenta. Kardynał użył argumentów, jakimi niestety aż nazbyt szafowano u nas podczas dyskusji o tym, że to na nic się nie zda, że biskupi już kroki poczynili etc. Wrażenie oczywiście było najfatalniejsze. Bo nie tego żądała pani Korfantowa i nie na to liczy społeczeństwo, by coś osiągnąć, ale wszystkim na tym zależy by episkopat był rzecznikiem pogwałconego prawa i ludzkości ${ }^{95}$. Odmowa, a raczej jakby odmowa Kardynała była przyjęta jako odmowa Episkopatu i społeczeństwo zawiedzione na episkopacie, który wypada ze swej roli tylekroć ujawnionej, zwracają się do kół profesorów uniwersytetu etc., etc., którzy w miejsce nas, ze swej strony przygotowują protest publiczny. Klęska moralna dla nas jaka się powinie za tym grzechem opuszczenia, nie da się wprost obliczyć. Dałoby się to jedynie jeszcze naprawić, gdyby Wasza Eminencja zwrócił się chociażby pisemnie do prezydenta. Może to nawet i lepiej. Ostatnie słowo Waszej Eminencji było, że się jeszcze nad sprawą tą namyśli. Episkopat cały był w zasadzie za interwencją, a tylko nie umiał odnaleźć stosownej formy, bo jak zwykle najważniejsze sprawy załatwiamy z największym pośpiechem. Brakło więc czasu i na to. Jakkolwiek Wasza Eminencja postanowi i zdecyduje, uważałem za swój obowiązek poinformować Waszą Eminencję o stanie rzeczy o tyle zmienionym na niekorzyść nieinterwencji biskupów, gdyż podczas konferencji jeszcze była mowa o naszej inicjatywie. Dziś zaś inicjatywa wyszła ze strony proszących i już częściowa jakby odmowa jest. Mówię, jakby odmowa, bo Kardynał ściśle mówiąc nie odmówił wprost i pozostawił dlatego otwartą drogę interwencji Waszej Eminencji. Jeśliby może ułatwić, to mogło wystąpienie Waszej Eminencji, gdyby mógł w liście do prezydenta o coś zaczepić, to dołączam na wszelki wypadek prośbę żony jednego z uwięzionych $\mathrm{p}$ [ana] Dębskiego ${ }^{96}$. Proszono mnie o to, bym to uczynił.

93 Mszps pisany na 2 stronach formatu A4.

94 Elżbieta Korfantowa z domu Sprot (1882-1966) - śląska działaczka społeczna i polityczna związana z chadecją, posłanka na Sejm Śląski (1930-1935), żona Wojciecha Korfantego.

95 Aluzja do aresztowań byłych opozycyjnych posłów sejmowych przez władze sanacyjne w nocy z 9 na 10 września 1930 roku i osadzenia ich w twierdzy w Brześciu nad Bugiem.

${ }^{96}$ Aleksander Dębski (1890-1942) - prawnik, wojewoda wołyński (1925-1926), poseł na sejm z listy Stronnictwa Narodowego (1928-1930), po skończonej kadencji aresztowany we wrześniu 1930 roku i przetrzymywany w Brześciu nad Bugiem, nie był sądzony w tzw. procesie brzeskim, w 1935 roku wszedł w skład Komitetu Głównego Stronnictwa Narodowego, aresztowany i zamordowany przez Niemców w czasie drugiej wojny światowej. A. Dudek, Dębski Aleksander, w: Kto byt kim, s. 166. 
Modlę się gorąco o światło Ducha św. tu w tej sprawie tak doniosłej i całując pierścień Waszej Eminencji zasyłam najoddańsze wyrazy, przepraszając za bardzo dorywcze i niechlujne pismo

+ Teodorowicz

Po napisaniu listu przybył $\mathrm{p}$ [an] Stefan Dąbrowski z petycją wszystkich żon, nie wyłączając socjalistek, więc on już sam Eminencji tę listę doręczy.

Warszawa, d[nia] 8/X/[1]930

17.

ASIK, $A H$, t. V, cz. 18, s. 187-190, arcybp J. Teodorowicz do kard. A. Hlonda ${ }^{97}$.

Wasza Eminencjo!

Ponieważ X. A[dam] Sapieha dziś wyjeżdża, a w Krakowie czekają go liczne narady i zajęcia, przeto polecił mi, bym zdał sprawę Waszej Eminencji z bytności naszej u X. Kard. Kakowskiego. Byliśmy obaj u X. Kard[ynała] dzisiaj rano i X. A[dam] Sapieha zapytał X. Kardynała, czy i kiedy odbędzie się nasza konferencja? Na to otrzymał odpowiedź, że zebranie nasze nie odbędzie się wcale, albowiem Wasza Eminencja i słyszeć nie chce o żadnym projekcie złączonym ze sprawą Brześcia. Wówczas X. A[dam] Sapieha oświadczył X. Kardynałowi, iż wobec tego czujemy się zwolnieni z zobowiązania do solidarności i każdy z biskupów ma prawo działać na własną rękę. Komunikując to Waszej Eminencji nie mogę tego utaić, że mnie w pierwszej chwili oświadczenie A[dama] Sapiehy zaskoczyło, ale przekonawszy się, że ma ono głębsze podłoże i jest wyrazem wewnętrznego kryzysu, jaki w episkopacie przeżywamy, pragnę Waszej Eminencji przedłożyć wytworzoną sytuację z całą czcią dla Jego Osoby, z pełnym uznaniem dla Jego niezwykłych darów i zdolności, i z całym zaufaniem, że Wasza Eminencja zrozumie pobudki mojego kroku. Osobno jeszcze od siebie dodam, że moja decyzja, ażeby Waszej Eminencji całą wyspowiadać prawdę, tak była nagła i niespodziana, że jeszcze wczoraj wieczór ani o podobnym liście jaki piszę myślałem, a dopiero dziś rano przede mszą św. tak mi od razu i wyraźnie stanęły wczoraj jeszcze dla mnie samego zamglone prawdy i tak głęboko uczułem obowiązek nieukrywania przed Waszą Eminencją niczego, że uważać to musiałem za wewnętrzne natchnienie od Boga, tak że czułbym się w sumieniu niespokojnym, gdybym nie napisał Waszej Eminencji wszystkiego.

Na poprzednim posiedzeniu dał nam X. Kard. Kakowski niedwuznacznie do poznania, choć tego wprost nie wymówił, że Wasza Eminencja z umysłu na naradę nie przybył. Nie wierzę temu. Ale, Wasza Eminencjo pozwól, że Ci powiem, iż stanęliśmy przed pytaniem: Dlaczego Wasza Eminencja zachorowawszy nie

${ }_{97}$ Mszps pisany na 4 stronach formatu A4. 
odwołał zebrania i dlaczego mając przybyć za kilka dni do Warszawy nie przybył wówczas, gdyśmy pod koniec stycznia wszyscy tu byli. Stało się to zapewne bez winy Waszej Eminencji, ale stało się fatalnie bo się zrodziły pozory, że Wasza Eminencja ucieka przed nami. A przecież wielka chwila przynaglała do wymiany zdań. Tyle rzeczy chcieliśmy Waszej Eminencji powiedzieć. Chcieliśmy powiedzieć na podstawie długoletniego doświadczenia, że jak na ambonie, tak w odezwaniach się biskupów nastrój chwili odgrywa tak ważną rolę, że najpiękniejsze słowo po czasie mija bez wrażenia, [podczas] gdy nawet słabe słowo w chwili ogólnego naprężenia wywołuje wrażenie olbrzymie (das bessere ist des guten Feind ${ }^{98}$ ). Chcieliśmy Waszej Eminencji powiedzieć, że wedle naszego poczucia taka chwila, jak ta, i taka sposobność, jak ta, powołania się na uczyniony już krok Kościoła, dania nauczki głowie państwa za zignorowanie głosu prymasa, a przede wszystkim upomnienie się o odmowę księdza więźniom, więcej nie wraca.

Chcieliśmy poinformować Waszą Eminencję, że sami konserwatyści z B.B. ${ }^{99}$ prosili o słowo biskupie, które by im dało oparcie przeciw wewnętrznemu terrorowi. Zdzisław Lubomirski ${ }^{100}$ wprawdzie do proszących nie należał, ale mówił biskupowi krakowskiemu, że chcą rządowi zagrozić złożeniem mandatów.

Chcielibyśmy w końcu powiedzieć, że wedle nas nie należało dopiero czekać na akt zamroczenia sumienia pasterskiego, ale należało ten akt ostrzeżeniem naszym uprzedzić ${ }^{101} \mathrm{i}$ tak spełnić nie jakiś rozumowany akt polityczny, ale obowiązek sumienia społecznego. Tego wszystkiego wynurzyć Waszej Eminencji nie mogliśmy, tak jak nie mogliśmy wysłuchać planów Waszej Eminencji i racji w takiej chwili. A przecież dla tego celu ja przedsięwziąłem podróż w mych latach tak ciężką, raz do Warszawy, a potem z Wiednia znowu do Warszawy. Podróż, trud, koszty duże, to jeszcze najmniejsze, ale moralne nasze przeżycia, te są złem właściwym. Jak gdyby szatan tu chciał nas rozstroić. Pozory i znowu pozory są tak fatalne, że można dziś mówić o kryzysie Konferencji Episkopatu, na co wskazują słowa biskupa Sapiehy i wprowadzenie w grę przez Kardynała osoby nuncjusza. Nie mówił on tego wyraźnie, ale tośmy zrozumieli. A szkoda! Szkoda nieobliczalna! Jeśli społeczeństwo od chłopa do biskupa, do profesora do urzędnika woła o głos episkopatu to dlatego, że występy episkopatu zdobyły sobie

98 Niem.: Lepsze jest wrogiem dobrego.

99 BBWR.

${ }^{100}$ Książę Zdzisław Lubomirski (1865-1943) - potomek arystokratycznej rodziny polskiej, absolwent studiów prawniczych na uniwersytetach w Krakowie i Grazu, w czasie pierwszej wojny światowej przystąpił do Komitetu Narodowego Polskiego, uczestniczył w życiu społeczno-politycznym Warszawy, był między innymi członkiem Rady Regencyjnej Królestwa Polskiego i prezydentem Warszawy, w Polsce niepodległej senator z listy BBWR (19281938), po wybuchu drugiej wojny światowej aresztowany i więziony przez Gestapo, zmarł w wyniku doznanych w więzieniu obrażeń. J. Pajewski, Lubomirski Zdzisław, w: Polski słownik biograficzny, 18, Wrocław-Warszawa-Kraków 1973, s. 66-69.

101 „Ostrzeżeniem naszym uprzedzić” - wyrazy podkreślone. 
autorytet, jakiego nie ma nigdzie bodaj na świecie. Był on solą w oku wielu. Kryzys takiej Konferencji i takiego autorytetu jest kryzysem, a raczej może się stać kryzysem Kościoła w Polsce. Proszę i darować słowa zbyt może śmiałe i bezwzględne, ale podyktowane miłością sprawy i pragnieniem gorącym, by Wasza Eminencja miał w episkopacie wpływ taki, jaki jest dzisiaj dla dobra wspólnej sprawy niezbędny. Dlatego niejasności takich jak obecne i w takich chwilach jak obecne między nami być nie powinno. Lepiej, że szczerze o tym powiem Waszej Eminencji licząc na to, że krok mój Wasza Eminencja jak należy oceni.

W postscriptum jeszcze słowo pro domo sua ${ }^{102}$. Z dawna mówiono mi pośród biskupów, że Wasza Eminencja widocznie uważa mój kierunek za szkodliwy, że stara się mnie usunąc choćby nawet $\mathrm{z}$ ambony, gdy się tylko do tego nastręczą sposobności. Ależ i owszem. To zupełnie rozumiem. Jeśli Eminencja jest tego przekonania, to to zupełnie oceniam, a do prac i występów nie tylko się nie rwę, ale przeciwnie, pragnę w spokoju dokończyć prac życia i przygotować się na śmierć. Ale Wasza Eminencja w ostatnim liście do Kardynała ostrzega przed oddawaniem odezw politykowi ${ }^{103}$, którego ciasny horyzont polityczny nie dozwala mu się wznieść do szerszego horyzontu. Wszyscy biskupi i kardynał wzięli te słowa za przejrzystą aluzję do mnie. Nie myślę polemizować z przekonaniem Waszej Eminencji o mnie. Ale doprawdy zapytać muszę, jaki to cel może mieć takie deptanie mnie? Osobiście dziękuję Bogu za to bene mihi Domine quia humiliasti me! ${ }^{104}$ Ale zdaje mi się jednak, że jeżeli ja na takie określenie zasługuję, to $\mathrm{w}$ takiej chwili wewnętrznego napięcia przychodzi ono co najmniej nie w porę.

Łączę dla Waszej Eminencji najoddańsze wyrazy czci i szacunku

+ Teodorowicz

W razie, jeśliby oświadczenie Księdza Kardynała o odmownym stanowisku zasadniczym wobec Brześcia polegało na nieporozumieniu i jeśliby informację z poprzedniej Konferencji o przygotowaniu przez Waszą Eminencję jakiegoś ogólnego listu, w którym i Brześć byłby przejrzyście wytknięty, były prawdziwe, w takim razie proszę liczyć na nasze poparcie. Mówię o przypuszczeniu, bo nie mam prawa bez porozumienia ręczyć za innych. Lepiej późno jak nigdy; myśmy zresztą i tamtym razem oświadczyli, że za takim pismem jesteśmy, a chcieliśmy tylko by Brześć był bezpośrednio wytknięty, czego wedle nas domagała się sama konsekwencja pierwszego kroku Waszej Eminencji oprócz znanych powodów. Tylko prywatnie i poufnie od siebie dodaję, że Sapieha tylko w takim razie gotów jest nawrócić i do Warszawy przybyć, jeśli go Wasza Eminencja bliżej i konkretnie o planach Swych powiadomi. To mówię zupełnie od siebie, gdyż on nie wie

\footnotetext{
102 Łac.: we własnej sprawie, dla swojej korzyści.

103 Wyraz podkreślony.

104 Łac.: Dobrze, mój Panie, żeś mnie upokorzył.
} 
nawet o tym, że ten list jak pisałem, w ostatniej chwili zaimprowizowany piszę Waszej Eminencji. Oczywiście, nie tylko jest w takim razie wskazany, ale i konieczny pośpiech, bo ukazanie się osobnych odezw nie jest wykluczone.

Po napisaniu listu widziałem się z biskupami Przeździeckim i Łukomskim ${ }^{105}$. Podają projekt zwołania Konferencji ogólnej lub też komitetu biskupiego. Byliśmy we 3 u kardynała w tej sprawie, który ma się odnieść do Waszej Eminencji. Zdaje mi się, że lepsza jest rzecz zwołać Komitet. Ale Wasza Eminencja wybrnie. Warszawa, d[nia] 29/I [19]31

\section{8.}

ASIK, $A H$, t. V, cz. 18, s. 198-200, kard. A. Hlond do arcybpa J. Teodorowicza ${ }^{106}$.

\section{Ekscelencjo!}

Jestem W[aszej] E[kscelencji] naprawdę wdzięczny za cenne pismo z dnia 29 stycznia i zaraz najmocniej przepraszam, jeżeli w czymkolwiek W[aszej] E[kscelencji] uchybiłem. Nie będę się tłumaczył jakby tego moja miłość własna chciała, lecz pokornie proszę o przebaczenie i o łaskawe uspokojenie mnie, że się $\mathrm{W}$ [asza] E[kscelencja] z mojej winy nie martwi. Poza tym dla mnie najboleśniejszym momentem osobistego stosunku W[aszej] E[kscelencji] do mnie, otworzył mi list W[aszej] E[kscelencji] oczy na to, że pewien zbieg okoliczności wywołuje wrażenie umyślnego z mej strony unikania obrad nad sprawą brzeską. Otóż dla sprecyzowania istotnego stanu rzeczy w kwestii mojego, powiedziałbym oficjalnego, stosunku do Episkopatu pragnę zaznaczyć:

a) W sprawie brzeskiej pisał do mnie przed Bożym Narodzeniem J[ego] E[minencja] Ks. K[ardynał] K[akowski], donosząc mi, że Księża B[isku]pi P[rzeździecki] i Ł[ukomski] proponują zwołanie Kom[isji] Praw[nej]. Na zapytanie $\mathrm{J}$ [ego] Em[inencji] co o tym sądzę odpowiedziałem, że po prawdzie nie jestem za publicznym wystąpieniem Ep[iskopatu], ale się od omówienia sprawy na Kom[isji] Praw[nej] nie uchylam, na co otrzymałem zawiadomienie, że Ko[misja] Praw[na] tymczasem nie będzie zwołana.

b) Krótko przed końcem ubiegłego roku pisał mi J[ego] Em[inencja] Ks. Me$\operatorname{tr}$ [opolita] Sap[ieha] stawiając w poroz[umieniu] z W[aszą] E[kscelencją]

105 Stanisław Łukomski (1874-1948) - święcenia kapłańskie otrzymał w 1898 roku, zaangażowany w działalność oświatową i społeczną, proboszcz katedry poznańskiej i kanonik kapituły metropolitalnej tamże (1916-1920), biskup pomocniczy archidiecezji poznańskiej (1920-1926), ordynariusz łomżyński (1926-1948), sekretarz generalny Konferencji Episkopatu Polski (1926-1946). K. Krasowski, Biskupi katoliccy II Rzeczypospolitej, s. 159-163.

${ }^{106}$ Mszps pisany na 3 stronach formatu A4. Jest to ostateczna wersja listu kardynała A. Hlonda do arcybiskupa J. Teodorowicza. W Acta Hlondiana znajdują się także dwie pierwsze wersje listu (s. 191-197), nie zostały jednak uwzględnione w niniejszej edycji. 
i Ks. Metrop[olitą] Tward[owskim] wniosek, by się jednak nad sprawą brzeską zastanowiła Kom[isja] Prawna. Właśnie byłem się schronił na tydzień do klasztoru lądzkiego ${ }^{107}$, gdzie mi nie posyłano poczty, bo miałem inne b[ardzo] pilne prace. Po powrocie do Poznania napisałem do J[ego] Em[inencji] Ks. K[ardynała] K[akowskiego], proponując mu ewentualne zwołanie Kom[isji] Praw[nej] na 15 stycznia a to dlatego, że na 14 stycznia już byłem sobie zamówił rozmowy z Min[istrami] Hubickim ${ }^{108}$ i Kozłowskim ${ }^{109}$. Posiedzenie zostało zwołane. Tymczasem z nocy 12 na 13 stycznia zachorowałem nie na chorobę polityczną ${ }^{110}$, lecz na silną febrę gastryczną ${ }^{111}$, w której przeleżałem 13 i niemal cały 14 stycznia. Wyglądało mocno to na grypę, osłabiło mnie niemało i wyjazd do Warszawy stał się fizycznie niemożliwy ${ }^{112}$. Posiedzenia odwołać nie mogłem, bo ja go nie zwołuję i na nim nie przewodniczę. Może się ono i beze mnie odbyć, tak się już odbywało takie bez Ks. Kard. Kak[owskiego]. Byłoby wyglądało na mocno niewłaściwą pretensję z mej strony gdybym był [za]żądał, by z powodu mojej nieobecności sesja się nie odbyła. Nie mogłem oczywiście wiedzieć, że zbierze się tak mała liczba członków, która moim zdaniem była jednak uprawniona do odbycia sesji, bo nie ma postanowienia, że wymagana jest obecność połowy członków. Była to pierwsza sesja na którą nie przybyłem. Inni absentowali się częściej.

c) O zwołaniu Kom[isji] Praw[nej] na koniec stycznia nic nie słyszałem. Wprawdzie zapytywał mnie Ks. Bp P[rzeździecki] krótko przed opuszczeniem Krynicy, czy mógłbym być z końcem stycznia w W[arszawie] i wspomniał o tym, że wtedy W[asza] E[kscelencja] z Wiednia wraca, ale czynił to w takiej formie, że [z]rozumiałem, iż W[asza] E[kscelencja] programowo przyjeżdża do W[arszawy] na dłuższy czy krótszy pobyt, a nie umyślnie na sesję, o której nie było żadnej wzmianki. Najspokojniej odtelegrafowałem Ks. B[iskupowi] $\mathrm{P}[$ rzeździeckiemu], że z końcem grudnia nie zamierzam ruszać się z Poznania

${ }^{107}$ Chodzi o klasztor Towarzystwa Chrystusowego w Lądzie nad Wartą.

108 Stefan Hubicki (1877-1955) - lekarz, w czasie pierwszej wojny światowej współorganizator Polskiej Organizacji Wojskowej w Rosji, szef służby sanitarnej Obszaru Warownego Grodno i innych, komendant Wojskowej Szkoły Sanitarnej, od 1928 roku generał brygady, minister pracy i opieki społecznej (1930-1934), członek Rady Funduszu Pracy i komisarz Zakładu Ubezpieczeń Społecznych (1934-1939), w czasie drugiej wojny światowej organizował pomoc dla uchodźców na Węgrzech, po 1945 roku praktykował jako lekarz. J. Gołębiowski, Hubicki Stefan Bolesław, w: Kto byt kim, s. 42.

109 Leon Kozłowski (1892-1944) - archeolog, profesor Uniwersytetu Lwowskiego, poseł na sejm z listy BBWR (1928-1935), senator (1935-1939), pełnił między innymi funkcję ministra reform rolnych, podsekretarza stanu w Ministerstwie Skarbu, ministra spraw wewnętrznych; podczas drugiej wojny światowej internowany w Berlinie, gdzie zmarł. J. Gołębiow ski, Kozłowski Leon Tadeusz, w: Kto byt kim, s. 48.

${ }^{110}$ Wyraz podkreślony.

111 „Febrę gastryczną” - wyrazy podkreślone.

112 „Fizycznie niemożliwy” - jw. 
i mocno się zdziwiłem, gdy z listu W[aszej] E[kscelencji] dowiaduję [się], że znowu ja jestem winien, że sesja nie przyszła do skutku.

d) Pod koniec swego listu porusza W[asza] E[kscelencja] myśl zwołania sesji na 3 lutego, o czym pisze mi także Ks. Kard. Kakowski. Sądzę, że w dzis[iejszej] sytuacji należy dać wszystkim możność wypowiedzenia się, a to tym więcej, że sprawa istotnie wszystkich prosto obchodzi. Wprawdzie ten dzień dla mnie i dla dalej od W[arszawy] mieszkających B[isku]pów niewygodny z tego powodu, że 2 lutego Biskupi mają funkcje w Katedrach ${ }^{113}$ i trudno będzie niejednemu zdążyć na sesję, ale już nie chciałem proponowanej daty [zmieniać] i telegraficznie zwołałem Konf[erencję] Ep[iskopatu].

Tyle pozwalam sobie zakomunikować W[aszej] E[kscelencji] dla wyttumaczenia się z zarzutu jakobym uciekał przed Episkopatem. Tłumaczę się, nie oskarżam nikogo, do nikogo nie mam żalów. Pragnę tylko, aby nas nieszczęsny Brześć nie poróżnił.

Zresztą proszę pokornie, aby W[asza] E[kscelencja] był przekonany o mej najgłębszej czci i uwielbieniu, z jakimi się zawsze do Eks[elencji] odnosiłem i odnoszę.

W[aszej] E[kscelencji] powolny sługa w Chr[ystusie] $\mathrm{Hl}[\mathrm{ond}]$ 1.2.[19]31

19.

ASIK, $A H$, t. V, cz. 28, s. 64, arcybp J. Teodorowicz do kard. A. Hlonda ${ }^{114}$.

Wasza Eminencjo,

Przesyłam odpisy w sprawie auta, łącząc dla Waszej Eminencji najoddańsze wyrazy czci najgłębszej

+ Teodorowicz

Lwów, 14/IV [1]931

[Załącznik nr 1]

Odpis

Ministerstwo

Wyznań Religijnych i Oświecenia Publicznego

Warszawa dn[ia] 26 września $1928 \mathrm{r}$.

Zaświadczenie

Pobieranie podatku od samochodów księży Biskupów, jako od przedmiotów zbytku

113 Z powodu święta Matki Bożej Gromnicznej.

114 Mszps pisany na 1 stronie formatu A4. 
Na skutek prośby J[ego] E[kscelencji] Ks. Arcybiskupa J[ózefa] Teodorowicza Ministerstwo stwierdza, że wszelkie środki lokomocji, jak powozy i samochody należące do Księży Biskupów posiadają charakter służbowo-reprezentacyjny. Podlegają one przeto tymże przepisom, jakie obowiązują dla wszelkich odnośnych obiektów służbowych i reprezentacyjnych, dlatego też winny być zwolnione od podatku za przedmioty zbytku.

p.o. Dyrektora Departamentu Bogdański m.p. Naczelnik Wydziału

[Załącznik nr 2]

Ministerstwo

Wyznań Religijnych i Oświecenia Publicznego

Warszawa dn[ia] 26 września $1928 \mathrm{r}$.

Do

Jego Ekscelencji Ks. Arcybiskupa

Józefa Teodorowicza

we Lwowie

Pobieranie podatku od samochodów księży Biskupów, jako od przedmiotów zbytku.

Czyniąc zadość prośbie Waszej Ekscelencji, Ministerstwo przesyła zaświadczenie co do zwolnienia samochodów oraz innych środków lokomocji, z których korzystają Ordynariusze od podatku nakładanego na przedmioty zbytku.

p.o. Dyrektora Departamentu

Bogdański m.p.

Naczelnik Wydziału

20.

ASIK, $A H$, t. IV, cz. 21, s. 36, kard. A. Hlond do arcybpa J. Teodorowicza ${ }^{115}$.

29 IV 1931

Ekscelencjo!

Dziękuję uprzejmie za łaskawe przesłanie mi odpisu dokumentu ministerialnego w sprawie samochodów należących do księży biskupów. Wprawdzie jest w nim mowa o zwolnieniu od podatku za przedmioty zbytku i nie wynika z niego, że nasze samochody mają być również zwolnione od podatku drogowego, który opłacać trzeba m[iędzy] i[nnymi] od autobusów, niezakwalifikowanych

115 Mszps pisany na 1 stronie formatu A4. 
jako przedmioty zbytku. Spodziewam się atoli, że władze rządowe nie będą nas pociągały do podatku drogowego, przyznając naszym samochodom charakter urzędowy na równi z samochodami posiadanymi przez władze państwowe i samorządowe. Takie stanowisko byłoby ze wszechniar słuszne i sprawiedliwe.

Telegrafowałem dzisiaj Waszej Ekscelencji, że nie odbędzie się dnia 24 b.m. sesja Komisji Prawnej. Przyznam się, że w swym liście do J[ego] Em[inencji] Ks. Kardynała Kakowskiego, który jako przewodniczący Komisji ją zwołuje, zaznaczyłem, że wprawdzie sesję proponuję, ale wolałbym, by sesja odbyła się później, bo mógłbym lepiej wykończyć wiadomą pracę. Ks. Kardynał postanowił odłożyć sesję do późniejszego terminu także z tego powodu, że na 24 nie mogliby się stawić ani Książę Metropolita Sapieha, ani Arcybiskup Jałbrzykowski, a z powodu słabości prawdopodobnie nie przyjechałby Metropolita Twardowski. Ponieważ zatem przewiduję nie bez podstawy, że Metropolita Szeptycki nie będzie chciał zabierać głosu w znanej sprawie, zakończyłoby się na tym, że na sesji spotkałaby się mniejsza połowa Arcybiskupów, przez co sesja minęłaby się ze swoim celem.

Przesyłam Waszej Eksc[elencji] serdeczne życzenia jak najskuteczniejszej kuracji i z wyrazami najgłębszej czci i oddania jestem W[aszej] Eks[celencji] powolny sługa w Chrystusie

$\mathrm{H} 1[\mathrm{ond}]$

21.

ASIK, $A H$, t. V, cz. 28, s. 7, arcybp J. Teodorowicz do kard. A. Hlonda ${ }^{116}$.

Wasza Eminencjo!

Wysyłał mnie biskup Krakowski do Warszawy w sprawie „Polonii”"117, ale potem cofnął się, pisząc mi, że Wasza Eminencja sam pragnie się zając sprawą „Gł[osu] N[arodu]"118. Ucieszyłem się z tego, bo byłoby to niepowetowaną klęską dla sprawy, gdyby się nam rzecz ta z rąk wymknąć miała. Następnie nawet finansowo jest to czysty i pewny interes. Tylko należy się bardzo spieszyć, bo jak

$116 \mathrm{JW}$.

117 „Polonia” - dziennik ogólnoinformacyjny założony przez Wojciecha Korfantego, ukazywał się w latach 1924-1939. Głoszono w nim hasła autonomii Górnego Śląska oraz zamieszczano artykuły dotyczące tego regionu: polityki, gospodarki, szkolnictwa, kultury itp. oraz informacje o charakterze ogólnopolskim. A. Lis, „Polonia” wobec najważniejszych wydarzeń politycznych $w$ Polsce $w$ okresie międzywojennym: zamachu stanu $w 1926$ roku i procesu brzeskiego, „Rocznik Historii Prasy Polskiej”, 19, 2016, 3, s. 75-90.

118 „Głos Narodu” - dziennik polityczny, społeczny i literacki założony przez Józefa Rogosza. Ukazywał się w Krakowie w latach 1893-1939. M. Jakubek, Prasa krakowska 17951918. Bibliografia, Kraków 2004, s. 76. 
mi mówił X. Korzonkiewicz ${ }^{119}$ pertraktacje z tamtej strony prawie są na ukończeniu. X. Mazanek ${ }^{120}$ sekretarz X. Sapiehy ma najdokładniejsze wiadomości o stronie finansowej. Dlatego byłoby wprost niezbędnym bliższe porozumienie się z X. M[azankiem].

Załatwiając się z tą sprawą korzystam ze sposobności, ażeby zwrócić uwagę Waszej Eminencji na brak w programie dzisiejszej Konferencji zapowiedzianej dyskusji nad moim projektem. Jeżeli się odniosłem znanym pismem do każdego z księży biskupów, to miałem w tym wiadomy cel. Po stylu projektu bowiem poznałem od razu autora X. P[rzeździeckiego]. Wiedziałem też, że autor był tylko narzędziem nieświadomym działającym wprawdzie w dobrej woli, ale posuwanym na radziwiłłowskiej szachownicy przez jezuitów. Dowodów na to nie miałem oczywistych, ale poszlaki i to grube były.

Otóż zależało mi na tym, ażeby przez pewien rozgłos powstrzymać dalsze podobne próby na przyszłość prowadzące nas do następstw nieobliczalnych. Dlaczego więc teraz ta sprawa w tak aktualnej chwili zdjętą zostaje wbrew zapowiedzi z porządku dziennego? A druga sprawa to sprawa uchwały Konferencji powierzającej Waszej Eminencji napisanie znanego listu. Wasza Eminencja przypomina Sobie zapewne, iż mi zlecił na me odnośne zapytanie głosić wszędzie, że list taki się ukaże. Wasza Eminencja też różnym panom mówił to od siebie. Dziś jest chyba niepodobieństwem po tak uroczystych zapewnieniach wycofać się.

Daruje Wasza Eminencja, że piszę tak otwarcie, ale powoduje mną wzgląd na sprawę, a powiem też, że i w niemałej mierze wzgląd na Osobę Waszej Eminencji. Liczę na to, że mi Wasza Eminencja mej otwartości nie weźmie za złe i łączę najoddańsze wyrazy czci głębokiej.

+ Teodorowicz

Lwów, d[nia] 29/9 [1]931

119 Jan Korzonkiewicz (1877-1932) - święcenia kapłańskie otrzymał w 1902 roku w Krakowie, penitencjarz w kościele Mariackim w Krakowie (1906-1914), prof. Starego Testamentu na Wydziale Teologicznym Uniwersytetu Jagiellońskiego, rektor krakowskiego seminarium duchownego (1915-1920), kanonik krakowskiej kapituły katedralnej (1919-1932). J. Urban, Katedra na Wawelu po 1918 roku, Kraków 2008, s. 480, przyp. 518.

${ }^{120}$ Stefan Mazanek (1895-1950) - święcenia kapłańskie otrzymał w 1918 roku w Krakowie, kapelan i sekretarz arcybiskupa Adama Sapiehy (1920-1932), kanclerz kurii metropolitalnej w Krakowie (1932-1950), kanonik krakowskiej kapituły katedralnej (od 1937), protonotariusz apostolski. B. Przybyszewski, Mazanek Stefan, w: Polski słownik biograficzny, 20, Wrocław-Warszawa-Kraków 1975, s. 288-289. 
ASIK, $A H$, t. IV, cz. 21, s. 43, arcybp J. Teodorowicz do kard. A. Hlonda ${ }^{121}$.

30.9.[19]31

Ekscelencjo!

Bardzo się ucieszyłem pismem W[aszej] E[kscelencji] i zaraz śpieszę z odpowiedzią.

1) W sprawie dziennika zdecydowany jestem zaproponować Episkopatowi rozwiązanie krakowskie. Jeżeli Księża Biskupi w zasadzie zgodzą się na projekt, najchętniej przyłożę ręki do tego, moim zdaniem, b[ardzo] ważnego dzieła. Ale pragnę, by Episkopat uważał sprawę za swoją i by mi pewne kościelne okręgi nie mogły zarzucać, że stwarzam pismo dla siebie i dla swoich celów. Pozycja „Polski” ${ }^{22}$ jest, zdaje się, stracona mimo niemałych ofiar. Nie winię nikogo, ale szkoda wielka i mimo wszystko pewna klęska dla sprawy.

2) Pismo wspólne w znanej sprawie przygotowałem i przedłożę na Konferencji. Nie ma o tym wzmianki w programie, bośmy ten temat $\mathrm{z}$ umysłu pomijali w programach i protokołach.

3) Wniosek W[aszej] E[kscelencji] będzie w czasie Konferencji omówiony i rozpatrzony przez Komisję Prawną w komplecie i w obecności W[aszej] E[kscelencji]. Tak uchwaliła Kom[isja] Prawna na swoim posiedzeniu dnia 29 lipca. $\mathrm{Z}$ tej też racji nie ma tej sprawy w programie Konferencji, której atoli Kom[isja] Prawna może ją przekazać, o ile to uzna za potrzebne.

Raczy W[asza] E[kscelencja] przyjąć wyrazy mojej czci najgłębszej i oddania. Powolny sługa w Chr[ystusie]

$\mathrm{H} 1[\mathrm{ond}]$

23.

ASIK, $A H$, t. V, cz. 10, s. 230, arcybp J. Teodorowicz do kard. A. Hlonda ${ }^{123}$.

Wasza Eminencjo!

Śpieszę powiadomić Waszą Eminencję, że wyszła świeżo książka w druku sejmowym pt. „Ankieta Konstytucyjna Sejmu R[zeczypospolitej] P[olskiej]” 124 .

${ }^{121}$ Mszps pisany na 1 stronie formatu A4.

122 Prawdopodobnie chodzi o gazetę „Polonia”.

${ }^{123}$ Mszps pisany na 1 stronie formatu A4. FKiDOP, t. 130, sygn. 1210/420 (12) [7], brudnopis listu pisany ręką arcybpa Teodorowicza, b.d., s. 132.

124 [Warszawa 1931]. 
W tej książce po wstępnym referacie Cara ${ }^{125}$ są podane uwagi Episkopatu Polski w przedmiocie zmiany konstytucji. Wydrukowane są na str[onach] 15-18. Wobec tego raczy Wasza Eminencja publicznie już ogłosić pismo z odpowiednim zastrzeżeniem, które by się dostało do publicznej wiadomości.

Łączę dla Waszej Eminencji wyrazy najgłębszej i najoddańszej czci + J[ózef] Teodorowicz Lwów, dnia 23 października 1931

24.

ASIK, $A H$, t. V, cz. 28, s. 92, arcybp J. Teodorowicz do kard. A. Hlonda ${ }^{126}$.

Wasza Eminencjo!

Biskup Krakowski rad by pomówić z Waszą Eminencją w sprawie „Głosu Narodu" i prosi, czy by Wasza Eminencja nie pofatygował się do mnie o godzinie 10, gdzie byśmy Waszą Eminencję oczekiwali. Proszę do siebie, gdyż mam telefon zamówiony w rannych godzinach i wydalać się nie mogę.

Najoddańsz[e] i najgłębsze wyrazy czci łączę

+ Teodorowicz

Warszawa, 18/XII [1]931

25.

ASIK, $A H$, t. V, cz. 27, s. 298-300, arcybp J. Teodorowicz do kard. A. Hlonda ${ }^{127}$.

Wasza Eminencjo!

Krynica $^{128}$, d[nia] 28/I [1]932

Dowiedziawszy się, że odjeżdża dziś Ks. Prądzyński ${ }^{129}$ skorzystałem, ze sposobności, by napisać Waszej Eminencji to, o czym w pocztą przesyłanych listach dziś pisać jest trudno.

125 Stanisław Car (1882-1938) - adwokat i sędzia, pracownik Tymczasowej Rady Stanu, polityk związany z BBWR, minister sprawiedliwości (1928-1930), poseł na sejm (19301938), marszałek sejmu (1935-1938), bliski współpracownik Józefa Piłsudskiego. J. Gołębiowski, Car Stanistaw, w: Kto byt kim, s. 33-34.

126 Mszps pisany na 1 stronie formatu A4.

127 Mszps pisany na 3 stronach formatu A4.

128 Krynica - miejscowość wypoczynkowa w Małopolsce Zachodniej.

129 Józef Prądzyński (1877-1942) - święcenia kapłańskie otrzymał w 1901 roku, organizator życia społeczno-gospodarczego w Wielkopolsce, wydawca prasy i literatury religijnej, członek Ligi Narodowej, senator I kadencji z ramienia Stronnictwa Narodowego, sekretarz generalny Związku Kapłanów „Unitas” (1917-1925), od 1925 roku jego prezes, duszpasterz akademicki w Poznaniu, zginął w Dachau. G. Mazur, Prądzyński Józef, w: Kto byt kim, s. 540. 
Wspomniał mi Ksiądz Biskup Radoński ${ }^{130}$, że Wasza Eminencja wobec trudności z Warszawą ma zamiar w razie cofnięcia dokonanej decyzji przez episkopat wydać list pasterski ${ }^{131}$ sam. Ponieważ wszystko na to wskazuje mi, że sytuacja zupełnie odpowiada temu, co wiem o załamaniu się Warszawy, więc witam jako wybawienie nasze zamiar i ewentualny krok Waszej Eminencji. Załamanie się Warszawy od dawna nie jest dla mnie niespodzianką, a nawet nie mogło być dla mnie niespodzianką. Tyle przecie razy patrzyłem na to, jak nasze warszawskie bizancjum ${ }^{132}$ przyparte chwilowo do muru przez głos episkopatu odskakiwało zaraz później jak sprężyna naciśnięta do swojego dawnego miejsca. Chwilowy odruch kapłańskiego sumienia był zawsze i stale przy każdej zwłoce zdławiony w tej duszy bizantynizmem. Tym bardziej należało się lękać tego teraz. Już w przeszłym roku odezwa choćby krótka stokroć gorsza i słabsza jaka by była wydana zaraz po Brześciu, miałaby za sobą to jedno, że nie ostawiłaby czasu na zwłokę, a tym samym na cofnięcie się. Ale szkoda czasu o tym pisać, co Waszej Eminencji tak dobrze jest znane.

Otóż o tej sytuacji decyzja Waszej Eminencji mam nadzieję wstrząśnie episkopatem. Biskup Przeździecki jak zawsze powolny sługa urabia opinię biskupów w ten sposób, że wykazuje im, jak daleko skuteczniejszym będzie list wydany później! Będzie rząd trzymać w szachu i to będzie rzekomo dla Kościoła lepsze.

Tym argumentem wziął Łukomskiego, a przypuszczam, iż zachwiał i innych. Otóż tego rodzaju uśmiercenie listu odsunięciem go ad calendas graecas ${ }^{133}$, stanie się niemożliwym z chwilą gdy Wasza Eminencja oświadczy, że list ten sam wyda. Wtedy staną biskupi przed aut aut ${ }^{134}$. Myślę, że wstyd będzie tym, którzy pokrywali ucieczkę mądrością stanu cofać się już bez żadnej rezerwy argumentów, a przy tym nie zechcą wziąć na swe sumienie rozbicie konfederacji. Będzie to tym trudniejsze, o ile główny aranger $\mathrm{z}$ ramienia K[akowskiego] sam wołał w roku zeszłym o konieczność wystąpienia i sam kładzie taki nacisk na Konferencję. Musi im też zrozumieć, że nieukazanie się listu jest zdezawuowaniem roboty, planu i stanowiska Waszej Eminencji, które idzie aż do tych granic, iż

${ }^{130}$ Karol Radoński (1883-1951) - święcenia kapłańskie otrzymał w 1909 roku w Gnieźnie, redaktor naczelny „Przewodnika Katolickiego”, biskup pomocniczy poznański (19271929), ordynariusz włocławski (1929-1951). W czasie drugiej wojny światowej przebywał w Londynie, gdzie organizował duszpasterstwo dla emigrantów. P. Nitecki, Biskupi Kościoła w Polsce, s. 372.

${ }^{131}$ Chodzi o projektowany wówczas list pasterski na temat procesu, w którym sądzeni byli przywódcy opozycji centrolewicowej, przeprowadzonego w dniach 26 października 1931-13 stycznia 1932 roku przed Sądem Okręgowym w Warszawie (tzw. proces brzeski); skazano w nim na więzienie dziesięciu i uniewinniono jednego z oskarżonych.

132 Chodzi o kardynała Aleksandra Kakowskiego; arcybiskup Teodorowicz ma tu na myśli uległość tego hierarchy wobec władz państwowych.

133 Łac.: odłożyć na czas nieokreślony.

134 Łac.: albo, albo. 
krok Waszej Eminencji jest już ostatecznym, a koniecznym następstwem wytworzonej sytuacji przez P[rzeździeckiego] i tych, których on zachwiał. Sądzę więc, że krok Waszej Eminencji, a raczej uświadomienie sobie, że taki zamiar Wasza Eminencja ma i że spełni, uratuje sprawę $e^{135}$.

Jeśliby jednak miało się stać inaczej, to należy sobie powiedzieć, że luboć136 położenie będzie gorsze, ale również i w tym położeniu krok Waszej Eminencji będzie ocaleniem. Albowiem on uświadomi bizantynizmowi, że wyzyskiwanie solidarności episkopatu dla służalczego milczenia już dalej nie przyjdzie. Ten krok też uświadomi tym, którzy bizantyjskimi narzędziami się posługują, że i to się na nic nie zda. $\mathrm{Z}$ dwojga złego episkopat zwarty w milczeniu i złudzeniu sumienia, a episkopat choćby nie zupełny, a stojący za prymasem, to ostatnie nie tylko jest nieskończenie lepszym, ale wprost jest to ratunkiem. Bo przecież to jest jasne, że jeśli list Waszej Eminencji nie będzie ogłoszony, to obrońcami idei moralnej w Polsce i jej rzecznikami będą ci, co ją deptali zawsze, ale w procesie ją podnieśli i aureolą męczeńską opromienili - Witosy ${ }^{137}$, Liebermany ${ }^{138}$, Mastki ${ }^{139}$. Jasnym też być musi, że za swe milczenie Kościół zapłaciłby straszliwie z chwilą śmierci dziś bardzo już chorego człowieka, w czasach zamieszek jakie nastąpią. Swym śmiałym wielkodusznym krokiem przewidującym przyszłość, a rozumiejącym straszną odpowiedzialność ciążącą na Kościele obecnie Wasza Eminencja ratuje nas wszystkich. W adresach hołdowniczych znajdą się wówczas prawie wszyscy, tak że jedność episkopatu w innej tylko formie zaznaczoną i wyrażoną zostanie. O ile by zaś przez brak hołdowniczych sukcesów ze strony kilku okazał

135 „Uratuje sprawę” - wyrazy podkreślone.

136 Przestarzała forma: choć, chociaż.

137 Wincenty Witos (1874-1945) - poseł na Sejm Krajowy galicyjski i do austriackiej Rady Państwa, członek Ligi Narodowej (1917-1918), prezes Polskiego Stronnictwa Ludowego „Piast” (1918-1931), dwukrotny premier (28 maja-14 grudnia 1923, 10-15 maja 1926), zdecydowany przeciwnik rządów sanacyjnych, w 1930 roku uwięziony w twierdzy brzeskiej, a w tzw. procesie brzeskim skazany na półtora roku więzienia, w latach 1933-1939 przebywał na emigracji w Czechosłowacji, w roku 1935 i 1938 wybrany zaocznie na prezesa Stronnictwa Ludowego, w czasie drugiej wojny światowej więziony przez Niemców i bezskutecznie namawiany do współpracy, w 1945 roku wybrany na prezesa PSL. J. Gołębiowski, Witos Wincenty, w: Kto byt kim, s. 74.

138 Herman Liebermann (1870-1941) - prawnik, jeden z przywódców Polskiej Partii Socjaldemokratycznej Galicji i Śląska Cieszyńskiego (PPSD), poseł do austriackiej Rady Państwa (1907-1918) oraz na Sejm Ustawodawczy (z listy PPSD), Sejm I i II kadencji (z listy Polskiej Partii Socjalistycznej) i III kadencji (z listy Centrolewu), więziony i skazany w procesie brzeskim na dwa i pół roku więzienia, od 1933 roku przebywał na emigracji we Francji. M. Śliw a, Lieberman Herman, w: Kto byt kim, s. 345-346.

139 Mieczysław Mastek (1893-1942) - działacz PPSD, aktywny w Związku Zawodowym Kolejarzy, w 1929 roku został posłem na sejm II kadencji z listy Polskiej Partii Socjalistycznej, organizator kongresu Centrolewu w Krakowie (1930), w tzw. procesie brzeskim skazany na trzy lata więzienia (1932), członek Komitetu Zagranicznego PPS w Londynie. M. Śliwa, Mastek Mieczysław, w: Kto byt kim, s. 362. 
się brak pełnego zespołu to z pewnością należy ubolewać nad tym, ale i tak wszyscy o tym braku zespołu wiedzą i dla nikogo to nie jest więcej tajemnicą, forma zaś hołdowniczych ustaw pisanych przez jednych przy braku innych w niczym razić nie może i nie podkreśla braku jedności.

Wobec rządu będzie to wystąpienie, które mu da wiele do myślenia. Dziś on liczy na nasze rozdwojenie i pozwala sobie na publiczne lekceważenie nas i na próby zastraszenia. Ujrzy, że się nie lękamy niczego, gotowi przyjąć otwartą walkę religijną, na którą jednak oni dziś nie przejdą.

Przy tym w tym wypadku najgorszym, do którego jak myślę nie dojdzie, tj. usunięcia się cząstki biskupów mimo wystąpienia z listem Waszej Eminencji, do innych wyliczonych przez mnie przyczyn dołączyłaby się jeszcze jedna na pozór osobista, a w istocie zasadnicza. Jasnym to jest, że prędzej czy później ideologia Waszej Eminencji a ideologia bizantyjska zetrzeć się ze sobą muszą. List Waszej Eminencji już był zespolił cały episkopat przy tej ideologii, a więc i przy prymasie, który po raz pierwszy stał się wodzem zespalając umysły wszystkich w najdonioślejszej sprawie. Próba podważenia listu jest próbą może nieuświadomioną podważenia w ogóle stanowiska moralnego Waszej Eminencji, które niezawodnie wobec rozpowszechniania informacji o liście musiałoby być przez niewydanie listu podważone. Wobec bizantynizmu Wasza Eminencja przegrywa, a biskupów stojących za Waszą Eminencją nie byłoby widać. Czyli było by zlekceważenie prymasa i jego przegrana. Z chwilą, kiedy Wasza Eminencja Sam list wydaje szanse się od razu zmieniają i pobitym zostaje w walnej rozprawie wschód.

Pozwoliłem sobie zaprzątnąć czas Waszej Eminencji myślami, które mi się nasunęły. Przepraszam za niedbałą formę, ale w ostatniej dopiero chwili na list się zdecydowałem.

Łączę dla Waszej Eminencji najoddańsze wyrazy czci głębokiej

+ Teodorowicz

O ile mi się wydaje, Wasza Eminencja miał pełnomocnictwo i podpisy wszystkich biskupów do wydania listu po procesie tak, że ta sprawa w ogóle już została przesądzoną. 
26.

ASIK, $A H$, t. V, cz. 27, s. 301, kard. A. Hlond do arcybpa J. Teodorowicza ${ }^{140}$.

Ekscelencjo!

P[oznań], d[nia] 5/2 [19]32

Otrzymałem listy i zupełnie sobie uświadamiam obecną sytuację. Toteż wbrew pierwotnemu postanowieniu swojemu wyjeżdżam w niedzielę do Rzymu. Resztę będzie już Ekscelencja rozumiał.

Życzę pomyślnej kuracji i z wyrazami najgł[ębszej] czci jestem W[aszej] E[kscelencji] powolny i oddany sługa w Chr[ystusie]

$\mathrm{Hl}[\mathrm{ond}]$

27.

ASIK, $A H$, t. V, cz. 28, s. 88, arcybp J. Teodorowicz do kard. A. Hlonda ${ }^{141}$.

Krynica, probostwo 27/2 [1]932

Wasza Eminencjo!

Rzucam w pośpiechu myśl pod wpływem wiadomości o niebywałym wystąpieniu Czuja ${ }^{142}$. Czy by nie było dobrze, by w formie odpowiedzi na zapytanie $\mathrm{Kapa}^{143}$ lub innej, Wasza Eminencja piętnując postępek Czuja, tym samym dał odpowiedź pośrednią rządowi na jego zlekceważenie naszego kroku? Czy by nie można teraz przy tej sposobności silniej wyrazić co nasza zbyt oględna odezwa nie dopowiedziała? Czy nie można by powiedzieć już też o tym, że wszelkie komentarze nieuzasadnione w brzmieniu ustawy są bezwartościowe, już też o tym, że ustawy godzące w stan posiadania Kościoła w szkolnictwie muszą prowadzić do walki religijnej? Czy nie byłoby też i wskazane podnieść zasługi obrońców ustawy?

Rzucam tych kilka uwag łącząc najoddańsze wyrazy czci najgłębszej + Teodorowicz

140 Mszps pisany na 1 stronie formatu A4.

$141 \mathrm{JW}$.

142 Jan Czuj (1886-1957) - święcenia kapłańskie otrzymał w 1912 roku w Tarnowie, doktor teologii w zakresie patrystyki (1916), katecheta gimnazjalny w Brzesku (1917-1938), poseł na sejm (1922-1935), profesor Wydziału Teologii Katolickiej Uniwersytetu Warszawskiego (od 1938), a następnie pierwszy rektor Akademii Teologii Katolickiej w Warszawie (1954-1956), zaangażowany w działalność społeczno-polityczną i pisarską, w czasach stalinizmu należał do ruchu księży patriotów. A. Nowak, Słownik biograficzny kapłanów diecezji tarnowskiej 1786-1985, 2, Tarnów 2000, s. 141-142.

143 Katolicka Agencja Prasowa. 
Piszę bardzo dorywczo i poddaję te myśli rozwadze Waszej Eminencji, bo czuję, że nasze milczenie rodzi pozory za B. B. ${ }^{144} \mathrm{u}$ katolików, że nam wyjaśnienie rządu wystarczyło. Nie wiem czy już nie za późno, ale gdyby nawet tak było, to bodaj moralną wartość będzie miało to czy inne oświadczenie. Oczywiście ani sytuacji, ani jej przebiegu nie znam bliżej, więc niechaj Wasza Eminencja rozważy i rozstrzygnie.

28.

ASIK, $A H$, t. V, cz. 28, s. 90-91, arcybp J. Teodorowicz do kard. A. Hlonda ${ }^{145}$.

\section{Wasza Eminencjo!}

Piszę na papierze, jaki mam pod ręką błagając Eminencję, by natychmiast pojechał do Warszawy w sprawie szkolnej i próbował w porozumieniu z posłami ułożyć klauzulę poddaną senatowi. Klauzula ta miałaby na celu w ustawodawstwie zastrzec $\mathrm{w}$ duchu konkordatu prawa szkolnictwa katolickiego. Jest to ostatnia godzina i nie wiem, czy już nie za późno. Należało to uczynić zaraz ${ }^{146}$ po liście Prystora ${ }^{147}$ w odpowiedzi na ten list. Pisałem też zaraz do Sapiehy, czy wszedł z Waszą Eminencją pod tym względem w porozumienie, nie odpisał mi jednak nic. Dziś gdyby rząd widział silny nacisk biskupów, którego niestety z naszej winy nie widział i gdyby się lękał rozdwojenia we własnym Klubie, to kto wie, czy nie ustąpi. Nasze milczenie wobec jego obłudnej interpretacji było wzięte dla uśpienia i tak niewrażliwego sumienia katolików z B. B. ${ }^{148}$ Trudno! Radziliśmy dorywczo. 5 minut przeznaczyliśmy na najważniejsze oświadczenie, przewidywaliśmy tylko jedną ewentualność, która właśnie nie nastąpiła, a nie przewidywaliśmy innych, a potem gdy trzeba było przemówić zamilkliśmy więc się stało to, co się stało. Nasza wina! Silne wystąpienie choć spóźnione może jeszcze rzecz uratuje, a jeśli nawet nie uratuje, to jednak zostawi wrażenie, żeśmy serio sprawy brali i przemówi ostrzegająco do społeczeństwa. Potrzeba było, by komitet biskupów pozostał w permanencji aż do ustawy - już to samo zrobiłoby wrażenie - a nie rozjechał się co do jednego. O sobie nie mówię, bo sam nie miałem żadnego tytułu i unikam w ogóle wrażenia, że się do czegokol-

144 BBWR.

${ }_{145}$ Mszps pisany na 2 stronach formatu A4.

146 Wyraz podkreślony.

147 Aleksander Prystor (1874-1941) - działacz Polskiej Partii Socjalistycznej, jeden z przywódców Związku Walki Czynnej, minister pracy i opieki społecznej (1929-1930), następnie minister przemysłu i handlu (1930-1931), premier (1931-1933), poseł na sejm z listy BBWR (1930-1935), senator (1935-1939), marszałek senatu (1935-1938). W czasie drugiej wojny światowej aresztowany przez Sowietów, zmarł w więzieniu w Moskwie. J. Gołębiowski, Prystor Aleksander Błażej, w: Kto byt kim, s. 62-63.

148 BBWR. 
wiek mieszam, i [z] czymkolwiek narzucam. Ale inni księża biskupi byli od tego, a przede wszystkim Wasza Eminencja. Proszę darować, że tak szczerze mówię, ale zbyt wielką jest chwila, by cokolwiek owijać w bawełnę. Należałoby się też albo w formie skarcenia Czuja, co już spóźnione, albo w formie pochwały czy podziękowania posłom, którzy sprawy bronili zaznaczyć z naciskiem nasze stanowisko. Ale to są już rzeczy drugorzędne, wobec tej, która może jest jeszcze do zrobienia. Zresztą można zrobić i jedno, i drugie. Zresztą powinna była być natychmiast zwołana prawna komisja bodaj wtedy, kiedy list Prystora nadszedł. Nawet to zostało poniechane. Nie czas na spóźnione żale, dlatego proszę mi darować moje uwagi i proszę jeśli jest jeszcze czas, w ten czy w ów sposób sytuację ratować, a jeśli się nie da, to bodaj z godnością dla episkopatu postawić.

Łączę najoddańsze wyrazy czci najgłębszej

+ Teodorowicz

Krynica, 1/III/ [1]932

29.

ASIK, $A H$, t. V, cz. 28, s. 102, arcybp J. Teodorowicz do kard. A. Hlonda ${ }^{149}$.

Czwartek 28/IV [1]932

Będę zobowiązany Waszej Eminencji, jeśli mi Wasza Eminencja naznaczy czas i miejsce, bym mógł z Waszą Eminencją pewne sprawy omówić. Najoddańszy Arcybiskup Teodorowicz

30.

ASIK, $A H$, t. V, cz. 28, s. 108, kopia listu arcybpa J. Teodorowicza do kard. A. Hlonda ${ }^{150}$.

\section{Wasza Eminencjo!}

Jak widzę lata mają swoje prawa i nie wolno jest znowu bezkarnie równocześnie obrabiać życie Pana Jezusa ${ }^{151}$, Konnersreuth ${ }^{152}$, a na dobitkę Ś [więtego] Pawła w 4 konferencjach salzburskich ${ }^{153}$. Ponieważ na te ostatnie konferencje

149 Mszps pisany na 1 stronie formatu A4. Na marginesie nr telefonu: 256.01.

${ }_{150}$ Mszps pisany na 1 stronie formatu A4.

151 Arcybiskup Teodorowicz opracowywał wielotomowe dzieło dotyczące życia Chrystusa. Z zaplanowanych 12 woluminów drukiem ukazały się następujące: Od Betlejem do $\mathrm{Na}$ zaretu (1932), Od Jahwy do Mesjasza (1936), Herold Chrystusa na tle epoki (1937). Książki wydało Wydawnictwo św. Wojciecha w Poznaniu.

${ }^{152}$ Chodzi o pracę arcybiskupa J. Teod orowicza pt. Zjawiska mistyczne i ich tlumaczenia (Konnersreuth), Poznań 1933.

${ }^{153}$ Prawdopodobnie chodzi o publikację arcybiskupa J. Teodorowicza pt. Św. Pawet Apostot Narodów, „Prąd”, 17, 1930, 18, s. 209-232, 278-293. 
zużyłem Marienbad, więc zniszczywszy cały plon wypoczynku muszę ponosić skutki tego. Więc po przemęczeniu, rad nie rad ugrzęzłem w Gasteinie ${ }^{154}$, który się domaga jako tako zaokrąglonej kuracji i dlatego niestety nie pozwoli mi być ani na rekolekcjach, ani na Konferencjach w Gnieźnie. Żałuję tego ogromnie, ale istotnie jestem zbyt przemęczony, bym mógł sobie na nowe ryzyko pozwolić. Jeśli by już za późno było na oddanie komu innemu z Księży Biskupów mojego referatu, w takim razie zachowam go chętnie do przyszłej konferencji. Proszę tedy bardzo Waszą Eminencję o usprawiedliwienie mojej nieobecności.

Przy tej sposobności donoszę Waszej Eminencji, że Prałat Münch ${ }^{155}$ z Kolonii, kierownik ruchu młodzieży i organizator kursów salzburskich pragnąłby przybyć do Polski i mieć konferencję o stanie umysłów katolików w obecnych Niemczech. Jeśli go dobrze zrozumiałem, to powoływał się na to, że już mówił o tym z Waszą Eminencją i Wasza Eminencja miał się przychylnie odnieść do tego planu.

Całuję pierścień Waszej Eminencji i łączę najoddańsze wyrazy czci najgłębszej

+ Teodorowicz

Bad Gestein, Priestenhaus, 5/IX [1]932

31.

ASIK, $A H$, t. V, cz. 28, s. 113-114, arcybp J. Teodorowicz do kard. A. Hlonda ${ }^{156}$.

\section{Wasza Eminencjo!}

Prawdziwie wzruszył mnie Wasza Eminencja swą pamięcią o mnie i o mej pracy. Niesłychanie mi się przydadzą oba wycinki przysłane mi przez Waszą Eminencję, zwłaszcza ucieszyłem się informacją z artykułu Gerlicha ${ }^{157}$, iż interwencja moja u niego i u profesora Mutza ${ }^{158}$ odniosła pożądany skutek. Natarłem na nich obu bardzo silnie, ażeby u ojca Teresy Neumann ${ }^{159}$ wymogli zmianę jego

154 Bad Gastein - kurort w Wysokich Taurach w Austrii.

155 Franz Xaver Münch (1883-1940) - niemiecki duchowny katolicki wyświęcony w 1908 roku, sekretarz generalny znanego stowarzyszenia akademickiego Katholischer Akademikerverband, organizator kursów dla młodzieży, publicysta. Münch Franz Xaver, w: Deutsche Biographische Enzyklopädie (dalej: DBE), 7, München 1998, s. 293.

156 Mszps pisany na 2 stronach formatu A4.

157 Fritz Gerlich (1883-1934) - niemiecki dziennikarz i publicysta, działacz antyhitlerowskiej opozycji, autor prac na temat Teresy Neumann, w 1931 roku nawrócił się na katolicyzm, zamordowany przez niemieckich nazistów w Dachau. Gerlich Fritz (Albert), w: DBE, 3, München 1996, s. 651.

158 Postać niezidentyfikowana.

159 Teresa Neumann (1898-1962) - niemiecka stygmatyczka i mistyczka mieszkająca w Konnersreuth w Bawarii. C. Köppl, Neumann Therese (Resl) von Konnersreuth, w: Neue Deutsche Biographie, 19, Berlin 1999, s. 162-163. 
nieprzejednanego stanowiska ${ }^{160}$. Dotąd o tym nikomu nie mówiłem, ale skoro to już Gerlich ogłosił, to dziś mogę powiedzieć, że odpowiedź Neumanna, która nie jest negatywna, jest ratunkiem całej sytuacji. Ojciec Teresy niezawodnie postawił Episkopatowi warunki ze swej strony i należy się spodziewać, że jakiś kompromis przyjdzie do skutku. Udawał się do mnie Kaczyński z tą sprawą, być więc bardzo może, że coś o tym napisze.

Tu mam wiele bardzo kłopotów skutkiem zajść młodzieży związanych z zamordowaniem jednego $\mathrm{z}$ nich przez żyda ${ }^{161}$; mam jednak nadzieję, że uda się młodzież uchronić przed nieopatrznymi i bardzo dla niej szkodliwymi krokami. Był tu Rostworowski ${ }^{162}$, redaktor „Dnia Polskiego" ${ }^{163}$ z odczytem, w którym zaatakował Episkopat, mówiąc, że chociaż odbywa konferencję w Warszawie, to jednak nie uznał za stosowne odezwać się w sprawie młodzieży. O młodzieży wyrażał się jak najgorzej; w godzinę po jego odczycie już się ukazała odezwa nasza. Po odczycie sami członkowie jego klubu uprosili księdza Ciemniewskiego $^{164}$, aby zabrał głos w dyskusji. Ten w grzecznej bardzo formie, ale dał panu Rostworowskiemu ciętą odprawę. Powiedział mu, że Księża Biskupi mają różne sposoby wpływania na sytuację, jak na przykład w tym wypadku na młodzież, które nie muszą być koniecznie zaraz publiczne i dlaczego uważa za wysoce niewłaściwe atakowanie Episkopatu za to, co się komuś dla braku głębszej znajomości sprawy nie podoba.

${ }^{160}$ Chodzi o wyrażenie zgody na przeprowadzenie specjalistycznych badań lekarskich Teresy Neumann.

161 Pisownia zgodna $\mathrm{z}$ oryginałem.

162 Wojciech Rostworowski (1877-1952) - prawnik i ziemianin związany z Narodową Demokracją, należał do Ligi Narodowej, Stronnictwa Demokratyczno-Narodowego, Stronnictwa Narodowego, angażował się w wydawanie prasy, działalność społeczną między innymi w zarządzie Towarzystwa Polskiej Macierzy Szkolnej, członek Tymczasowej Rady Stanu, od 1927 roku należał do Polskiej Powszechnej Spółki Wydawniczej wydającej między innymi „Dzień Polski”, którego był redaktorem, w 1930 i 1935 roku wybrany senatorem RP, po drugiej wojnie światowej zaangażował się w pracę literacką i publicystyczną. J. Molenda, Rostworowski Wojciech Hilary, w: Polski słownik biograficzny, 32, Wrocław-Warszawa-Kraków 1989, s. 246-251.

163 „Dzień Polski” - dziennik wydawany w Warszawie od 1924 roku, odgrywał rolę jednego z najważniejszych organów prorządowego ugrupowania zachowawczego. J. Łojek, J. Myśliński, W. Władyka, Dzieje prasy polskiej, Warszawa 1988, s. 100.

164 Jan Ciemniewski (1866-1947) - kapłan archidiecezji warszawskiej, święcenia kapłańskie otrzymał w 1893 roku, doktor filozofii Uniwersytetu Gregoriańskiego w Rzymie, publicysta i pedagog, wykładowca etyki w Seminarium Duchownym w Detroit; po powrocie do kraju pracował duszpastersko w archidiecezji lwowskiej obrządku łacińskiego, w celu walki z alkoholizmem założył Polską Ligę Przeciwalkoholową (1927); autor publikacji z zakresu pedagogiki. K. Jędrzejczak, Ciemniewski Jan, w: Stownik pedagogów polskich, red. W. Bobrowska-Nowak, D. Drynda, Katowice 1998, s. 39-40. 
Wywlekanie na forum publiczne jednej ze spraw broszury Łubieńskiego ${ }^{165}$ uważa ksiądz Ciemniewski również za wysoce niewłaściwe, bo należało by tę sprawę załatwić z Nuncjaturą, a nie używać jej jako środka krytyki. Co do oskarżenia młodzieży, której odbierają autonomię uniwersytetu, której nie dopuszczają do niego nakładając na nią wielkie taksy, chyba aż za nadto wiele okazuje cierpliwości; nie w niej, ale poza nią trzeba szukać przyczyny złego.

Pozwalam sobie dołączyć list i odezwę pana Sikorskiego ${ }^{166}$, która jest niezawodnie bardzo poczciwą i gorącą, ale wskutek „Cyrenejczyka i Weroniki” trochę osobliwa. Ja mu odpisałem, że się stosuję do jego życzenia i odsyłam odezwę tam, gdzie należy, jemu nie pisząc jednak bliżej, że ją odsyłam Waszej Eminencji.

Korzystam z tej sposobności, ażeby raz jeszcze Waszej Eminencji podziękować i przesyłam nieurzędowe wprawdzie, ale bardzo gorące i bardzo oddane życzenia świąteczne.

Całuję pierścień Waszej Eminencji w najgłębszej czci

+ Teodorowicz

Lwów, dnia 14 grudnia 1932

Tu w sprawie młodzieży zupełnie potracili głowy. Zamiast tych, którzy na skutek odezwy naszej ${ }^{167}$ powstrzymali strajk wyszczególnić, zrobiono wręcz odwrotnie i właśnie tych ludzi więżą i trzymają. Z godziny na godzinę ferment młodzieży właśnie dlatego wzrasta.

165 Chodzi o broszurę Droga na Wschód Rzymu (Warszawa 1932) Henryka Ignacego Łubieńskiego (1901-1960), publicysty konserwatywnego związanego z obozem sanacji. Broszura zawierała krytykę akcji neounijnej w Polsce i już w kilka tygodni po opublikowaniu została obłożona interdyktem przez kardynała Kakowskiego (3 października 1932), podtrzymanym przez papieża Piusa XI. Miała jednak wielu obrońców, również w sferach katolickich, gdyż ujawniała fatalny stan stosunków wewnętrznych w Kościele greckokatolickim. C. Lechicki, Łubieński Henryk Ignacy, w: Polski słownik biograficzny, 18, Wrocław-WarszawaKraków 1973, s. 484-485.

166 Być może chodzi o Władysława Sikorskiego (1881-1943), generała Wojska Polskiego, premiera i ministra spraw wewnętrznych (1922-1923), szefa Generalnego Inspektoratu Piechoty (1923-1924), następnie ministra spraw wojskowych, który podczas rządów sanacji znajdował się na marginesie polityki i wspierał opozycję.

167 Prawdopodobnie: Odezwa J[ego] Em[inencji] Ks. Kardynała Prymasa w sprawie „, Święta Młodzieży”, „MK”, 47, 1932, 10, s. 89. 
32.

ASIK, $A H$, t. IV, cz. 21, s. 63, arcybp J. Teodorowicz do kard. A. Hlonda ${ }^{168}$.

\section{Wasza Eminencjo!}

Bardzo dziękuję za list pasterski ${ }^{169}$ najłaskawiej mi przesłany. Po raz pierwszy spotykam się z ujęciem parafii w tak nowoczesnym duchu, na tak szerokim podłożu w związku i z ruchem liturgicznym, i z akcją katolicką. Należy się Waszej Eminencji istotnie gorąca podzięka za ten podarunek dla Kościoła w Polsce.

Korzystam ze sposobności, ażeby udzielić Waszej Eminencji małej ploteczki. Założyłem się z księdzem biskupem Przeździeckim w Krynicy o to, czy Wasza Eminencja do Rzymu pojedzie, czy też nie pojedzie. Ja twierdziłem, że nie, on zaś na pewno, że tak. Dzięki Bogu, że przegrał, bo Bogiem a prawdą byłem bardzo zaniepokojony nie o mój zakład, ale o brak nominacji na prefekta propagan$\mathrm{dy}^{170}$. Na szczęście dziś ta rzecz jest już przesądzona.

Przy tej sposobności jeszcze raz dziękuję Waszej Eminencji za posyłki w sprawie Konnersreuth; już mam gotową odpowiedź O. Siwkowi ${ }^{171}$, którą w tych dniach drukuję.

Pisał do mnie prałat Münch, że chce tu przyjechać w sprawie Adama ${ }^{172}$; przyjeżdża z aktami i chce mię odwiedzić. Ale tu najmniej o mnie chodzi, bo trzeba przede wszystkim, by się zobaczył z Waszą Eminencją. Dlatego gdyby Wasza Eminencja był łaskaw donieść mi w paru słowach, kiedy będzie w Poznaniu a kiedy wyjeżdża do Rzymu, to byłbym bardzo zobowiązany, bo bym mu to zaraz zakomunikował.

${ }^{168}$ Mszps pisany na 1 stronie formatu A4. Kopia listu: FKiDOP, t. 130, sygn. 1386/420 (12) [7], s. 1-2.

169 A. Hlond, O życiu parafialnym. Wielkopostny list pasterski, Poznań, 1 marca 1933.

170 Kongregacja Rozkrzewiania Wiary w Rzymie.

171 Paweł Siwek (1893-1986) - jezuita, święcenia kapłańskie otrzymał w 1922 roku, doktor teologii i filozofii, wykładowca matematyki w gimnazjum w Chyrowie (1916-1919), profesor filozofii w studium zakonnym w Nowym Sączu (1923-1924) i Krakowie (1929-1931), na Uniwersytecie Gregoriańskim w Rzymie (1931-1939), Wydziale Katolickim w Rio de Janeiro (1940-1946), Uniwersytecie Fordham w Nowym Jarku (1946-1960), Uniwersytecie Laterańskim w Rzymie (1960-1975); w pracy naukowej zajmował się głównie psychologią filozoficzną, psychologią doświadczalną i parapsychologią, opublikował także dwie książki poświęcone Teresie Neumann: Konnersreuth w świetle nauki i religii (Kraków 1931), Metody badań zjawisk nadprzyrodzonych. Problem Konnersreuth (Kraków 1933). Encyklopedia wiedzy o juzuitach, s. 619.

${ }^{172}$ Karl Adam (1876-1966) - niemiecki teolog, dogmatyk, profesor uniwersytetów w Monachium, Strasburgu i Tybindze; autor tłumaczonej na wiele języków książki o istocie katolicyzmu: Das Wesen des Katholizismus (Augsburg 1924); członek partii nazistowskiej. Adam Karl, w: DBE, 1, München 1995, s. 29. 
Tymczasem jeszcze raz dziękując Waszej Eminencji łączę najoddańsze wyrazy czci najgłębszej

+ Teodorowicz

Lwów, dnia 22 marca 1933

33.

ASIK, $A H$, t. IV, cz. 21, s. 64, kard. A. Hlond do arcybpa J. Teodorowicza ${ }^{173}$.

Ekscelencjo!

Dziękuję za miły list. Wyjeżdżam do progów apostolskich prawdopodobnie w poniedziałek wielkanocny. Chętnie rozmówiłbym się z ks. prałatem Münchem co do książki prof. Adama.

Ubawiła mnie ploteczka. Ten ktoś volentibus et nolentibus ${ }^{174}$ głosił moje osiedlenie się w Rzymie. Zostaję jeszcze długie lata.

Niespokojny jestem o zdrowie Księcia Metropolity. Chyba wkrótce zmoże chorobę i wróci do pracy.

Łączę wyrazy najgłębszej czci i oddania. Waszej Ekscelencji powolny sługa i brat w Chr[ystusie].

$$
\begin{array}{r}
\text { H1[ond] } \\
\mathrm{P} \text { [oznań], d[nia] 25/3 [19]33 }
\end{array}
$$

34.

FKiDOP, t. 136, sygn. 1411/420 (12) [7], s. 35, arcybp J. Teodorowicz do kard. A. Hlonda ${ }^{175}$.

Wasza Eminencjo!

Czując jeszcze skutki wielkotygodniowego zaziębienia, nie mogę niestety, ryzykować podróży do Warszawy w tym zwłaszcza zmiennym czasie i nieopalanych wagonach.

Co do projektu konferencji to przedstawiam dwie sprawy: jedną jest uregulowanie kazań przez radio na wzór zagranicy. Ta kwestia już była poruszana, ale do formalnej decyzji jeszcze nie doszło. Druga kwestia to zastanowienie się nad sposobami przeciwdziałania zgubnej robocie Boya ${ }^{176}$, który zyskuje w kołach literatów nawet coraz szerszy zastęp zwolenników.

${ }^{173}$ Mszps pisany na 1 stronie formatu A4.

174 Łac.: chcąc nie chcąc.

175 Mszps pisany na 1 stronie formatu A4.

176 Tadeusz Żeleński Boy (1874-1941) - polski pisarz, poeta, tłumacz literatury francuskiej, krytyk Kościoła katolickiego i etyki katolickiej; w 1931 roku w tygodniku „Wiadomości Literackie” opublikował artykuł pt. Nasi okupanci krytykujący episkopat i prymasa Hlonda. 
Całuję pierścień Waszej Eminencji i łączę wyrazy mojej czci najgłębszej ${ }^{177}$ Lwów, dnia 18 kwietnia 1933

35.

FKiDOP, t. 130, sygn. 1382/185 [4], s. 3, arcybp J. Teodorowicz do kard. A. Hlonda' ${ }^{178}$.

Wasza Eminencjo!

W uprzejmej odpowiedzi na łaskawe pismo i wezwanie, ażebym wyznaczył delegata do Akcji Katolickiej, czynię temu wezwaniu zadość, przedstawiając do tej roli ks. Adama Bogdanowicza ${ }^{179}$.

Łączę wyrazy najgłębszej czci ${ }^{180}$

Lwów, dnia 27 listopada $1933^{181}$

36.

FKiDOP, t. 130, sygn. 1598/184 [7], s. 7-8, arcybp J. Teodorowicz do kard. A. Hlonda ${ }^{182}$.

\section{Wasza Eminencjo!}

Bardzo mnie ucieszyły przysłane mi słowa Waszej Eminencji o mojej książce ${ }^{183}$, które sobie szczególniej cenię.

Jezuici jednak nie dają za przegraną. Posłużyli się ks. biskupem Przeździeckim, który mi w tajemniczy sposób dawał do poznania, iż z pewnych kół mu doniesiono o mych zamiarach thumaczenia mej książki na język niemiecki i że w takim razie domagano by się ode mnie, abym powiedział jakie mam zarzuty przeciw Siwkowi contra doctrina christianam ${ }^{184}$.

Oświadczył mi swą gotow[o]ść pośrednictwa i pomocy, nie mówiąc jednak między kim ma być to pośrednictwo. Odpowiedziałem mu, że za jego gotowość

177 Brak podpisu.

178 Mszps pisany na 1 stronie papieru formatu A4.

179 Adam Bogdanowicz (1898-1941) - kapłan archidiecezji lwowskiej obrządku ormiańskokatolickiego, święcenia kapłańskie otrzymał w 1920 roku, wybitny kaznodzieja i rekolekcjonista młodzieży, katecheta w żeńskich szkołach średnich we Lwowie, sekretarz arcybiskupa Teodorowicza i kanclerz kurii ormiańskiej, kanonik ormiańskiej kapituły katedralnej (od 1933), w czasie drugiej wojny światowej zaangażowany w działalność Związku Walki Zbrojnej; zamordowany przez Sowietów w czerwcu 1941 roku. T. Krzyżowski, Archidiecezja lwowska, passim.

180 Brak podpisu.

181 Pod datą: „J[ego] Em[inencja] Kardynał Prymas August Hlond Poznań”.

182 Mszps pisany na 3 stronach cienkiego papieru formatu A4.

183 J. Teodorowicz, Zjawiska mistyczne i ich thmaczenia.

184 Łac.: przeciwko doktrynie chrześcijańskiej. 
i dobrą chęć serdecznie dziękuję, ale na tak ogólnikowych oświadczeniach nie mogę uczynić żadnego konkretnego kroku nie wiedząc właściwie o co sprawa idzie, kto to jest, kto b[is]k[u]p[owi] Przeździeckiemu o tych sprawach mówił, między kim właściwie on ma pośredniczyć. Odpisał mi jeszcze bardziej tajemniczo i zagadkowo, ale mimo woli się przyznał, skąd to wszystko poszło, bo mnie skierował do Generała OO. Jezuitów.

Prawdopodobnie chciano wybadać, czy ja się noszę z zamiarem thumaczenia mej książki na język niemiecki. Trzeba jednak wiedzieć Waszej Eminencji, że w Niemczech jest w kursie intensywnie propagowana przez litografowanie broszura O. Siwka. Dotarła ona dziś do kół racjonalistycznych i protestanckich, które $\mathrm{z}$ tego robią wielką propagandę przeciwko XX. Biskupom i Kościołowi. Nie mam jeszcze w ręku tekstu pisma Związku protestanckiego w którym ten artykuł się pojawił, ale obiecano mi z Niemiec pismo to przysłać.

Równocześnie uderzają na mnie Jezuici na szpaltach I[ustrowanego] K[uriera] C[odziennego $]^{185}$, w którym się pojawiają artykuły pisane przez O. Siwka, jak to po stylu jego poznać, z których jeden nazywa mnie fideistą, a więc zarzuca mi prawie herezję. Teraz świeżo znowu pojawia się zapowiedź odpowiedzi O. Siwka, znowu z ukłuciem mnie w zwrocie: o entuzjastach Konnersreuth.

Przy tej sposobności polecam Waszej Eminencji O. Kuleszęę ${ }^{186}$ który prosił mnie o to, ażebym go zalecił Waszej Eminencji, gdyż chce wstąpić do Salezjanów. Był on dotąd w Zgromadzeniu Marianów i kierował gimnazjum całym pod Warszawą. Nie widział jednak żadnej przyszłości w tym Zgromadzeniu. Otóż jest znakomity człowiek, przy tym uczony niepośledniej miary, znawca znakomity mistyki, którego pisma są cytowane w katolickiej encyklopedii francuskiej i przez Lagrange'a ${ }^{187}$. Sam jest wewnętrznie uduchowiony, a jak widać, posiada przy tym praktyczne organizacyjne zdolności; byłby to więc istotnie najlepszy nabytek dla Salezjanów.

185 „Ilustrowany Kurier Codzienny” - wysokonakładowy dziennik polityczno-informacyjny wydawany w Krakowie przez Mariana Dąbrowskiego, ukazywał się w latach 19101939. M. Jakubek, Prasa krakowska, s. 107.

186 Eugeniusz Kulesza (1891-1941) - święcenia kapłańskie otrzymał w 1921 roku w zgromadzeniu marianów, doktor teologii (1924), od 1930 roku pracował jako wychowawca i wykładowca w Kolegium Księży Marianów na Bielanach w Warszawie, w 1936 roku został rektorem Kolegium, w 1935 roku, uzyskawszy zgodę władz kościelnych, przeszedł do paulinów, po kilku dniach pobytu na Jasnej Górze wrócił jednak do dawnego zgromadzenia; w 1938 roku został przełożonym domu zakonnego w Drui, zamordowany przez Sowietów w czasie drugiej wojny światowej. J. Bukowicz, Świadkowie wiary. Marianie prześladowani przez hitleryzm i komunizm, Warszawa 2001, s. 138-148.

187 Reginald Garrigou-Lagrange (1877-1964) - francuski dominikanin, filozof i teolog, jeden z najwybitniejszych neotomistów XX wieku, wykładowca teologii fundamentalnej i dogmatycznej na Papieskim Uniwersytecie św. Tomasza z Akwinu w Rzymie (1909-1960); głośny przeciwnik modernizmu. K. Klauza, Garrigou-Lagrange Reginald, w: EK, 5, Lublin 1989, kol. 873-874. 
Osobno dołączam jeszcze odpowiedź na poruszone ongi przez ks. Kubinę ${ }^{188}$ kwestię dotacji mej diecezji w związku z programem, który widzę wyszczególniony w programie konferencji. Posyłam Waszej Eminencji na wypadek, gdyby zaszła aktualna tego potrzeba.

Wobec tego, że Rząd jednym Biskupom dał pełną dotację, a drugim zupełnie nic nie daje wnoszę, że może chce nas w ten sposób podzielić. Wasza Eminencja sam o tym najlepiej będzie wiedział jak ważną jest rzeczą, ażeby w tej sprawie zasadniczej XX. Biskupi stanęli bardzo silnie i bardzo energicznie. Jeżeli się uda Rządowi jeden wyłom uczynić, to wtedy w ogóle z tymi dotacjami przepadliśmy zupełnie.

Łączę przy tej sposobności dla Waszej Eminencji wyrazy najoddańsze i najgłębsze czci ${ }^{189}$

Lwów, dnia 1 grudnia 1933

P.S. Dołączam jeszcze Waszej Eminencji list ${ }^{190}$ prałata Schoepfera $^{191} \mathrm{w}$ sprawie beatyfikacji arcyksiężnej Magdaleny ${ }^{192}$. Z góry mu odpisałem, że wobec zbierania składek na beatyfikację królowej Jadwigi ${ }^{193}$, trudno dziś liczyć na Polskę w tej kwestii, tym bardziej, że ta księżna Habsburska zupełnie nikomu dotąd znaną nie była. W każdym razie składam ten list w ręce Waszej Eminencji do łaskawego rozstrzygnięcia.

188 Teodor Kubina (1880-1951) - święcenia kapłańskie otrzymał w 1906 roku we Wrocławiu, doktor filozofii i teologii, duszpasterz w Mikołowie, Chorzowie, Berlinie i Katowicach, aktywny działacz chrześcijańskich związków zawodowych, ordynariusz diecezji częstochowskiej (1926-1951). P. Nitecki, Biskupi Kościoła w Polsce, s. 233-234.

189 Brak podpisu.

190 Załącznik do listu nie zachował się.

191 Aemilian Schoepfer (1858-1936) - austriacki duchowny katolicki wyświęcony w 1880 roku, wykładowca Starego Testamentu i języków orientalnych w seminarium duchownym w Brixen, założyciel partii chadeckiej w Tyrolu, a także wydawnictwa, polityk, publicysta. Schoepfer Aemilian, w: DBE, 9, München 1998, s. 101.

192 Arcyksiężniczka Magdalena (1532-1590) - córka cesarza Ferdynanda I Habsburga i Anny Jagiellonki (z linii węgierskiej); założycielka zakonnej wspólnoty żeńskiej w Hall w Tyrolu; zmarła w opinii świętości. Habsburg Magdalena, w: Biographisches Lexikon des Kaiserthums Oesterreich, 7, Wien 1861, s. 1-2.

193 Jadwiga Andegaweńska (1374-1399) - koronowana w 1384 roku na króla Polski, w 1386 roku wyszła za mąż za księcia litewskiego Jagiełłę, przyczyniając się w ten sposób do chrystianizacji Litwy; kanonizowana w 1997 roku przez Jana Pawła II w Krakowie. R. Zawadzki, Święta Jadwiga Andegaweńska, „Folia Historica Cracoviensia”, 15/16, 2009/2010, s. 101-110. 
FKiDOP, t. 136, sygn. 1597/184 [7], s. 18-20, arcybp J. Teodorowicz do kard. A. Hlon$\mathrm{da}^{194}$.

\section{Wasza Eminencjo!}

Bardzo dziękuję za list łaskawy, a przy tym odpisuję na przedostatni list Waszej Eminencji w sprawie Niepokalanek. Wasza Eminencja dotknął istotnie zasadniczej kwestii, zapytując czy w ogóle dalsza wizytacja u Niepokalanek jest wskazana.

Otóż po rozwadze głębokiej i po rozmowie z księdzem arcybiskupem Twardowskim uważam, że dalsza wizytacja Niepokalanek zupełnie jest bezcelowa, a nawet szkodliwa. Przypominam sobie, że jeszcze przed dziesięciu, albo i więcej laty pierwszy wizytator o. Sobolewski ${ }^{195}$ już mi mówił, iż myśli wizytację zakończyć; sądzę, że gdyby był dłużej żył, byłoby się to i stało. Wprawdzie rozgniewało go to bardzo, że poza jego plecami z Rzymu poczęły przychodzić pewne urgensy także o zakończenie tej wizytacji i to go podnieciło niekorzystnie dla Zgromadzenia, ale to rzeczy nie zmienia. To pewne, że tak mi mówił; nawiasem dodam, że miał podejrzenie na Niepokalanki, jakoby one były przyczyną tych właśnie nalegań ze strony Rzymu. To było jednak niesłuszne ${ }^{196}$. Ja bowiem wiem dobrze, kto to zrobił.

Zaczyna po nim wizytację O. Trzemeski ${ }^{197}$. Ten człowiek najmniej się nadawał na wizytatora, ale ostatecznie uporządkował zewnętrzne sprawy Zgromadzenia. Formalista jakim on jest, dbał przede wszystkim o to, ażeby dekretami uzasadnić, kto właściwie jest założycielem Zgromadzenia, jaki tytuł przysługuje

${ }^{194}$ Mszps pisany na 3 stronach formatu A4.

195 Marian Sobolewski (1864-1922) - franciszkanin konwentualny, święcenia kapłańskie otrzymał w 1888 roku, uzyskał doktoraty z teologii i filozofii, wykładowca i wychowawca w studium zakonnym w Krakowie, od 1904 roku prokurator generalny zakonu i postulator misji, następnie prowincjał (1914-1918), gwardian klasztoru w Krakowie oraz wizytator Zgromadzenia Sióstr Niepokalanego Poczęcia NMP (1918-1921). J. Bar, Sobolewski Marian Jan, w: Słownik polskich pisarzy franciszkańskich (bernardyni i franciszkanie ślascy, franciszkanie konwentualni, klaryski oraz zgromadzenia III reguty) (dalej: SPPF), red. H. E. Wyczawski, Warszawa 1981, s. 446-447.

196 Zdanie dopisane odręcznie.

197 Emanuel Trzemeski (1879-1968) - redemptorysta, święcenia kapłańskie otrzymał w 1903 roku, w zgromadzeniu pełnił szereg ważnych funkcji, między innymi wykładowcy i wychowawcy niższego seminarium w Tuchowie (1906-1918), prowincjała polskiej prowincji redemptorystów (1918-1933), rektora klasztoru w Toruniu, a także wizytatora żeńskich zgromadzeń zakonnych, w tym Zgromadzenia Sióstr Niepokalanego Poczęcia NMP (19211930). P. Kurlenda, Trzemeski Emanuel, w: Toruński słownik biograficzny, red. K. Mikulski, 1, Toruń 1998, s. 237-238. 
M[atce] Karskiej ${ }^{198}$ i M[atce] Darowskiej ${ }^{199}$ etc. Ale trzeba powiedzieć, że pod względem formalnym, począwszy od reguły a skończywszy na drobnostkach wszystko zostało zrobione, co tylko zrobić było można. Cenzurę pism M[atki] Darowskiej zleciła Kongregacja ks. arcybiskupowi Twardowskiemu, który mnie o to prosił, bym tę cenzurę przeprowadził i to się też już stało.

Pamiętam, że kiedy przed kilku laty byłem w Rzymie, to wtedy poprzednik ${ }^{200}$ dzisiejszego kardynała Lepicier ${ }^{201}$ już mi mówił, że myśli zakończyć wizytację, że uważa ją za niepożądaną i nazwał Trzemeskiego człowiekiem nieodpowiednim i twardym (duro) ${ }^{202}$.

Tymczasem zaczęły i to ze samego Zgromadzenia iść skargi do samego papieża, które spowodowały dalszy ciąg wizytacji opartej już o osobiste niedowierzanie samego papieża a nawet daleko idące jego obawy co do tego Zgromadzenia. Znam te zarzuty i wiem, jak one były nieuzasadnione. A więc znowu kilkuletnia wizytacja dalsza była spowodowana nie realną potrzebą Zgromadzenia, ale po prostu donosami. Dzisiejszy wizytator pomimo wszystko jest człowiekiem praktycznym i realnym, i on już postawił kropkę nad ,i”, i pod każdym względem dokończył wizytację. Wszelka dalsza wizytacja jest już choćby z tego względu dla Zgromadzenia niepożądana, iż Zgromadzenie to nie może mieć dostatecznej liczby nowicjuszek, gdyż spowiednicy odradzają od wstępowania do Zgromadzenia, które uważają skutkiem trwającej wizytacji za nieuporządkowane. Myślę przy tym, że i Franciszkanie zechcą ratować honor swego wizytatora w ten sposób, by on właśnie zakończył wizytację. Kto wie, czy i nuncjusz zaangażowawszy się za wizytatorem ${ }^{203}$ już dla osobistych powodów, nie będzie szedł po tej samej linii.

198 Józefa Maria Karska (1823-1860) - współzałożycielka Zgromadzenia Sióstr Niepokalanego Poczęcia NMP i pierwsza przełożona generalna, służebnica Boża. H. Ko syra-Cieślak, Krzyżami zdobyłeś serce moje. Matka Józefa Karska niepokalanka 1823-1860, Szymanów 2002.

199 Marcelina Darowska (1827-1911) - współzałożycielka Zgromadzenia Sióstr Niepokalanego Poczęcia Najświętszej Maryi Panny (1857), przełożona generalna zgromadzenia (1860-1911), powołała do istnienia wiele szkół i placówek oświatowych dla dziewcząt, jej uroczystościom pogrzebowym w Jazłowcu przewodniczył arcybiskup Teodorowicz; beatyfikowana w 1996 roku. A. Kinasz, Błogosławiona Marcelina Darowska-życie i działalność w stużbie Bogu, ojczyźnie, społeczeństwu, „Folia Historica Cracoviensia”, 15/16, 2009/2010, s. 375-390.

200 Prawdopodobnie kardynał Camillo Laurenti (1861-1938), który pełnił obowiązki prefekta Kongregacji ds. Zakonów w latach 1922-1928.

201 Alexis-Henri-Marie Lépicier (1863-1936) - święcenia kapłańskie otrzymał w 1885 roku, wizytator apostolski w Indiach, od 1927 roku kardynał, prefekt Kongregacji ds. Zakonów w latach 1928-1935.

202 Wł.: twardy.

203 Wyraz dopisany odręcznie. 
$\mathrm{W}^{204}$ razie jednak, gdyby wizytacja się zakończyła, potrzebuje jednak Zgromadzenie porady i kierunku wytrawnego człowieka. To mi mówiła niedawno sama Matka Generalna ${ }^{205}$ : w tej roli na ten wypadek Zgromadzenie pragnęłoby mieć ks. Brossa ${ }^{206}$.

Tak się przedstawia stan rzeczy: wiem, że Wasza Eminencja obarczona pracą nie ma czasu na czytanie, ale gdyby kiedy znalazł gdzieś na wywczasach wolną chwilę, to proszę rzucić okiem na mój list, który pisałem do poprzedniego wizytatora Trzemeskiego w sprawie Niepokalanek. Z tego listu - sądzę - Wasza Eminencja będzie mógł się dowiedzieć o pewnych szczegółach historii, pod wieloma względami niefortunnej tej, przewlekłej tyloletniej wizytacji.

Całując pierścień Waszej Eminencji, łączę wyrazy mej czci najgłębszej, zawsze oddany

+ Teodorowicz ${ }^{207}$

Lwów, dnia 15 stycznia 1934

38.

FKiDOP, t. 140, sygn. 976/420 (8) [7], s. 7-8, kard. A. Hlond do arcybpa J. Teodorowicza ${ }^{208}$.

Poznań, dnia 16 stycznia 1934

Ekscelencjo!

Dziękuję za łaskawy list z dnia 1 grudnia i za informacje o dalszym przebiegu sprawy z O. Siwkiem. W międzyczasie prosił mnie O. Ledóchowski o pośrednictwo, bo mu na tym zależy, by polemikę zakończyć. Jedyny punkt z pism Waszej Ekscelencji, który chciałby wyjaśnić, to zarzut racjonalizmu, który tak ogólnie postawiony, O. Siwka jako profesora Uniwersytetu Papieskiego dyskwalifikuje.

204 Od tego momentu fragment do końca listu przekreślony.

${ }^{205}$ Chodzi o matkę Zenonę Ludwikę Dobrowolską (1879-1956), przełożoną generalną Zgromadzenia Sióstr Niepokalanego Poczęcia NMP (1933-1953). Informacje uzyskane od s. Janiny Martynuski CSIC, Szymanów, 15 stycznia 2015 roku.

206 Stanisław Bross (1895-1982) - święcenia kapłańskie otrzymał w 1919 roku w Gnieźnie, doktor teologii i prawa kanonicznego, dyrektor Naczelnego Instytutu Akcji Katolickiej (1929-1939), w czasie drugiej wojny światowej więziony w Dachau, po wojnie pełnił funkcję referenta w sekretariacie prymasa Polski, kanonik kapituły prymasowskiej w Gnieźnie (19491962), wikariusz generalny archidiecezji gnieźnieńskiej (1953-1956), redaktor kilku czasopism katolickich, między innymi „Ruchu Katolickiego”, „Kultury”, „Misterium Christi”. Kanonicy kapituly katedry Gnieźnieńskiej 1918-2009, red. B. Czyżew ski, K. Wętkowski, Gniezno 2010, s. 161-163.

207 Własnoręczny podpis autora listu.

208 Mszps pisany na 2 stronach papieru formatu A4. W lewym górnym rogu wydrukowany napis: „Prymas Polski”; w lewym dolnym rogu adresat: „J[ego] Eksc[elencja] Najprzewielebniejszy Ks. Arcybiskup Teodorowicz, Arcybiskup Lwowski obrz. orm. Lwów”. 
Już o tym wspomniałem w Warszawie J[ego] Eksc[elencji] Księciu Metropolicie Sapieże, by przy spotkaniu się z Waszą Ekscelencją poruszył tę sprawę. Niezależnie od tego piszę o tym Waszej Ekscelencji, zaznaczając, że nie bardzo wiem, jak się do tego pośrednictwa zabrać. Będę Waszej Ekscelencji bardzo wdzięczny za łaskawą informację, czy Wasza Ekscelencja godzi się na to, bym ja w tej roli wszedł w sprawę i jakby zdaniem Waszej Ekscelencji polemikę można zakończyć. Służę chętnie, ale nie chciałbym się narzucać.

O sprawie O. Kuleszy pomówię z Księżmi Salezjanami. Podzielam zupełnie zdanie Waszej Ekscelencji co do zbiórki w Polsce na beatyfikację arcyksiężnej austriackiej Magdaleny. Nikt by u nas tego nie zrozumiał. Mamy dosyć swoich kandydatów, których procesy głównie z powodu braku środków nie poruszają się naprzód.

Słyszę, że Ekscelencja wybiera się do Krynicy. Życzę pomyślnej kuracji i wytchnienia.

Z najgłębszą czcią i oddaniem + August Kard. Hlond ${ }^{209}$

39.

FKiDOP, t. 130, b. sygn., s. 10-11, arcybp J. Teodorowicz do kard. A. Hlonda ${ }^{210}$.

\section{Wasza Eminencjo!}

Piszę trzeci list zupełnie poufny do Waszej Eminencji, który jest praktycznym dopowiedzeniem do listu w sprawie O. Siwka. Po napisaniu już listu do Waszej Eminencji przyszła mi myśl, którą się z Waszą Eminencją dzielę. Dowiedziałem się teraz właśnie, że O. Siwek wykończył manuskrypt będący odpowiedzią na ostatnią moją książkę, ale władze rzymskie zabroniły mu drukowanie tego manuskryptu. To będzie niezawodnie prawdą, bo mówił o tym superior OO. Jezuitów, zawsze doskonale o przebiegu tej sprawy poinformowany.

Otóż w tych warunkach skłaniałbym się bardziej niż kiedy do tego, by w jakiś sposób O. Generałowi dogodzić i przychodzi mi myśl następująca. Czy by to się przypadkiem nie dało uczynić przez wymianę listów między O. Generałem a mną, które by były ogłoszone na przykład w K[atolickiej] A[gencji] P[rasowej]. W liście swoim musiałby O. Generał dać mi moralne zadośćuczynienie $\mathrm{w}$ jakiejś formie; to jest warunek sine qua non ${ }^{211}$. Ja zaś z mej strony napisałbym list, w którym bym przytoczył te cytaty z moich prac, w których odcinałem zupełnie O. Siwka od jakichkolwiek podejrzeń o jego przekonaniach racjonalistycz-

209 Własnoręczny podpis autora listu.

${ }^{210}$ Mszps pisany na 2 stronach cienkiego papieru formatu A4. U góry dopisano odręcznie: „J[ego] E[minencja] X. Prymas I 1934”.

211 Łac.: konieczny, niezbędny warunek. 
nych; podniósłbym co najwyżej i bardzo lekko, że miałem na myśli materialne nieuświadomione stanowisko jego w stycznych punktach z racjonalizmem, ale nic ponadto. Kwestia zresztą bliższa formy, byłaby już sprawy do późniejszego ewentualnego ułożenia.

Poddaję osądzeniu Waszej Eminencji tę moją myśl, która mi się nasunęła i to pod wpływem rozmowy z ks. arcybiskupem Sapiehą, który tu u mnie bawił.

Jeszcze raz proszę przyjęć ode mnie zapewnienie o mej najgłębszej czci ${ }^{212}$ Lwów, dnia ${ }^{213}$ stycznia 1934

40.

FKiDOP, t. 130, b. sygn., s. 36-47, arcybp J. Teodorowicz do kard. A. Hlonda ${ }^{214}$.

\section{Wasza Eminencjo!}

Bardzo dziękuję Waszej Eminencji za list ostatni i najchętniej przyjmuję wszelkie pośrednictwo Waszej Eminencji w tej tak przykrej i bolesnej sprawie.

Jestem gotów pójść w zasadzie w granicach możliwości na wszelkie próby rozwiązania tego problemu, zwłaszcza głównie ze względu na osobę O. Generała, którego nie tylko wysoko cenię, ale dla którego osoby z dawien dawna mam szczególniejszy sentyment.

Ale nie tylko Wasza Eminencja, lecz i ja także nie wiem doprawdy, jak by się można do załatwienia tej sprawy wziąć. Czuję się obowiązany przedstawić Waszej Eminencji a pośrednio O. Generałowi te trudności, jakie dzisiaj są z tą sprawą połączone. Gdyby próba takiego pośrednictwa była podjęta rok temu przez O. Generała, zanim jeszcze O. Siwek napisał mi odpowiedź, wtedy w moim przekonaniu nie przedstawiałaby ona żadnych trudności. Albowiem wówczas była kwestia otwarta, czy na moją krytykę książki ${ }^{215} \mathrm{O}$. Siwka w Ateneum ${ }^{216}$ ma przyjść jakieś oświadczenie uzyskane drogą jakiejś interwencji, jak na przykład proponowanej dzisiaj, albo też czy kwestia ta ma być pchnięta na tory publicznej dyskusji naukowej. Przyznaję się Waszej Eminencji, że rok temu wstecz bardzo byłbym ucieszony tym projektem, który dziś przychodzi, nie tylko ze względu na mnie, na oszczędzenie mi roku pracy i wielkich wysiłków, ale i ze względu na

212 Brak podpisu.

213 Zostawione puste miejsce na wpisanie daty dziennej.

${ }^{214}$ Mszps pisany na 12 stronach papieru formatu A4. U góry dopisano odręcznie: „do X. Prymasa 31/I [1]934”.

${ }^{215}$ P. Siwek, Konnersreuth w świetle nauki i religii, Kraków 1931.

216 Właściwie: „Ateneum Kapłańskie” - miesięcznik powstały w 1909 roku z inicjatywy ks. Idziego Raszewskiego, redagowany przez zespół wykładowców seminarium duchownego we Włocławku, poświęcony studiom z różnych dziedzin teologii, między innymi Pismu św., dogmatyce, apologetyce, prawu kanonicznemu, historii i innych. Ukazuje się do dnia dzisiejszego. Bibliografia katolickich czasopism religijnych, s. 42. 
O. Generała, a nawet [na] samo Zgromadzenie ${ }^{217}$. Bo pisać książkę, jaką ja pisać musiałem w odpowiedzi O. Siwkowi, to było dla mnie istotnie ze względu na mój stosunek do O. Generała czymś bardzo bolesnym i moralnie bardzo dotkliwym. Niestety! O. Generał obrał wtedy drogę naukowej publicznej dyskusji, udzielając pozwolenia O. Siwkowi, ażeby mi odpowiedział.

Odpowiedź taka, jaką mi dał O. Siwek, zmusiła mnie mimo mej chęci i woli do wyczerpującej odpowiedzi, jaką mu dałem w znanej książce ${ }^{218}$. Wedle zdań wielu z XX. Biskupów, od których otrzymywałem listy, podług krytyk uczonych jakie się ukazały dotąd, wedle opinii zwłaszcza jednego zagranicznego pisarza ascetycznego i mistycznego, który po polsku rozumie, książka moja już jest ostatecznym i definitywnym załatwieniem na drodze naukowej sporu z O. Siwkiem.

Sądząc po tych różnych głosach, już O. Siwkowi nie pozostawało nic do odpowiedzi; albowiem nie mógł zaprzeczyć, że świadectwa moje o zjawiskach w Konnersreuth są bezpośrednie i naoczne, i tym samym pobijają jego świadectwa na niewidziane ${ }^{219}$. Nie mógł O. Siwek zaprzeczyć, że się dopuścił zupełnego zniekształcenia moich wszystkich tez rozwiniętych przeze mnie w „Ateneum”220, fałszując na całej linii moje myśli, albowiem udowodniłem mu to zestawieniem w dwóch kolumnach cytatów mojej pracy, a tłumaczeniem tych cytatów przez niego. Cytat zaś jest jak liczba w bilansie, która żadną argumentacją obalić się nie da.

Fałszerstwo więc moich idei - proszę darować ten drastyczny wyraz - jest ponad wszelką wątpliwość oczywiste, a popełnione zostało celowo i programowo z ogromnym sprytem i zręcznością; nie mógł w końcu O. Siwek zaprzeczyć, że jego druga praca wprowadzająca kryteria mistyczne ${ }^{221}$, była mimowolnym samooskarżeniem jego książki pierwszej, gdzie tych kryteriów był zupełny brak i gdzie wywody O. Siwka o zjawiskach mistycznych były jedynie oparte o analogie psychopatyczne.

Ale oczywiście wolno było być O. Siwkowi innego zdania i po ukazaniu się mojej książki zapowiedział on szumnie przez agenta swego ks. Weryńskiego ${ }^{222}$

217 Błąd autora; jezuici są zakonem, a nie zgromadzeniem.

218 J. Teodorowicz, Zjawiska mistyczne $i$ ich thumaczenia.

219 Pisownia zgodna $\mathrm{z}$ oryginałem.

220 J. Teodorowicz, Zjawiska mistyczne i ich tlumaczenia, „Ateneum Kapłańskie” (dalej: AT), 18, 1932, 29, s. 1-16, 105-121, 209-229, 313-338.

221 P. Siwek, Metody badań zjawisk nadprzyrodzonych: problem Konnersreuth, Kraków 1933.

${ }^{222}$ Henryk Weryński (1892-1984) - święcenia kapłańskie otrzymał w 1915 roku w Tarnowie, od 1920 roku był członkiem Stowarzyszenia Dziennikarzy Polskich; przedstawiciel Katolickiej Agencji Prasowej w Krakowie (1931-1939), po drugiej wojnie światowej angażował się w działalność publicystyczną i dziennikarską oraz w pracę społeczną i polityczną, od 1946 roku był kapelanem Wojska Polskiego; jego poglądy i działalność w okresie rządów komunistycznych spotkały się z krytyką władz kościelnych. Schematyzm diecezji tarnowskiej 
aż telegraficznie z Citta Vaticana w K[atolickiej] A[gencji] P[rasowej], że da mi odpowiedź. Również stylem reklamowym zapowiedziana została ta odpowiedź w „Ilustrowanym Kurierze Codziennym” przez ks. Weryńskiego pod pseudonimem „Miel”, iż mylą się wszyscy ci, którzy sądzą, że moja książka definitywnie załatwia się z O. Siwkiem. Właśnie nowa książka O. Siwka - pisał ów „,anonimowy teolog” - będzie istną rewelacją dla „entuzjastów Konnersreuth”. Jednym słowem w sposób zupełnie niebywałej reklamy w świecie naukowym, O. Siwek ogłasza urbi et orbi ${ }^{223}$, że mi da odpowiedź i to odpowiedź nie byle jaką, za którą stoi w każdym razie Gregorianum ${ }^{224}$.

W takich warunkach jakże ja mogę wystąpić z jakimś projektem od siebie, którego następstwem byłoby powstrzymanie odpowiedzi O. Siwka? Oznaczałoby to innymi słowy kapitulację przed nim, obawę przed jego książką, ale pomijając już te względy oznaczałoby to z mej strony, że po rozpoczętej dyskusji naukowej pragnę zamknąć usta mojemu oponentowi, czego nie mam prawa mu czynić. Ja mogę więc tylko stać na tym stanowisku, że skoro O. Siwek chce mi odpowiedzieć, to mu przyznaję wszelkie prawo do tej odpowiedzi i spokojnie wyczekuję jej pojawienia się. Takie stanowisko jest logiczną konsekwencją sporu, który został już raz wyniesiony przed forum publiczne. Można bardzo ubolewać, że tak się stało, to rzecz inna, ale skoro to się już stało, to dalszy rozwój i ostateczne rozegranie tej sprawy nie jest już w ręku moim, ale w ręku mojego oponenta. To nie ode mnie, ale od niego zależy, czy zechce przyjąć milczeniem pojawienie się mojej książki, czy też, jak to zapowiedział, da mi odpowiedź.

Mnie oczywiście wolno będzie na jego odpowiedź dać jeszcze odpowiedź, o ile to uznam po pojawieniu się jego książki za wskazane i potrzebne. Powiem nawet szczerze Waszej Eminencji, że ja z góry już się przygotowałem na to, że O. Siwek da mi odpowiedź i to domyślam się jaką. Albowiem zapowiedział mi walkę aż do końca $\mathrm{w}$ jednym $\mathrm{z}$ listów swoich pisanych do mnie jeszcze wówczas, gdy moje artykuły w „Ateneum” się nie ukazały. Dlatego na wszelki wypadek na tę odpowiedź O. Siwka pozostawiłem w odwodzie pewne dokumenty, których dotąd nie opublikowałem; sądzę jednak, że będą one dla O. Siwka prawdziwie druzgocące.

Ale to do rzeczy nie należy; ja tylko stwierdzam wobec wyrażonego przez Waszą Eminencję życzenia, ażebym podał jakiś wniosek załatwienia kompromisowego tej sprawy, że ja żadnego wniosku postawić nie mogę i nie mam prawa. Gra w tym wzgląd nie tylko zasadniczy, ale przyznam się, także i osobisty. Albowiem ja nie mam do czynienia z samym O. Generałem, którego charakter tak wysoko cenię, ale mam do czynienia przede wszystkim z moim oponentem, O. Siwkiem.

1987, Tarnów 1987, s. 365; A. Nowak, Słownik biograficzny kapłanów diecezji tarnowskiej 1786-1985, 4, Tarnów 2004, s. 187-188.

223 Łac.: miastu i światu.

${ }^{224}$ Potoczne określenie Papieskiego Uniwersytetu Gregoriańskiego w Rzymie. 
A mam na to smutne bardzo doświadczenie przekręcania na wspak przez niego najniewinniejszych nawet kroków z mej strony, które się łączą z Konnersreuth.

Muszę dla przykładu podać Waszej Eminencji kilka próbek tych metamorfoz, jakie O. Siwek uczynił choćby już tylko w przelotnym zetknięciu się ze mną, a nawet $\mathrm{z}$ listami moimi pisanymi do $\mathrm{O}$. Generała.

A więc na przykład, kiedy byłem w Krakowie i po zaproszeniu go na obiad przez ks. Metropolitę 225 podczas mojej bytności, odwiedziłem go w domu na Wesołej $^{226} \mathrm{i}$ poruszyłem $\mathrm{w}$ rozmowie $\mathrm{z}$ nim kwestie $\mathrm{z}$ psychologii nowoczesnej, to wystarczyła ta półgodzinna rozmowa z nim, ażeby na prawo i lewo rozgłaszał, że pobierałem u niego lekcje psychologii. To jest naiwne i śmieszne z pewnością, ale dla jego metod znamienne. Ja czytałem list jednego z jego adherentów, w którym ten za nim to zdanie powtarza; następnie pytałem go wówczas w Krakowie, co też on myśli o Konnersreuth; mając pisać książkę zwykłem rozważać z ludźmi nauki te problemy. Prosiłem go bez ogródek, ażeby mi wypowiedział zdanie, co sądzi o moich odczytach w Krakowie. On mnie nieszczerze chwalił, ale zdania swojego o Konnersreuth w niczym mi nie chciał wyjawić i ukrył się przede mną nawet z planem swoim napisania książki o Konnersreuth, a mimo to rzucał potem cień na mój charakter w kwestiach dotyczących jego książki. To rozgłaszali OO. Jezuici w różnych stronach krzywdząc mnie w ten sposób niesłychanie.

Albo na przykład pisałem list do O. Generała w kwestii zakończenia moich artykułów w „Ateneum”, które ze względu na jego osobę i jego życzenie myślałem inaczej ułożyć, to jest w formie oświadczenia na samym końcu jeszcze raz powtórzonego w kwestii stosunku O. Siwka do racjonalizmu. Niestety, wysłany mój tekst nie został wydrukowany. Otóż O. Siwek powołując się na mój list do O. Generała pisze do jednej zupełnie obcej mu redakcji, że ja w liście do O. Generała sam się przyznałem, że wobec niego posunąłem się za daleko etc.; albo na przykład czego też on nie uczynił z cytatem mojego listu, w którym mu odmawiałem zgody na jego prośbę, by mu dać zezwolenie na ogłoszenie mnie odpowiedzi i poddałem tę sprawę decyzji O. Generała. Jak to zaznaczyłem w mej przedmowie, O. Siwek przez wyjęcie z tekstu jednego zdania powołuje się na moje słowa w swej książce, jako na zachętę z mej strony, by napisał odpowiedź. Kto jest w stanie coś podobnego zrobić $\mathrm{z}$ listu prywatnego, to czegóż on nie zrobi $\mathrm{z}$ dokumentu innego?

Przyzna mi tedy Wasza Eminencja, że pomijając względy zasadnicze miałbym głębokie przekonanie, że O. Siwek wszelki krok z mej strony pochwyciłby jako pożądaną dla siebie okazję, ażeby go przekręcić, ażeby wytłumaczyć jako kapitulację moją i cofnięcie się na całej linii przed nim i bodaj czy by nie przydał

225 Adama Stefana Sapiehę.

${ }^{226}$ Chodzi o dom jezuitów przy ulicy Mikołaja Kopernika, usytuowany na terenie ówczesnej dzielnicy Wesoła. 
jeszcze, że to się stało na nakaz Rzymu! Bo przecie teraz świeżo zmyślił wobec ks. Biskupa Przeździeckiego legendę, że S[anctum] Officium chce wkroczyć w tę sprawę dowiedziawszy się, że mam moją książkę tłumaczyć na język niemiecki.

Są to z pewnością względy dodatkowe, ale Wasza Eminencja uzna, że one także grają dużą rolę w tej rozprawie i w tym właśnie wypadku, gdzie O. Siwek ma wszelkie prawo wypowiedzieć się do końca i gdzie projekt z mej strony zepchnięcia tej dyskusji z publicznej rozprawy miałby istotne wszelkie pozory, a nawet cechy tak się nadające do wyzyskania ze strony O. Siwka.

Otóż przedstawiam Waszej Eminencji tę prawdziwą trudność, jaka się nasuwa w rozwiązaniu sporu na wszelkiej innej drodze, jak na tej, na którą spór został zepchnięty i to wciągnięty z niesłychaną reklamą i rozgłosem; jakkolwiek więc w głębi mego serca niesłychanie mi będzie bolesnym iść w tej sprawie do końca, tak ze względu na O. Generała jak i OO. Jezuitów, jakkolwiek rad bym poświęcić naturalną chęć, by rzucić na szalę sporu ostateczne rozstrzygające słowo, to jednak ja z mej strony nie mogę niczego przedsięwziąć, co by spór skierowywało na inne tory, jak na tory ściśle naukowej dyskusji.

Druga trudność w załatwieniu kwestii rodzi się stąd, że do dyskusji naukowej przymieszała się kwestia moralna, a mianowicie kwestia ataków O. Siwka na mnie. Albowiem w książce swej nie tylko czyni on aluzję przejrzystą do mego charakteru dając do poznania, iż co innego piszę, a co innego myślę, ale czyni mi publiczny zarzut, iż ja jako katolicki biskup głoszę błędną naukę contra doctrinam chcristianam twierdząc, że proroctwa są nie oddzielne od ekstazy. Ponadto O. Siwek na jednym publicznym wykładzie w instytucie uniwersyteckim w Rzymie wobec młodzieży różnych narodowości, publicznie po imieniu mnie zaatakował i obrzucił mię po prostu kpinami. Ja mam na to dowód w sprawozdaniu pisemnym jego bezpośrednich słuchaczy, a także w sprawozdaniu pośrednim zakonnic z Rzymu, którym alumni innych narodowości najdokładniej szczegóły tego ataku O. Siwka opowiadali. Wasza Eminencja zrozumie dobrze, że podobny publiczny występ domaga się zadośćuczynienia i to nie tylko dla mojej osoby, ale poniekąd dla prestiżu polskiego Episkopatu, którego jestem członkiem.

Sprawa więc moja z O. Siwkiem nie jest tylko sprawą problemu naukowego, ale z nią się łączy też i problem moralny. Pomijam inne występy O. Siwka jako już mniej znaczące wobec tych, które wymieniłem.

Dziś występuje jeszcze inna trudność w rozwiązaniu prywatnym tej sprawy. Mianowicie, iż pod wpływem OO. Jezuitów i Gregorianum w Rzymie - tak mi przynajmniej doniesiono - broszura O. Siwka skierowana przeciwko mnie rozchodzi się w Niemczech. Miałem na to sam dowody, bo mi o tym mówili, już też pisali księża z zagranicy i świeccy uczeni; nie wiem w jaki sposób to się dzieje, ale nie ma kwestii, że propaganda $\mathrm{z}$ tą broszurą mimo, że nie została wydrukowana, przy pomocy niemieckich jezuitów trwa na całej linii. Ujawniła się ta propaganda najsilniej w tym, że niemiecki związek protestancki i niemiecki ra- 
cjonalizm użył książki O. Siwka dla uderzenia tak w zjawiska Konnersreuth, jak we mnie, jak w bawarskich XX. Biskupów, którzy właśnie śledzeniem tej sprawy się zajmują. Ponieważ tyle czasu i tyle pracy włożyłem w problem Konnersreuth, nie mogę być obojętny na taki objaw, w który racjonalizm wciąga już nie samego O. Siwka, ale całe Gregorianum. Jak w tej sprawie postąpię, tego ja sam dziś jeszcze nie wiem; przedtem nim to nastąpiło, odmówiłem po dwakroć prośbie ze strony wydawnictw niemieckich do thumaczenia mej książki na język niemiecki. Ale dziś sytuacja zasadniczo się zmieniła i ja jeszcze nie wiem, jak w tej sprawie postąpię i postąpić będę musiał. Gdyby więc ewentualnie przyjść miało do jakiejś rozprawy naukowej w Niemczech, na przykład przez przetłumaczenie mej książki na język niemiecki lub coś podobnego, lękałbym się, by mi w tej kwestii nie pętało rąk jakiekolwiek załatwienie kompromisowe czy inne tego problemu tutaj w kraju. Jest to dla mnie szczególniej z tego względu ważne, że mam na ukończeniu duże dzieło o Konnersreuth, w którym wprawdzie O. Siwkiem się nie zajmuję, ale bądź co bądź dzieło to przede wszystkim dla Niemiec przeznaczam ${ }^{227}$. Nie mogę więc być obojętny na takie uderzenie z tyłu na mnie i na problem, w który tyle już pracy włożyłem.

W końcu przychodzę do bardzo ważnej kwestii poruczonej przez Waszą Eminencję, tj. zarzutu racjonalizmu, jakoby przeze mnie wedle sądu O. Generała „ogólnie postawionego". Otóż ja przeciwko temu twierdzeniu miałbym poważne zastrzeżenia. Pisząc bowiem odprawę O. Siwkowi zdawałem sobie doskonale z tego sprawę, że ogólnie stawiając zarzut podobny O. Siwkowi, mógłbym mu wyrządzić ciężką krzywdę. Z tego powodu bardzo ściśle rozróżniłem w mojej pierwszej jeszcze pracy pomiędzy osobistymi przekonaniami O. Siwka, a jego przewodnią tezą $\mathrm{w}$ książce o Konnersreuth; nie tylko broniłem wiary i pobożności O. Siwka w mej pracy, ale wręcz stwierdziłem, że stoi on na przeciwnym biegunie racjonalizmu i że go zwalcza uznając pierwiastek nadprzyrodzony, któremu racjonalizm zaprzecza. Stwierdziłem tylko fakt, iż O. Siwek w zjawiskach mistycznych, na przykład w zjawiskach ekstazy, którą on sam w swej drugiej książce słusznie nazywa istotnym objawem stygmatyzacji, oparł swój sąd o tych zjawiskach jedynie i wyłącznie o analogie z psychopatią, a pominął zupełnie kryteria mistyczne. To nie jest żadna moja opinia, to jest fakt, o którym się każdy przekonać musi.

Na dowód, że takie analizowanie rzeczy schodzi się z tezą racjonalizmu przytaczam nie moje słowa, ale własne słowa O. Siwka. Na stronnicy 36-tej drugiej swej pracy o literaturze religijnej „areligijnych” pisarzy, pisze on: „Wychodząc z założeń materialistycznych i oparci o metodę pozytywistyczną, posługującą się w badaniach kryteriami wyłącznie pozytywnymi, usiłowali oni sprowadzić całą mistykę do pewnych zjawisk doświadczalnych, podległych obserwacji zewnętrz-

227 J. Teodorowicz, Konnersreuth im Lichte der Mystik und Psychologie, Salzburg 1936. 
nej, do pewnych funkcji organicznych. Na szczęście pogląd ten na mistykę wraz z materializmem i pozytywizmem, które były jego podporą, już się przeżył"228.

$\mathrm{Z}$ tego tekstu O. Siwka wynika, że rozpatrywanie zjawisk mistycznych tylko jedynie pod kątem analogi psychopatycznych, a więc metod stosowanych do zjawisk doświadczalnych, jest charakterystycznym znamieniem racjonalizmu i to racjonalizmu przestarzałego.

Oczywiście i ja tak samo stwierdzam w mej książce, iż w metodach naukowych wyrzucenie kryteriów mistycznych przy analizie zjawisk mistycznych jest upodobnieniem do metod racjonalistycznych.

To był mój punkt wyjścia w mej pracy, to był główny powód, dla którego się jej podjąłem. Właśnie dlatego, że podobna infiltracja jest nieuświadomiona u autora, tym bardziej należy zwrócić na ten prąd baczną uwagę; im zaś wyższy jest autorytet takiego autora dzięki jego pozycji naukowej, tym może być niebezpieczniejszy wpływ podobnej infiltracji. Tu nie chodzi o to, czy szkodzi ona prestiżowi naukowemu czy nie, to jest rzecz drugorzędna; tu idzie o to, czy zarzut został stwierdzony tekstami czy też nie.

Sądzę, że jest to zupełnie w duchu Kościoła tak na ten problem patrzeć. Dla przykładu podaję tu znaną i rozgłośną sprawę z książką z dziedziny katolickiej egzegezy wydaną przed paru laty: Vigouroux-Bacuez (w wydaniu Brassac-Ducher $)^{229}$. Autor wychodził ze stanowiska nadprzyrodzonego w tej książce, uznawał porządek nadprzyrodzony jak cudów etc., a jednak z powodów nieuświadomionej u niego infiltracji prądów racjonalistycznych książka ta dostała się na indeks, a nadto jeszcze ówczesny sekretarz Stanu Gasparri wydał list ostrzegający przed kierunkami ulegającymi metodom racjonalistycznym.

Jeżeli by się komuś po tym wszystkim jeszcze wydawało, że ja przesadzam i wietrzę racjonalizm tam gdzie go nie ma, to powołuję się na zdanie jednego autora znanych dzieł, którego nazwisko Waszej Eminencji przy sposobności widzenia się mogę ujawnić. Otóż ten jezuita znał książkę O. Siwka i powiedział znajomym mi kapłanom przebywającym zagranicą, że jest to książka napisana w duchu racjonalistycznym i że on się tylko dziwi, jak mógł konsystorz krakowski na taką książkę dać swoją aprobatę.

Nie cytuję już zdań bardzo poważnych uczonych polskich, z których jeden znany pisarz zakonny, nie dominikanin, mówił mi, jaki wstręt wywołało samo czytanie książki O. Siwka w refektarzu właśnie z powodu nasiąknięcia duchem racjonalizmu, który nawet krytyczni badacze w tej książce wyczuwali.

228 P. Siwek, Metody badań zjawisk nadprzyrodzonych, s. 36.

229 F. Vigouroux, G. Bacuez, A. Brassac, Manuel biblique ou Cours d'Écriture Sainte, à l'usage des Séminaires. Ancien Testament, 1, Les Livres historiques, à l'exception du Pentateuque, Paris 1917, 2, Les Livres didactiques et les Livres prophétiques, Paris 1920. Książka wpisana została na Indeks Ksiąg Zakazanych 12 grudnia 1923 roku. Index librorum prohibitorum Leonis XIII summi pontificis auctoritate recognitus SSMI D. N. Pii PP. XI iussu editus, Romae 1925, s. 333-334. 
Muszę tu tylko jeszcze podnieść, że byłem w mym sądzie niesłychanie ostrożnym, bo wyraźnie zaznaczyłem, że gdyby O. Siwek nie rościł sobie pretensji rozwiązywania problemu Konnersreuth ze stanowiska religii, a ograniczył się li tylko do analogii tych zjawisk z psychopatią, to wówczas mógł i miał prawo pominąc kryteria mistyczne i byłby dzięki nagromadzonemu materiałowi przysłużył się rozwiązaniu problemu Konnersreuth. Na osobnej karcie dołączam Waszej Eminencji dosłowne cytaty, odnoszące się do tych twierdzeń, a wyjęte z moich rozpraw. (Tego już po tak długim liście nie czynię) ${ }^{230}$.

Wszystko to co napisałem raz jeszcze przedstawiam jako trudności, wychodząc przy tym z założenia podanego wyżej, że ode mnie nie może wyjść żaden projekt w tej kwestii, którą całą składam dzisiaj w ręce Waszej Eminencji, łącząc dla Osoby Waszej Eminencji wyrazy mej najgłębszej i najoddańszej czci ${ }^{231}$

Lwów, dnia 31 stycznia $1934^{232}$

41.

FKiDOP, t. 130, sygn. 1629/185 [4], s. 48-49, arcybp J. Teodorowicz do kard. A. Hlonda ${ }^{233}$.

Wasza Eminencjo!

W liście, który wysłałem Waszej Eminencji był jeden szczegół nieścisły, który, prosiłbym z listu wykreślić. Dotyczy on mianowicie rzekomej rozmowy ks. Biskupa Przeździeckiego z O. Siwkiem.

Przy tej sposobności proszę Waszą Eminencję o wytłumaczenie mnie, iż na zjazd w lutym nie będę mógł przybyć do Warszawy ze względu na moje zdrowie. Jest mi wprawdzie lepiej, nawet względnie dobrze, ale lekarze obawiają się każdego większego wysiłku, gdyż jeszcze nie ma dostatecznego poprawienia stanu mego zdrowia.

Przy tej sposobności przychodzi mi na myśl wspomnienie z Krynicy sprzed roku właśnie, o którym mówiłem Waszej Eminencji. Mianowicie rok temu, gdy był formalny zjazd XX. Biskupów w Krynicy, przywiozła K[atolicka] A[gencja] P[rasowa] w osobie ks. Kaczyńskiego wiadomość z Rzymu, że ksiądz Bross dostał prałaturę. Ani się nawet zająknął gdy to mówił, stwierdził to jako pewnik nie ulegający wątpliwości tak, żeśmy wszyscy zaczęli ks. Brossowi gratulować i tylko on jeden przeciwko przyjęciu gratulacji protestował.

Nie śmiem oczywiście podsuwać Waszej Eminencji żadnych wniosków, ale jednak sądzę, że jeżeli nie ma wejść w przysłowie okrzyk Moraczewskiego ${ }^{234}$ :

${ }^{230}$ Zdanie dopisane odręcznie czarnym atramentem.

231 Brak podpisu.

232 Data dopisana odręcznie czarnym atramentem.

233 Mszps pisany na 2 stronach cienkiego papieru formatu A4.

234 Prawdopodobnie chodzi o Jędrzeja Moraczewskiego (1870-1944), socjalistę, przed pierwszą wojną światową posła do austriackiej Rady Państwa z ramienia Polskiej Partii 
„Kłamie jak K[atolicka] A[gencja] P[rasowa]!”, to w takim razie coś by jednak należało $\mathrm{z}$ tym fantem uczynić.

Łączę dla Waszej Eminencji wyrazy najoddańsze mej czci najgłębszej, sługa w Chrystusie ${ }^{235}$

Lwów, dnia 7 lutego $1934^{236}$

42.

FKiDOP, t. 130, b. sygn., s. 52-53, arcybp J. Teodorowicz do kard. A. Hlonda ${ }^{237}$.

\section{Wasza Eminencjo!}

Jeszcze raz wracam do kwestii poruszonej w liście Waszej Eminencji a to pod wpływem listu, jaki otrzymuję od ks. Arcybiskupa Sapiehy. Donosi mi on, że OO. Jezuici pod pseudonimem wznawiają kwestię O. Siwka i jego obrony w Czasie ${ }^{238}$; pisze mi, że napisał do nich ostry list w tej sprawie.

Otóż nie chodzi mi zupełnie o to, iż oni starają się O. Siwka obronić; ale mam w tym jednak potwierdzenie na to, co Waszej Eminencji pisałem. Wysuwałem mianowicie jako trudność w załatwieniu sporu naukowego w drodze polubownej, [fakt], iż ja się będę czuł przez to związany, kiedy równocześnie OO. Jezuici myślałem pisząc list do Waszej Eminencji tylko o zagranicy - będą pod różnymi pseudonimami czy to w dalszym ciągu atakować, czy w ogóle spór rozwijać. Nie przypuszczałem, iż tak rychło właśnie tutaj ta kwestia zajdzie.

Nie chcę w niczym przesądzać stanowiska, jakie Wasza Eminencja zajmie w całej tej sprawie zapewne po porozumieniu się z O. Generałem, ale przytaczam tylko ten szczegół na potwierdzenie tego, co już pisałem.

Łączę przy tej sposobności dla Waszej Eminencji wyrazy najgłębszej czci, zawsze oddany ${ }^{239}$

Lwów, dnia 9 lutego 1934

Socjalno-Demokratycznej Galicji i Śląska Cieszyńskiego (1907-1918), po wojnie posła i wicemarszałka sejmu (1919-1927), ministra robót publicznych (1926-1929), potem prezesa Centralnego Wydziału Zawodowego Związku Związków Zawodowych (1931-1939). J. Gołębiowski, Moraczewski Jędrzej Edward, w: Kto byt kim, s. 56.

235 Brak podpisu.

236 Pod datą zamieszczono: „Ks. Prymas Hlond”.

${ }^{237}$ Mszps pisany na 2 stronach cienkiego papieru formatu A4. U góry na środku kartki dopisano odręcznie: „nie poszło”. Po lewej stronie odręczny dopisek archiwisty: „Hlond”.

238 „Czas” - dziennik polityczno-informacyjny wydawany w latach 1848-1934 w Krakowie oraz w latach 1935-1939 w Warszawie, związany z nurtem konserwatywnym, po 1926 roku należał do wydawnictw prorządowych. J. Łojek, J. Myśliński, W. Władyka, Dzieje prasy polskiej, s. 41, 99.

239 Brak podpisu. 
43.

FKiDOP, t. 130, b. sygn., s. 54-55, arcybp J. Teodorowicz do kard. A. Hlonda ${ }^{240}$.

Pozwolę sobie jeszcze raz wrócić do sprawy O. Siwka. Właśnie pisał mi arcybiskup Sapieha, że się pojawił w „Czasie” artykuł241, który pochodzi od Jezuitów w obronie O. Siwka. X. biskup krakowski napisał do Jezuitów ostry list i trafił w sedno rzeczy; albowiem wcale nie próbują się bronić, jakoby artykuł ten od nich nie pochodził. Ja artykułu tego w „Czasie” nie czytałem, ale przypuszczam, że to będzie artykuł podobny do tego, który się ukazał w „Dzienniku Poznańskim”242.

Otóż pracując przez rok nad książką przeciw O. Siwkowi poznałem od razu jego styl, jego sposób argumentacji, słowem poznaję, że autorem tego artykułu nie jest kto inny jak O. Siwek. Pomijam zupełnie treść artykułu i wprost niebywałe metody ze stanowiska nawet moralnej reklamowej apologii O. Siwka. Jakkolwiek piszę o tym Waszej Eminencji, to czynię to dla innych względów; mianowicie mam w tym potwierdzenie tego, co Waszej Eminencji pisałem. OO. Jezuici zdaje się zechcą jakichś oświadczeń ode mnie, dając mi wzajemnie przyrzeczenie, że O. Siwek nie da mi odpowiedzi; już nawet podobno zabroniono im wydania odpowiedzi przeciw mnie. Ale za to będzie on atakował mnie drogą po prostu zwykłego kłamstwa w przekręcaniu stanu rzeczy na wszystkie strony. Tak się już dzieje zagranicą, skąd mi przysłano artykuł O. Reismanna ${ }^{243}$ widocznie pisany pod wpływem O. Siwka, bo mniej więcej argumentacja jest ta sama.

Kiedy więc ja byłbym związany, to równocześnie pod pozorem zakończenia sporu będę atakowany ze strony Jezuitów i to nie w sposób naukowy, ale jak to jest w tym wypadku, przez kłamstwo w przekręcaniu faktów. Dobrze by było, by Generał wiedział o tym, że chyba w ten sposób na drogę pogodzenia sprawy się nie skierowuje. Ja oczywiście, jeżeli Ojcowie dalej iść będą tą metodą prostego kłamstwa, będę zmuszony wystąpić publicznie w sposób, na jaki ich metody zasługują.

Łączę dla Waszej Eminencji wyrazy mej czci najgłębszej ${ }^{244}$

Lwów, dnia 14 lutego $1934^{245}$

${ }^{240}$ Mszps pisany na 2 stronach cienkiego papieru formatu A4. U góry karty dopisano czarnym atramentem: „14/II [1]934”.

241 J. N., Konnersreuth, „Czas”, 1934, 36, s. 4.

242 „Dziennik Poznański” - informacyjno-publicystyczna gazeta liberalna o programie narodowym założona przez Hipolita Cegielskiego w Poznaniu, ukazywała się w latach 18591939. J. Łojek, J. Myśliński, W. Władyka, Dzieje prasy polskiej, s. 41, 60-61.

${ }^{243}$ Prawdopodobnie chodzi tu o dra Rolfa Reissmanna, luteranina, który kilkakrotnie zabierał głos w sprawie Teresy Neumann, między innymi w artykule Das Mirakle von Konnersreuth, „Der Tag”, 6 września 1927. Tytułu i miejsca wspomnianej w liście kolejnej publikacji Reissmanna nie udało się ustalić.

244 Brak podpisu.

245 Pod datą dopisano: „Ks. Prymas Hlond-Poznań”. 


\section{4.}

FKiDOP, t. 130, sygn. 1602/185 [4], s. 57, arcybp J. Teodorowicz do kard. A. Hlonda ${ }^{246}$.

\section{Wasza Eminencjo!}

Przede wszystkim bardzo gorąco dziękuję Waszej Eminencji za wspaniały list pasterski ${ }^{247}$. Ujmuje on wszystkie nasze bolączki i aktualne problemy na bardzo szerokiej płaszczyźnie, a również i kładzie kropkę nad ,i” śmiało i odważnie. Jest to naprawdę list wspaniały, piękny, silny i tak aktualny. Ma on jeszcze tę wielką wartość, że w opinii całej zjednoczył Episkopat w jeden obóz.

Przy tej sposobności posyłam Waszej Eminencji kopię listu O. Generała Ledóchowskiego do mnie i moją odpowiedź na ten list ${ }^{248}$.

X. Metropolita Szeptycki ${ }^{249}$ mówił mi, iż był u niego X. Biskup z Jugosławii (nie umiem ściśle podać brzmienia jego nazwiska Niedbalow? ${ }^{250}$ ), który powrócił $\mathrm{z}$ audiencji od Ojca św. I Ojciec św. powiedział mu: będą wkrótce prześladowania Kościoła tak w Jugosławii, jak i w Polsce.

Łączę dla Waszej Eminencji najoddańsze wyrazy czci najgłębszej ${ }^{251}$

Lwów, dnia 26 lutego $1934^{252}$

45.

FKiDOP, t. 130, sygn. 1593/184 [7], s. 82-88, arcybp J. Teodorowicz do kard. A. Hlonda ${ }^{253}$.

Wasza Eminencjo!

Dziękuję za list właśnie otrzymany od Waszej Eminencji i przesyłam dołączniki do sprawy O. Siwka.

${ }^{246}$ Mszps pisany na 1 stronie papieru formatu A4.

247 O ducha chrześcijańskiego w Polsce. List pasterski Episkopatu Polski, Płock [1934].

248 Załączniki do listu nie zachowały się.

249 Andrzej Szeptycki (1865-1944) - po zmianie obrządku z łacińskiego na greckokatolicki rozpoczął w 1888 roku nowicjat w zakonie bazylianów w Dobromilu, święcenia kapłańskie przyjął w 1892 roku w Przemyślu, ordynariusz greckokatolickiej diecezji stanisławowskiej (1899-1900), arcybiskup metropolita lwowski tegoż obrządku (1900-1944). Metropolita Andrzej Szeptycki. Studia i materiały, red. A. A. Zięba, Kraków 1994.

${ }^{250}$ Dionizije Njaradi (1874-1940) - greckokatolicki biskup Križevci od 1940 roku, od 1922 do 1927 roku był ponadto administratorem apostolskim diecezji preszowskiej, a w latach 1938-1939 - diecezji mukaczewskiej.

${ }^{251}$ Brak podpisu.

252 Pod datą dopisano: „Kardynał Prymas Hlond”.

${ }^{253}$ Mszps pisany na 7 stronach papieru formatu A4. Na pierwszej stronie u góry dopisano czarnym atramentem: „J[ego] E[minencja] X. Prymas 13/3 [1]934”. 
Zwracam uwagę na dwa listy ks. biskupa Przeździeckiego, w których jest tendencja, ażeby mnie odwieść od thumaczenia na język niemiecki mojej książki, z tajemniczą jakąś pogróżką aż [z] S[anctum] Officium. Źródła tej pogróżki należało szukać tam, gdzie ją wskazał ks. biskup, tj. na Piazza Borgo di S[anto] Spirito $^{254}$. Otóż jest to niesłychanie ciekawa ilustracja metod i postępowania tej właśnie grożącej strony, iż właśnie został dokonany przekład broszury O. Siwka przeciwko mnie na język francuski ${ }^{255}$. Jest tu we Lwowie na trzeciej probacji jezuita, doskonale poinformowany o tych kwestiach, który wobec znajomego mi kapłana mówił właśnie o tym przekładzie francuskim stanowiącym wedle niego dowód, jakie poważne naukowe znaczenie ma ta praca O. Siwka. Ja oczywiście biorę ten przekład z innej zupełnie strony. Chodziło w tym przekładzie niezawodnie o sprawę salwowania prestiżu profesora Gregorianum wobec mojej ostatniej książki, a następnie chodziło i o to, ażeby tą drugą książką przesłonić braki książki pierwszej. W każdym razie rzuca to światło na całą sprawę.

$\mathrm{Z}$ jednej strony jest tu dążenie do zamknięcia mi ust zagranicą, kiedy $\mathrm{z}$ drugiej strony równocześnie przypuszcza się atak na mnie i to pośród pertraktacji o pośrednictwo Waszej Eminencji. Ja nie miałem zupełnie zamiaru tłumaczenia mojego dzieła na język niemiecki; odmówiłem nawet parokrotnie ofertom, które do mnie przyszły z Niemiec, ale czy w ten sposób zaatakowany nie będę w końcu zmuszony do odpowiedzi przez przekład mojej książki, to nad tym poważnie zastanowić się muszę. W każdym razie dobrze by było, aby Generał wiedział o tym, że przecież kroki jakie on czyni mają swoje konsekwencje i muszą je mieć. Wypieranie się wszelkie jest wobec dokumentów, jakie Generałowi przedłożyłem zupełnie bezcelowe. Także ten jezuita z probacji trzeciego roku przybywający we Lwowie tłumaczył znajomemu mi kapłanowi, że o każdym kroku O. Siwka wie Generał i każdy jego krok jest przez Generała aprobowany.

Dodaję tu jeszcze Waszej Eminencji dwa ustępy z dwu listów O. Siwka, przesyłanych do mnie jeszcze wówczas, zanim się pojawiły moje artykuły w ,Ateneum". Otóż w dwóch tych listach jest czarno na białym, iż O. Siwek mistyki wcale nie używał w rozpoznaniu i w sądach o zjawiskach mistycznych. Co więcej! Uważa on użycie mistyki za przesądzenie zjawisk mistycznych, czyli uważa, że użycie mistyki jest dla badania naukowego nie tylko czymś zbędnym, ale nawet wprost szkodliwym. Albowiem przesądza o problemie z góry, kiedy tymczasem badanie naukowe powinno zająć stanowisko wyczekujące.

Otóż te właśnie słowa O. Siwka są dla niego zabójcze. Wobec tego, że on się posługuje tekstem mojego listu w swej pracy i to po dwakroć, miałem wszelkie

254 Siedziba Kurii Generalnej Towarzystwa Jezusowego w Rzymie.

${ }^{255}$ Broszura nie ukazała się wtedy w wersji drukowanej, natomiast po francusku o. Siwek jeszcze dwukrotnie potem publikował na ten temat: Les guérisons de Thérèse Neumann a la lumière de la médicine, „Bolletin de la Academia Nacional de Medicina” (1941) i Les stigmates, „Anais da Academia Brasileira de Ciências” (1944). 
prawo w mojej książce opublikować te jego oświadczenia, które od razu kładą kres całemu sporowi i przedstawiają właściwe oblicze O. Siwka, który stoi na stanowisku zupełnego racjonalizmu w swojej książce. Tego nie uczyniłem; ale proszę Waszą Eminencję jeszcze dzisiaj zachować o tych szczegółach wobec Generała dyskrecję, bo może przyjść czas, gdzie mi te szczegóły będą potrzebne, a nie chciałbym, aby jezuici byli o nich uprzedzeni.

Co do tłumaczenia francuskiego, to nie wiem dokładnie, czy ono się już ukazało w druku i jeżeli jest drukowane, to czy jest opublikowane jako manuskrypt, czy też jako książka. Jeszcze słówko dodam co do przebiegu obecnych krytyk i dyskusji publicznych.

Ks[iądz] Metropolita Sapieha po porozumieniu się ze mną, gdy się książka moja ukazała, zwrócił się do jezuitów z tym, że ja więcej tej kwestii nie chcę poruszać, ale pod warunkiem, że oni będą milczeć; wezwał ich dlatego, aby nic więcej w tej kwestii nie pisali. Tymczasem jakby w odpowiedzi na to pojawia się w I[lustrowanym] K[urierze] C[odziennym] artykuł uderzający na mnie jak na jakiego herezjarchę, zarzucający mi wprost fideizm. Po stylu, po układzie argumentów, po nacisku na swoje własne ,ja”, poznałem od razu autora. Był nim nie kto inny tylko O. Siwek. Przez mojego kanonika ks. Isakowicza ${ }^{256}$ zostało posłane do tej gazety sprostowanie zupełnie rzeczowe, które sam metropolita poprawił tak, ażeby nie było najlżejszego nawet tonu osobistego. Po tym sprostowaniu czysto rzeczowym pokazuje się w tym samym piśmie artykulik znowu uderzający choć pośrednio na mnie i anonsujący jako rewelację nową odpowiedź, jaka się ma ukazać, O. Siwka. Ci naiwni, którzy wierzą jeszcze w zjawiska Konnersreuth, dopiero się doczekają nowych niespodzianek!

Ten artykuł nie był wprawdzie pisany bezpośrednio przez O. Siwka, ale był przez niego inspirowany; ukazał się bowiem pod pseudonimem „Miel”, a to jest pseudonim ks. Weryńskiego, który jak to powszechnie wiadomo, jest agentem O. Siwka.

Na tym jednak jezuitom nie było dość. Pojawiają się znowu dwa artykuły o Konnersreuth, które znowu pisze nie kto inny, tylko O. Siwek. Ks. biskup krakowski natychmiast napisał do jezuitów krakowskich list bardzo silny za te artykuły. Milczenie ich było najlepszą odpowiedzią, że trafił pod właściwy adres. Wszystkie te artykuły tak pisane do „I[lustrowanego] K[uriera] C[odziennego]”, jak do „Czasu” i „Dziennika Poznańskiego” opierają się stale na sfałszowaniu

${ }^{256}$ Leon Isakowicz (1897-1944) - kapłan archidiecezji lwowskiej obrządku ormiańskokatolickiego, święcenia kapłańskie otrzymał w 1919 roku, asystent przy Katedrze Historii Sztuki Kościelnej na Wydziale Teologicznym Uniwersytetu Jana Kazimierza we Lwowie (1920-1922), katecheta w gimnazjach żeńskich we Lwowie, kanonik kapituły ormiańskiej (od 1930), administrator, a następnie proboszcz parafii ormiańskiej w Stanisławowie (1936-1944). T. Zaleski, Stownik biograficzny duchownych ormiańskokatolickich oraz duchownych rzymskokatolickich pochodzenia ormiańskiego w Polsce w latach 1750-2000, Kraków 2001, s. 52. 
mojej przewodniej tezy przez O. Siwka, jakobym ja atakował jego ostrożność naukową duchem Kościoła i wiedzy podyktowaną, a usiłował tylko wszczepić ślepą, naiwną wiarę w nadprzyrodzoność zjawisk w Konnersreuth. W tym właśnie tkwi fałsz i zła wola O. Siwka, któremu akompaniują jego koledzy zakonni. Prawda, że nie wszyscy; są tacy, którzy uważają go za pyszałka dążącego do rozgłosu przez ambicję, a wśród nich jest sam prowincjał ${ }^{257}$, który chciał nawet, aby do mnie doszło, jakie ma o nim przekonanie. Proszę oczywiście Waszą Eminencję o dyskrecję w tej kwestii.

Otóż wobec tego, tak jak ewentualne kroki moje zagranicą wywołują właśnie OO. Jezuici swoim całym postępowaniem, podobnie dzieje się teraz i w kraju. Mój kanonik ks. Bogdanowicz chciał pisać recenzję mojej książki zaraz po jej ukazaniu się, ja go jednak wstrzymałem właśnie dlatego, ażeby nie dolewać oliwy do ognia. Na recenzje, które się ukazały, bardzo zresztą poważne, znakomitego teologa O. Fica ${ }^{258}$ i kanonika poznańskiego ks. Steuera ${ }^{259}$ nie wywierałem żadnego wpływu i dowiedziałem się o ich recenzjach bardzo spokojnych i rzeczowych dopiero ex $\operatorname{post}^{260}$. Jednym słowem stałem na stanowisku, ażeby tej całej sprawie najmniej nadawać rozgłosu. Ale kiedy się ukazały artykuły wprost czelne w „Czasie” i „Dzienniku Poznańskim”, wtedy już pozwoliłem ks. Bogdanowiczowi na odpowiedź261. Nawet dołączam ją ${ }^{262} W$ [aszej] Eminencji nie tyle ze względu na treść, ile ze względu na list ks. b[is]k[u]p[a] Buchbergera ${ }^{263}$,

257 Był nim wówczas o. Włodzimierz Konopka SJ.

258 Atanazy Fic (1901-1943) - dominikanin, święcenia kapłańskie otrzymał w 1925 roku, doktor teologii Uniwersytetu Jana Kazimierza we Lwowie (1929), habilitowany na Wydziale Teologicznym UJ (1933), był rektorem Studium Filozoficzno-Teologicznego Dominikanów we Lwowie (1930-1936), wykładał archeologię biblijną i języki starożytne na uniwersytetach w Krakowie (1933-1936) oraz Lwowie (1936-1939). J. Wołczański, Wydział Teologiczny Uniwersytetu Jana Kazimierza we Lwowie 1918-1939, Kraków 2002, s. 205, przyp. 81. Recenzji książki arcybiskupa Teodorowicza autorstwa o. Fica nie udało się odnaleźć, nie ma zatem pewności, czy ukazała się drukiem.

259 Albert Steuer (1874-1967) - kapłan archidiecezji poznańskiej, święcenia kapłańskie otrzymał w 1899 roku, wykładowca Arcybiskupiego Seminarium Duchownego w Poznaniu, kanonik gremialny kapituły metropolitalnej tamże (od 1911). Rocznik archidiecezji gnieźnieńskiej i poznańskiej na 1938 rok, Poznań 1938, s. 144; Rocznik archidiecezji poznańskiej na rok tysiaclecia 1968, Poznań 1968, s. 519.

${ }^{260}$ A. Steuer, P. Siwek, Metody badań zjawisk nadprzyrodzonych. Problem Konnersreuth, Kraków 1933; J. Teodorowicz, Zjawiska mistyczne i ich tlumaczenia (Konnersreuth), Poznań 1933 [recenzja], „AT”, 20, 1934, 33, s. 83-90.

261 A. Bogdanowicz, O logikę w mistyce, „Gazeta Kościelna”, 41, 1934, 8, s. 80-82; 41, 1934, 12, s. 132-134.

262 Załącznik do listu nie zachował się.

${ }^{263}$ Michael Buchberger (1874-1961) - niemiecki duchowny katolicki, święcenia kapłańskie otrzymał w 1900 roku, od 1906 roku profesor prawa kanonicznego na Uniwersytecie Filozoficzno-Teologicznym w Ratyzbonie, biskup pomocniczy archidiecezji Monachium i Fryzyngi (1923-1928), ordynariusz diecezji Ratyzbona (1928-1961); redaktor dziesięcio- 
któremu posłałem w dosłownym tłumaczeniu niemieckim wszystkie ustępy książki O. Siwka, w których się powołuje O. Siwek na świadectwa konsystorza regensburskiego.

A propos jeszcze tego artykułu maleńkie i uboczne uwagi. Ks. Bogdanowicz pomieścił w nim szczegół o doktorze Poray-Madeyskim ${ }^{264}$. Ja nie bardzo wiem, czy dr Poray-Madeyski na którego powołuje się O. Siwek jest właśnie identyczny ze znanym doktorem Poray-Madeyskim, który w Rzymie kręcił się koło jezuitów. Otóż trzeba Waszej Eminencji wiedzieć, że ten doktor szpiegował mnie i ks. biskupa krakowskiego w czasie, kiedy byliśmy w Rzymie za czasów jeszcze mojego poselstwa i ja potem w Warszawie czytałem jego referaty o każdym naszym kroku jakeśmy w Rzymie czynili. Ale to tylko mimochodem piszę, bo sprawa ta do rzeczy nie należy.

Ciekawe jest i naiwne zarazem, iż jezuici tłumaczą się, jakoby O. Siwek nie odpowiadał mi teraz dlatego, aby mię oszczędzić. O tym chyba mógł pomyśleć rok temu wstecz, nadając swe artykuły do naukowego pisma „Ateneum”, a nie publikując je szeroko po świecie przez książkę wobec nieznających sprawy czytelników.

Ale czyżbym ja nie wolał odpowiedzi z otwartą przyłbicą, aniżeli tego rodzaju ataki ukryte, systematycznie a ciągłe? Chcą mię oszczędzić! A przygotowali czy też już wydali francuską książkę, w której na podstawie fikcyjnych cytatów przedstawiają mnie jako nieznającego zasad wiary i błądzącego w kwestii proroctw etc.

Chcą mię oszczędzić! I dlatego szukają pośrednictwa przy takich równoczesnych ${ }^{265}$ atakach i z zewnątrz i z wewnątrz! Chyba trzeba wielkiej naiwności, ażeby liczyć na wiarę w takie słowa. To jest prawdą, że Siwek przygotował i ma odpowiedź, którą zakazano mu drukować, ale z pewnością odpowiedź musiała być w tym stylu, w jakim są pisane jego artykuły do „Czasu” i „Dziennika Poznańskiego", tj. przekręcające moje zasadnicze stanowisko. Tyle o kwestii O. Siwka.

Korzystam z tej sposobności, ażeby poruszyć drugą kwestię, tj. kwestię SS. Niepokalanek, w której mnie Wasza Eminencja o sąd i zdanie zapytywał. Otóż przede wszystkim zaznaczam, że wobec obstania nuncjusza za dalszym urzędowaniem dotychczasowego wizytatora, mimo listu, który posłał nuncjuszowi ks. arcybiskup Twardowski, jest faktem, z którym się liczyć należy. Ten

tomowej encyklopedii Lexikon für Theologie und Kirche (Freiburg im Breisgau 1930-1938). Buchberger Michael, w: DBE, 2, München 1995, s. 181.

264 Bolesław Kazimierz Poraj-Madejski (1865-po 1946) - absolwent medycyny na Uniwersytecie Jagiellońskim, w latach pierwszej wojny światowej naczelny lekarz artylerii austro-węgierskiej, następnie major Wojska Polskiego zatrudniony w II Oddziale Sztabu, na zlecenie Biura Propagandy Zagranicznej prowadził akcję w środowiskach katolickich Bawarii i Włoch zainteresowanych akcją unijną wśród prawosławnych, autor publikacji o Konnersreuth: B. de Poray-Madeyski, Le cas de la visionnaire stigmatisée: Thérèse Neumann de Konnersreuth, Paris 1940.

265 Wyraz dopisany ołówkiem. 
wizytator zresztą sam głosi, że go łączą jakieś stosunki z nuncjuszem, który bezwzględnie go będzie popierał. Jeśli tak jest, to nie wiem, czy dyskusja na temat dalszych losów wizytacji w ogóle może być uważana za aktualną.

Co do mnie, to sprawę postawiłbym w ten sposób. Uważam, iż formalnie wizytacja właściwie jest już dawno skończona. Wszystko co należało do zakresu wizytacji, a więc reguła, określenie ról założycielek, aprobata pism Matki Darowskiej wszystko to już jest dawno załatwione. Formalnie więc nie pozostaje nic więcej do zrobienia. Pamiętam doskonale, jak przed dziesięciu mniej więcej laty, pierwszy wizytator Niepokalanek O. Sobolewski mówił mi, że uważa właściwie dzieło wizytacji za skończone i będzie czynił odpowiednie przedstawienia w Rzymie. Pod wpływem mylnych zresztą pogłosek, jakoby Niepokalanki dążyły same do jego usunięcia, nie wdrożył on kroków o jakich mi mówił, raczej uczynił przeciwnie. Ale w każdym razie te słowa jego doskonale pamiętam.

Przyszedł drugi wizytator Trzemeski, którego nieszczęsną wprost rolę działalności we wnętrzu tego Zgromadzenia przedstawiłem Waszej Eminencji. I on też na końcu uznał jego rolę za skończoną i podał się do dymisji. Ten nowy wizytator po załatwieniu ostatecznych wyborów, a raczej po wprowadzeniu bez wyborów nowego zarządu, literalnie nic więcej nie ma do zrobienia pod względem oczywiście formalnym. I naprawdę on dzisiaj w Zgromadzeniu zupełnie nie rządzi, nawiasem mówiąc stracił też i wszelki prestiż wobec spraw znanych, które się przedarły do wiadomości Zgromadzenia.

A więc o ile by chodziło o załatwienie wizytacji pod względem formalnym, to należałoby sobie tego życzyć, ażeby ten wizytator ostatecznie wizytację zakończył. Każdy wizytator bowiem, który nie zna Zgromadzenia, będzie znowu potrzebował całych lat do zapoznania się z nim i będzie znowu to biedne Zgromadzenie prowadził na drogę nowych eksperymentów. Inaczej się atoli ma rzecz, gdyby się znalazł wizytator, który zna Zgromadzenie i wie czego mu brakuje. Za takiego właśnie człowieka, który by się nadawał na wizytatora - bo dla tej roli wewnętrznej - uważam ks. Brossa. Jak i w czym potrzebuje to Zgromadzenie dziś wewnętrznego i duchowego kierunku i duchowej, i wewnętrznej reformy, na to wskazuje list mój do generalnej przełożonejej ${ }^{266}$, który Waszej Eminencji w kopii przesyłam ${ }^{267}$.

Co do $\mathrm{Iki}^{268}$ to prawdopodobnie tam istotnie pojadę. Już skończyłem właśnie dzieło moje o Konnersreuth w niemieckim języku ${ }^{269}$, a teraz biorę się do życia Chrystusa ${ }^{270}$, które się najlepiej pisze nad Adriatykiem. Może by i Wasza

266 Matki Zenony Ludwiki Dobrowolskiej.

267 Załącznik do listu nie zachował się.

${ }^{268}$ Ika - miejscowość wypoczynkowa nad Adriatykiem.

269 J. Teodorowicz, Konnersreuth im Lichte.

${ }^{270}$ Chodzi o wielotomowe dzieło o życiu Chrystusa. W kolejnych latach ukazały się następujące tomy: Od Jahwy do Mesjasza (Poznań 1936) oraz Herold Chrystusa na tle epoki (Poznań 1937). 
Eminencja pomyślał coś o wypoczynku dla siebie? Mówiono mi bowiem, że nie najlepiej wygląda i jest przemęczony.

Całuję pierścień Waszej Eminencji i łączę wyrazy najgłębszej mojej czci, oddany sługa w Chrystusie ${ }^{271}$

46.

FKiDOP, t. 140, sygn. 960/420(8) [7], s. 9-10, kard.A. Hlond do arcybpa J. Teodorowicza ${ }^{272}$.

Ekscelencjo!

Poznań, dnia 9 maja 1934

W poczuciu winy, żem tak długo zwlekał z odpowiedzią na przesłane mi do Rzymu pisma, przede wszystkim bardzo pokornie proszę Waszą Ekscelencję o łaskawe darowanie mi tego opóźnienia. Muszę na swoje usprawiedliwienie przytoczyć, że w tym wypadku wina moja jest tylko materialna. Po swoim powrocie z Włoch jestem w bezustannej kolizji z czasem swoim, nie mogąc się w porę pozałatwiać ze sprawami, których się tu w czasie mojej nieobecności nagromadziło co niemiara.

Miałem z O. Ledóchowskim trzy długie rozmowy. Oczywiście przede wszystkim poruszona została sprawa O. Siwka. Stanęło na tym, że O. Generał postanowił bezpośrednio znieść się z Waszą Ekscelencją. Uznał tę drogę za najprostszą i za najwłaściwszą. Toteż wycofałem się zupełnie z afery, życząc obu stronom, aby bez trudności ustaliły sposób zakończenia sporu.

Dziękuję za cenne materiały w sprawie Sióstr Niepokalanek. Ponieważ Matka Generalna cofnęła swój wniosek dotyczący księdza Brossa, a niemal równocześnie zrozumiałem z pewnych enuncjacji, że koła urzędowe niechętnie widzą jakąkolwiek ingerencję poza wizytatorem apostolskim, dałem sobie z tą całą niemiłą sprawą święty spokój i poleciłem księdzu Brossowi, aby i on ze wszystkiego się wycofał. Ze Siostrami Niepokalankami, które znam bardzo mało, utrzymuję już tylko stosunki podyktowane mi zwykłymi względami dla tak pięknej polskiej Kongregacji.

Dawno już nie mam żadnych wiadomości o zdrowiu Waszej Ekscelencji. Sądzę więc, że Ekscelencja dobrze się czuje. Wnioskuję to i stąd, że Wasza Ekscelencja zaniechał myśl wyjazdu do Iki. W każdym razie z całej duszy życzę Ekscelencji sił i zdrowia do wykończenia wielkiego dzieła o Chrystusie.

Proszę przyjąć wyrazy najgłębszej czci i oddania, z którym jestem Waszej Ekscelencji

271 Brak podpisu.

${ }^{272}$ Mszps pisany na 2 stronach papieru formatu A4. W lewym górnym rogu nadruk: „Prymas Polski”. W lewym dolnym rogu: „Jego Ekscelencja Najprzewielebniejszy Metropolita Józef Teodorowicz Arcybiskup Ormiański we Lwowie”. 
powolny i oddany sługa w Chrystusie + August Kard. Hlond ${ }^{273}$

47.

FKiDOP, t. 130, sygn. 1585/185 [4], s. 89-90, arcybp J. Teodorowicz do kard. A. Hlondaª ${ }^{274}$.

Wasza Eminencjo!

Bardzo dziękuję za list, który otrzymałem i posyłam Waszej Eminencji kopię do O. Generała ${ }^{275}$.

Listu tego, który on mi przysłał nie rozumiem; bo nawet Siwek nie miałby odwagi w ten sposób przeistaczać rzeczy, jak to uczynił Generał. Mógłbym tu siebie podejrzewać o jaką[[ś] stronniczość, bo o moją sprawę idzie, ale dałem czytać list przyjacielowi Generała, księdzu metropolicie Szeptyckiemu i ten nie mógł wyjść ze zdumienia, iż na coś podobnego zdobył się Generał. Tłumaczę to sobie tym jednym, o czym mówią jezuici sami, że Generał pozostaje pod nieprzepartym wpływem Siwka i że oni sami są zupełnie wobec tego bezradni.

Dziękuję Waszej Eminencji za troskę o moje zdrowie; trzymam się jak na mnie jako tako, ale ja już jestem na odejściu, daleko więcej zależy na zdrowiu Waszej Eminencji niestety bardzo nieszanowanym i bardzo pomiatanym. A jednak tak nam trzeba steru w tych ciężkich chwilach i tak przełomowych, w których zwłaszcza masoneria uderza na młodzież i na wychowanie.

Nowego premiera ${ }^{276}$ znam i uważam go za porządnego człowieka. Obecnie za parę dni wyjadę do Krynicy; mam nadzieję, że się tam skrzepię. Pracuję już od dłuższego czasu nad życiem Chrystusa, które, o ile mi Bóg doda sił, pragnąłbym ukończyć.

Wielka szkoda, że Wasza Eminencja nie może się zająć sprawą SS. Niepokalanek. Niestety, wizytator popierany przez nuncjusza moralnie nie nadaje się do tej roli i boję się bardzo, że chaos i zamieszanie w takich warunkach po prostu może zagrozić temu ze wszech miar tak pożytecznemu Zgromadzeniu.

Prosząc Waszą Eminencję o szanowanie się większe niż dotąd, łączę najoddańsze wyrazy mej czci najgłębszej ${ }^{277}$

Lwów, dnia 19 maja $1934^{278}$

273 Własnoręczny podpis.

274 Mszps pisany na 2 stronach papieru formatu A4.

275 Załącznik do listu nie zachował się.

276 Chodzi o Leona Kozłowskiego (1892-1944), premiera w latach 1934-1935.

277 Brak podpisu.

278 Pod datą dopisano czarnym atramentem: „X Prymas Hlond”. 
48.

FKiDOP, t. 130, sygn. 1591/184 [7], s. 91-92, arcybp J. Teodorowicz do kard. A. Hlonda ${ }^{279}$.

\section{Wasza Eminencjo!}

Byłbym już dawno napisał do Waszej Eminencji, ale czekałem na sposobność porozumienia się z Eksc[elencją] Metropolitą Sapiehą, który właśnie był u mnie wczoraj. Przedłożyłem mu mój projekt zareagowania na rzecz tak dla mnie dotkliwą, jaką była uchwała pomieszczona w protokole w sprawie O. Siwka i mo$j^{2} j^{280}$. Takiego pomieszczenia w protokole sprawy dotyczącej mnie $i$ to sprawy tak dla mnie drażliwej nie mogłem zupełnie zrozumieć, albowiem uchwalona została rezolucja, pomieszczona w protokole, która dotyczy mnie, jakkolwiek pozornie wygląda na odpowiedź daną księdzu. Zdaje mi się jednak, iż trudne jest do pomyślenia, ażeby konferencja biskupów z jednej strony zaszczycała, a z drugiej strony sama siebie zniżała do odpowiedzi na list prywatny księdza przez umieszczenie tego w protokole obrad. Trudno znowu mi przypuścić, że Konferencja działała nieszczerze i pod pozorem odpowiedzi księdzu chciała mi dać nauczkę, a raczej chciała mię poświęcić Generałowi Jezuitów, w tej chwili toczącemu ze mną walkę.

Wasza Eminencja zrozumie, że mam najzupełniejszą słuszność, jeżeli się czuję podobnym aktem w najwyższym stopniu dotkniętym i jeżeli wyrażam moje zdumienie, ale i moje uczucie wewnętrzne, że stoję przed faktem jak przed zagadką.

Po rozmowie z Księciem Arcybiskupem Sapiehą, który uznał pomieszczenie w protokole tej sprawy za gruby nietakt wobec mojej osoby, dochodzę do przekonania, że zarówno on jak i Wasza Eminencja nie zwrócił uwagi na protokół. Może być, iż był tylko w tym czynny albo suchy biurokratyzm, albo też, co jest bardziej prawdopodobne, ręka jednego z Księży Biskupów, specjalnie zainteresowanego w tej sprawie. Może być, że są to moje nieuzasadnione domysły, które jednak faktu samego nie zmieniają w niczym, iż rezolucja podobna znajduje się w protokole.

Otóż po porozumieniu się z Księdzem Arcybiskupem Sapiehą, któremu przeczytałem projekt mojej odpowiedzi, przesyłam tę odpowiedź Waszej Eminencji

${ }^{279}$ Mszps pisany na 2 stronach papieru formatu A4. Na pierwszej stronie w prawym górnym rogu dopisano odręcznie: „kopia”.

${ }^{280}$ „W końcu sierpnia odbędzie się w Poznaniu kongres filozofii tomistycznej. Na ten kongres ma przybyć także jako prelegent o. Siwek z Rzymu. To uważa ks. Bogdanowicz ze Lwowa za rzecz przykrą ze względu na spór toczący się między ks. Siwkiem a arcybpem Teodorowiczem. Ks. Prymas, do którego ks. Bogdanowicz się zwrócił odpowie mu, że sprawa ks. arcybpa Teodorowicza i o. Siwka jest ich prywatną sprawą". Archiwum Kurii Metropolitalnej Krakowskiej, sygn. TS XII/ 139, Protokół Konferencji Komisji Prawnej Episkopatu Polski, Warszawa 19-20 czerwca 1934, k. 290. 
z prośbą, ażeby była w całości ${ }^{281}$ odczytana na Konferencji Księży Biskupów. W każdym razie proszę, ażeby Wasza Eminencja zechciał mię zawiadomić, czy się godzi, by załączone tu pismo było na Konferencji oczytane.

Przy tej sposobności muszę zauważyć, że pisząc ostatni list w tej sprawie do Waszej Eminencji myślałem, że to Księża Biskupi zapraszają Ojca Siwka, a nie Komitet złożony z trzech członków; nic też o tym nie wiedziałem, że referat O. Siwka już został opublikowany w streszczeniu, czyli że nie wiedziałem o tych szczegółach, które uniemożliwiałyby zupełnie Waszej Eminencji uchylenie referatu O. Siwka na zjeździe tomistycznym ${ }^{282}$.

Łączę dla Waszej Eminencji wyrazy mej najgłębszej czci283

Lwów, dnia 11 sierpnia $1934^{284}$

[Załącznik - pismo arcybpa J. Teodorowicza skierowane do Księży Biskupów ${ }^{285}$ ]

Wasza Eminencjo! ${ }^{286}$

W protokole ostatniej konferencji Komisji prawnej została pomieszczona rezolucja, która podkreślała brak łączności sporu mojego naukowego z O. Siwkiem a zaproszeniem O. Siwka z referatem do Poznania. Ponieważ rezolucja dotyczyła mojej sprawy, której skutkiem mej nieobecności na konferencji wyjaśnić nie mogłem, przeto określam ex post moje stanowisko, ażeby ustrzec je przed wszelką dwuznacznością.

Istotnie, gdzie Księża Biskupi w ogóle nie są powołani do komitetu urządzającego kongres międzynarodowy tomistyczny i gdzie jedynie członkiem tego komitetu jest Ksiądz Prymas, któremu przedstawiono gotowe już referaty ogłoszone w dziennikach, tam łączenie jakiejkolwiek sprawy sporu naukowego między mną a O. Siwkiem nie może być brane w rachubę. Dodatkowo tylko zaznaczam, że mój spór naukowy z O. Siwkiem jakkolwiek ma za tło Konnersreuth, toczył się nie o Konnersreuth, ale o metody w badaniach mistycznych, orzekające o zjawiskach mistycznych z pominięciem zupełnym kryteriów mistycznych o przesądzeniem o nich przez analogie psychopatyczne. Szło mi więc nie o Konner-

281 „W całości” - wyrazy podkreślone.

282 Międzynarodowy Kongres Tomistyczny odbył się w dniach 28-30 sierpnia 1934 roku w Poznaniu. Zgromadził czołowych filozofów z różnych ośrodków naukowych Europy (Paryż, Rzym, Mediolan) oraz polskich uczonych. O. Paweł Siwek SJ wygłosił referat pt. „Reinkarnacja i jej wynikłości moralne w świetle filozofii”. K. Kowalski, Międzynarodowy Kongres Filozofii Tomistycznej w Poznaniu, „Collectanea Theologica”, 16, 1935, 1, s. 134-139.

283 Brak podpisu.

${ }^{284}$ Pod datą: „J[ego] Em[inencja] Ks. Kardynał Prymas Dr August Hlond”.

${ }^{285}$ FKiDOP, t. 130, sygn. 1592/184 [7], s. 105-107, mszps pisany na 3 stronach papieru formatu A4. W zbiorach FKiDOP znajdują się jeszcze trzy kopie tego pisma $\mathrm{z}$ datą 11 i 23 sierpnia 1934 roku.

286 „Eminencjo” - dopisano odręcznie. 
sreuth, jak to wyraźnie zaznaczyłem, ale o metody podważające w ogóle mistykę i wszelką pewność co do prawdziwości wszystkich stanów mistycznych.

Nie mogę przy tym i tego pominąć, iż obok sporu naukowego, spór ten dotyczył kwestii z nauką nic nie mającej wspólnego, bo kwestii moralnej. Między innymi spór ten narzucił pytanie, czy jest dozwolona tego rodzaju polemika publiczna zakonnika z biskupem, w której ten zakonnik pomieszczając wyjątki z listów pisanych do niego przez tego biskupa, fałszuje ich znaczenie i sens, tak samo jak tendencyjnie przekręca teksty tez naukowych biskupa, ażeby w ten sposób wykazać ignorancję biskupa? Czy jest dalej dozwolony publiczny atak oparty o przekręcenie tekstu zakonnika na biskupa, zarzucający biskupowi błąd contra doctrinam christianam w kwestii tak zasadniczej jak proroctwa? Czy jest w końcu dozwolone, ażeby zakonnik ów na wykładzie publicznym w Rzymie ${ }^{287}$ kpił z tego biskupa wśród międzynarodowego audytorium, wymieniając jego nazwisko i pozwalając sobie na uwagi, że jeśli kto nie ma wyobrażenia o rzeczy, ten niech się lepiej do pisania nie bierze i czy podobne, bądź co bądź niezwykłe i dotąd nieznane, nie mające precedensu metody, obchodzą li tylko jednego biskupa, czy też wiążą pewną solidarnością i innych?

Poruszam te kwestie czysto teoretycznie, powodowany do tego tekstem protokołu, gdyż ani myślałem, ani też myślę o ile to mnie dotyczy, zajmować Najdostojniejszych Księży Biskupów.

Jeżeli mam jaką[śs] prośbę do Najdostojniejszych Księży Biskupów to tylko tę jedną, ażeby jeżeli ktoś poruszy moją jakąś sprawę i jeżeli konferencja Najdostojniejszych Księży Biskupów będzie uważała tę sprawę aż za tak ważną, że rezolucję odnoszącą się do mnie zechce pomieścić w protokole, to w takim razie gdyby się coś podobnego zdarzyło, będę bardzo zobowiązany Najdostojniejszym Księżom Biskupom, jeżeli z taką kwestią wprzód do mnie się zwrócą o wyjaśnienie ${ }^{288}$

Lwów, dnia 11 sierpnia $1934^{289}$

49.

ASIK, $A H$, t. V, cz. 28, s. 155-156, arcybp J. Teodorowicz do kard. A. Hlonda ${ }^{290}$.

$27 \operatorname{grud}[$ nia] 1934

Wasza Eminencjo,

Bardzo dziękuję Waszej Eminencji za łaskawy list i troskę o moje zdrowie, które nad wszelkie spodziewanie jest przynajmniej w tej chwili dobre. Siedzę

287 „W Rzymie” - dopisano odręcznie.

288 Brak podpisu.

289 Pod datą: ,J[ego] Em[inencja] Kardynał Prymas Dr August Hlond”.

${ }^{290}$ Mszps pisany na 2 stronach formatu A4. 
jak prawdziwy Emeryt w swoim kąciku we Lwowie, mam prawie przygotowany dalszy tom do druku, który się zajmuje Starym Testamentem i pródami wśród Żydów w czasie wystąpienia Chrystusa Pana. Tkwię tak w Żydostwie, że chyba wkrótce zamiast piuski zacznę nosić jarmułkę, a zamiast rewerendy chałat. Ale po książce Zielińskiego „Hellenizm a judaizm”291 i wśród prądów obecnych idących z Niemiec, przy kompletnej ignorancji naszej inteligencji, uważałem za potrzebne osobno ten dział opracować.

W sprawie księdza Brossa rozumiem zupełnie stanowisko Waszej Eminencji. Nie jest tylko jasne ustąpienie O. Gościńskiego ${ }^{292}$. Ksiądz Biskup Barda ${ }^{293} \mathrm{mi}$ opowiadał, że gdy był w Rzymie w Kongregacji, powiedziano mu już wówczas (tj. w kwietniu b[ieżącego] r[oku]) że Ojciec św. zgodził się na jego ustąpienie i Sekretarz rozmawiający z Ks. Biskupem Bardą polecił przynieść odnośne pismo. Pomimo tego O. Gościński dzięki jakiejś niezwykłej protekcji utrzymał się na stanowisku Wizytatora, powiedział Siostrom, że jego sprawa wisiała już na włosku, ale w ostatniej chwili został uratowany.

Teraz jednak jak przypuszczam pod wpływem rewelacji Siostry Fidei ${ }^{294}$, został definitywnie usunięty. Tłumaczył się przed Siostrami, że właściwie nie ma już potrzeby u nich dalszej Wizytacji, on zaś zostaje powołany do ważnej misji we własnym Zgromadzeniu. W każdym razie posyłam Waszej Eminencji odpis polski pisma, które Siostra Fidea posłała do Rzymu ${ }^{295}$. Za wiarygodność Siostry Fidei biorę pełną odpowiedzialność. Wasza Eminencja sam się z tego pisma przekona, jakich to Wizytatorów wybierają w Rzymie, nie odnosząc się zupełnie do polskich Biskupów.

291 T. Zieliński, Hellenizm a judaizm, 1-2, Kraków 1927.

${ }^{292}$ Ludwik Rajner Gościński (1890-1969) - franciszkanin konwentualny, święcenia kapłańskie otrzymał w 1918 roku, ceniony rekolekcjonista, gwardian klasztoru w Poznaniu (1927-1930) oraz Kaliszu (1933-1934), wizytator Zgromadzenia Sióstr Niepokalanego Poczęcia NMP (1931-1934). W 1934 roku opuścił zakon. J. Bar, Gościński Rajner Ludwik, w: $S P P F$, s. 151-152.

${ }^{293}$ Franciszek Barda (1880-1964) - święcenia kapłańskie otrzymał w 1904 roku w Krakowie, wykładowca w seminarium duchownym w Krakowie (1910-1914) i Poznaniu (19191925), rektor Instytutu Polskiego w Rzymie (1925-1928), rektor seminarium duchownego w Krakowie (1930-1931), biskup pomocniczy diecezji przemyskiej (1931-1933), ordynariusz przemyski (1934-1964). K. Kras ow ski, Biskupi katoliccy II Rzeczypospolitej, s. 26-27.

${ }^{294}$ Maria Kapri (1893-1985) - w 1916 roku wstąpiła do Zgromadzenia Sióstr Niepokalanego Poczęcia NMP (niepokalanek) i otrzymała imię Fidea, w 1923 roku złożyła śluby wieczyste, w 1934 roku opuściła zgromadzenie; pracowała między innymi jako sekretarka arcybiskupa Teodorowicza, po drugiej wojnie światowej uczyła języków obcych w seminarium duchownym diecezji opolskiej; prześladowana przez Urząd Bezpieczeństwa. Informacje uzyskane od s. Janiny Martynuski CSIC, Szymanów, 15 stycznia 2015 roku.

295 Załącznik do listu nie zachował się. 
Przy tej sposobności donoszę Waszej Eminencji o epizodzie walki między Legionem Młodych ${ }^{296}$ a Młodzieżą Narodową ${ }^{297}$. Powodem tej walki był atak na moje przemówienie do Młodzieży ze strony Legionu Młodych. Atak ten właściwie nie miał charakteru religijnego i można było śmiało nie przywiązywać do niego wielkiej wagi, ale młodzież katolicka postanowiła skorzystać z tego ataku, ażeby stanąć w obronie już nie tyle mojej, ale zasad katolickich i religii deptanej przez Legion Młodych. Urządzono wiec w Szkole Wyższej Handlowejejes, w której była główna siedziba Legionu Młodych. Na ten wiec przybyła młodzież katolicka i narodowa w niepamiętnej liczbie. Szczególniejsza rzecz, że na ten wiec przybył i sam Rektor ${ }^{299}$, wychrzta, człowiek zresztą chwiejny. Rezolucje powzięte na tym wiecu załączam do listu ${ }^{300}$.

Ze strony Legionu Młodych przemawiał Hirazler ${ }^{301}$, zdaje mi się, że żyd ${ }^{302}$, który publicznie oświadczył, że tam gdzie chodzi o rację stanu, przejdą oni ponad Bogiem. Zaraz po tej mowie, w parę dni, dostał intratną posadę rządową w jednym z Banków.

Pokazywała mi młodzież wiersze ulotne Legionu Młodych, tchnące takim bluźnierstwem przeciw Chrystusowi i Krzyżowi, że czegoś podobnego nie czytałem. Objeżdżają też wioski i demoralizują młodzież wiejską. Skoro tylko dostanę przemówienie członków Młodzieży Katolickiej ${ }^{303}$ prześlę je Waszej Eminencji.

Sądzę, że ten epizod, z pominięciem oczywiście mnie, należy wykorzystać, bo to $\mathrm{z}$ jednej strony jest dowód in flagranti ${ }^{304}$ bezbożności Legionu, publicznie już wyznawanej - z drugiej strony jest objaw reakcji samej że młodzieży. To pod pewnym względem znaczy bardzo wiele $\mathrm{w}$ związku z odezwaniami się Biskupów.

${ }^{296}$ Legion Młodych, właściwie: Akademicki Związek Pracy dla Państwa - organizacja akademicka związana z sanacją; funkcjonowała w latach 1930-1939.

${ }^{297}$ Właściwie: Narodowa Organizacja Gimnazjalna, znana też pod nazwą Organizacja Młodzieży Narodowej - organizacja młodzieżowa związana z endecją, działała w latach 1927-1939.

298 Od 1933 roku uczelnia nosiła nazwę: Szkoła Główna Handlowa w Warszawie.

299 Chodzi o Bolesława Miklaszewskiego (1871-1941) - polskiego uczonego i polityka, rektora Wyższej Szkoły Handlowej i Szkoły Głównej Handlowej w Warszawie (1925-1928, 1932-1937), ministra wyznań religijnych i oświecenia publicznego (1923-1924), senatora IV i V kadencji.

300 Załącznik do listu nie zachował się.

301 Postać niezidentyfikowana, być może: Hirszler.

302 Pisownia zgodna z oryginałem.

303 Właściwie: Katolickie Stowarzyszenie Młodzieży - powołane podczas krajowego zjazdu Akcji Katolickiej w 1934 roku w Krakowie, prowadziło działalność religijno-patriotyczną i społeczno-kulturalną pod hasłem: „Budujmy Polskę Chrystusową”.

304 Łac.: na gorącym uczynku. 
$\mathrm{K}$ [atolicka] A[gencja] $\mathrm{P}$ [rasowa] o tym wszystkim ani wspomniał[a] - nie winię jej ${ }^{305}$ zresztą, bo może nie miał[a] informacji, ale trzeba będzie wpłynąć na $\mathrm{K}$ [atolicką] $\mathrm{A}$ [gencję] $\mathrm{P}$ [rasową], ażeby intensywnie ten epizod wykorzystał[a].

Zasyłam Waszej Eminencji z okazji Świąt i Nowego Roku najserdeczniejsze i najgorętsze życzenia zwłaszcza dobrego zdrowia, na którym nam wszystkim tak bardzo zależy.

Całując pierścień Waszej Eminencji łączę najgłębsze wyrazy czci

+ Teodorowicz

50.

FKiDOP, t. 130, sygn. 119/19 [6], s. 108, arcybp J. Teodorowicz do kard. A. Hlonda ${ }^{306}$.

\section{Wasza Eminencjo!}

Odpowiadam na łaskawy list Waszej Eminencji i nic nie mam przeciwko temu, aby w miejsce ks. Bogdanowicza wszedł ktoś inny świecki; proponuję pana Dąbrowskiego Stefana, o ile by zaś on nie mógł, to profesora Lisowskiego ${ }^{307}$.

Łączę przy tej sposobności dla Waszej Eminencji, ponawiając moje życzenia, wyrazy zawsze oddane najgłębszej czci ${ }^{308}$

Lwów, dnia 2 stycznia $1935^{309}$

51.

FKiDOP, t. 130, sygn. 55/19 [6], s. 109-110, arcybp J. Teodorowicz do kard. A. Hlonda ${ }^{310}$.

Wasza Eminencjo!

Niezmiernie jestem Waszej Eminencji zobowiązany, iż raczył przyobiecać $\mathrm{p}$ [ani] Gromskiej ${ }^{311}$ interwencję w sprawie wydania mojego dzieła w języku włoskim. Gdyby się to udało, to byłbym niezmiernie z tego rad, gdybym mógł Ojcu św. w roku jubileuszowym tę moją pracę przesłaćci12.

305 W oryginale: „go".

306 Mszps pisany na 1 stronie papieru formatu A4.

307 Zygmunt Lisowski (1880-1955) - prawnik, profesor prawa rzymskiego, związany z Uniwersytetem Poznańskim. J. Wąsicki, Lisowski Zygmunt, w: Wielkopolski słownik biograficzny, red. A. Gąsiorowski, J. Topolski, Warszawa-Poznań 1981, s. 427.

308 Brak podpisu.

309 Pod datą: „Ks. Prymas Hlond”.

310 Mszps pisany na 2 stronach cienkiego papieru formatu A4.

311 Janina Gromska (1877-1966) - tłumaczka literatury polskiej na język włoski, między innymi utworów Bolesława Prusa, Henryka Sienkiewicza, Władysława Reymonta.

312 Chodzi o pierwszy tom dzieła o życiu Chrystusa pt. Od Betlejem do Nazaretu (Poznań 1932). Przedsięwzięcia tłumaczenia i edycji w języku włoskim nie udało się sfinalizować. 
Przy tej sposobności pozwalam sobie dołączyć dla Waszej Eminencji list ${ }^{313}$ $\mathrm{p}$ [ani] dr Skowrońskiej ${ }^{314}$, którą poznałem tego roku w Krynicy. Jest to osoba prawdziwie wielkiej wartości, która kojarzy w sobie prawdziwe życie mistyczne z pełnym poświęcenia apostolstwem. Ma ona w swym zarządzie archiwum kościelne w dokumentach z Rosji, które leżą po prostu odłogiem, gdyż nie ma pracowników naukowych, którzy by się tą sprawą na dobre zajęli; archiwum to jest wprost kolosalne. List jej, który tu załączam wyjaśni Waszej Eminencji tę sprawę bliżej i na razie chodzi tylko o to, aby Wasza Eminencja za pobytu swego w Warszawie wezwał p[anią] Skowrońską do siebie na rozmowę. Ona mi w Krynicy przedstawiła jeszcze bliższy plan swojego projektu, ale myślę, że zajmowanie tym Waszej Eminencji w obecnej chwili będzie przedwczesne i zbyteczne.

Posłałem Waszej Eminencji pewne informacje związane ze sprawą Niepokalanek i sądzę, iż po tym doświadczeniu ostatnim nie należałoby je narażać na nowe, niepewne eksperymenty.

Korzystam ze sposobności, ażeby całując pierścień Waszej Eminencji dołączyć wyrazy bardzo oddane mojej czci najgłębszej315

Lwów, dnia 4 lutego $1935^{316}$

52.

ASIK, $A H$, t. IV, cz. 21, s. 84, kard. A. Hlond do arcybpa J. Teodorowicza ${ }^{317}$.

Ekscelencjo!

Dziękuję za łaskawy list z 4 bm. Chętnie z p[anią] Skowrońską pomówię. Jest to bardzo wartościowa siła fachowa i doskonała katoliczka. Organizacja archiwów kościelnych to przede wszystkim kwestia finansowa. Mimo trudności, w ostatnich latach niejedno się w tej dziedzinie zrobiło w Gnieźnie, Poznaniu, Płocku, Pelplinie. Kraków chętnie by co[ś] uczynił, gdyby miał dom i pieniądze.

Sprawą włoskiego wydania I tomu życia Chrystusa Waszej Ekscelencji już zainteresowałem pewne firmy włoskie. Chcą mieć cały manuskrypt, by się zdecydować. Czekam więc, aż p[ani] Gromska skończy tłumaczenie.

Łączę wyrazy najgłębszej czci i oddania

313 Załącznik do listu nie zachował się.

314 Zofia Olszamowska-Skowrońska (1892-1983) - historyk, badacz dziejów Kościoła katolickiego w zaborze rosyjskim, pracownik Archiwum Głównego Akt Dawnych w Warszawie; przez wiele lat prowadziła kwerendę w archiwach watykańskich; autorka licznych publikacji naukowych, w tym edycji źródłowych i tłumaczeń. H. Fokciński, Wspomnienie o Zofii Olszamowskiej-Skowrońskiej, „Kronika Rzymska”, 1983, 2, s. 13-15.

315 Brak podpisu.

316 Pod datą: „Ks. Kardynał Prymas Hlond-Poznań”.

317 Mszps pisany na 1 stronie formatu A4. 


\section{$\mathrm{Hl}[$ ond $]$ \\ $\mathrm{P}$ [oznań], d[nia] 11/2 [19]35}

53.

ASIK, $A H$, t. V, cz. 28, s. 167-170, arcybp J. Teodorowicz do kard. A. Hlonda ${ }^{318}$.

\section{Wasza Eminencjo!}

Stokrotne dzięki za zajęcie się aż tak intensywnie sprawą mego dzieła. Tłumaczenie jest już dawno skończone i skoro już Wasza Eminencja Sam chciał wziąć na Siebie ten kłopot, przesyłam na ręce Waszej Eminencji jeden egzemplarz.

Cieszę się niezmiernie, że Bóg natchnął Waszą Eminencję myślą opracowania własnego projektu dla synodu ${ }^{319}$; jest to jedyne wyjście $\mathrm{z}$ beznadziejnej sytuacji w jakiej ugrzęźliśmy, a zarazem po tych dwu projektach odnosi się wrażenie, jak gdyby z dusznej zatłoczonej izby wyszło się na wolne, szerokie, przestronne miejsce i powietrze. Przeszedłem cały projekt punkt po punkcie z dwoma kanonistami i jest w całości wzięty znakomity. Przede wszystkim nigdzie w nim nie ma fałszywego tonu, jednostronności i drobiazgowości ciasnej jaką grzeszyły projekty poprzednie. Przy tym we wszystkim w szczegółach, jak [w] całości, przetyka szeroki duch kapłański i apostolski z uwzględnieniem naszych potrzeb i czasów. Dlatego gorąco dziękuję Waszej Eminencji za ten projekt, który rozwiązuje tak szczęśliwie w ogóle sprawę synodu. Potrzebne moim zdaniem poprawki dotyczyć będą głównie ściślejszego prawnego ujęcia niektórych kwestii; parę stylistycznych niejasności, parę zbytecznych może drobiazgów, parę powtarzań się, to zaś już drobnostki dające się uwzględnić bez wszelkich trudności. Jeden z prawników, który znał poprzednie projekty określił je w ten sposób: pierwszy projekt mówiący głównie o „trawie i pszenicy” był projektem gospodarskim ${ }^{320}$; drugi był projektem policyjnym ${ }^{321}$; trzeci to projekt ascetyczny ${ }^{322}$.

Dołączam przy tej sposobności Waszej Eminencji pismo moje do nuncjusza, gdyż może Wasza Eminencja widząc się w Warszawie z nuncjuszem będzie

318 Mszps pisany na 4 stronach formatu A4.

319 Pierwszy Synod Plenarny w Polsce odbył się w dniach 25-26 sierpnia 1936 roku w Częstochowie z udziałem legata papieskiego kardynała Francesco Marmaggiego. W trakcie obrad poruszono szereg ważnych problemów ówczesnego życia religijnego i kwestii organizacyjnych Kościoła: sakramentów, kultu, misji katolickich, nauczania katechezy, duszpasterstwa, organizacji wydawnictw katolickich, zasad moralnych w życiu publicznym, duchowieństwa, roli osób świeckich w Kościele, uposażenia materialnego Kościoła itp. Uchwały I Polskiego Synodu Plenarnego odbytego w Częstochowie w dniach 26-27 VIII 1936 oraz orędzie Episkopatu Polskiego w sprawie uchwat synodu, Poznań 1938, passim.

320 Wyraz podkreślony.

321 JW.

$322 \mathrm{JW}$. 
uważał za stosowne poruszyć z nim tę sprawę. Zgłosił się do mnie X. Wysoczański $^{323}$ administrator naczelny starokatolików i podając mi spis ich parafii w Małopolsce i na Wołyniu prosił mnie o przyjęcie ich pod moją jurysdykcję. Ogólna suma wiernych wynosi około 15 tysięcy. Księża łacińscy oddają Wysoczańskiemu bardzo dobre świadectwo jako człowiekowi, który już przedtem czynnie działał na rzecz katolicyzmu. Rekrutują się te parafie częścią ze starorusinów, którzy przeszli na starokatolicyzm skutkiem nacisku politycznego ukrainizmu, tak jest w Małopolsce; częścią ze schizmatyków niezadowolonych ze swych popów na Wołyniu. Za warunek stawiają oni: pozostanie przy swoim wschodnim obrządku z przynależnością do mnie jako biskupa obrządku wschodniego. X. Wysoczański ma święcenia [od] biskupa starokatolickiego konsekrowanego przez biskupa w Utrechcie, a więc święcenia ważne. Co do innych księży, to zbieram jeszcze informacje. Trudność będzie z księżmi apostatami wobec rygoru praw rzymskich. Twierdzi X. Wysoczański, który mi dał podpisy członków jednej parafii, że jeśli się ten ruch ku katolicyzmowi zacznie, to przejdzie i Łemkowszczyzna; nagli on na pośpiech ze względu na agitację schizmatyckich popów, którzy już się dowiedzieli o jego krokach. Podobno mieli z początku przejść na obrządek słowiański i już się zwracali do biskupa Szelążka ${ }^{324}$ i Fulmana ${ }^{325}$, ale ta rzecz jest mi trochę niejasna.

${ }^{323}$ Ignacy Jan Wysoczański (1901-1975) - ukończył seminarium greckokatolickie w Dubnie na Wołyniu i przyjął święcenia diakonatu w tym obrządku (1930), święcenia kapłańskie otrzymał od zwierzchnika Kościoła starokatolickiego biskupa Władysława Farona (1931), pracował duszpastersko w parafii starokatolickiej obrządku wschodniego w miejscowości Twerdyń na Wołyniu; w 1935 roku zwrócił się do arcybiskupa Teodorowicza z prośbą o przyjęcie pod jego jurysdykcję, do czego jednak nie doszło; pracował również w parafiach Wschodniego Prawosławnego Katolickiego Kościoła Apostolskiego; w 1936 roku skazany na karę więzienia za nielegalne udzielanie ślubów i rozwodów; w 1943 roku przyjął sakrę biskupią w Konstantynopolu w obrządku koptyjskim, po drugiej wojnie światowej został biskupem Polskiego Kościoła Starokatolickiego. Wiadomo, że przyjął dwa razy święcenia kapłańskie oraz trzy sakry biskupie; był też czterokrotnie żonaty. K. Bielawny, Ignacy Wysoczańskibiskup Kościoła Starokatolickiego i Kościołów Wschodnich, w: Biskup - prezbiter - diakon. Perspektywa polskokatolicka i rzymskokatolicka, red. J. Jezierski, Olsztyn 2008, s. 187-199; S. Pastuszewski, Kapłan wagabunda na Zamojszczyźnie, „Archiwariusz Zamojski”, 2013, 12, s. 69-80.

324 Adolf Szelążek (1865-1950) - święcenia kapłańskie otrzymał w 1888 roku w Płocku, wykładowca seminarium duchownego w Płocku i Petersburgu, biskup pomocniczy płocki (1918-1925), od 1925 roku biskup diecezji łuckiej na Wołyniu; w czasie drugiej wojny światowej więziony przez Sowietów, a następnie deportowany do Polski. P. Nitecki, Biskupi Kościoła w Polsce, s. 428.

325 Marian Fulman (1866-1945) - święcenia kapłańskie otrzymał w 1889 roku we Włocławku, za działalność patriotyczną uwięziony przez władze carskie, proboszcz w Częstochowie, ordynariusz diecezji lubelskiej (1918-1945); współtwórca i pierwszy kanclerz Katolickiego Uniwersytetu Lubelskiego; w czasie drugiej wojny światowej aresztowany przez 
W całości jest to dla mnie duży kłopot, ale nie uchylam się, nie mogąc brać odpowiedzialności za odmowę. Zdaje mi się, że poruszanie tej kwestii w obecnej wstępnej i niedojrzałej fazie na Konferencji Prawnej nie będzie wskazane zwłaszcza wobec niebezpieczeństwa ze strony jednego z księży Biskupów, który gotów by był może polecieć do Rzymu, ofiarować papieżowi 15 tysięcy starokatolików.

W sprawie Niepokalanek pisałem Waszej Eminencji moje zdanie. Po dojrzałym namyśle przychodzę do następującego wniosku: o ile by je miano znowu narażać na fatalne eksperymenty, to istotnie należałoby je raz uwolnić od wizytacji ciągnącej się tyle lat i zakończonej wprost skandalem z Gościńskim. Z drugiej strony mądra i krótka wizytacja byłaby wskazana tylko pod tym warunkiem, gdyby znaleziono do tego człowieka. Jedynym człowiekiem byłby Bross, bo je wybornie zna i dlatego one właśnie się go tak boją. Powody, dla których taka wizytacja byłaby wskazana są następujące:

1sze: Gościński podobno je okradł zabrawszy duży posag jednej zakonnicy. Słyszałem o tym ja, słyszał z innego źródła arcyb[iskup] Twardowski. Jest to tym prawdopodobniejsze, że uciekł z jakąś babą, więc pieniądze mieć musiał. Obecna matka jest choć $\mathrm{w}$ dobrej wierze $\mathrm{w}$ tę całą aferę zaangażowana przez swego brata.

2. Gościński prowadził romans ze Szczęsną 326 , tą samą, którą biskup Przeździecki wyrzucił za romans z katechetą i która przechwalała się miłosnymi listami wizytatora szkolnego z Warszawy, dziś zaś opowiadaniami swoimi kompromituje nieostrożnego nuncjusza posyłającego jej bilety noworoczne etc. Nie tylko daje do poznania, ale wprost w kołach warszawskiej arystokracji do której z urodzenia należy mówi o tym, że nuncjusz się w niej kocha etc. Otóż tę Szczęsną, osobę przy tym płytką a intrygantkę i obciążoną dziedzicznie po matce erotomankę. Otóż tę Szczęsną ze współudziałem nuncjusza powołał G[ościński] na stanowisko asystentki zgromadzenia, gdyż ona dobrała sobie matkę generalną i skład rady. Takie stosunki są zupełnie amoralne.

3. Wskutek długoletniej wizytacji Trzemeskiego wkradł się do zgromadzenia duch szpiegostwa, dzielenie zakonnic na dwie kategorie: schlebiające przełożonej i więcej bogatsze, a przy tym absolutyzmu gniotącego wszelką wolność indywidualną i oczywiście przeciętny ${ }^{327}$ wizytator nic na to nie pomoże, raczej zaszkodzi.

4. Fatalny jest stosunek do drugiego chóru. Podam przykład. Tu pracuje w szwalni żydowskiej za 45 złotych miesięcznie głodując zakonnica II chóru czasowo wypuszczona z klasztoru, tylko dlatego, że klasztor nie chciał dać drobnej

Niemców i umieszczony w obozie koncentracyjnym w Sachsenhausen. P. Nitecki, Biskupi Kościoła w Polsce, s. 105-106.

326 Szczęsna Natalia Sulatycka (1884-1966) - niepokalanka, w zgromadzeniu pracowała jako nauczycielka i wychowawczyni. Informacje uzyskane od s. Janiny Martynuski CSIC, Szymanów, 15 stycznia 2015 roku.

327 Wyraz podkreślony. 
subwencji dla jej ojca pozbawionego środków do życia. Równocześnie wydają [znaczne] sumy zakonnice na kosztowne ornaty dla nuncjusza, by pozyskać jego względy. To wszystko jest niezdrowe i zaprawione nie bożym, ale ludzkim duchem. O panowaniu ludzkiego ducha w zarządzie zgromadzenia mówiła na łożu śmierci poprzednia matka generalna ${ }^{328}$. Obok tego jest pełno ślicznych powołań osób nie wiedzących nic o tym, co się za dawnym murem dzieje.

Dołączam Waszej Eminencji ciekawe uchwały księży ${ }^{329}$ w sprawie bardzo dawnej, bo w sprawie kolportażu, którą czy warto poruszyć na zebraniu Księży biskupów.

Łączę przy tej sposobności dla Waszej Eminencji wyrazy najoddańszej czci najgłębszej

+ Teodorowicz

Lwów 15/II [1]935

\section{[Załącznik]}

abp Józef Teodorowicz do arcybpa Francesco Marmaggi330

Excellence,

Il y e quelques semaines, un ecclésiastique de la section de Vieux Catholiques (Societas Neoprotestantica Vaterum Catholicorum) vint s'adresser à moi, se déclarant pret au retour à l'union avec l'Eglise Catholique, de meme que plusieurs autres d'entre leur clergé et leurs fidèles. Après m'etre longuement entretenu avec lui, $\mathrm{j}$ 'appris de sa bouche meme que ces fidèles appartenaient autrefois au schisme et leurs ancetres, jadis polonais, professaient sans mul doute la foi catholique.

Ils desirént aujourd' hui a'unir s'unir à l'Eglise Catholique, mais à deux conditions:

1. de pouvoir garder leur rite oriental,

2. d' appartenir à mon diocèse arménien.

Pour entrer plus avant dans l'affaire, j'ai exigé d'eux qu'ils en fournissent par écrit des détails plus précis. Il y a quelques jours, ils m’ont donc envoyé les détails suivants. Le nombre des fidèles désirant embrasser le catholicisme remonte à 20000 , celui des ecclésiastique comprend 9 pretres.

328 Matka Wawrzyna Maria Szaszkiewicz (1858-1932) - przełożona generalna niepokalanek (1922-1932). Informacje uzyskane od s. Janiny Martynuski CSIC, Szymanów, 15 stycznia 2015 roku.

329 Załącznik do listu nie zachował się.

${ }^{330}$ Francesco Marmaggi (1876-1949) - włoski duchowny katolicki, święcenia kapłańskie otrzymał w 1900 roku, urzędnik Kurii Rzymskiej, dyplomata watykański, nuncjusz apostolski w Polsce (1928-1935), prefekt Kongregacji ds. Duchowieństwa (1939-1949), od 1935 roku kardynał; odznaczony Orderem Orła Białego. Hierarchia Catholica, 9, s. 38. 
Une partie d'entre eux se trouve actuellement sur le territoire de la Petite Pologne (Małopolska), une autre sur celui de Lublin et de Łuck.

Puisque les pétitionnaires se refusent absolument à s'inféoder à un autre diocèse, je pense qu'il n'existe aucun obstacle à ce que je les accepte sous ma juridiction, si cela s'accorde avec la volonté du Saint-Siège.

Avant que j'amasse plus de détails concernant l'affaire sous-mentionnée (je recueille en ce moment les donnèes concernant les ecclésiastiques), je m'adresse à votre Excellence avec la prière de bien vouloir m'exprimer votre précieux avis là-dessus et de vouloir m'indicuer la procédure, qu'il faudrait y suivre.

Veuillez agréer, Excellence, l'expression de ma plus profonde vénération

Lwów le 15 II 1935

54.

ASIK, $A H$, t. V, cz. 28, s. 171, arcybp J. Teodorowicz do kard. A. Hlonda ${ }^{331}$.

\section{Wasza Eminencjo!}

Równocześnie z listem Waszej Eminencji udałem się na pocztę za recepisą list do nuncjusza w sprawie starokatolików, którego odpis Waszej Eminencji przesłałem ${ }^{332}$. Ponieważ w międzyczasie otrzymałem wiadomość, która w wątpliwość poddaje szczerość tych co się udali do mnie z prośbą o przyjęcie, list do nuncjusza w ostatniej chwili z poczty wycofałem. Wobec tego raczy Wasza Eminencja uważać tę sprawę za przesądzoną i nie istniejącą. O ile by się rzecz odmieniła po zbadaniu bliższym, pozwolę sobie Waszą Eminencję o tym powiadomić.

Łączę najserdeczniejsze wyrazy czci najgłębszej dla Waszej Eminencji

+ Teodorowicz

Lwów, d[nia] 15/II [1]935

55.

FKiDOP, t. 136, sygn. 64/19 [6], s. 6, arcybp J. Teodorowicz do kard. A. Hlonda ${ }^{333}$.

Eminencjo!

Dziękuję za łaskawe zaproszenie, proszę zarazem mieć mnie za wymówionego, iż z powodu stanu zdrowia, obecnie do Warszawy przybyć nie mogę.

${ }^{331}$ Mszps pisany na 1 stronie formatu A4.

332 Zob. załącznik do listu arcybiskupa J. Teodorowicza do kardynała A. Hlonda z 15 lutego 1935 roku w niniejszej edycji.

${ }^{333}$ Mszps pisany na 1 stronie formatu A4. 
Łączę przy tej sposobności dla Waszej Eminencji wyrazy najgłębszej i najoddańszej czci ${ }^{334}$

Lwów, dnia 19 lutego 1935

56.

ASIK, $A H$, t. V, cz. 28, s. 172, kard. A. Hlond do arcybpa J. Teodorowicza ${ }^{335}$.

Ekscelencjo!

Poznań, dnia 27 lutego 1935 r.

Dziękuję za list z dnia 15 bm. Już pisałem do wielkiego zakładu wydawniczego S[ocieta] E[ditrice] I[nternazionale $]^{336} \mathrm{~W}$ Turynie w sprawie włoskiego wydania pierwszego tomu dzieła Waszej Ekscelencji. Odpowiedź pozwolę sobie zakomunikować.

Pewnie Ekscelencja ma już od ks. Prof. Gerstmana ${ }^{337}$ informacje o pracach prawników w Warszawie. Mieli ciężką pracę, a w niejednej sprawie i bardzo ciężkie stanowisko. Ale podobnie poczyna się wyłaniać właściwa treść, którą się Synod Plenarny zająć powinien.

Smutny koniec wizytatora SS. Niepokalanek przeraził mnie, choć poprzednie jego nieroztropności groziły już czymś złym. Napisałbym do Stolicy św., ale tylko na prośbę Biskupów, którzy mają u siebie klasztory tego zgromadzenia. Byłby to dla mnie tytuł do jasnego przedstawienia całokształtu sprawy.

Załączam bardzo serdeczne pozdrowienia i jestem całą duszą Waszej Ekscelencji oddany sługa w Chr[ystusie] $]^{338}$

334 Brak podpisu.

${ }^{335}$ Mszps pisany na 1 stronie formatu A4. W lewym górnym rogu: „Prymas Polski”; w lewym dolnym rogu: „J[ego] E[kscelencja] Najprzewielebniejszy Ks. Arcybiskup Józef Teodorowicz we Lwowie".

336 Società Editrice Internazionale - wydawnictwo zgromadzenia salezjanów założone w 1908 roku w Turynie.

337 Adam Gerstmann (1873-1940) - święcenia kapłańskie otrzymał w 1896 roku we Lwowie, doktor teologii, wikariusz i katecheta gimnazjalny we Lwowie, w 1900 roku habilitował się na Wydziale Teologicznym Uniwersytetu Lwowskiego z zakresu teologii pastoralnej i podjął wykłady jako zastępca profesora Katedry Teologii Pastoralnej z polskim językiem wykładowym; w okresie międzywojennym kierownik katedry teologii moralnej szczegółowej; pełnił kilkakrotnie funkcję dziekana i rektora, był prezesem Koła Księży Prefektów Archidiecezji Lwowskiej. T. Krzyżowski, Ksiądz profesor Mieczysław Tarnawski (18861928). Historyk, wychowawca, patriota, Lwów-Kraków 2012, s. 28-29.

338 Brak podpisu. 
57.

ASIK, $A H$, t. V, cz. 3, s. 124-125, arcybp J. Teodorowicz do kard. A. Hlonda ${ }^{339}$.

\section{Wasza Eminencjo!}

Niezmiernie jestem zobowiązany Waszej Eminencji za starania podjęte w sprawie mojego manuskryptu i raz jeszcze z całego serca za nie dziękuję. Zdaje się, że skończę na tym, iż prześlę Ojcu Świętemu jeden manuskrypt.

Ucieszyły mnie bardzo sprawozdania z Komisji synodalnej warszawskiej, które miałem od bezpośrednich uczestników narad. Główna rzecz była o tym, by raz wyjść z błędnego a beznadziejnego koła. Do tego posłużył projekt Waszej Eminencji, który służy za podstawę zdrową dla synodu. Reszta, to jest ścisła forma prawna, łatwo się odnajdzie, gdy się już ma w ręku właściwe jądro rzeczy. Byle się tylko nazbyt ze wszystkim nie spieszono, a także by i nadto nie poprawiano. Ważną ogromnie sprawą będzie jeszcze projekt rozkładu nauki religii w systemie nowego czteroklasowego gimnazjum. Jeśli przejdzie projekt warszawski, który na naukę wiary i obyczajów przedstawia jeden tylko i to pierwszy rok, (najniepotrzebniej w świecie przeznaczając dwa lata na historię), a przy tym rok na liturgię, wówczas Biskupi sami wygonią religię ze szkoły. Historia kościoła i liturgia powinny mieć tylko rolę pomocniczą, nie zaś rugować samą doktrynę.

Co do Niepokalanek to mówiłem z x. Biskupem Lisowskim ${ }^{340}$ i x. Baziakiem $^{341}$ (arcybiskup ${ }^{342}$ jest obecnie w Muszynie ${ }^{343}$ ), obaj się oświadczają za tym, by Wasza Eminencja sprawę tę wziął w ręce. Nie wątpię, że takie też będzie stanowisko Biskupa Bardy. - Jest tam coraz gorzej. Podobno Benedyktyn Van Ost ${ }^{344}$ się sekularyzuje. Jeśliby to było prawdą i to, że osiada się u nich, to byłoby to dla

339 Mszps pisany na 2 stronach formatu A4.

340 Franciszek Lisowski (1876-1939) - święcenia kapłańskie otrzymał w 1898 roku we Lwowie, katecheta w lwowskich gimnazjach, od 1912 roku profesor teologii dogmatycznej na Wydziale Teologicznym Uniwersytetu Lwowskiego, rektor Seminarium Duchownego we Lwowie (1923-1933), biskup pomocniczy lwowski (1928-1933), ordynariusz tarnowski (1933-1939). J. Wołczański, Wydział Teologiczny, s. 235, przyp. 208.

${ }^{341}$ Eugeniusz Baziak (1890-1962) - święcenia kapłańskie otrzymał w 1912 roku w Przemyślanach, pracował duszpastersko w Żółkwi, Tarnopolu i Stanisławowie, rektor Seminarium Duchownego we Lwowie (1933-1939), biskup pomocniczy archidiecezji lwowskiej (19331944), arcybiskup metropolita lwowski (1944-1962), administrator apostolski archidiecezji krakowskiej (1951-1962). P. Nitecki, Biskupi Kościoła w Polsce, s. 22-23.

${ }^{342}$ Chodzi o metropolitę lwowskiego obrządku łacińskiego Bolesława Twardowskiego.

343 Muszyna - miejscowość wypoczynkowa w Małopolsce.

${ }^{344}$ Karol van Oost (1899-1986) - belgijski benedyktyn, pracujący w Polsce od 1928 roku, związany ze zgromadzeniem niepokalanek w związku z thumaczeniem mszału o. Gaspara Lefebvre'a na język polski, nad którym pracowały siostry z Jazłowca; głosił również rekolekcje dla członkiń tegoż zgromadzenia w Szymanowie. P. Szaniecki, Ojciec Karol Van Oost, Tyniec 1990. 
nich najsmutniejsze. Siostry bowiem się żalą z jednej strony na przymus wywierany przez Przełożoną spowiedzi u niego, a z drugiej strony na zdradzanie przez niego tajemnicy spowiedzi. Oczywiście nie biorę odpowiedzialności za te informacje, choć je otrzymałem świeżo z bezpośredniego otoczenia w Szymanowie ${ }^{345}$. W każdym razie mówiły mi Sacrecoerki ${ }^{346}$ o jego niepoważnym zachowaniu się wobec uczennic za czasu pobytu jego u nich, tak że po roku go usunęły. Podobno to się dziś zaczyna wobec sióstr. Ażeby uchronić się przed wizytacją poszły one za radą przełożonej Samarytanek i wciągają Nuncjusza z jasnym planem zaangażowania jego bezpośredniego. Niestety to im się aż nadto łatwo udaje i stąd powstają nowe zamieszania.

Czy by też Wasza Eminencja nie przywołał do siebie panią Skowrońską dla omówienia kwestii archiwum? To by jej wielką zrobiło przyjemność.

Będę się starał w maju na konferencję przyjechać, gdyż zdrowie moje na to już pozwoli, do kwestii zaś nauczania religii, w której wiele pracowałem, dużą przywiązują wagę.

Obecnie kończę tom, który jest w łączności z moim dziełem o Życiu Chrystusa pod tytułem: podwójne oblicza judaizmu (Stary Testament i faryzeizm ${ }^{347}$ ). U nas o tym pojęcia nie mają, a książka Zielińskiego „Hellenizm a judaizm” wiele narobiła spustoszenia.

Jeszcze raz Waszej Eminencji dziękuję za łaskawość i łączę najoodańsze wyrazy czci najgłębszej.

+ Teodorowicz

Lwów 17/III [1]935

58.

FKiDOP, t. 136, sygn. 171/19 [6], s. 10, arcybp J. Teodorowicz do kard. A. Hlonda ${ }^{348}$.

Wasza Eminencjo!

W roztargnieniu zapomniałem odpowiedzieć Waszej Eminencji na pytanie co do manuskryptu. Proszę najuprzejmiej odesłać mi go do Lwowa.

Przypuszczam, że dzieło niemieckie tłumaczone na język włoski, będzie dziełem Willama ${ }^{349}$, które teraz wszędzie thumaczą na inne języki. Z dominikanami pomówię wedle rady Waszej Eminencji.

345 Szymanów pod Warszawą - dom generalny zgromadzenia niepokalanek.

346 Zgromadzenie Najświętszego Serca Jezusa - Sacre Coeur we Lwowie.

347 J. Teodorowicz, Od Jahwy do Mesjasza, Poznań 1936.

348 Mszps pisany na 1 stronie formatu A4.

349 Franz Michel Willam (1894-1981) - austriacki duchowny rzymskokatolicki, teolog i pisarz, autor przełożonego na wiele języków dzieła o życiu Jezusa: Das Leben Jesu im Lan- 
Jeszcze raz łączę dla Waszej Eminencji najserdeczniejszą podziękę za tak cenne dla mnie dobre chęci, z wyrazami najoddańszymi czci najgłębszej 350

Lwów, dnia 28 marca 1935

59.

ASIK, $A H$, t. V, cz. 8, s. 198, arcybp J. Teodorowicz do kard. A. Hlonda ${ }^{351}$.

Wasza Eminencjo!

Bardzo dziękuję Waszej Eminencji za przysłanie mi Pasterskiego listu o Kościele ${ }^{352}$, o którego przymiotach nie chcę już mówić osobno, a tylko pozwolę sobie zwrócić uwagę na jedno. Ten list jest dopełnieniem listu poprzedniego Waszej Eminencji o Kościele ${ }^{353}$; tamten z natury swej musiał być bardziej teoretyczny, ten zaś wchodzi bezpośrednio w praktykę i daje świetną odpowiedź na wszystkie zarzuty przeciw Kościołowi, w sposób niezmiernie żywy przez argumenty ad hominem ${ }^{354}$, które mimo swej siły i mocy tak są jednak wdzięcznie podane.

Zaniepokojony jestem wiadomością o złym stanie zdrowia Waszej Eminencji, która mię świeżo doszła. Odprawię mszę św. w intencji najrychlejszego uzdrowienia Waszej Eminencji, prosząc Boga, by nam Waszą Eminencję najdłużej utrzymywał i zachował.

Całując pierścień Waszej Eminencji łączę wyrazy najgłębszej czci, zawsze bardzo oddany

+ Teodorowicz

Lwów, dnia 11 kwietnia 1935

de und Volke Israel (Freiburg 1932), tłumaczenie polskie: Życie Jezusa na tle kraju i narodu izraelskiego, wedle 3 poprawionego wydania (Kraków 1936).

350 Brak podpisu.

351 Mszps pisany na 1 stronie formatu A4. Kopia listu przechowywana w FKiDOP, t. 130, sygn. 166/19 [6], s. 111.

${ }^{352}$ Chodzi o list pasterski ogłoszony 12 marca 1935 roku: Z życia Kościoła Chrystusowego. List pasterski Jego Eminencji Ks. Kardynała Prymasa, „MK”, 50, 1935, 4, s. 117-130.

${ }^{353}$ O ducha chrześcijańskiego w Polsce. List pasterski Episkopatu Polski, Płock [1934]. List ogłoszono 21 lutego 1934 roku, a jego autorem był kardynał Hlond. Por. list arcybiskupa J. Teodorowicza do kardynała A. Hlonda z 26 lutego 1934 roku w niniejszej edycji.

354 Łac.: argumenty dostosowane do danego człowieka. 
60.

ASIK, $A H$, t. V, cz. 10, s. 238-239, arcybp J. Teodorowicz do kard. A. Hlonda ${ }^{355}$.

\section{Wasza Eminencjo!}

Korzystam z dobrej okazji, ażeby przesłać Waszej Eminencji list nie obawiając się rewizji na poczcie. Zaczynam od wyrażenia radości i wdzięczności Bogu za uzdrowienie Waszej Eminencji, które jest jednak i momentami nakazującym większe szanowanie się na przyszłość.

Dziękuję osobno za tak szczęśliwe ujęcie telegramu po śmierci Piłsudskiego ${ }^{356}$. Jakkolwiek jego udział w bitwie pod Warszawą wyglądał inaczej od urzędowych sprawozdań ${ }^{357}$, mimo to wygrana pod Warszawą okrywała chwałą głównego dowodzącego wodza, a była ostatnim ratunkiem chrześcijaństwa. Jaka szkoda, że dwaj biskupi Gawlina i Kubina, nie umieli się odnieść do idei chrześcijańskiej i poniżyli ambonę do bałwochwalczych kadzideł obcego wierze i niepojednanego z Bogiem człowieka ${ }^{358}$. Bo Pił[sudski] się nie spowiadał jak mi to mówił biskup Gall ${ }^{359}$ na podstawie protokolarnego sprawozdania. Był już nieprzytomny gdy ksiądz przybył ${ }^{360}$, a dzień przedtem Piłsudska ${ }^{361}$ nie chciała się zgodzić na przyjęcie księdza pod pozorem, że to jej męża wzruszyć może. Kościół za te kadzidła pochlebców kiedyś gorzko zapłaci. Ludzie milczą, bo milczeć muszą, ale kiedyś przyjdzie czas, iż się odezwą.

Podobno telegram Waszej Eminencji do Rydza-Śmigłego ${ }^{362}$ miał zrobić na nim duże wrażenie. Sam Śmigły jest radykałem i lewicowcem, ale w gruncie

${ }^{355}$ Mszps pisany na 2 stronach formatu A4. List o tej samej treści z datą 17 czerwca 1935 roku znajduje się w: ASIK, $A H$, t. V, cz. 28, s. 185-186.

356 Józef Piłsudski zmarł 12 maja 1935 roku.

357 Aluzja do informacji o rezygnacji Piłsudskiego z funkcji naczelnego wodza, złożonej na ręce premiera Wincentego Witosa, i opuszczeniu Warszawy w czasie bitwy warszawskiej z wojskami sowieckimi w sierpniu 1920 roku, co podważa legendę Piłsudskiego.

${ }^{358}$ Według niektórych źródeł Piłsudski powrócił do Kościoła katolickiego podczas pierwszej wojny światowej. Szerzej zob. A. Garlicki, Józef Pitsudski 1867-1935, Kraków 2017, s. 103.

359 Stanisław Gall (1865-1942) - święcenia kapłańskie otrzymał w 1887 roku w Warszawie, biskup pomocniczy archidiecezji warszawskiej (1918-1919, 1933-1940), biskup polowy Wojska Polskiego (1919-1933), administrator apostolski archidiecezji warszawskiej (19401942), generał dywizji Wojska Polskiego. K. Krasowski, Biskupi katoliccy II Rzeczypospolitej, s. 67-69.

${ }^{360}$ Umierającemu Piłsudskiemu sakramentu ostatniego namaszczenia i absolucji udzielił ks. Władysław Korniłowicz, który przekazał te informacje w liście do arcybiskupa A. Sapiehy. P. Kajzar, Mauzoleum marszałka Józefa Pitsudskiego na Wawelu w latach 1935-1989, Kraków 2018, s. 21.

${ }^{361}$ Chodzi o drugą żonę Piłsudskiego, Aleksandrę Szczerbińską Piłsudską (1882-1963).

362 Edward Śmigły-Rydz (1886-1941) - członek Związku Strzeleckiego, w czasie pierwszej wojny światowej służył w Legionach, od 1935 roku generalny inspektor Sił Zbrojnych, 
rzeczy porządnym człowiekiem. Niestety, wojskowo zdolny, ma być zupełnie nieorientującym się analfabetą $\mathrm{w}$ rzeczach politycznych. Przewidują, że między nim a Sosnkowskim ${ }^{363}$ dojdzie do rozgraniczenia władzy: i Rydz weźmie wojsko ${ }^{364}$, zaś Sosnkowski obejmie dział polityczny zrazu jako minister spraw wojskowych, [a] później premier. Czy będzie prezydentem tego dziś powiedzieć nie można. Klika będzie forsować z łatwo zrozumiałych względów prezydenta obecnego $^{365}$. On sam pod wpływem młodej żony ${ }^{366}$ kurczowo trzyma się władzy i chce prezydentem pozostać. Rydz i Sosnkowski są przeciwni Beckowi ${ }^{367}$ i jego polityce. Obecny premier Sławek ${ }^{368}$ zażądał od Beka porozumienia w polityce spr[aw] zagranicznych, a gdy Bek ${ }^{369}$ oponował tłumacząc, że prowadzić będzie politykę samodzielnie, sprawa oparła się o prezydenta, który przyznał słuszność Sławkowi. Bek ${ }^{370}$ miał się podać do dymisji, ale odroczono decyzję do jesieni.

W ogóle sytuacja w tym się szczególniej uwydatnia, że nie ma ani jednego człowieka w obozie Piłsuds[kiego], który by do sytuacji dorastał. Ci ludzie przyzwyczajeni do tego, że w każdej sprawie rozkaz z Belwederu rozstrzygał o wszystkim, pozostawieni sami sobie stają zupełnie bezradni, w tym są tylko zgodni, że terrorem zechcą podtrzymać swój prestige ${ }^{371}$.

w czasie kampanii wrześniowej 1939 roku naczelny wódz, w 1940 roku założył na Węgrzech organizację konspiracyjną Obóz Polski Walczącej; w 1941 roku wrócił potajemnie do Polski, gdzie zmarł nagle w Warszawie. G. Mazur, Śmigły-Rydz Edward, w: Kto byt kim, s. 143-144.

${ }^{363}$ Kazimierz Sosnkowski (1885-1969) - działał w Polskiej Partii Socjalistycznej, Organizacji Bojowej PPS, Związku Walki Czynnej, Związku Strzeleckim; w czasie pierwszej wojny światowej szef sztabu, następnie dowódca I Brygady Legionów, minister spraw wojskowych (1920-1924); w czasie kampanii wrześniowej 1939 roku dowódca Frontu Południowego, zastępca prezydenta Władysława Raczkiewicza, pełnił różne funkcje w rządzie emigracyjnym, naczelny wódz (1943-1944). W 1944 roku osiadł na stałe w Kanadzie. G. Mazur, Sosnkowski Kazimierz, w: Kto byt kim, s. 142.

${ }^{364}$ W oryginale „wszystko”.

365 Chodzi o Ignacego Mościckiego (1867-1946), prezydenta RP w latach 1926-1939.

366 Maria Mościcka z domu Dobrzańska (1896-1979) - druga żona Ignacego Mościckiego.

367 Józef Beck (1894-1944) - służył w Legionach oraz w Polskiej Organizacji Wojskowej, potem attaché wojskowy w Paryżu i Brukseli (1922-1923), szef gabinetu ministra spraw wojskowych (1926-1930), minister spraw zagranicznych (1932-1939), senator RP (19351939); zmarł podczas internowania w Rumunii. J. Łapto s, A. Mania, Beck Józef, w: Kto byt kim, s. 90 .

${ }^{368}$ Walery Sławek (1879-1939) - należał do Polskiej Partii Socjalistycznej, w czasie pierwszej wojny światowej służył w I Brygadzie Legionów; po odzyskaniu przez Polskę niepodległości był zaufanym współpracownikiem Józefa Piłsudskiego, prezesem Związku Legionistów (1924-1936), prezesem BBWR (1928-1935), posłem na sejm (1928-1938), premierem RP (1930-1931, 1935). J. Gołębiowski, Stawek Walery „, Gustaw”, w: Kto byt kim, s. 67.

369 Pisownia zgodna z oryginałem.

$370 \mathrm{JW}$.

${ }^{371}$ Fr.: prestiż. 
Lewica się organizuje i na to należy mieć baczne oko i [s]kupić siły katolickie. Zdaje się, że Rydz przeznaczony na naczelnego wodza w czasie wojny nie będzie szedł na żaden radykalny program wobec Kościoła, mając zbyt wiele troski i odpowiedzialności własnej. Jakie cele ma radykalna organizacja żywiołów lewicowych w B[ezpartyjnym] B[loku] i poza B[ezpartyjnym] B[lokiem] trudno jest jeszcze orzec.

Tyle na razie informacji przesyłam Waszej Eminencji i namawiam bardzo po Jugosławii na Krynicę.

Całując pierścień Waszej Eminencji i łącząc najoddańsze wyrazy czci najgłębszej

+ Teodorowicz Krynica, 11/VI [1]935

61.

ASIK, $A H$, t. V, cz. 10, s. 240, kard. A. Hlond do arcybpa J. Teodorowicza ${ }^{372}$.

Poznań, 19.6.1935

Ekscelencjo!

Dziękuję najserdeczniej W[aszej] E[kscelencji] za łaskawe pismo z $11 \mathrm{bm}$. i za przesłanie mi wiadomości.

Cieszę się bardzo, że Ekscelencja odbywa swą kurację w Krynicy. Po powrocie z Jugosławii najchętniej podążyłbym tamże, ale zdaje się, że czeka mnie tą razą inna kuracja, dostosowania do potrzeb organizmu po tegorocznej chorobie. Mimo niemal miesięcznej rekonwalescencji nie zdobyłem jeszcze poczucia dawnych sił, chociaż choroba zasadniczo jest wyleczona. Temu trzeba będzie jednak gwałtownie zaradzić.

Łączę życzenia najpomyślniejszej kuracji i z czcią najgłębszą jestem W[aszej] $\mathrm{E}$ [kscelencji] powolny sługa i brat w Chr[ystusie]

August Kard. Hlond

${ }^{372}$ Mszps pisany na 1 stronie formatu A4. List tej samej treści zamieszczono w: ASIK, $A H$, t. IV, cz. 21 , s. 90 . 
62.

FKiDOP, t. 136, sygn. 93/19 [6], s. 29-30, arcybp J. Teodorowicz do kard. A. Hlonda ${ }^{373}$.

Wasza Eminencjo!

Bardzo dziękuję Waszej Eminencji za list ostatni. Niech sobie Wasza Eminencja o swoich jubileuszach myśli co chce, ale ci co kochają Waszą Eminencję będą zawsze głosowali za jubileuszami częstymi.

Ja niestety w Krynicy nie byłem skutkiem zdrowia, lecz skutkiem choroby spowodowanej przeciążeniem pracy umysłowej. Po sześciotygodniowym wypoczynku na wsi przyszedłem zupełnie do siebie.

Posyłam Waszej Eminencji przez ks. Bogdanowicza odpis listu Kapituły do nuncjusza, ażeby Waszej Eminencji przedstawić co nam grozi wskutek jakiegoś jakby zaślepienia sfer decydujących. Za kilka dni prześlę Waszej Eminencji odpis mojego listu do nuncjusza, który obecnie układam: sfałszowanie dokumentu jest czymś niepojętym, a w następstwach swoich groźnym ${ }^{374}$.

Łączę dla Waszej Eminencji najoddańsze wyrazy czci całując pierścień, sługa w Chrystusie 375

Lwów, dnia 26 października 1935

63.

FKiDOP, t. 136, sygn. 134/19 [6], s. 31, arcybp J. Teodorowicz do kard. A. Hlonda ${ }^{376}$.

Wasza Eminencjo!

Dziękuję najuprzejmiej za list i najchętniej przystąpię do komitetu, na czele którego stanie Wasza Eminencja. Uważam też za bardzo szczęśliwą myśl Waszej Eminencji, ażeby w darze jubileuszowym złożyć J[ego] Eminencji ${ }^{377}$ medal $^{378}$;

373 Mszps pisany na 2 stronach formatu A4.

${ }^{374}$ W korespondencji duchowieństwa ormiańskiego poruszano kwestię rzekomego spisku niektórych kanoników kapituły ormiańskiej we Lwowie, którzy podczas choroby arcybiskupa Teodorowicza mieli podejmować starania w Stolicy Apostolskiej o wyznaczenie jego następcy. T. Krzyżowski, Kulisy nominacji następcy ormiańskokatolickiego arcybiskupa Lwowa Józefa Teodorowicza, „Lehahayer”, 5, 2018, s. 251.

375 Brak podpisu.

376 Mszps pisany na 1 stronie formatu A4.

377 Chodzi o jubileusz pięćdziesięciolecia kapłaństwa kardynała Aleksandra Kakowskiego przypadający na dzień 30 maja 1936 roku.

378 Jubileuszowy medal projektu Jana Wysockiego wybito w brązie; miał średnicę $55 \mathrm{~mm}$. $\mathrm{Na}$ awersie umieszczono podobiznę kardynała Kakowskiego, na rewersie herb hierarchy oraz okolicznościowy napis. Aleksander Kakowski posłaniec wolności. Zeszyt dokumentacyjny, oprac. W. Krzyżew ski, Warszawa 2017, s. 20. 
kielichów, monstrancji ma on już bez liku i taki dar byłby tylko małym przyczynkiem do tego, co posiada. Tymczasem medal wyróżni go i nada piętno indywidualne hołdowi złożonemu jego osobie.

Całuję pierścień Waszej Eminencji i łączę najoddańsze wyrazy czci głębokiej i szacunku ${ }^{379}$

Lwów, dnia 22 listopada 1935

64.

FKiDOP, t. 130, sygn. 74/19 [6], s. 112, arcybp J. Teodorowicz do kard. A. Hlonda ${ }^{380}$.

Wasza Eminencjo!

W odpowiedzi na list łaskawy z dnia 3 grudnia br. oświadczam, że zgadzam się na wszystkie zarządzenia i plany Waszej Eminencji w sprawie obchodu jubileuszu ks. kardynała ${ }^{381}$.

Łączę wyrazy mej czci najgłębszej i najoddańszej382

Lwów, dnia 7 grudnia $1935^{383}$

65.

FKiDOP, t. 130, sygn. 395/216 [6], s. 113, arcybp J. Teodorowicz do kard. A. Hlonda ${ }^{384}$.

Wasza Eminencjo!

Dziękuję bardzo Waszej Eminencji za łaskawie przysłane życzenia, które przede wszystkim jednak są bardzo potrzebne dla Waszej Eminencji, zwłaszcza gdy są poparte gorącą modlitwą o zdrowie Waszej Eminencji.

Dziękujemy Bogu, że w tym roku wyprowadził Waszą Eminencję z ciężkiej choroby, a w tym złym jest to jedno dobre, że jednak choroba ta była momentem nakładającym konieczne więzy na gorliwość Waszej Eminencji. Życiem tak wyczerpującym i spalającym dalej żyć nie można. Wasza Ekscelencja ${ }^{385}$ sam wie najlepiej, jak nie tylko potrzebnym, ale wprost - po ludzku mówiąc - niezbędnym jest dla kierowania naszego Kościoła.

379 Brak podpisu.

${ }^{380}$ Mszps pisany na 1 stronie papieru formatu A4.

381 Jubileuszu pięćdziesięciolecia święceń kapłańskich kardynała A. Kakowskiego. Zob. list arcybiskupa J. Teodorowicza do kardynała A. Hlonda z 22 listopada 1935 roku w niniejszej edycji.

382 Brak podpisu.

383 Pod datą: „Ks. Prymas”.

${ }^{384}$ Mszps pisany na 1 stronie papieru formatu A4.

385 Pisownia zgodna z oryginałem, winno być: Eminencja. 
Co do plataty, to jak już oświadczyłem w poprzednim liście ${ }^{386}$, zgadzam się na wszystko, a zwłaszcza na napis, który niby wiele mówi, a w istocie rzeczy nic nie mówi; w tym zaś jest i cała sztuka, i cała prawda.

Całując pierścień Waszej Eminencji, łączę najoddańsze wyrazy czci najgłębszej ${ }^{387}$

Lwów, dnia 20 grudnia $1935^{388}$

66.

FKiDOP, t. 130, sygn. 859/110 [5], s. 114, arcybp J. Teodorowicz do kard. A. Hlonda ${ }^{389}$.

Wasza Eminencjo!

Bardzo dziękuję Waszej Eminencji za łaskawie mi przysłany list pasterski ${ }^{390}$. Jest on naprawdę prześliczny, a przede wszystkim utrafia w najżywotniejsze problemy, jak w sprawę żydowską, jak w zepsucie dzisiejsze w sposób niezwykle silny, a szczególniej w sprawie żydowskiej niezwykle zręczny. Toteż zdaje mi się, że żydzi ${ }^{391}$ woleliby, by Wasza Eminencja nawoływał do bicia szyb w ich sklepach, aniżeli taką obronę w ataku, jaka im się w tym liście dostała w udziale.

Cieszę się zdrowiem Waszej Eminencji, które mimo usterek jednak służy, gdyż zaniepokoiłem się poprzednio wiadomością z gazet o leczeniu się Waszej Eminencji u Elżbietanek.

Korzystam ze sposobności, ażeby dołączyć Waszej Eminencji życzenia świąt najlepszych i całując pierścień Waszej Eminencji, zasyłam wyrazy mojej czci najgłębszej, zawsze oddany ${ }^{392}$

Lwów, dnia 7 kwietnia $1936^{393}$

\footnotetext{
386 Tj. w liście z 27 grudnia 1935 roku.

387 Brak podpisu.

388 Pod datą: „Ks[iądz] Prymas Hlond”.

389 Mszps pisany na 1 stronie papieru formatu A4.

390 List pasterski J[ego] Em[inencji] Ks. Kardynała Prymasa o katolickie zasady moralne, Poznań, 29 lutego 1936.

391 Pisownia zgodna z oryginałem.

392 Brak podpisu.

393 Pod datą: „Ks. Prymas Hlond”.
} 


\section{7.}

FKiDOP, t. 130, sygn. 800/110 [5], s. 115-116, arcybp J. Teodorowicz do kard. A. Hlonda ${ }^{394}$.

\section{Wasza Eminencjo!}

Prawdziwie zawstydził mnie Wasza Eminencja uprzedzając mnie swym listem z życzeniami, za które z serca dziękuję i Waszej Eminencji najgorętsze przesyłam. Pozwalam je sobie skierować ku Osobie Waszej Eminencji, prosząc na nowy i przyszły rok Ducha świętego, by wziął bardziej w więzy Waszą Eminencję, a przez to sprowadził ustatkowanie jeszcze większego zdrowia, na którym jak to dobrze Wasza Eminencja wie - tak nam wszystkim bardzo a bardzo zależy.

W tym roku wybija się w pracach Waszej Eminencji dokonanie tak szczęśliwie i chwalebne Synodu, a zaznaczył się ten rok działalnością Waszej Eminencji tak, że postać Jego i działalność nawet przez koła dotąd z dala stojące została tak szczególnie uwydatniona i odznaczona.

Do gorących moich życzeń pozwalam sobie dołączyć moją ostatnią pracę o Starym Testamencie ${ }^{395}$.

Polecając się modłom Waszej Eminencji całuję Jego pierścień i łączę najoddańsze wyrazy mojej czci głębokiej, sługa w Chrystusie ${ }^{396}$

Lwów, dnia 21 grudnia $1936^{397}$

68.

FKiDOP, t. 136, sygn. 721/110 [5], s. 8-9, arcybp J. Teodorowicz do kard. A. Hlonda ${ }^{398}$.

\section{Wasza Eminencjo!}

Jakkolwiek wiem, że molestuję Waszą Eminencję drobiazgami, to jednak nie mogę odmówić prośbie, którą przeze mnie skierowuje do Waszej Eminencji adwokat w Stryju ${ }^{399}$ niejaki dr S. Margulies ${ }^{400}$.

Pisał on w swej sprawie do Waszej Eminencji w dniu 7 I br., ale nie otrzymał odpowiedzi. Rodzina dr. Marguliesa znana mi jest jeszcze z Brzeżan ${ }^{401}$ i wte-

${ }^{394}$ Mszps pisany na 2 stronach papieru formatu A4

$395 \mathrm{Tj}$. drugi tom żywota Chrystusa pt. Od Jahwy do Mesjasza.

396 Brak podpisu.

397 Pod datą: „Ks. Prymas”.

398 Mszps pisany na 2 stronach formatu A4.

399 Stryj - miasto powiatowe w województwie stanisławowskim.

400 Salomon Margulies - adwokat, do 1939 roku mieszkał w Stryju przy ulicy Krasińskiego 4, dalsze losy nieznane; podczas okupacji niemieckiej jego córkę Renatę uratowały od zagłady ss. józefitki, z pomocą ks. Bogusława Waszczyńskiego, Edwarda Grzybowskiego i lokalnych struktur Armii Krajowej.

${ }^{401}$ Brzeżany - miasto powiatowe w województwie tarnopolskim. 
dy to on wraz ze swą matką, jakkolwiek żydówką ${ }^{402}$ uczęszczał na moje kazanie. Czuł się on chrześcijaninem, ale tylko ze względu na rodzinę nie złożył formalnego aktu wiary. Dziś przekroczywszy sześćdziesiątkę, chciałby jak mi to mówił, za wszelką cenę uporządkować sprawę swej wiary i przejść formalnie na łono Kościoła. Mówi mi jednak, że taki akt przejścia czyni jego dalsze pozostanie w Stryju jako adwokata, zresztą nawet u katolików wziętego, niemożliwym. Z tego powodu jego przejście na katolicyzm jest połączone $\mathrm{z}$ warunkiem otrzymania miejsca, o ile być może, jak najdalej od Stryja. Człowiek ten poważny, robiący jak najlepsze wrażenie, na moją uwagę czy by we Lwowie nie można się o takie miejsce postarać, odpowiedział mi, że Lwów jest zbyt blisko Stryja. Chciałby mieć takie miejsce w Poznaniu, a przyjąłby jakiekolwiek, jak mi mówił jakiego sędziego prowizorycznego czy w ogóle coś podobnego. Wiem, że jest to dzisiaj bardzo trudne, ale w każdym razie poczuwam się do obowiązku wobec tej duszy, ażeby sprawę jego przedstawić Waszej Eminencji.

Całując pierścień Waszej Eminencji, łączę przy tej sposobności najgłębsze wyrazy czci zawsze oddany ${ }^{403}$

Lwów, dnia 8 marca 1937

69.

FKiDOP, t. 54, sygn. 22/53 [8], s. 12-14, arcybp J. Teodorowicz do kard. A. Hlonda ${ }^{404}$.

Wasza Eminencjo,

Korzystając z tego, że Wasza Eminencja jedzie teraz do Rzymu, zwracam się do Waszej Eminencji z prośbą w mojej sprawie: załączam tu Waszej Eminencji odpis pisma z Kongregacji ${ }^{405}$, które wyjaśnia całą sytuację. Pismo to wprawdzie nie może się równać postawieniu mej książki na indeksie, ale w każdym razie jest pod pewnym względem jego wskazaniem.

Nie potrzeba wielu domysłów na to, ażeby wiedzieć skąd wyszła inicjatywa i jaki był bezpośredni i osobisty cel tych, którzy się przyczynili do tego kroku ze strony św. Officii ${ }^{406}$.

To jednak do rzeczy nie należy i staję przed tym aktem jak przed faktem dokonanym.

${ }^{402}$ Pisownia zgodna $z$ oryginałem.

403 Brak podpisu.

${ }^{404}$ Mszps pisany na 3 stronach papieru formatu A4.

${ }^{405}$ Zob. załącznik nr 1 do niniejszego listu.

406 Właściwie winno być: Sancti Officii - Święte Oficjum. 
Z mej strony zastosowałem się do rozporządzenia św. Oficjum ${ }^{407}$ : napisałem zaraz do księgarni wydawniczej Pusteta ${ }^{408}$, zaś na prośbę tłumaczenia tej książki na język francuski odpowiedziałem, że obecnie zgodzić się na to nie mogę. Także nie przedsięwziąłem żadnych kroków wobec oferty przedstawionej mi przez O. Garrigou-Lagrange OP, a poruszającej kwestię tłumaczenia [książki] na język angielski. Także przygotowaną pracę w sprawie wydania tej książki w języku polskim przerwałem. Rozpoczęta przeze mnie odpowiedź Doktorowi Deutschowi $^{409}$ wyjdzie nie pod moim nazwiskiem ${ }^{410}$.

Rzecz naturalna, bardzo musiało zależeć mi na tym, by się dowiedzieć jakie są powody tego kroku, co S[anc]t[um] Officium zarzuca mej książce, gdyż dowiedziawszy się o tym mógłbym pomyśleć o wydaniu nowej książki napisanej już wedle wskazówek udzielonych mi przez Sanctum Officium.

Nie chcąc zajmować Waszej Eminencji moją sprawą udałem się do Biskupa Franciszka Agagianiana ${ }^{411}$ ob[rządku] orm[iańskiego], a ten wystosował pismo do kongregacji, które tu w odpisie załączam ${ }^{412}$. Na to pismo nie otrzymał on jednak odpowiedzi.

Sposób ten postępowania Sancti Officii jest po prostu wobec katolickiego Biskupa czymś co trudno wytłumaczyć, bo jeśliby nawet ktoś próbował tłumaczyć ten krok Kongregacji podjęty bez odniesienia się do Biskupa i bez podania mu motywów tradycyjną normą postępowania, to znany Waszej Eminencji fakt z książką Karola Adama „O istocie katolicyzmu” ${ }^{13}$ jest już precedensem, który powinien być przede wszystkim zastosowany do katolickiego Biskupa.

Mam prawo więc dowiedzieć się o tym, dlaczego nastąpiło to zarządzenie, co zarzuca Kongregacja mej książce, a po precedensie z księdzem Adamem ma ona zadośćuczynić memu życzeniu i umożliwić mi wydanie tego dzieła z odpowiednimi zmianami.

407 Pismem z dnia 23 listopada1936 roku Kongregacja Świętego Oficjum zabroniła arcybiskupowi Teodorowiczowi jakichkolwiek thumaczeń książki pt. Konnersreuth im Lichte der Mystik und Psychologie (Salzburg 1936). Poleciła również wycofanie ze sprzedaży całego nakładu. Zob. załącznik nr 1 do niniejszego listu.

408 Verlag Anton Pustet - wydawnictwo z siedzibą w Salzburgu powstałe w 1862 roku. Arcybiskup Teodorowicz zwrócił się do wydawnictwa, aby wstrzymało sprzedaż książki.

409 Josef Deutsch - doktor medycyny, jeden z głównych przeciwników Teresy Neumann, autor artykułów podważających autentyczność jej stygmatów i objawień.

${ }^{410}$ Nie udało się ustalić, czy owa odpowiedź ukazała się drukiem.

411 Ghazaros (po pol.: Łazarz) Aghadżanian (1895-1971) - duchowny ormiańskokatolicki, rektor Papieskiego Kolegium Ormiańskiego w Rzymie (1932-1937), patriarcha Kościoła ormiańskokatolickiego jako Grzegorz Piotr XV (1937-1962), od 1946 roku kardynał. T. Krzyżows ki, Archidiecezja lwowska, s. 218.

412 Zob. załącznik nr 2 do niniejszego listu.

413 K. Adam, Das Wesen des Katholizismus, Augsburg 1924. 
Wobec tego nie pozostaje mi nic innego, jak udanie się w tej sprawie wprost do Ojca św. i dlatego proszę Waszą Eminencję, by zechciał w formie jaką uzna za najstosowniejszą najłaskawiej doręczyć Ojcu św. to moje pismo ${ }^{414}$. Jeśliby Wasza Eminencja uznał, że należy coś w tym piśmie opuścić lub zmienić i gdyby jeszcze czas był na to, to mógłbym to jeszcze uczynić. Prosiłbym w takim razie o wskazówki listem expres. Załączam tu dla Waszej Eminencji różne recenzje pism ${ }^{415}$, które myślałem dołączyć do mojej petycji do Ojca św.

Otóż to jest cel mojej prośby, którą składam w ręce Waszej Eminencji. Prośbę tę zaniosłem ze stanowiska osobistego, ale sądzę, że moralnie łączy się ona w ogóle ze stanowiskiem Episkopatu polskiego, zwłaszcza wobec napadu Dr. Deutscha na obcych, nie niemieckich, cudzoziemskich Biskupów. Zresztą Wasza Eminencja sam to najlepiej zrozumie, tak że nie potrzebuję na ten temat nic więcej pisać.

Pozostaje mi jeszcze przejść wszelkie możliwości właściwych pobudek tych zarządzeń wobec mojej książki. Uczynię to na osobnym arkuszu ${ }^{416}$.

Składam tedy sprawę tę $\mathrm{z}$ całą ufnością w ręce Waszej Eminencji w tej nadziei, że sam uczyni te kroki, które w danych warunkach uzna za najlepsze i najskuteczniejsze.

Nie potrzebuję Waszej Eminencji pisać, jaki to dla mnie cios moralny, już nie ze względu na kilka lat jakie włożyłem w tę pracę, ale na prestige mych prac naukowych w ogóle, które, o ile Bóg mi da siły i zdrowie, chciałbym skończyć. Uderzenie w jedno dzieło jest uderzeniem we wszystkie, jeśli nie bezpośrednim to pośrednim.

Całuję pierścień Waszej Eminencji, a modląc się gorąco za Waszą Eminencję, załączam wyrazy mej czci głębokiej, zawsze oddany

Może być, że znajdę czas, by Waszej Eminencji napisać w sprawie okólnika Ministra Oświaty, który otrzymałem, jak go otrzymali zapewne wszyscy księża Biskupi.

Lwów, dnia 27 III 1937 r.

[Załącznik nr 1 - odpis dekretu Kongregacji Świętego Oficjum] ${ }^{417}$

Suprema Sacra Congregatioex aedibus S. Officii die 23 XI [19]36

Sancti Officii

Num. prot. $761 / 27$

(in responsione fiat mentio hujus numeri)

414 Zob. załącznik nr 3 do niniejszego listu.

415 Załączniki nie zachowały się.

416 Zob. załącznik nr 4 do niniejszego listu.

417 Mszps pisany na 1 stronie formatu A4. FKiDOP, t. 54, sygn. 22/53 [8], s. 2. 


\section{Excellentia Revma,}

Suprema haec S. Congregatio in conventu plenario habito feria IV, II novembris 1936, decrevit quae sequuntur relate ad librum ab E.T. Revma aditum, cui titulus: "Konnersreuth im Lichte der Mystik und Psychologie".

"Libri supradicti impediendas esse versiones et novas impressiones; retrahenda pro posse exemplaria a mercatura libraria; ipse autem auctor se abstineat a quacumque supra hoc argumento activitate".

Quae dum Tecum communico ad executionem mandanda, impensam meam observantiam Tibi obtestor ac permaneo E.T. Revmae add. mus

+ D. Card. Sbarretti ${ }^{418}$ Episcopus Sabiniensis et Mandebusis Secretarius

Exmo ac Revmo

Dom. Josepho Teodorowicz Archiepiscopo Leopoliensi Armenorum

[Załącznik nr 2 - odpis pisma bpa Franciszka Agagianiana do Kongregacji Świętego Oficjum] $]^{419}$
A Sua Eminenza Reverendissima
Il. Sig. Card. Donato Sbarretti
Vescovo di Sabina e Poggio Mirteto,
Segretario della Suprema S. Congr. del St. Offizio

\section{Eminenza Reverendissima,}

Mons. Teodorowicz, Arcivescovo Armeno di Leopoli mi partecipa di aver ricevuto un venerato ufficio di cotesta Suprema con cui gli è stata comunicata la decisione della Congregazione plenaria dell'll Novembre 1936 circa il libro da lui edito dal titolo: Konnersreuth im Lichte der Mystik und Psychologie - per cui vengono proibite le traduzioni e le ristampe del suddetto libro, gli si impone di ritrarre le copie per quanto possibile, dal commercio e di astenersi da qualunque attività circa il detto argomento.

Mons. Teodorowicz dopo aver detto: "Je me déclare prêt, afin de ne pas perdre le fruit de tant de travail, de refaire à nouveau le livre entier selon les indications reçues de la St. Congrégation. Je prie V.E. de vouloir m'indiquer la voie, qu'il faudrait choisir afin d'obtenir de la part des sphères interessées des indications touchant à la réédition de mon livre, à savoir ce qu'il faudrait y éviter ou changer. Appuyé sur ces informations préliminaires, je pourrais envoyer à Rome l'un de

418 Donato Raffaele Sbarretti (1856-1939) - święcenia kapłańskie otrzymał w 1879 roku, wykładowca w Atheneum Papieskim Propagandy Fide, urzędnik dykasterii watykańskich, sekretarz Kongregacji Świętego Oficjum (1930-1939).

419 Mszps pisany na 1 stronie formatu A4. FKiDOP, t. 138, sygn. 457/190 [7], s. 2. 
mes chanoines très bien versé dans mon livre, ayant des connaissances justes et claires sur son idée maitre. Je désirerais qu'il puisse sur place discuter les points en question et préparer une nouvelle édition du livre. Votre Excellence aura l'extrême bonté de me faire savoir si mon projet est réalisable".

Nel sottomettere quanto sopra alla benevola considerazione di Vostra Eminenza, resto in umile attesa delle sue venerate comunicazioni.

Chinato al bacio della Porpora con sensi di profonda venerazione, ho l'onore di professarmi, di Vostra Eminenza Roma

F. Agagianian

18 Gennaio 1937

[Załącznik nr 3 - odpis pisma arcybpa J. Teodorowicza do Piusa XI] $]^{420}$

Très Saint Père, L'Archevêque de Lwów soussigné, humblement prosterné aux pieds de Votre Sainteté vient Lui présenter une prière dans la question que voici: J'ai publié l'année dernière un livre allemand intitulé "Konnersreuth im Lichte der Mystik und Psychologie".

Le but principal de cet ouvrage n'était pas autant l'interprétation des phénomènes qui se produisirent à Konnersreuth, que plutôt la mise en lumière des questions mystiques en général avec l'égard spécial à l'insuffisance des méthodes employées jusqu'ici pour expliquer ces phénomènes.

Le fait de Konnersreuth même n'y intervient donc qu'en qualité d'exemple caractéristique et expérimental, propre à expliquer certains de ces phénomènes. Aussi après l'avoir longuement examiné j'allais déposer le fruit de mes expériences dans ce livre, tenant d'autre part amplement compte du vaste mouvement mystique se manifestant de nos jours.

Mon ouvrage présente donc un ensemble renfermant d'un côté le résultat d'un travail sérieux voué à la question de Konnersreuth m'ayant absorbé pendant plusieurs années d'autre part il constitue pour ainsi dire l'oeuvre de ma vie en tant qu'il visait à l'élucidation des problèmes mystiques auxquels j'avais consacré une grande partie de mon labeur.

Le premier, qui m'avait amené à aborder ce sujet dans un livre à part fut comme je l'avais d'ailleurs souligné dans l'avant-propos de mon auvrage - le R.P. Alois Mager O.S.B. Professeur à la faculté de théologie de Salzbourg.

En effet la question de Konnersreuth ne fut examinée jusqu'à l'heure que par des médecins, qui hélas souvent sont enclins d'affirmer péremptoirement, que tout ce qui appartient à la vie mystique n'est que pathologie s'apparentant à l'hystérie, la psychasthénie, le somnambulisme etc. Le profit positif de leurs efforts fut

${ }^{420}$ Mszps pisany na 4 stronach formatu A4. FKiDOP, t. 54, sygn. 22/53 [8], s. 18-21. 
donc presque nul. Les critères mystiques, qui à mon avis seuls sont capables de résoudre le problème, y furent totalement méconnus.

Telle fut une publication issue de la plume d'un médecin allemand M. le Dr Deutsch, parue en 1932.

Mais voici que soudain un coup inattendu et extrêmement douloureux vint s'effondre sur moi. Je reçois de la part du St. Office un décret dont je joins une copie sous ce pli, qui m'ordonne de faire disparaître, s'il se peut, mon livre du commerce libraire et de ne plus m'en occuper ainsi que des traductions, qui pour le moment restent interdites.

Aussitôt après l'avoir reçu je m'adressais à Rome. Profitant des services bienveillants de S.E. l'Evêque Fr. Agagianian du rite arm., je fis part au St. Office de ma soumission entière et sans restriction aucune à tous ses ordres, ne demandant qu'une faveur, c'est qu'on m'informât sur les causes immédiates d'une sentence si pénible et si inopinée, afin que je puisse entreprendre une correction des textes avec possibilité de rééditer l'ouvrage, comme dans le cas de Charles Adam, auteur célèbre allemand et son livre sur "L'essence du catholicisme" qui en constitue un précédent de récente mémoire.

La teneur du décret susméntionné m'expose en outre aux attaques de certains auteurs laïques rationalisants, tel le Dr Deutsch susmentionné, qui après avoir attaqué, il y a plusieurs années les phénomènes, de Konnersreuth, a publié récemment contre moi une lettre ouverte (parue comme manuscrite). Il faussa complètement mes textes, ainsi que mon attitude en face du problème. Un des évêques allemands désigna cette lettre du nom de "pamphlet incivil" ("ein ungezogenes Pamphlet").

Le décret susmentionné, tout en m'imposant le silence, m'ôte la possibilité de me défendre. Ce silence cependant pourrait être injurieux pas autant à ma personne qu'à la dignité épiscopale elle-même et préjudicieux non seulement au cas de Konnersreuth, mais encore à l'opinion saine que portent sur l'ensemble de ces phénomènes les catholiques des pays allemands.

D'autre part les critiques multiples et favorables qui affluent chaque jour de la part des catholiques, même adversaires et des non-catholiques, me sont une preuve de l'actualité de mon ouvrage.

En face de la phalange des auteurs, même catholiques, qui se laissent entraîner hors mesure par l'empire des méthodes expérimentales, prônées par des psychologues indépendants, il semble qu'une analyse foncière de la question, basée sur les critères de la théologie mystique était fort à temps, car si les phénomènes de Konnersreuth, comme tout l'indique, sont vrais, le signe d'en haut exige, surtout par le temps qui court, d'être mis à la portée de tous.

Daignez donc, Très Saint Père, en cette année, qui est le cinquantenaire de mon sacerdoce, exaucer mon humble prière et me faire signifier par le St Office quelles sont les objections à la diffusion de mon livre tout en me facilitant une réédition de mon ouvrage, remanié selon les indications reçues. 
En déposant aux pieds de Votre Sainteté avec une grande confiance ma prière susmentionnée, j’implore la Bénédiction Apostolique.

Et que Dieu...

J. Teodorowicz

Lwów, le 27 III 1937

P.S. Votre Saiteté voudra bien m'excuser de faire encore mention d'un fait presque analogue au mien qui se passa avec l'Évêque hongrois de sainte mémoire Monseigneur Prohaszka. Je n'ai nullement l'intention de me comparer à lui en ce qui concerne ses talents, sa vie apostolique et sainte, mais je viens de lire dans ses mémoires, qu'il avait passé par un creuset de souffrance et d'épreuves pareilles aux miennes et n'avait pu s'en relever jusqu'à la fin de sa vie, qu'il avait menée et terminée en vrai saint. Il écrit qu'après avoir reçu le décret du St Office, il se rendit aussitôt auprès de Pie $\mathrm{X}$, pour le supplier qu'on évite, même en cas où l'on ne pourrait lui rendre justice, d'émettre de pareils actes, au moins pour les temps à venir, contre des Évêques sans s'être entendu avec eux et sans leur en avoir donné la moindre explication. Et il ajoute que le St Père lui rendit parfaitement raison.

Je ne désire nullement en tirer des conséquences ou analogies pour mon cas, mais je veux avouer simplement, que la lecture de ce passage m'avait inspiré le désir de m'adresser directement au Vicaire du Christ pour chercher auprès de lui aide et soutien, Tout ce que Votre Sainteté ordonnera, je déclare d'avance l'accepter avec soumission entière et filiale.

Non seulement par égard au cinquantenaire de mon sacerdoce, qui par ce coup imprévu et soudain se voit troublé et voilé de tristesse, mais surtout par égard à mes autres travaux touchant à la vie de Notre Seigneur, j'ose supplier Votre Sainteté de vouloir m'accorder la grâce susmentionnée.

Il ne s'agit plus ici de ma personne. J'ai accepté cette lourde croix de la main du Tout-Puissant. Qu'il daigne m'aider à la porter aussi longtemps que bon lui semble. Ce coup cependant, en frappant l'un de mes travaux, les atteint tous et je suis à présent en train de les achever désirant les voir menés à bon terme. Ma prière donc, tout en étant personnelle, vise à un but impersonnel et m'est en vue de la gloire de Dieu bien à coeur.

[Załącznik nr 4 - Przypuszczalne motywy zarządzeń św. Oficjum] ${ }^{421}$

1) Powodem najbliższym i najbezpośredniejszym byłyby uchybienia czy błędy przeciw doktrynie katolickiej ze stanowiska teologii, czy też mistyki, czy w ogóle innych nauk.

${ }^{421}$ Mszps pisany na 3 stronach formatu A4. FKiDOP, t. 54, sygn. 22/53 [8], s. 15-17. 
a) Ze stanowiska teologii i mistyki: Posiadam ocenę O. Garrigou-Lagrange, który dał tę książkę do przestudiowania dwóm znanym teologom zakonu swego i wydał o niej orzeczenie dodatnie. Jeden właśnie z tych teologów podał projekt tłumaczenia tej książki na język angielski.

Drugie orzeczenie wydał znany profesor teologii na Uniwersytecie Fryburskim O. B[enoit] Lavaud $\mathrm{OP}^{422}$.

Nawet O. Mager ${ }^{423}$ mimo całej swej chwiejności wobec Konnersreuth podnosi szczególnie wartość mej książki ${ }^{424}$. A ze stanowiska (nawiasem mówiąc) błędnego, przekreślonego przez pracę Poulain'a ${ }^{425}$ pragnąłby tylko, i to ewentualnie, większego pogłębienia w sprawie stanów mistycznych Teresy Neumann. Ponieważ skłonny jestem sądzić siebie raczej ostrzej aniżeli mnie sądzą inni, wyrażam w końcu przypuszczenie, iż może teoria poznawalności cudu, aczkolwiek nie błędna, jednak [za] mało jest wyjaśniona.

b) Co do innych gałęzi nauk to nasuwałaby się przede wszystkim kwestia medycyny.

Lecz jak to wyrażają jednomyślnie recenzje Dr. Hynka ${ }^{426}$ z Pragi, Prof. Krau$\mathrm{sa}^{427} \mathrm{i}$ innych, ja właśnie usunąłem się od wszelkich sporów i orzeczeń w dziedzinie medycyny, oświadczając wyraźnie, że kwestii tych nie tykam się jako laik i pozostawiam je jedynie ocenie lekarzy. Sprawa ta zresztą jest przeze mnie tak jasno postawiona, że Dr Deutsch tykając jej był zmuszony uciec się do sfałszowania moich zasadniczych tekstów. Zresztą kwestia medycyny gra w książce mojej rolę zupełnie podrzędną, gdyż cały nacisk położony jest na stronę teologii mistycznej.

c) Kwestię zestawienia objawów mediumistycznych i okultystycznych ze stanami ekstaz omawiałem $\mathrm{z}$ najwytrawniejszym, może jedynym [s]pośród

${ }^{422}$ Benoit Lavaud (1890-1979) - dominikanin, profesor teologii na Uniwersytecie we Fryburgu Szwajcarskim, autor artykułu na temat Teresy Neumann: Les phénomènes extatiques et leurs dérivés chez Thérèse Neumann, „Études carmélitaines. Mystiques et missionaires” (dalej: „ÉC”), 1933, 1, s. 39-51.

${ }_{423}$ Alois Mager (1883-1946) - benedyktyn, święcenia kapłańskie otrzymał w 1909 roku, austriacki filozof i psycholog, od 1924 roku wykładowca filozofii chrześcijańskiej, psychologii eksperymentalnej i mistyki na Wydziale Teologicznym w Salzburgu; autor cenionych prac z dziedziny mistyki. Mager Alois, w: DBE, 6, München 1997, s. 561.

${ }^{424}$ A. Mager, Le Problemè scientifique de la Stigmatisation, „ÉC”, 1936, 2, s. 143-156.

${ }^{425}$ Auguste François Poulain (1836-1919) - jezuita, zajmujący się badaniem stanów mistycznych, autor wielokrotnie wznawianej pracy Des grâces d'oraison; traité de théologie mystique (Paris 1901).

426 Rudolf Maria Hynek (1883-1952) - czeski lekarz, autor publikacji o całunie turyńskim oraz o Teresie Neumann.

427 Trudno obecnie sprecyzować, o kogo dokładnie chodzi, gdyż w literaturze występuje wiele osób o takim nazwisku. Niewykluczone, że jest to późniejszy tłumacz książki arcybiskupa Teodorowicza na język angielski Rudolph Kraus. Mystical Phenomena in the Life of Threresa Neumann, by Most Reverend Josef Teodorowicz Archbischop of Lemberg translated by Rev. Rudolph Kraus, Ph.D., S.T.D., London 1940. 
niemieckich uczonych znawcą tych spraw, z P. Geheimrat ${ }^{428}$ Ludwigiem $^{429}$. Recenzję [jego] mej książki w końcowym ustępie dołączam do recenzji innych ${ }^{430}$. Dr Ludwig oddaje mi świadectwo, że w tych kwestiach książka moja jest bez zarzutu.

d) Jeśli chodzi o kwestię analogii między histerią a ekstazą, omawiałem ją szeroko we Wiedniu ze znanym pisarzem niemieckim, profesorem Uniwersytetu Wiedeńskiego i specjalistą właśnie w tym dziale Dr. Allersem ${ }^{431}$. W głównej i zasadniczej części mej książki, tam gdzie chodzi o stany pamięci Teresy Neumann podczas ekstazy, powołałem się na zdanie Prof. Allersa wypowiedziane w rozmowie ze mną. I znów Dr Deutsch musiał sfałszować tezę tę, by móc uderzyć na nią w swym liście otwartym (drukowanym jako manuskrypt).

e) Przedstawienie faktów z życia mistycznego Teresy Neumann oparte jest przede wszystkim na ścisłej bardzo własnej mej obserwacji. Oczywiście musiałem też uwzględnić i informacje osób postronnych i tu niezawodnie mógł się zakraść jeden czy drugi błąd informacyjny spowodowany może nie dość ścisłymi danymi tego, na którego zdaniu się oparłem. Ale i tu proboszcz z Konnersreuth Naber ${ }^{432}$ obiecał mi rewizję najściślejszą tych właśnie tekstów i o ile by zaszła potrzeba skorygowania ich. To są jednak już rzeczy drobne i nie znaczące.

2) Mógłby mi być uczyniony zarzut, który mi właśnie czyni Dr Deutsch, jakobym w sprawie Konnersreuth utrudniał [działanie] Biskupowi z Regensburgu ${ }^{433}$, który ojcu Teresy Neumann wyraził życzenie, by ten poddał córkę swą powtórnemu badaniu.

Tu Dr Deutsch próbuje mówić, jakobym pierwszą obserwację uważał za wystarczającą, a drugą za zbędną i w ten sposób działał przeciw stanowisku episkopatu niemieckiego. Na to odpowiadam:

a) Przede wszystkim to wszystko co napisałem o Teresie Neumann, głównie rysy jej duszy, charakter ogólny jej ekstaz, jest tylko dalszym rozwojem tych myśli, jakie Biskup Buchberger i Kard. Faulhaber ${ }^{434}$ wypowiedzieli o niej w swych

${ }^{428}$ Niem.: radca państwowy.

${ }^{429}$ August Friedrich Ludwig - teolog katolicki z uniwersytetu we Fryzyndze (Bawaria), autor między innymi Okkultismus und Spiritismus im Lichte der Wissenschaften und des katholischen Glaubens (München 1921) oraz Geschichte der okkultistischen Forschung von der Antike bis zur Gegenwart.

430 Załącznik nie zachował się.

431 Rudolpf Allers (1883-1963) - austriacko-amerykański psychiatra, psycholog i filozof; zajmował się między innymi filozoficznymi podstawami medycyny i psychologii medycznej, profesor w Instytucie Fizjologii w Wiedniu (1918-1938), w 1938 roku wyemigrował do Stanów Zjednoczonych, gdzie prowadził wykłady z filozofii i psychologii w Catholic University of America w Waszyngtonie i Georgetown University tamże. Allers Rudolpf, w: DBE, 1, München 1995, s. 91.

${ }^{432}$ Joseph Naber - proboszcz parafii pw. św. Wawrzyńca w Konnersreuth.

$433 \mathrm{Tj}$. biskupa Buchbergera $\mathrm{z}$ Ratyzbony.

${ }^{434}$ Michael von Faulhaber (1869-1952) - święcenia kapłańskie otrzymał w 1892 roku w Würzburgu, profesor Starego Testamentu na Uniwersytecie w Strasburgu, arcybiskup me- 
kazaniach. Pod tym względem jest moje stanowisko w zupełnej zgodzie ze stanowiskiem Episkopatu niemieckiego.

b) Co do powtórnej obserwacji zająłem stanowisko bardzo wyraźne w mej książce, usprawiedliwiając stanowisko Biskupów niemieckich, a nadto sam poczyniłem kroki, ażeby przez wpływ na ojca Teresy umożliwić zrealizowanie się życzeń Biskupów niemieckich. Odpowiednie ustępy z mej książki załączam W odpisie ${ }^{435}$.

3) Wzgląd na stan umysłów w Niemczech.

a) Gdybym ja był pierwszym z Biskupów, którzy pisali o Konnersreuth, mogłaby powstać kwestia, czy występowanie Biskupów w tej sprawie jest wskazane. Ale gdy moja praca powstaje po szeregu wypowiedzeń się czy wystąpień innych Biskupów, to wszelki podobny argument traci na sile.

Moja praca następuje po pracy Biskupa Salzburskiego Waitza ${ }^{436}$ i Kardynała praskiego Kaspara ${ }^{437}$ po kazaniu Biskupa Buchbergera (czerwiec 1929) i Kardynała Faulhabera (listopad 1927), a wreszcie po artykule o Konnersreuth Biskupa Buchbergera w „Lexikon für Theologie und Kirche” (1935) ${ }^{438}$.

b) Przypuszczenie jakoby książka moja nie była na czasie wobec rozdrażnienia umysłów spowodowanego odmiennością poglądów na Konnersreuth, upada zupełnie wobec odniesienia się do tej sprawy dwóch najpoważniejszych kierowników opinii przeciwnej O. Magera i Ks. Prof. Wunderlego ${ }^{439}$. Mager pisze o mej książce, że jest „obiektywną” i oddaje jej pochwały. Wunderle dziękuje mi w liście prywatnym za moje stanowisko w odniesieniu do niego i innych krytyków.

c) W ten sposób książka moja w gruncie rzeczy przyczynia się raczej do uspokojenia umysłów. List otwarty Deutscha jest tu bez znaczenia, nie posiada żadnej naukowej wartości, jest jednym szeregiem sfałszowanych tekstów mej książki i wydarzeń [w] Konnersreuth. Jeden z Biskupów niemieckich nazwał ten jego list otwarty „Ein ungezogenes Pamphlet ${ }^{440 ”}$. Zresztą Dr Deutsch człowiek niezmiernej osobistej ambicji nie po raz pierwszy występuje przeciw mnie w tej sprawie.

tropolita Monachium i Fryzyngi (1917-1952), od 1921 roku kardynał. Faulhaber Michael von, w: $D B E, 3$, München 1996, s. 235.

435 Załącznik nie zachował się.

436 Sigismund Waitz (1864-1941) - austriacki duchowny katolicki, arcybiskup metropolita diecezji Salzburg (1934-1941). Hierarchia Catholica, 9, s. 127.

437 Karel Kašpar (1870-1941) - czeski duchowny katolicki, arcybiskup metropolita Pragi (1931-1941), od 1935 roku kardynał. Hierarchia Catholica, 9, s. 318.

${ }^{438}$ Prawdopodobnie chodzi o biogram Teresy Neuman, opublikowany w wydawnictwie, którego redaktorem był biskup Michael Buchberger: M. S., Neumann Therese, w: Lexikon für Theologie und Kirche, 7, Freiburg im Breisgau 1935, kol. 512-515.

439 Georg Wunderle (1881-1950) - niemiecki duchowny katolicki, profesor teologii i filozofii na uniwersytetach w Eichstätt i Würzburgu; prowadził badania w dziedzinie filozofii religii, psychologii religii, historii religii, pedagogiki i innych. J. Has enfuss, Wunderle Georg, w: Lexikon für Theologie und Kirche, 10, Freiburg im Breisgau 1965, kol. 1265-1266.

${ }^{440}$ Niem.: brzydki pamflet. 
d) Jeżeli Konnersreuth jest w ogóle znakiem Bożym, to właśnie dziś w najcięższych dla Niemiec katolickich chwilach potrzeba jest, by znak ten „został wywyższony”, a nie chowany ,pod korzec”, bo właśnie na to Pan Bóg daje te znaki, by ludzi na duchu podnieść i pokrzepić.

W takim razie książka moja pod pewnym względem idzie po linii myśli Bożej i nie kurczy jej.

70.

FKiDOP, t. 140, sygn. 448/150 [7], s. 11, kard. A. Hlond do arcybpa J. Teodorowicza ${ }^{441}$.

Poznań, dnia 28 marca 1937

Ekscelencjo!

Spieszę donieść, że w tej chwili otrzymałem ekspresową przesyłkę. Zapoznam się ze sprawą i jutro napiszę.

Z czcią najgłębszą i serdecznym oddaniem Waszej Ekscelencji powolny sługa i brat

+ August Kard. Hlond ${ }^{442}$

71.

FKiDOP, t. 140, sygn. 448/190 [7], s. 14-15, kard. A. Hlond do arcybpa J. Teodorowicza ${ }^{443}$.

Poznań, dnia 29 marca 1937 r.

Ekscelencjo!

Najdostojniejszy Księże Arcybiskupie!

Jestem wprost przerażony obrotem jaki wzięła sprawa wiadomej publikacji. Najserdeczniej z Waszą Ekscelencją współczuję, bo wmyślam się w tragizm położenia. Chciałbym Waszą Ekscelencję tym pocieszyć, że to samo spotkało św. Jana Bosko ${ }^{444}$, gdy wydał żywot św. Piotra Apostoła ${ }^{445}$ i na wstępie poruszył dogmatyczną stronę kwestii rzymskiej siedziby Papieży. Nazywał to św. Jan Bosko najboleśniejszym krzyżem, jaki go spotkał w ciągu całego tak umęczonego żywota.

${ }^{441}$ Rkps pisany na 1 stronie papieru formatu A4 czarnym atramentem. W lewym górnym rogu znak wodny - herb prymasa Augusta Hlonda.

${ }^{442}$ Własnoręczny podpis autora listu.

${ }^{443}$ Rkps pisany na 2 stronach papieru formatu A4. W lewym górnym rogu: „Prymas Polski”.

444 Jan Bosko (Bosco) (1815-1888) - włoski duchowny katolicki, założyciel Towarzystwa św. Franciszka Salezego (salezjanów), kanonizowany w 1934 roku.

${ }_{445}$ Prawdopodobnie książka: G. Bosco, Vita di San Pietro, principe degli apostoli e primo papa dopo Gesù Cristo, Torino 1856. 
Dopiero w najbliższym dziesięciu dniach zadecyduję o terminie swego wyjazdu do Rzymu. Zależy to od ustalenia terminu pewnych posiedzeń w Kurii rzymskiej, w których z ważnych względów chciałbym wziąć udział. Bardzo chętnie wręczę Ojcu świętemu pismo Waszej Ekscelencji i od siebie sprawę serdecznie poprę.

Z najgłębszą czcią i z serdecznym oddaniem jestem Waszej Ekscelencji powolny sługa i brat w Chrystusie

+ August Kard. Hlond ${ }^{446}$

72.

ASIK, $A H$, t. V, cz. 8, s. 14-17, arcybp J. Teodorowicz do kard. A. Hlonda ${ }^{447}$.

6 kwietnia $1937^{448}$

Wasza Eminencjo,

Prawdziwie wzruszony jestem listem Waszej Eminencji. Nie tylko Wasza Eminencja zgodził się przedstawić moją prośbę Ojcu św., ale raczył mi okazać tyle zrozumienia i tyle współczucia w tym moim doprawdy bardzo a bardzo ciężkim krzyżu.

Pokrzepił mnie Wasza Eminencja przytoczeniem nieznanego mi szczegółu o św. Janie Bosco.

Znam inny szczegół o Biskupie Prohaszce ${ }^{449}$, którego podobny cios spotkał ze strony Św[iętego] Officium. Ja nawet dołączam go do listu do Ojca św., o ile by Wasza Eminencja uważał za wskazane by i to Ojcu św. przedstawić. Opuszczam tylko z pamiętnika Biskupa Prohaszki to co mówi o sobie, iż po tym ciosie strona uczuciowa przywiązana do Stolicy św. została śmiertelnie ugodzona. Tego nie chciałem pisać, zwłaszcza, że Bóg mnie w tym krzepi duchowo i wewnętrznie. Skoro się pisze o Stygmatyczce będącej ekspiacją za grzechy, trzeba wziąc samemu udział w krzyżu i cierpieniu. Im ono dotkliwsze, tym jest lepsze. Ekwiwalentem tego ciosu są dla mnie listy z różnych stron świata, z których widzę jak wiele dobrego ta książka czyni. Posłałem Waszej Eminencji ocenę znanego pi-

${ }^{446}$ Własnoręczny podpis autora listu.

447 Mszps pisany na 4 stronach formatu A4 wraz z załącznikami.

448 Data prezentaty w kancelarii prymasa; list wysłano 3 kwietnia 1937 roku. Zob. kopię tegoż listu: FKiDOP, t. 130, sygn. 22/53 [8], s. 25.

449 Ottokár Prohászka (1858-1927) - węgierski duchowny katolicki wyświęcony w 1881 roku w Rzymie, od 1903 roku profesor uniwersytetu w Budapeszcie, ordynariusz diecezji Székesfehérvár na Węgrzech (1906-1927); w wyniku intryg duchowieństwa węgierskiego w 1911 roku oskarżono go o modernizm, a jego trzy książki znalazły się na Indeksie Ksiąg Zakazanych. J. Puciłowski, Biskup z indeksu kościelnego, „Znak”, 61, 2009, 654, s. 75-83. 
sarza duńskiego (Villama Grönbeka ${ }^{450}$ ) w piśmie Pastorów duńskich. Był u mnie przed paru dniami konsul rumuński z Hamburga, człowiek zresztą niewierzący, który mi za tę książkę dziękował i mówił, że pożyczał ją wielu protestantom, którzy byli nią nadzwyczaj ukrzepieni. Dostałem też głęboki, piękny i krzepiący list od jakiegoś bardzo świątobliwego kapłana ze Strassburga. Przytaczam tych parę szczegółów z ostatnich kilku dni. Sam wydawca pisma pisze mi o błogosławionych skutkach, jakie książka wywiera na umysły i dodaje od siebie, że nigdy nie będzie żałować, że ją wydał.

Dla orientacji załączam tu Waszej Eminencji list z Rzymu pisany do mnie przez Biskupa Przeździeckiego [w] r[oku] $1933^{451}$ i gen[erała] Ledóchowskiego ${ }^{452}$, który jeszcze przed wydaniem mej książki jak widać czynił zabiegi w Św[iętej] Kongregacji.

Jeszcze raz Waszej Eminencji z głębi serca za wszystko dziękuję, w modłach moich żywo pamiętam o Waszej Ekscelencji prosząc przede wszystkim o tak potrzebne dla nas wszystkich zdrowie Waszej Eminencji.

Całuję pierścień i kreślę się najoddańszym sługą

+ Teodorowicz

[Załącznik nr 1 - odpis listu bpa Henryka Przeździeckiego do arcybpa Józefa Teodorowicza]

Ekscelencjo!

21 X 1933 Rzym

Zwrócono się do mnie w Rzymie w sprawie związanej z odpowiedzią Ekscelencji na książkę ks. Siwka, mianowicie z tym, że podobno odpowiedź Ekscelencji ma być thumaczona na inne języki. Otóż chodzi o to, aby przed thumaczeniem Ekscelencji zwrócili się do S[anctum] Officium z zarzutami, które Najdostojniejszy Arcypasterz czyni ks. Siwkowi w związku cum doctrina christiana. Podjąłem się tego zadania mając na uwadze, że może moje pismo dopomoże Ekscelencji w czymkolwiek i dlatego pismo wysyłam z Rzymu, nie czekając na powrót do kraju.

Łączę wyrazy najgłębszej czci oddany w Chrystusie Panu

Henryk Przeździecki bp

${ }^{450}$ Prawdopodobnie Wilhelm Peter Grønbech (1873-1948) - duński historyk kultury, profesor Uniwersytetu w Kopenhadze.

451 Zob. załącznik nr 1 do niniejszego listu.

452 Zob. załącznik nr 2 do niniejszego listu. 
[Załącznik nr 2 - odpis listu o. Włodzimierza Ledóchowskiego SJ do arcybpa Józefa Teodorowicza]

Rzym, dnia 29 III 1934

Ekscelencjo, Najprzewielebniejszy Księże Arcybiskupie!

Przy tej sposobności sądzę, że muszę także wyjaśnić sprawę listu Ks. Biskupa Przeździeckiego, pisanego z Rzymu do Waszej Ekscelencji. Z tego listu W[asza] $\mathrm{E}$ [kscelencja] wnioskował, że za sprawą thumaczenia książki W[aszej] E[kscelencji] chce się wciągać Św[ięte] Oficjum i niejako nim grozić. Pozwalam sobie zwrócić uwagę W[aszej] E[kscelencji], że list ks. Biskupa Przeździeckiego wprawdzie nie był jasny, bo naprędce pisany, ale z niego z pewnością nie wynikało, że Św[ięte] Oficjum zajmuje się sprawą thumaczenia książki W[aszej] $\mathrm{E}$ [kscelencji] i że ze strony jego są jakieś pod tym względem plany. Sens listu ks. B[iskupa] Przeździeckiego był ten, że sam Ekscelencja z zarzutami mógłby się zwrócić do Św[iętego] Oficjum.

Rozmowę z ks. Biskupem Przeździeckim najdokładniej pamiętam. Wyraziłem przed nim żal głęboki z powodu całej tej polemiki, dlatego osobisty, że pochodzi od Dostojnika, z którym łączyły mnie dawniej tak ścisłe węzły do tego stopnia, że ilekroć był ciężko atakowany zawsze najserdeczniej go broniłem, a teraz słyszę, że chce obecną sprawę rozciągać i na inne kraje. Prosiłem wtedy B[iskupa] Przeździeckiego czy nie mógłby w tej sprawie pośredniczyć. Mówiłem jak zupełnie inaczej w podobnych wypadkach rzecz się przedstawiała w takich np. Niemczech czy we Francji. Kiedy tam jeden, drugi Ojciec poszedł za daleko i było nawet niebezpieczeństwo, że Św[ięte] Officium tą sprawą się zajmie, to ks[ięża] Biskupi z własnej woli stawali w obronie naszego Ojca, bo nie jest to w interesie Kościoła jakiegoś kraju, jeżeli jacyś jego księża są podejrzani o prawowiernośćt53. A tutaj kiedy mi się zdaje, że i dla Polski coś zrobiłem, nawet profesora Uniwersytetu jakieś błędy są tak rozgłaszane.

Sądzę, mówiłem znając głęboką miłość W[aszej] E[kscelencji] do Polski, że zamiast polemiki lepiej by było, jeżeliby $\mathrm{W}$ [asza] $\mathrm{E}$ [kscelencja] zwrócił się do Św[iętego] Officium i przedłożył niebezpieczeństwo, jakie by mogło z tej książki Kościołowi zagrażać. Chociaż W[asza] E[kscelencja] o zarzucie co do Św[iętego] Officium później w listach już nie wspomina, początkowego jednak przypuszczenia, że Ekscelencja mógł mnie o coś podobnego podejrzewać nie mogłem sobie w inny sposób wytłumaczyć, jak tylko silnym podnieceniem pod wpływem może nie dość jasnego listu ks. B[iskupa] Przeździeckiego. Wszak podobne postępowanie, które się W[aszej] E[kscelencji] na myśl nasunęło, byłoby z mojej strony niesłychanie niemądrym. Od 26 lat jestem w Rzymie i znam może lepiej niż wielu innych sposób postępowania Kongregacji rzymskich, a w szcze-

453 Pisownia zgodna z oryginałem. 
gólności Św[iętego] Officium i wiem dobrze, jak sekret jest tu ściśle zachowany; zresztą byłbym sam związany sekretem Św[iętego] Officium gdybym nawet coś podobnego wiedział. Oprócz tego taki sposób postępowania byłby z mojej strony niską intrygą, a z łaski Bożej, prócz Recaldów ${ }^{454}$ i Bremerów ${ }^{455}$ nikt mi tego jeszcze nie zarzucił.

Wł[odzimierz] Ledóchowski TJ

73.

FKiDOP, t. 140, sygn. 1713/65 [5], s. 16, kard. A. Hlond do arcybpa J. Teodorowicza ${ }^{456}$.

Poznań, dnia 20 kwietnia 1937

Ekscelencjo!

Jestem głęboko ujęty przemiłym zaproszeniem do Stanisławowa ${ }^{457}$, gdzie mam mieć szczęście odprawić Pontyfikał ${ }^{458}$ z okazji Koronacji Matki Boskiej Łaskawej $^{459}$. Najserdeczniej dziękuję za ten zaszczyt i bardzo uprzejmie donoszę, że z radością przybędę. A przyjadę już dnia poprzedniego do Lwowa, aby w myśl zaproszenia Przewielebnej Kapituły Metropolitalnej Waszej Ekscelencji wziąć udział w uroczystym akcie uniwersyteckim, którym Lwów zamierza uczcić jubileusz kapłański i wielkie zasługi Waszej Ekscelencji ${ }^{460}$. Odjadę ze Lwowa dnia 31 maja rano, aby zdążyć do Częstochowy na zjazd Ziemiaństwa a po drodze złożyć swe życzenia J[ego] E[kscelencji] Księciu Metropolicie Sapieże.

$\mathrm{Z}$ najgłębszą czcią i oddaniem jestem Waszej Ekscelencji powolny sługa i brat w Chrystusie

$$
+ \text { August Kard. Hlond } d^{461}
$$

${ }^{454}$ Osoby niezidentyfikowane.

$455 \mathrm{JW}$.

${ }^{456}$ Mszps pisany na 1 stronie papieru formatu A4. W lewym górnym rogu: „Prymas Polski”, w lewym dolnym rogu adresat: „J[ego] E[kscelencja] Najprzewielebniejszy Ks. Arcybiskup Józef Teodorowicz we Lwowie".

457 Stanisławów - miasto w Małopolsce Wschodniej, po 1918 roku stolica województwa stanisławowskiego; znajdowała się tam też siedziba parafii ormiańskokatolickiej pw. Niepokalanego Poczęcia Najświętszej Marii Panny.

458 Określenie mszy św. pontyfikalnej.

459 Koronacja cudownego wizerunku Matki Bożej Łaskawej z kościoła ormiańskiego w Stanisławowie odbyła się 30 maja 1937 roku. Uroczystościom przewodniczył kardynał August Hlond.

${ }^{460}$ Z okazji 50. rocznicy święceń kapłańskich arcybiskupa Teodorowicza 29 maja 1937 roku na Uniwersytecie Jana Kazimierza we Lwowie odbyła się uroczysta akademia, dalszy ciąg obchodów miał miejsce w Stanisławowie 30 maja i był połączony z uroczystościami koronacyjnymi.

${ }^{461}$ Własnoręczny podpis autora listu. 
FKiDOP, t. 140, sygn. 1712/65 [5], s. 17, kard. A. Hlond do arcybpa J. Teodorowicza ${ }^{462}$.

Ekscelencjo!

Poznań, dnia 28 kwietnia 1937 r.

Bardzo serdecznie dziękuję Waszej Ekscelencji za łaskawe zaproszenie mnie na mieszkanie do siebie, z którego z wdzięcznością skorzystam. Dziękuję też za marcowy numer „Hochlandu”463, w którym z wielkim zainteresowaniem przeczytałem artykuł w znanej sprawie ${ }^{464}$.

Dnia 10 maja wyjadę do Rzymu, gdzie pozostanę tylko 8 dni i gdzie spełnię zlecenia Waszej Ekscelencji. Ponieważ pragnę udać się do Rzymu „bez akompaniamentu", nie rozgłaszam zamierzonej podróży.

Z najgłębszą czcią i oddaniem jestem Waszej Ekscelencji powolny sługa i brat w Chrystusie

+ August Kard. Hlond ${ }^{465}$

75.

FKiDOP, t. 130, sygn. 447/190 [7], s. 122-124, arcybp J. Teodorowicz do kard. A. Hlonda ${ }^{466}$.

Wasza Eminencjo,

Lwów, dnia 6 V 1937 r.

Stokrotne dzięki za list ostatni: cieszę się osobno z tego, iż będę mógł powitać Waszą Eminencję w moim domu.

Dziś donoszę Waszej Eminencji wprost rewelacyjne szczegóły: Wczoraj przejeżdżała przez Lwów do Stanisławowa przybywająca wprost z Rzymu Urszulanka (S. Beata Bartlówna ${ }^{467}$ ). Otóż ta widziała się z księdzem Bogdanowiczem i opowiedziała mu co następuje. W Rzymie po pojawieniu się mojej książki bawił

${ }^{462}$ Mszps pisany na 1 stronie papieru formatu A4. W lewym górnym rogu: „Prymas Polski”, w lewym dolnym rogu: „J[ego] E[kscelencja] Najprzewielebniejszy Ks. Arcybiskup Józef Teodorowicz we Lwowie".

463 „Hochland” - niemieckie czasopismo katolickie założone przez Carla Mutha, ukazywało się w latach 1903-1941, 1946-1971.

464 Zapewne dotyczącej Konnersreuth.

465 Własnoręczny podpis autora listu.

${ }^{466}$ Mszps pisany na 3 stronach papieru formatu A4.

467 Beata Barthel de Weydenthal (1886-1970) - urszulanka Unii Rzymskiej, śluby wieczyste złożyła w 1926 roku, pracowała jako nauczycielka, wychowawczyni i dyrektor szkół prowadzonych przez zgromadzenie, między innymi we Lwowie, Kołomyi, Stanisławowie. Archiwum Prowincjalne Sióstr Urszulanek Unii Rzymskiej w Krakowie, sygn. AZ 396, informacje biograficzne s. Beaty Barthel de Weydenthal. 
O. Richstaetter $\mathrm{SJ}^{468}$ (z Aachen) ${ }^{469}$ znany wróg Konnersreuth, który choć nigdy tam nie był, napisał o Konnersreuth, nie nazywając go zresztą wcale w „Stimmen der Zeit" ${ }^{470}$ artykuł, podając najfałszywsze szczegóły o zjawiskach tamtejszych. Ten sam O. Jezuita po wydaniu mej książki, prostując parę szczegółów dotyczących właśnie jego artykułów, wyraża się o mojej książce z dużym uznaniem, podkreślając jej wartość („Das grosse, eingehende Werk - pisze on - worin die Probleme Konnersreuth mit so grosser Belesenheit, von so vielen Seiten eine neue Beleuchtung erfahren") ${ }^{471}$. Otóż ten Jezuita robił propagandę w Rzymie przeciw mej książce i mnie. Był on u Urszulanek ze Mszą św. i Przełożona Główna, niemka ${ }^{472}$, podejmowała go śniadaniem w parlatorium ${ }^{473}$. Wtedy to zaczął on rozwodzić się nad tym, że Jezuici niemieccy muszą za wszelką cenę moją książkę zniszczyć, że podjęte są starania, ażeby tę książkę dać na indeks, a w każdym razie oni tę książkę wykupują, bo uważają ją za wysoce szkodliwą. Wspominając też o „lekarzach katolickich”, którzy przeciw tej książce występują miał na myśli $\mathrm{D}[\mathrm{okto}] \mathrm{ra}$ Deutscha, który jak się pokazuje jest tylko narzędziem w ręku Jezuitów.

Szczegóły te wszystkie stąd znane są owej zakonnicy, iż przełożona główna widząc, iż chodzi tu o polskiego Biskupa, wezwała ją zaraz i opowiedziawszy cały przebieg rozmowy z O. Richstaetterem, zaczęła ją wypytywać o książkę i jej autora.

Sam napisałem w tej chwili list do Richstaettera, którego kopię przesyłam Waszej Eminencji ${ }^{474}$, ażeby Wasza Eminencja z nią zrobił co będzie uważał za wskazane.

Jezuici robią wprost światową propagandę przeciw tej książce, bo wbrew zapewnieniom Dr. Deutscha, że drukuje swą pracę jako manuskrypt, broszura jego wychodzi obecnie w języku francuskim; na półkach księgarskich u Lethielleux ${ }^{475}$, już zapowiedzianym zostało jej bliskie ukazanie się.

${ }^{468}$ Karl Richstätter (1864-1949) - niemiecki jezuita, profesor ascetyki i mistyki w Kolegium Filozoficzno-Teologicznym we Frankfurcie nad Menem, a następnie na uczelniach katolickich w Akwizgranie i Valkenburgu. Richstätter Karl, w: DBE, 7, München 1998, s. 275.

469 Aachen (Akwizgran) - miasto uzdrowiskowe w Niemczech.

470 „Stimmen der Zeit” - niemieckie czasopismo naukowe wydawane przez oo. jezuitów od 1865 roku. Zawiera publikacje na temat szeroko pojętej kultury chrześcijańskiej. Siedziba redakcji mieści się w Monachium.

471 Niem.: wielkie, szczegółowe dzieło, z którego dowiadujemy się o problemach Konnersreuth z ogromną erudycją, na nowo naświetlone na tak wielu stronach.

472 Pisownia zgodna z oryginałem. Przełożoną generalną urszulanek Unii Rzymskiej w latach 1926-1959 była Marie de St. Jean Martin, Francuzka.

473 Łac.: rozmównica.

474 Załącznik do listu nie zachował się.

475 Prestiżowe wydawnictwo francuskie z siedzibą w Paryżu założone przez Pierre’a Lethielleux w 1864 roku. 
Pokaże się jednak, że mimo Jezuitów, Dr Deutsch jest w ścisłym związku ze znanym Dr. Aignerem ${ }^{476}$, który jako prezes ateistyczno-monadystycznego towarzystwa odznaczył się jako głośny wróg cudów w ogólności, w szczególności zaś cudów w Lourdes ${ }^{477}$. Tyle w tej sprawie.

Nie wiedząc gdzie Eminencja jest posyłam dwa listy identyczne do Rzymu i Poznania.

Przy tej sposobności pozwolę sobie jeszcze zwrócić uwagę Waszej Eminencji, że już rok mija, jak o książce „O Masonerii” ${ }^{478}$, która kursuje wszędzie i wywołuje wielki skandal udowodniono Ks. Kaczyńskiemu, iż z encyklopedii masońskiej wypisał artykuł o masonerii (plagiat). Plagiata, który w dodatku robi wyciągi z dzieła masońskiego, nie powinien być 24 godziny dłużej na czele organu, który jest organem [prasowym Konferencji] Biskupów ${ }^{479}$.

Jeżeli wprost z Rzymu, poza Arcybiskupem, przyszedł nakaz usunięcia Ks. Wyszyńskiego ${ }^{480} \mathrm{z}$ Wydziału Teologii za daleko mniejszą rzecz ${ }^{481}$, to co mówić o takim niebezpiecznym skandalu?

Ale mam jeszcze rzecz inną: mianowicie zrobił się w Warszawie wielki skandal moralny około osoby Ks. Kaczyńskiego. Miał bowiem za sekretarkę dwukrotną rozwódkę, kalwinkę, którą przyjmował na obiady i jeździł z nią autem. Dziś zapadła ona na chorobę kobiecą i leży w szpitalu. Opowiadał mi o tym Ks. Wądołowski ${ }^{482}$, który przybył tu z Warszawy i bawił we Lwowie jeden dzień. Mówił, że cała Warszawa tylko o tym sobie opowiada.

Dowiedziałem się o tym od Ks. Bogdanowicza, że ktoś udawał się do Waszej Eminencji ze skargą na moją diecezję. Bardzo dziękuję Waszej Eminencji, że był

476 Eduard Aigner - niemiecki lekarz, neurolog, autor prac podważających wiarygodność wydarzeń w Konnersreuth, między innymi Zehn Jahre Konnersreuth (Berlin-Friedenau 1939).

477 Lourdes - miasto w południowo-zachodniej Francji słynie z objawień Matki Bożej.

${ }^{478}$ Chodzi o broszurę pt. Masoneria czym jest, a czym nie jest (Poznań 1935), wydaną nakładem Wydawnictwa św. Wojciecha, do której ks. Kaczyński napisał przedmowę.

${ }^{479}$ Tj. Katolickiej Agencji Prasowej.

${ }^{480}$ Michał Wyszyński (1890-1972) - święcenia kapłańskie otrzymał w 1915 roku, doktor teologii Uniwersytetu w Innsbrucku, pracował duszpastersko w Czerniowcach i we Lwowie, w 1924 roku ukończył studia na Wydziale Prawa i Umiejętności Politycznych Uniwersytetu Jana Kazimierza we Lwowie, po habilitacji w 1925 roku objął tam Katedrę Prawa Kanonicznego i wykładał do 1938 roku; uczestnik powstania warszawskiego, po drugiej wojnie światowej pracował naukowo na Uniwersytecie Wrocławskim. J. Wołczański, Wydział Teologiczny, s. 395.

${ }^{481}$ Według relacji ks. Piotra Stacha rzeczywistym powodem usunięcia duchownego z uczelni był jego romans. Oficjalnie przyczyną przejścia na emeryturę były problemy zdrowotne i trwała niezdolność do pracy. Ibidem, s. 399.

482 Zygmunt Wądołowski (1892-1971) - kapłan archidiecezji warszawskiej, święcenia kapłańskie otrzymał w 1918 roku, doktor teologii, kapelan szpitalny, współzałożyciel i redaktor „Tygodnika Warszawskiego”. Katalog kościołów i duchowieństwa archidiecezji warszawskiej na rok 1937, Warszawa 1937, s. 56. 
łaskaw zapytać się co było na rzeczy? Sam nie wiem co by to miało znaczyć? Wśród księży nie ma żadnego skandalu. Kapituła moja żyje wzorowo, zgodnie między sobą. Zakład wychowawczy ${ }^{483}$ przez lata zamknięty, dziś jest w kwitnącym stanie. Jedynie zakonnice ${ }^{484}$ pozostawiają bardzo wiele do życzenia, ale liczę na Ks. Prałata Brossa, na jego wizytację, którą będę zawdzięczał pozwoleniu Waszej Eminencji ${ }^{485}$. Nie rozumiem, do czego by miało się odnosić jakieś tajemne oskarżenie mej diecezji?

Dziękuję raz jeszcze Waszej Eminencji za wszystko z głębi serca, całuję pierścień Waszej Eminencji z czcią i szacunkiem najgłębszym oddany Waszej Eminencji sługa ${ }^{486}$

76.

FKiDOP, t. 140, sygn. 1712/65 [5], s. 18-19, kard. A. Hlond do arcybpa J. Teodorowicza ${ }^{487}$.

Ekscelencjo!

Rzym, dnia 15 maja 1937 r.

W piątek otrzymał Ojciec św. pismo Waszej Ekscelencji. Nie wiedział o niczym albo nie pamiętał, trapi się bowiem, że teraz zupełnie ostatnie swoje zarządzenia zapomina. Już przedtem mówiłem o sprawie Waszej Ekscelencji z J[ego] Em[inencją] Ks. Kardynałem Stanu ${ }^{488}$, który wiedział o postanowieniu Św[iętego] Oficjum, ale nie znał bliżej motywów dekretu. Wspomniał tylko o tym, że wobec wypadków w Niemczech, Konnersreuth wymaga niezmiernie ostrożnego traktowania. Z O. Ledóchowskim nie było mowy o tym zagadnieniu; sam go nie poruszał, a ja $\mathrm{z}$ umysłu unikałem tego tematu nie mając $\mathrm{w}$ tym względzie żadnych poleceń ze strony Waszej Ekscelencji.

Co do zastrzeżeń, o których wspominał Mons[ignor] Pacini ${ }^{489}$ wobec Ks. Kan[onika] Bogdanowicza, nie mogłem się nic konkretnego dowiedzieć w Sekretariacie Stanu. Byli moimi pytaniami zaskoczeni i zdziwieni. Wnioskuję z tego,

${ }^{483}$ Zakład Wychowawczy im. Józefa Torosiewicza był internatem dla ormiańskiej i polskiej młodzieży męskiej uczęszczającej do szkół powszechnych i średnich. Powstał w 1865 roku we Lwowie; funkcjonował do drugiej wojny światowej.

${ }^{484}$ Mowa o zakonie benedyktynek ormiańskich we Lwowie.

${ }^{485}$ Wizytację benedyktynek ormiańskich nie przeprowadził ks. Bross, tylko o. Klemens Dąbrowski OSB w styczniu 1938 roku.

486 Brak podpisu.

487 Rkps pisany na 2 stronach papieru formatu A4 czarnym atramentem. W lewym górnym rogu nadruk: „Prymas Polski”.

${ }^{488}$ Był nim wówczas kardynał Eugenio Pacelli - późniejszy papież Pius XII.

489 Alfredo Pacini (1888-1967) - dyplomata watykański, audytor nuncjatury w Warszawie (1935-1944), od 1967 roku kardynał. S. Wilk, Nuncjatura warszawska w II Rzeczypospolitej, s. 454. 
iż jeśli są skargi, to leżą w Św[iętej] Kongregacji Wschodniej90, z której atoli tą wszą z umysłu unikałem kontaktu. Kto wie, czy Mons[ignor] Pacini nie powiedział więcej niż zamierzał i wiedział.

Pojutrze ruszam w drogę powrotną. Uchwały Synodu Plenarnego zostały z drobnymi poprawkami przyjęte po wyczerpującej analizie, która trwała siedem godzin i zajęła dwie sesje Św[iętej] Kongregacji Soboru.

$\mathrm{Z}$ wyrazami najgłębszej czci i oddania jestem zawsze Waszej Ekscelencji powolny sługa i brat w Chr[ystusie]

+ August Kard. Hlond ${ }^{491}$

77.

ASIK, $A H$, t. V, cz. 3, s. 126, arcybp J. Teodorowicz do kard. A. Hlonda ${ }^{492}$.

\section{Wasza Eminencjo!}

Jeszcze raz z głębi serca dziękuję Waszej Eminencji za takie utwierdzenie i podniesienie mej uroczystości jubileuszowej i aktu koronacyjnego ${ }^{493}$. Całe Pokucie ${ }^{494}$ mówi dziś o Waszej Eminencji i nie przesadzę skoro powiem, iż pomijając sam akt przybycia i roli Waszej Eminencji, wszystkich Wasza Eminencja nie tylko ujął, ale wprost porwał urokiem Swej osoby.

Jedni Żydzi mają żal podobno do Waszej Eminencji, iż pominął na dworcu ich Torę ${ }^{495}$. Tłumaczyłem, iż Wasza Eminencja w ogóle nie widział ich.

A teraz osobno dziękuję Waszej Eminencji za tak skuteczną interwencję w mojej sprawie. Załączam odpis aktu Kongregacji ${ }^{496}$, który właściwie świadczy prawie o cofnięciu się na całej linii. Intryga Ojców [Jezuitów] spaliła na panewce, a prawie równocześnie z nadesłaniem tego aktu otrzymałem gratulacyjne życzenia jubileuszowe O. Ledóchowskiego. Czyżby przypadkowy zbieg okoliczności?

490 Właściwie: Kongregacja dla Kościołów Wschodnich w Rzymie powołana w 1917 roku. Podlegały jej katolickie obrządki wschodnie, między innymi archidiecezja lwowska obrządku ormiańskokatolickiego.

491 Własnoręczny podpis autora listu.

${ }^{492}$ Mszps pisany na 1 stronie formatu A4.

${ }^{493}$ Chodzi o jubileusz pięćdziesięciolecia święceń kapłańskich arcybiskupa J. Teodorowicza połączony z uroczystościami koronacyjnymi łaskami słynącego wizerunku Matki Bożej z kościoła ormiańskiego w Stanisławowie, celebrowane 30 maja 1937 roku.

${ }^{494}$ Pokucie - kraina nad górnym Prutem w Małopolsce Wschodniej, obecnie na obszarze Ukrainy Zachodniej.

495 Zgodnie z ówczesnym zwyczajem biskupa przybywającego do danej miejscowości witali przedstawiciele duchowieństwa katolickiego różnych obrządków oraz gminy żydowskiej.

496 Zob. załącznik nr 1 do niniejszego listu. 
Niestety, wedle wszelkiego prawdopodobieństwa tak jak bierzemy rzeczy, lekarze mi nie pozwolą na wyjazd do Poznania ${ }^{497}$. Obchód zapowiada się wspaniale i Polska wychodzi w nim na czoło katolicyzmu. To jest istotnie opatrznościowe.

Gdyby to nie było za wiele, to prosiłbym Waszą Eminencję, by chciał wyrazić ode mnie gorącą podziękę tym księżom Biskupom, którzy przybyli na obchód koronacyjny i mój jubileusz jako też tym, którzy przesłali mi życzenia.

Jeszcze raz Waszej Eminencji z głębi serca za wszystko dziękuję w czci najgłębszej zawsze zobowiązany sługa

+ Teodorowicz

Lwów, 20/VI [1]937

Pozwalałam sobie przesłać Waszej Eminencji najnowszą moją książkę ${ }^{498}$.

[Załącznik nr 1 - kopia dekretu Kongregacji Świętego Oficjum ${ }^{499}$ ]

Suprema Sacra Congregazione

del Santo Offizio

Num. di Protoc. 761/27

(nella riposta si prega di citare questo numero)

dal palazzo di S. Offizio

28 maggio 1937

Eccelenza Rev. ma,

Questa Suprema S. Congregazione non ha mancato di prendere in considerazione quanto Vestra Eccelenza Rev. mi ha prospettato circa il disagio, in ciu viene a trovarsi, in seguito alle decisioni comunicate Le con foglio n. 761/27 in data 23 novembre 1936, ed ha altamente aprezzato le ottime disposizioni, con cui si dichiara pronta ad accettare ogni suggerimento di questa S. Congregazione per le eventuali correzioni da introdurre nel suo libro.

Veramente la ragione della misura adottata da questa Suprema non deve ripetersi che dal desiderio di evitare l'inasprimento della controversia suscitata sull'argomento di Konnersreuth, imporre cioè il silenzio sulla questione finché

${ }^{497}$ W dniach 25-29 czerwca 1937 roku w Poznaniu odbył się Międzynarodowy Kongres Chrystusa Króla pod przewodnictwem legata papieskiego kardynała A. Hlonda z udziałem duchowieństwa i wiernych z Europy. Na uroczystości składały się msze św., nabożeństwa, wykłady oraz dyskusje poszczególnych grup językowych. Referaty dotyczyły przyczyn i aktywności ruchu bezbożniczego w Europie, kondycji współczesnego chrześcijaństwa oraz odbudowy życia katolickiego. Międzynarodowy Kongres Chrystusa Króla. Program informator, Poznań 1937, s. 5-9.

498 J. Teodorowicz, Herold Chrystusa na tle epoki.

499 Mszps pisany na 1 stronie formatu A4. FKiDOP, t. 54, sygn. 22/53 [8], s. 29. 
non sia giunto il momento opportuno di occuparsi autorevolmente dell'argomento. E ciè tanto più che, allo stato delle cose, è attesta la delicata situazione della Chiesa nel Reich, vi a motivo di temere complicazioni per altri interventi, che sono con fondamento providibili.

Misura prudenziale, quindi, è non giudizio dottrinale sul libro di V. E. sul quale questa Suprema non ha intesa affato pronunziarsi; tale carattere di misura prudenziale rilevasi anche della circonstanza che, nel Decreto in parola, si invita V.E. a non occuparsi più altro della questione.

Quanto al ritiro degli esemplari delle edizioni già divulgate, questa Suprema subordinava tale invito alla possibilità di effettuarle (,pro posse”), quindi non è intenzione della $\mathrm{S}$. Congregazione di costringere V.E. a far ciò che Le fosse di grave incomodo finanziario e di troppe fastidiose conseguenze per la di Lei posizione e per di Lei prestigio di Arcivescovo.

Per nuove edizioni e traduzioni da farsi, la cosa potrà essere riesaminata quando l'attuale situazione fosse cambiata e i giusti timori sopra detti fossero dissipati.

Nelle fiducia che queste dilucidazioni siano per V.E. pienamente tranquilizzanti mi confermo con distinta stima di V. E. Rev. ma dev. mo

Card. Sbarretti

Vescovo di Sabina e Poggio Misteto Segretario

78.

FKiDOP, t. 140, sygn. 466/190 [7], s. 21, kard. A. Hlond do arcybpa J. Teodorowicza ${ }^{500}$.

Ekscelencjo!

Najserdeczniej gratuluję nadzwyczajnego rzymskiego sukcesu ${ }^{501}$. W danych okolicznościach nie mógł być on pełniejszy. Znać w tym rękę Papieża, z czego się bardzo cieszę.

Nic nie wiedziałem o tym, że na dworcu w Stanisławowie chcieli mnie witać także żydzi ${ }^{502}$, bo nikt mi tego nie zakomunikował. Może i lepiej, że tak się stało.

Żałuję bardzo, że nie będziemy mogli powitać tutaj Waszej Ekscelencji, ale rozumiem dobrze stanowisko lekarzy i dlatego wcale nie nalegam. Zwłaszcza po jubileuszowych trudach należy się Waszej Ekscelencji dużo wypoczynku.

${ }^{500}$ Mszps pisany na 1 stronie formatu A4, brak daty i miejsca nadania. Kopia pisma z datą i miejscem nadania: „Poznań, dn[ia] 23.6.[19]37 Ostrów Tumski 1” znajduje się w: ASIK, $A H$, t. IV, cz. 4, s. 167. W lewym górnym rogu nadruk: „Prymas Polski”, w lewym dolnym rogu adresat: „Jego Ekscelencja Najprzewielebniejszy Ks. Arcybiskup Józef Teodorowicz we Lwowie".

${ }^{501} \mathrm{Na}$ skutek interwencji Piusa XI Kongregacja Świętego Oficjum dekretem z dnia 28 maja 1937 roku anulowała dekret z 23 listopada 1936 roku zabraniający tłumaczeń książki, jej nowych wydań oraz kolportażu dotychczasowego nakładu. Zob. załącznik do listu arcybiskupa J. Teodorowicza do kardynała A. Hlonda z 20 czerwca 1937 roku.

502 Pisownia zgodna $\mathrm{z}$ oryginałem. 
Otrzymałem tom: „Herold Chrystusa na tle epoki”. Gratuluję i bardzo dziękuję. Z prośbą o westchnienie na intencję Kongresu Chrystusa Króla jestem z najgłębszą czcią Waszej Ekscelencji powolny sługa i brat w Chrystusie

+ August Kard. Hlond ${ }^{503}$

79.

ASIK, $A H$, t. IV, cz. 4, s. 168, kard. A. Hlond do arcybpa J. Teodorowicza ${ }^{504}$.

Ekscelencjo!

$\mathrm{W}$ jednym z pism hitlerowskich znalazłem załączone artykuły ${ }^{505} \mathrm{~W}$ sprawie Konnersreuthu. Pozwalam sobie przesłać je Waszej Ekscelencji a zarazem zapytuję uprzejmie o zdrowie i powodzenie.

Z serdecznymi życzeniami świątecznymi i wyrazami najgłębszej czci jestem Waszej Ekscelencji powolny sługa i brat w Chr[ystusie]

$\mathrm{Hl}[\mathrm{ond}]$
$\mathrm{P}[$ oznań], 11 XII [19]37

80.

ASIK, $A H$, t. V, cz. 3, s. 127, arcybp J. Teodorowicz do kard. A. Hlonda ${ }^{506}$.

Lwów, dnia 13 XII 1937 r.

Wasza Eminencjo,

Jestem prawdziwie wzruszony dowodem łaskawości i względów Waszej Eminencji, a zarazem wprost podziwiam, jak stać Waszą Eminencję na baczenie na takie kwestie, jak właśnie artykuł przysłany mi w piśmie. Jest to dla mnie oczywiście informacja niesłychanie cenna, za którą z głębi serca dziękuję.

Kiedyś opiszę Waszej Eminencji obszernie o sprawie Konnersreuth, której dziś bronią w Rzymie Kardynał Kaspar i Arcybiskup Salzburski.

Jak mnie świeżo z Konnersreuth informują, Teresa Neumann oświadczyła Biskupowi Buchbergerowi, że gotowa uciec z domu, by się poddać obserwacji wbrew woli ojca, ale stawia za warunek, aby Biskup się zobowiązał zapewnić jej utrzymanie do końca życia.

Żałuję bardzo, że nie mogę być na Konferencji507 dla stanu mego zdrowia. Jeśli mi wolno uczynić jaką[ś] uwagę, to lękam się o jedno: jak ze wszystkiego widzę, Żydzi zagrożeni na polu ekonomicznym, starają się rozbudzić prąd za

${ }^{503}$ Własnoręczny podpis autora listu.

504 Mszps pisany na 1 stronie formatu A4.

505 Załączniki do listu nie zachowały się.

506 Mszps pisany na 1 stronie formatu A4.

507 Konferencja Episkopatu Polski odbyła się 15 grudnia 1937 roku w Warszawie. 
parcelacją ziemi u chłopów i tak odwrócić uwagę od siebie. Dlatego Kościół musi być niesłychanie ostrożny, aby z jednej strony nie stać się narzędziem interesów żydowskich, a z drugiej zaś strony, by nie pójść na żadne kompromisy $z$ falą radykalizmu i komunizmu idącą na nas.

Jak to przyznali biskupi hiszpańscy w swym liście, omylili się w swej całej taktyce, chcąc pozyskać kompromisowe-radykalne sfery. Tę samą rolę spełniło Centrum $^{508}$ w Niemczech - niestety pod wpływem Rzymu, a naporem hitleryzmu, który dzięki Centrum doszedł do władzy. We Francji idą na ten kierunek ludzie tej miary co Maritin ${ }^{509} \mathrm{i}$ inni.

Dziękuję przy sposobności Waszej Eminencji za zainteresowanie się mym zdrowiem, które po Rabce względnie jest doskonałe, jakkolwiek nie pozwoli mi na ekspedycje takie, jak do Warszawy. Siedzę w domu i piszę. Nową książkę o Chrystusie Panu ${ }^{510}$ mam już na ukończeniu.

Jeszcze raz najgoręcej dziękuję Waszej Eminencji za Jego tak cenną pamięć i całując pierścień Waszej Eminencji kreślę się z wyrazami oddanymi najgłębszej czci

+ Teodorowicz

81.

ASIK, $A H$, t. V, cz. 3, s. 128, arcybp J. Teodorowicz do kard. A. Hlonda ${ }^{511}$.

Wasza Eminencjo!

Lwów, dnia 26 II 1938 r.

Jestem prawdziwie wzruszony pamięcią Waszej Eminencji i szczególnie dziękuję za przysłaną mi niemiecką gazetę o Konnersreuth. Wyszła już odpowiedź, której jeszcze nie dostałem z księgarni. Pseudonim autora jest Veremandus. Podobno kryje się pod tym pseudonimem znany autor niemiecki, zajmujący się mistyką - Bruno Grabiński ${ }^{512} \mathrm{z}$ Wiesbadenu. Drugą odpowiedź przygotowuje dr Hynek z Pragi.

${ }^{508}$ Niemiecka Partia Centrum - partia polityczna założona w 1870 roku w Niemczech, reprezentowała środowiska katolickie i głosiła chrześcijańskie wartości. W latach 1933-1945 przestała istnieć, reaktywowana po drugiej wojnie światowej, nie odzyskała dawnych wpływów, istnieje do dzisiaj.

509 Jacques Maritain (1882-1973) - francuski filozof, teolog i myśliciel polityczny. S. Kowalczyk, Maritain Jacques, w: EK, 11, Lublin 2006, kol. 1383-1387.

510 Przypuszczalnie chodzi o kolejny tom z serii o życiu Chrystusa, który nigdy nie ukazał się drukiem.

${ }^{511}$ Mszps pisany na 1 stronie formatu A4. W lewym dolnym rogu: „Jego Eminencja Ks. Prymas Kardynał August Hlond Poznań”.

512 Bruno Grabinski - autor znanych prac z dziedziny mistyki, między innymi Das Phänomen der Stigmatisation. Mit einer Würdigung der Stigmatisationsfälle aus neuester Zeit, München 1929. 
Ciekawe jednak i niesłychanie silne są artykuły w „Kirchenzeitung”513. Jeden jest poprzedzony wstępem Biskupa Salzburskiego Waitza, co jest tym dziwniejsze, że artykuł zwraca się przeciw Biskupowi Regensburskiemu Buchbergerowi. Drugi artykuł księdza Nabera, który pierwszy raz się odezwał w sprawie Konnersreuth w bardzo prostych i silnych słowach.

O swojej pracy już nie piszę nic, gdyż p[an] Stefan Dąbrowski musiał mówić Waszej Eminencji o tym.

Jestem prawdziwie zdumiony, jak Wasza Eminencja wszystkim się interesuje i niczego z oczu nie spuszcza.

Przy tej sposobności wyrażam podziękowanie i uznanie dla prześlicznego wydawnictwa, nawet w jego zewnętrznej formie - uchwał Synodu ${ }^{514}$.

Modląc się o zdrowie Waszej Eminencji, łączę dla Waszej Eminencji moje najoddańsze wyrazy najgłębszej czci

+ Teodorowicz

82.

ASIK, $A H$, t. V, cz. 4, s. 90, arcybp J. Teodorowicz do kard. A. Hlonda ${ }^{515}$.

Wasza Eminencjo!

Lwów, dn[ia] 10 III 1938 r.

Bardzo dziękuję Waszej Eminencji za tak dla mnie cenne słowa zachęty, które mi Wasza Eminencja przesyła. Dziękuję osobno za świeżo przysłany mi dokument ataków Aignera sprzymierzonego niestety z katolikiem (Dr Deutsch) mającym taki wpływ na chorego zresztą człowieka, jakim jest biskup Buchberger.

Jeszcze raz dziękując, łączę wyrazy mojej czci bardzo oddanej i głębokiej, sługa w Chrystusie

+ Teodorowicz

513 Właściwie „Katholische Kirchenzeitung” - periodyk o tematyce religijnej wydawany w Salzburgu w latach 1861-1939.

514 Primum Concilium Plenarium Polonicum: anno domini MCMXXXVI Częstochowiae habitum: Francisco S. ROKUE. card. Marmaggi summi pontificis Pii Pp. XI legato apostolico praeside. Decreta, Poznań 1937.

515 Mszps pisany na 1 stronie formatu A4. 


\section{3.}

ASIK, $A H$, t. V, cz. 3, s. 129-131, arcybp J. Teodorowicz do kard. A. Hlonda ${ }^{516}$.

Wasza Eminencjo!

Lwów, dnia 21 marca 1938 r.

Dziękuję Waszej Eminencji za łaskawy list, tak mi cenny i za zachętę jaką otrzymuję od Waszej Eminencji w głoszeniu moich przemówień.

Dziękuję osobno za nowy przysłany wycinek niemiecki, z którego widzę [jak] racjonalista Aigner wybornie uchwycił słabą i połowiczną pozycję Regensburskiego Biskupa w sprawie Konnersreuth. Wyzyskał on ją wprost w niemiłosierny sposób.

Pisał mi p[an] Dąbrowski, iż mówił z Waszą Eminencją o moim rzekomym sprzeciwie w sprawie przeprowadzania drugiej obserwacji ${ }^{517}$. Mówię o „rzekomym" sprzeciwie, gdyż jeszcze w książce mojej wyrażałem zdanie, że druga obserwacja, skoro jej Biskupi żądają - powinna się odbyć. Wobec tego jednak, że jak widzę z listu p[ana] Dąbrowskiego, Wasza Eminencja raczył się tym zainteresować, pozwalam sobie przesłać odpis mojego listu do p[ana] Dąbrowskiego.

Skorzystam ze sposobności, aby Waszej Eminencji osobne jeszcze wyrazić podziękowanie za klasyczny wprost komentarz do ustaw synodalnych, który ujmuje najważniejsze nasze problemy. Dopiero teraz zapoznaję się z treścią tego listu lepiej i widzę, jak szerokie są, a zarazem jak realne i aktualne problemy w nim poruszone.

Całuję pierścień Waszej Eminencji i łączę wyrazy najgłębszej czci

+ Teodorowicz

[Załącznik - odpis listu arcybpa Józefa Teodorowicza do prof. Stefana Dąbrowskiego]

Kochany Panie Profesorze,

Lwów, dnia 17 marca 1938 r.

Bardzo dziękuję Panu Profesorowi za list pański, który mi sprawił dużą pociechę. Bo nareszcie nie różnimy się właściwie w naszym stanowisku zasadniczym wcale.

Panu Profesorowi zależy całkiem słusznie na tym, aby Teresa Neumann była poddana obserwacji, dlatego że żądają tego Biskupi i domaga się Kongregacja.

Lecz ja w mej książce ${ }^{518}$, a więc przed dwoma laty, pisałem to samo i robiłem starania, by druga obserwacja przyszła do skutku właśnie dlatego, że tego sobie życzyli XX. Biskupi. Takie same stanowisko już jest zajęte przeze mnie w tej

516 Mszps pisany na 3 stronach formatu A4.

517 Chodzi o obserwację lekarską mistyczki Teresy Neumann.

518 J. Teodorowicz, Konnersreuth im Lichte. 
nowej pracy. W szczególności wspominam o projekcie Pana Profesora szklanego domu.

Tak samo nie będę o to kopii kruszył, jak długo ma trwać ta obserwacja czy 2 tygodnie, czy jak tego żąda Deutsch - miesiąc. Z tego względu nie mam nic przeciw, jeśli Pan Profesor wyrazi - jak Hehn ${ }^{519}$ to czyni - potrzebę nowej obserwacji.

Tak samo zaznaczył Pan Profesor w swej pracy różnicę zasadniczą pomiędzy samą obserwacją, która wystarczy dla stwierdzenia iż nie ma oszustwa, a klinicznymi zabiegami. Dzięki właśnie temu rozróżnieniu zgadzam się na to, aby prawie cała praca Pana Profesora ${ }^{520}$ była umieszczona. Prosiłem tylko o skreślenie ostatniego ustępu, który wywołuje u czytelnika wrażenie, że cały problem obserwacji polega na klinicznych zabiegach. Ten ustęp przyczynić się mógł tylko do tego, że Neumann córki swej pod obserwację nie odda. Nikt bowiem nie ma prawa narzucać klinicznych zabiegów, a on się zastrzegł przeciw temu.

Ja nie mówię o tym, o czym pisałem Panu Profesorowi poprzednio, tj. o zasadniczym stanowisku Kościoła w tym względzie zawartym w aktach i bullach kanonizacyjnych. Pomijając już inne względy, byłaby dla mnie ogromna szkoda, gdyby Pan Profesor sam swojej pracy nie podpisał, nie tylko ze względu na samą pracę i jej wartość, lecz zależało mi bardzo, by imię Pana Profesora w Niemczech jako uczonego zabłysło. Prosiłem Pana Profesora o Jego udział i rzeczywiście praca Pana Profesora - wedle orzeczenia Prof. Koskowskiego ${ }^{521}$ - jest znakomitą.

Dodam tu jeszcze i to, że powoływanie się na Dr. Ewalda ${ }^{522}$, iż ma słuszność nie odpowiada stanowisku, jakie Dr Ewald zajął. Bo racje Dr. Ewalda są zupełnie inne niż racje Pana Profesora. Ewald nie apeluje do nowych klinicznych zabiegów. Ale to już drobiazg, którego dotykam mimochodem. Dlatego sądziłem, że Pan Profesor może ogólnie zaznaczyć, bo tego domagają się Biskupi - i żądać, by to Uberwachung ${ }^{523}$ odbyło się w takich warunkach, jakie dzisiaj nauka za najlepsze przewiduje, tj. w szklanym domu.

O nowych zabiegach można by pisać z zastrzeżeniami, aby uchylić niejasność i nieścisłość, iż one dla samej obserwacji nie są konieczne, lecz mogą posłu-

519 Postać niezidentyfikowana.

520 Przypuszczalnie chodzi o kilkunastostronicowy maszynopis: FKiDOP, t. 139, sygn. 1281/365 [5], S. Dąbrowski, Paradoxer metabolismus im Falle der Therese Neumann von Konnersreuth, [Poznań 1938].

521 Włodzimierz Koskowski (1893-1965) - farmakolog, profesor Wydziału Lekarskiego Uniwersytetu Jana Kazimierza we Lwowie, po drugiej wojnie światowej pracował naukowo w Edynburgu i Aleksandrii. A. Straszyński, Koskowski Włodzimierz, w: Polski słownik biograficzny, 14, Wrocław-Warszawa-Kraków 1968-1969, s. 233-234.

${ }_{522}$ Gottfried Ewald (1888-1963) - niemiecki neurolog i psychiatra, profesor medycyny na Uniwersytecie w Getyndze; kierował zespołem medycznym prowadzącym badania Teresy Neumann w 1927 roku. Ewald Gottfried, w: DBE, 3, München 1996, s. 197.

${ }^{523}$ Właściwie: überwachung - niem.: nadzór, obserwacja. 
żyć dla zaspokojenia ciekawości lekarskiej. To zresztą wynika z założenia Pana Profesora.

Dziękuję Panu Profesorowi i Pani za słowa tak łaskawe, a dla mnie tak cenne o moich przemówieniach. Zastosuję się też do życzenia Pana Profesora i w następnym przemówieniu, odpowiada mi to bardzo. A ta lekkomyślność z jaką się u nas traktuje zabór Austrii, a usadowienie się w środkowej Europie Niemiec ${ }^{524}$, jest wprost nie do pojęcia! Trzeba istotnie zaślepienia takiego organizmu Związku Ludowo-Narodowego ${ }^{525}$, ażeby Niemcom dostarczać materiału dla usprawiedliwiania ich gwałtu, który dziś spotyka Austrię, a jutro się na nas zamierzy. Polska staje się obecnie zupełnie osamotnioną: z jednej strony Niemcy, z drugiej strony przez nich popierana Ukraina, tam znów Litwa wroga, w końcu Rosja. I w takich to warunkach obóz narodowy pieje prawie peany w cześć hitleryzmu.

Będę bardzo zobowiązany Panu Profesorowi, jeżeli zechce ostatecznie rozstrzygnąć całą sprawę z manuskryptem. Już trzeci urgens dostaję z Niemiec, gdzie mi piszą, że dalej czekać nie mogą, gdyż sprawa przestanie być zupełnie aktualną.

Łączę dla Państwa moje bardzo serdeczne pozdrowienia i zawsze oddane wyrazy mej czci głębokiej ${ }^{526}$

84.

ASIK, $A H$, t. V, cz. 3, s. 132, arcybp J. Teodorowicz do kard. A. Hlonda ${ }^{527}$.

Wasza Eminencjo!

Bardzo serdeczną i bardzo gorącą podziękę składam za przysłane życzenia. Wyrażam przy tym szczerą radość, że Pan Bóg przywrócił zupełnie zdrowie i tak potrzebne dla Waszej Eminencji sily.

Całuję pierścień Waszej Eminencji i łączę wyrazy pełnej czci

+ Teodorowicz

${ }^{524}$ Aluzja do Anschlussu Austrii przez Niemcy dokonanego 12 marca 1938 roku.

${ }^{525}$ Związek Ludowo-Narodowy - polska partia polityczna działająca w latach 19191928, skupiająca polityków prawicowych o poglądach narodowych i konserwatywnych; jedna z form organizacyjnych Narodowej Demokracji.

526 Brak podpisu.

${ }_{527}$ Mszps pisany na 1 stronie formatu A4. Data prezentaty w kancelarii prymasa: „23 ma$\mathrm{rz}[\mathrm{ec}] 1938^{\prime}$. 
85.

ASIK, $A H$, t. IV, cz. 1, s. 38, kard. A. Hlond do arcybpa J. Teodorowicza ${ }^{528}$.

\section{Ekscelencjo!}

Donoszę uprzejmie Waszej Ekscelencji, iż kierownicze instancje Radia Polskiego zostały o tym powiadomione, iż nie jest dopuszczalne wydawanie publicznych sądów przez Radio o transmitowanych kazaniach Księży Biskupów. Oświadczenie to stało $\mathrm{w}$ związku z wielkopostnymi przemówieniami Waszej Ekscelencji, które swą treścią odpowiadały wychowawczej tendencji państwowej, tylokrotnie podkreślane przez czynniki rządowe.

Kierownicze instancje Polskiego Radia zostały również poinformowane o uchwale Konferencji Episkopatu w odniesieniu do Kazań Waszej Ekscelencji. Uchwałę zanotowaną w protokole Konferencji z dnia 10 maja br. przesyłam Waszej Ekscelencji w brzmieniu dosłownym: „Prezes Radia polskiego skrytykował pewne oświadczenie w pasyjnym kazaniu Arcybiskupa Teodorowicza transmitowanym przez Radio Polskie. Biskup Adamski zajmujący się z ramienia Episkopatu sprawą transmitowania nabożeństw i kazań drogą radiową, wyjaśnia naprzód umowę radiową zawartą co to tego z Radiem, a następnie komunikuje swą rozmowę z tym Prezesem w sprawie jego wystąpienia wobec kazania Arcybiskupa Teodorowicza. Episkopat uważa wystąpienia Radia Polskiego tak wobec Arcybiskupa Teodorowicza jak i w innych sprawach kościelnych i religijnych za niedopuszczalne i prosi Biskupa Adamskiego o oświadczenie dyrekcji Radia Polskiego z powołaniem się na Konferencję Episkopatu, że kazanie Arcybiskupa Teodorowicza nie wykroczyło w niczym poza kompetencje biskupa nauczającego wiernych i że biskup ma prawo piętnowania objawów antychrześcijańskich i antyreligijnych w kraju".

Wobec tego, że oświadczenie złożone Jego Ekscelencji Ks. Biskupowi Adamskiemu przez czynniki kierownicze Polskiego Radia poczytywać można za wytłumaczenie tego, co się stało i za rękojmię na przyszłość, donoszę bardzo uprzejmie, że Kongregacja Episkopatu zebrana w Częstochowie dnia 26-go września br. uznała przykry ten incydent za załatwiony w myśl wniosku Waszej Ekscelencji i zgodnie z postulatem katolickiej opinii publicznej ${ }^{529}$.

$\mathrm{Z}$ najgłębszą czcią i oddaniem

August Kard. Hlond

${ }^{528}$ Mszps pisany na 1 stronie formatu A4. List opublikowano w: „Dziennik Poznański”, 80, 1938, 242, s. 2 oraz w: A. Hlond, Dzieła. Nauczanie 1897-1948, 1, red. J. Konieczny, Toruń 2003, s. 636-637.

${ }^{529}$ Szerzej o tej sprawie zob.: M. Szczepaniak, Spirala pomówień czy walka o dusze? Wokół polityki na ambonie w kazaniu radiowym arcybiskupa Teodorowicza, „Śląskie Studia Historyczno-Teologiczne", 46, 2013, 1, s. 129-146. 
86.

ASIK, $A H$, t. IV, cz. 1, s. 39, kard. A. Hlond do arcybpa J. Teodorowicza ${ }^{530}$.

Ekscelencjo!

Dowiaduję się o zasłabnięciu Waszej Ekscelencji. W serdecznym oddaniu śpieszę z życzeniami rychłego powrotu do zdrowia, o które w Przenajświętszej Ofierze modlę się wraz z tylu przyjaciółmi i czcicielami Waszej Ekscelencji.

Z najgłębszą czcią jestem Waszej Ekscelencji powolny sługa i brat w Chrystusie.

+ August Kard. Hlond Poznań, dnia 21 XI 1938 r.

87.

ASIK, $A H$, t. IV, cz. 1, s. 39, arcybp J. Teodorowicz do kard. A. Hlonda ${ }^{531}$.

Za śliczne słowa pociechy z głębi serca dziękuję Waszej Eminencji.

Teodorowicz

\section{Bibliografia}

\section{Źródla archiwalne}

Archiwum Fundacji Kultury i Dziedzictwa Ormian Polskich w Warszawie, spuścizna arcybpa Józefa Teodorowicza, Korespondencja z kard. Augustem Hlondem

Archiwum Kurii Metropolitalnej Krakowskiej, sygn. TS XII/ 139, Protokół Konferencji Komisji Prawnej Episkopatu Polski, Warszawa 19-20 VI 1934

Archiwum Prowincjalne Sióstr Urszulanek Unii Rzymskiej w Krakowie, sygn. AZ 396, informacje biograficzne s. Beaty Barthel de Weydenthal

Archiwum Salezjańskie Inspektorii Krakowskiej w Krakowie, Acta Hlondiana. Materiaty do życia i działalności kardynała Augusta Hlonda Prymasa Polski, oprac. S. Kosiński, Ląd nad Wartą 1966, mszps

\section{Źródła drukowane}

Aleksander Kakowski posłaniec wolności. Zeszyt dokumentacyjny, oprac. W. Krzyżewski, Warszawa 2017

Hierarchia Catholica medii et recentioris aevi, sive Summorum pontificum - S. R. E. cardinalum ecclesiarum antistitum series: e documentis tabularii praesertim Vaticani

${ }^{530}$ Mszps pisany na 1 stronie formatu A4. List został opublikowany na łamach czasopisma „Gregoriana”, 1938, 4, s. 204.

${ }^{531}$ Mszps pisany na 1 stronie formatu A4. List opublikowany został na łamach czasopisma „Gregoriana”, 1938, 4, s. 204. 
collecta, digesta, edita, 9, a pontificatu Pii PP. X (1903) usque ad pontificatum Benedicti PP. XV (1922), wyd. Z. Pięta, Patavii 2002.

Hlond A., Dzieła. Nauczanie 1897-1948, 1, red. J. Konieczny, Torun 2003

Hlond A., O życiu parafialnym. Wielkopostny list pasterski, Poznań 1933

Index librorum prohibitorum Leonis XIII summi pontificis auctoritate recognitus SSMI D. N. Pii PP. XI iussu editus, Romae 1925

Katalog kościołów i duchowieństwa archidiecezji warszawskiej na rok 1937, Warszawa 1937

[List arcybpa J. Teodorowicza do kard. A. Hlonda], „Gregoriana”, 1938, 4, s. 204

[List kard. A. Hlonda do arcybpa J. Teodorowicza], „Dziennik Poznański”, 80, 1938, 242, s. 2

[List kard. A. Hlonda do arcybpa J. Teodorowicza, Poznań 21 listopada 1938], „Gregoriana", 1938, 4, s. 204

List pasterski Biskupów Polskich w sprawie wyborów, Warszawa 6 XII 1927, „Miesięcznik Kościelny dla Archidiecezji Gnieźnieńskiej i Poznańskiej”, 42, 1927, 11-12, s. $63-65$

List pasterski J[ego] Em[inencji] Ks. Kardynała Prymasa o katolickie zasady moralne, Poznań 1936

Międzynarodowy Kongres Chrystusa Króla. Program informator, Poznań 1937

O ducha chrześcijańskiego w Polsce. List pasterski Episkopatu Polski, Płock [1934]

Odezwa J[ego] Em[inencji] Ks. Kardynała Prymasa w sprawie „Święta Młodzieży”, „Miesięcznik Kościelny dla Archidiecezji Gnieźnieńskiej i Poznańskiej”, 47, 1932, 10, s. 89

Primum Concilium Plenarium Polonicum: anno domini MCMXXXVI Częstochowiae habitum: Francisco S. R. E. card. Marmaggi summi pontificis Pii Pp. XI legato apostolico praeside. Decreta, Poznań 1937

Rocznik archidiecezji gnieźnieńskiej i poznańskiej na 1938 rok, Poznań 1938

Rocznik archidiecezji poznańskiej na rok tysiaclecia 1968, Poznań 1968

Schematyzm diecezji tarnowskiej 1987, Tarnów 1987

Uchwały I Polskiego Synodu Plenarnego odbytego w Częstochowie w dniach 26-27 VIII 1936 oraz orędzie Episkopatu Polskiego w sprawie uchwat synodu, Poznań 1938

Wołczański J., Listy arcybiskupa Józefa Teodorowicza do arcybiskupa Józefa Bilczewskiego z lat 1900-1923, cz. 1, 1900-1901, „Przegląd Wschodni”, 8, 2003, 4, s. 9771019; cz. 2, 1902-1913, ibidem, 9, 2004, 2, s. 379-429; cz. 3, 1914-1923, ibidem, 9, 2006, 4, s. 803-838

Wołczański J., Listy biskupa Józefa Sebastiana Pelczara do arcybiskupa Józefa Bilczewskiego z lat 1889-1923, w: Święty Józef Sebastian Pelczar (1842-1924). Rektor Uniwersytetu Jagiellońskiego i biskup przemyski, red. A. Kubiś, J. Wołczański, Kraków 2005, s. 207-358

Z życia Kościoła Chrystusowego. List pasterski Jego Eminencji Ks. Kardynała Prymasa, „Miesięcznik Kościelny dla Archidiecezji Gnieźnieńskiej i Poznańskiej”, 50, 1935, 4, s. $117-130$

\section{Opracowania}

Adam K., Das Wesen des Katholizismus, Augsburg 1924

Aigner E., Zehn Jahre Konnersreuth, Berlin-Friedenau 1939 
Benoit L., Les phénomènes extatiques et leurs dérivés chez Thérèse Neumann, „Études carmélitaines. Mystiques et missionaires", 1933, 1, s. 39-51

Bibliografia katolickich czasopism religijnych w Polsce 1918-1944, red. Z. Zieliński, Lublin 1981

Bielawny K., Ignacy Wysoczański - biskup Kościoła Starokatolickiego i Kościołów Wschodnich, w: Biskup - prezbiter - diakon. Perspektywa polskokatolicka i rzymskokatolicka, red. J. Jezierski, Olsztyn 2008, s. 187-199

Biographisches Lexikon des Kaiserthums Oesterreich, 7, red. C. von Wurzbach, Wien 1861

Bogdanowicz A., O logike w mistyce, „Gazeta Kościelna”, 41, 1934, 8, s. 80-82; 41, 1934, 12, s. 132-134

Bosco G., Vita di San Pietro, principe degli apostoli e primo papa dopo Gesù Cristo, Torino 1856

Bukowicz J., Świadkowie wiary. Marianie prześladowani przez hitleryzm i komunizm, Warszawa 2001

Chajko G., Arcybiskup Bolesław Twardowski (1864-1944). Metropolita lwowski obrzadku łacińskiego, Rzeszów 2010

Deutsche Biographische Enzyklopädie, 1-3, 6-7, 9, red. W. Killy, München 1995-1998

Encyklopedia katolicka, 1, 5, 8, 11, 15, Lublin 1985, 1989, 2000, 2006, 2011

Encyklopedia wiedzy o jezuitach na ziemiach Polski i Litwy 1564-1995, oprac. L. Grzebień, Kraków 1995

Fokciński H., Wspomnienie o Zofii Olszamowskiej Skowrońskiej, „Kronika Rzymska”, 1983, 2, s. 13-15

Garlicki A., Józef Piłsudski 1867-1935, Kraków 2017

Gawlik S., Życie i działalność ks. arcybpa Józefa T. Teodorowicza, Kraków-WarszawaStruga 1988

Grabiński B., Das Phänomen der Stigmatisation. Mit einer Würdigung der Stigmatisationsfälle aus neuester Zeit, München 1929

Iwicki J., Charyzmat Zmartwychwstańców. Historia Zgromadzenia Zmartwychwstania Pańskiego, 2, 1887-1932, Kraków-Kielce 2007

J. N., Konnersreuth, „Czas”, 1934, 36, s. 4

Jachowski J., Lisiecki Arkadiusz Marian, w: Polski słownik biograficzny, 17, WrocławWarszawa-Kraków 1972, s. 453-454

Jakubek M., Prasa krakowska 1795-1918. Bibliografia, Kraków 2004

Kajzar P., Mauzoleum marszałka Józefa Piłsudskiego na Wawelu w latach 1935-1989, Kraków 2018

Kanonicy Kapituly Katedry Gnieźnieńskiej 1918-2009, red. B. Czyżewski, K. Wętkowski, Gniezno 2010

Kardynat August Hlond (1881-1948). Pasterz - nauczyciel - świadek, red. M. Grygiel, Poznań 2010

Kinasz A., Błogosławiona Marcelina Darowska - życie i działalność w służbie Bogu, ojczyźnie, społeczeństwu, „Folia Historica Cracoviensia”, 15/16, 2009/2010, s. 375390

Kostkiewicz J., Kierunki i koncepcje pedagogiki katolickiej w Polsce 1918-1939, Kraków 2013 
Kosyra-Cieślak H., Krzyżami zdobyłeś serce moje. Matka Józefa Karska niepokalanka 1823-1860, Szymanów 2002

Kowalski K., Międzynarodowy Kongres Filozofii Tomistycznej w Poznaniu, „Collectanea Theologica", 16, 1935, 1, s. 134-139

Krasowski K., Biskupi katoliccy II Rzeczypospolitej. Słownik biograficzny, Poznań 1996

Król-Mazur R., Działalność polityczna arcybiskupa Józefa Teofila Teodorowicza w latach 1888-1923, Kraków 2013

Krzyżowski T., Archidiecezja lwowska obrządku ormiańskokatolickiego w latach 19021938, Kraków 2018, rozprawa doktorska napisana pod kierunkiem ks. prof. dr. hab. J. Wołczańskiego na Uniwersytecie Papieskim Jana Pawła II w Krakowie, mszps

Krzyżowski T., Ksiadz profesor Mieczysław Tarnawski (1886-1928). Historyk, wychowawca, patriota, Lwów-Kraków 2012

Krzyżowski T., Kulisy nominacji następcy ormiańskokatolickiego arcybiskupa Lwowa Józefa Teodorowicza, „Lehahayer”, 5, 2018, s. 249-263, https://doi.org/10.12797/ LH.05.2018.05.10

Kto byt kim w Drugiej Rzeczypospolitej, red. J. M. Majchrowski, Warszawa 1994

Leksykon duchowieństwa represjonowanego w PRL w latach 1945-1989, 1, red. J. Myszor, Warszawa 2002

Lexikon für Theologie und Kirche, 7, 10, red. M. Buchberger, H. Höfer, K. Rahner, Freiburg im Breisgau 1935, 1965

Lis A., ,Polonia” wobec najwazniejszych wydarzeń politycznych $w$ Polsce $w$ okresie międzywojennym: zamachu stanu w 1926 r. i procesu brzeskiego, ,Rocznik Historii Prasy Polskiej", 19, 2016, 3, s. 75-90

Łojek J., Myśliński J., Władyka W., Dzieje prasy polskiej, Warszawa 1988

Łuczak Cz., Ks. Piotr Wawrzyniak (1849-1910), Poznań 2000

Madaj K., Żuławnik M., Proboszcz getta, Warszawa 2010

Mager A., Le Problemè scientifique de la Stigmatisation, „Études carmélitaines. Mystiques et missionaires", 1936, 2, s. 143-156

Masoneria czym jest, a czym nie jest, Poznań 1935

Mazur Z., Woroniecki Jacek Adam, w: Słownik polskich teologów katolickich 1918-1981, 7, red. L. Grzebień, Warszawa 1983, s. 431-443

Metropolita Andrzej Szeptycki. Studia i materiaty, red. A. A. Zięba, Kraków 1994

Molenda J., Rostworowski Wojciech Hilary, w: Polski słownik biograficzny, 32, Wrocław-Warszawa-Kraków 1989, s. 246-251

Neue Deutsche Biographie, 19, red. K. Aretin, Berlin 1999

Niezgoda C., Wierny ideałom. Życie, działalność i duchowość Józefa Sebastiana Pelczara (1842-1924), Kraków 1988

Nir R., Rhode Pawet Piotr, w: Polski stownik biograficzny, 31, Wrocław-WarszawaKraków 1988-1989, s. 264-265

Nitecki P., Biskupi Kościoła w Polsce w latach 965-1999. Słownik biograficzny, Warszawa 2000

Nowak A., Słownik biograficzny kapłanów diecezji tarnowskiej 1786-1985, 2, 4, Tarnów 2000, 2004

Pajewski J., Lubomirski Zdzisław, w: Polski słownik biograficzny, t. 18, Wrocław-Warszawa-Kraków 1973, s. 66-69 
Pastuszewski S., Kapłan wagabunda na Zamojszczyźnie, „Archiwariusz Zamojski”, 2013, 12, s. 69-80

Poray-Madeyski de B., Le cas de la visionaire stigmatisée: Thérèse Neumann de Konnersreuth, Paris 1940

Pospieszalski K. M., Roszkowski Antoni, w: Polski stownik biograficzny, 32, WrocławWarszawa-Kraków 1989-1991, s. 260-261

Prokop K. R., Poczet biskupów krakowskich, Kraków 1999

Przybyszewski B., Mazanek Stefan, w: Polski słownik biograficzny, 20, Wrocław-Warszawa-Kraków 1975, s. 288-289

Puciłowski J., Biskup z indeksu kościelnego, „Znak”, 61, 2009, 654, s. 75-83

Siwek P., Konnersreuth $w$ świetle nauki i religii, Kraków 1931

Siwek P., Metody badań zjawisk nadprzyrodzonych. Problem Konnersreuth, Kraków 1933

Słomka A., Rys biograficzny kardynała A. Hlonda, w: August kardynał Hlond na straży sumienia Narodu. Wybór pism i przemówień, Warszawa 1999, s. IX-XV

Słownik pedagogów polskich, red. W. Bobrowska-Nowak, D. Drynda, Katowice 1998

Stownik polskich pisarzy franciszkańskich (bernardyni i franciszkanie ślascy, franciszkanie konwentualni, klaryski oraz zgromadzenia III reguły), red. H. E. Wyczawski, Warszawa 1981

Steuer A., P. Siwek, Metody badań zjawisk nadprzyrodzonych. Problem Konnersreuth, Kraków 1933; J. Teodorowicz, Zjawiska mistyczne i ich thumaczenia (Konnersreuth), Poznań 1933 [recenzja], „Ateneum Kapłańskie”, 20, 1934, 33, s. 83-90

Straszyński A., Koskowski Włodzimierz, w: Polski słownik biograficzny, 14, WrocławWarszawa-Kraków 1968-1969, s. 233-234

Szaniecki P., Ojciec Karol Van Oost, Tyniec 1990

Szczepaniak M., Spirala pomówień czy walka o dusze? Wokół polityki na ambonie w kazaniu radiowym arcybiskupa. Teodorowicza, „Śląskie Studia Historyczno-Teologiczne", 46, 2013, 1, s. 129-146

Teodorowicz J., Herold Chrystusa na tle epoki, Poznań 1937

Teodorowicz J., Konnersreuth im Lichte der Mystik und Psychologie, Salzburg 1936

Teodorowicz J., Mystical Phenomena in the Life of Theresa Neumann, thum. R. Kraus, London 1940

Teodorowicz J., Od Betlejem do Nazaretu, Poznań 1932

Teodorowicz J., Od Jahwy do Mesjasza, Poznań 1936

Teodorowicz J., Św. Paweł Apostoł Narodów, „Prąd”, 17, 1930, 18, s. 209-232, 278-293

Teodorowicz J., Zjawiska mistyczne i ich thmaczenia (Konnersreuth), Poznań 1933

Teodorowicz J., Zjawiska mistyczne i ich tłumaczenia, „Ateneum Kapłańskie”, 18, 1932, 29, s. 1-16, 105-121, 209-229, 313-338

Toruński słownik biograficzny, 1, red. K. Mikulski, Toruń 1998

Urban J., Katedra na Wawelu po 1918 roku, Kraków 2008

Vigouroux F., Bacuez G., Brassac A., Manuel biblique ou Cours d'Écriture Sainte, à l'usage des Séminaires. Ancien Testament, 1-2, Paris 1917, 1920

Wąsicki J., Lisowski Zygmunt, w: Wielkopolski słownik biograficzny, red. A. Gąsiorowski, J. Topolski, Warszawa-Poznań 1981, s. 427

Wilk S., Episkopat Kościoła katolickiego w Polsce w latach 1918-1939, Warszawa 1992 
Wilk S., Nuncjatura Warszawska w II Rzeczypospolitej, w: Nuncjatura Apostolska w Rzeczypospolitej, red. T. Chynczewska-Hennel, K. Wiszowata-Walczak, Białystok 2012, s. $441-455$

Wołczański J., Wydział Teologiczny Uniwersytetu Jana Kazimierza we Lwowie 19181939, Kraków 2002

Zaleski T., Słownik biograficzny duchownych ormiańskokatolickich oraz duchownych rzymskokatolickich pochodzenia ormiańskiego w Polsce w latach 1750-2000, Kraków 2001

Zawadzki R. M., Święta Jadwiga Andegaweńska, „Folia Historica Cracoviensia”, 15/16, 2009/2010, s. 101-110

Zieliński T., Hellenizm a judaizm, 1-2, Kraków 1927

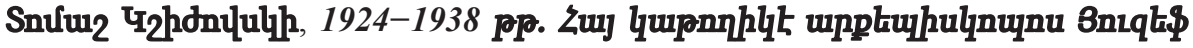

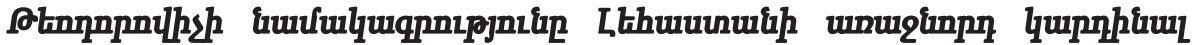 Unzqniuu Ziniung htin}

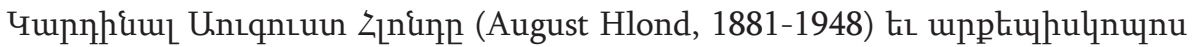

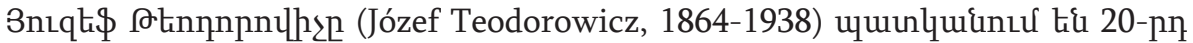

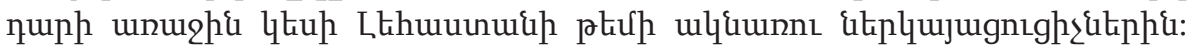

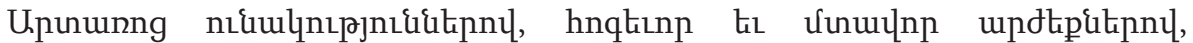

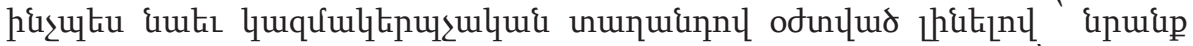

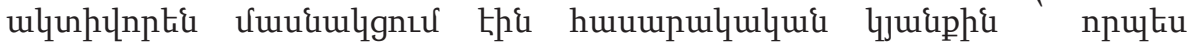

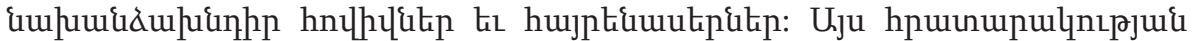

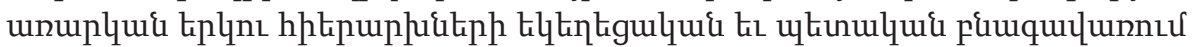

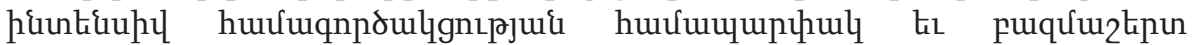

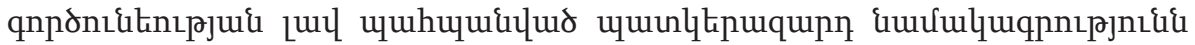

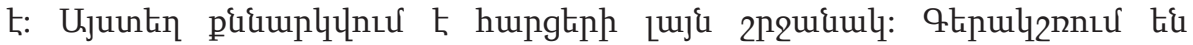

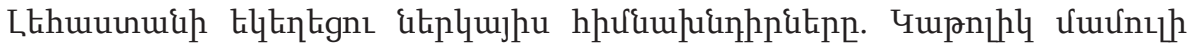

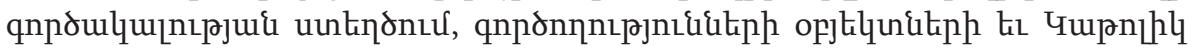

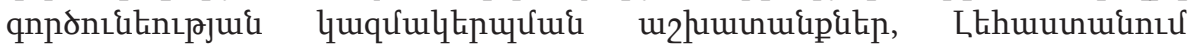

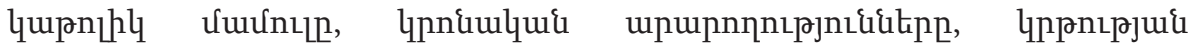

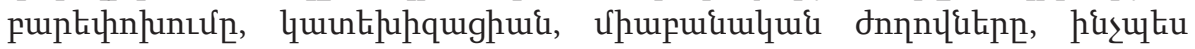

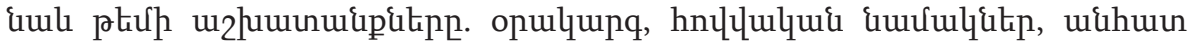

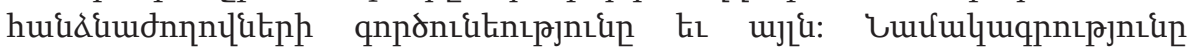

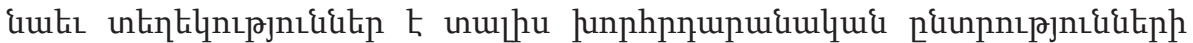

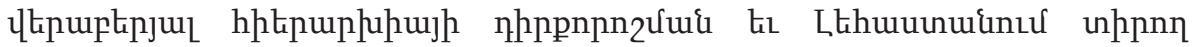

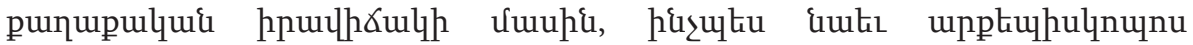

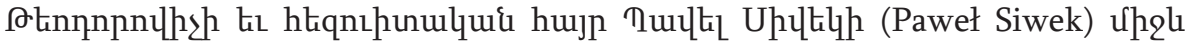

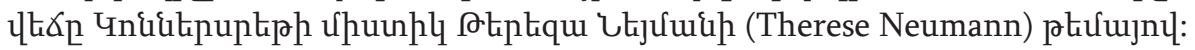

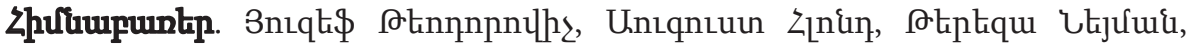
Lthouunuwh qupnily tiltitigh 
Tomasz Krzyżowski, The Correspondence between the Armenian Catholic Archbishop Józef Teodorowicz and the Polish Primate Cardinal August Hlond in the years 1924-1938

Cardinal August Hlond (1881-1948) and Archbishop Józef Teodorowicz (18641938) are notable representatives of the Polish Episcopate of the first half of the 20th century. They were men of extraordinary abilities, spiritual and intellectual values and organizational skills. As devout shepherds and great patriots, they took an active part in public life. Their letters, which constitute the main subject of this edit, illustrate the comprehensive and multi-layered involvement of both hierarchs in the area of Church and state, as well as their intense mutual cooperation. The article raises a number of issues, mainly concerning the problems of the Catholic Church in Poland at that time, i.e. the establishment of the Catholic News Agency, the work to create the facilities of the Catholic Action and their activities, the Catholic press in Poland, religious ceremonies, the education reform, catechisation, religious congregations, and the work of the episcopacy: the agenda, pastoral letters, activities of individual committees, etc. In addition, the letters provide information on the position of the two hierarchs on the parliamentary elections and the political situation in Poland, and also on the dispute between Archbishop Teodorowicz and the Jesuit Pawer Siwek about the Catholic mystic Therese Neumann of Konnersreuth.

Keywords: Józef Teodorowicz, August Hlond, Therese Neumann, Catholic Church in Poland 